Highly Stereo- and Regioselective Hydrocarboxylation of Diynes with

\title{
Carbon Dioxide
}

Tao Cao, ${ }^{a}$ and Shengming $\mathrm{Ma}^{* a, b}$

${ }^{a}$ State Key Laboratory of Organometallic Chemistry, Shanghai Institute of Organic Chemistry, Chinese Academy of Sciences, 345 Lingling Lu, Shanghai 200032, P. R. China

${ }^{b}$ Department of Chemistry, Fudan University, 220 Handan Lu, Shanghai 200433, P. R. China

Email: $\underline{\text { masm@, sioc.ac.cn }}$

\section{Supporting Information}

Index

1. Typical Procedure and Analytical Data for Compounds S2

2. References S34

3. ${ }^{1} \mathrm{H}$ NMR,,${ }^{13} \mathrm{C}$ NMR, ${ }^{19} \mathrm{~F}$ NMR and NOE Spectra $\quad$ S36 
General Information: All reactions were carried out in oven dried Schlenk tubes. $\mathrm{Ni}(\operatorname{cod})_{2}$ was purchased from Strem Chemicals and kept in a glove box at $-30{ }^{\circ} \mathrm{C}$. $\mathrm{ZnEt}_{2}$ was purchased from $\mathrm{J} \& \mathrm{~K}$ Scientific. CsF was purchased from Acros. $\mathrm{MeOH}$ was dried over magnesium turning before distillation. THF was dried over sodium before distillation. $\mathrm{CH}_{3} \mathrm{CN}$, DMSO, and DMF were dried over calcium hydride before distillation. Other reagents were used without further treatment. All the temperatures are referred to the oil baths used. $\mathrm{CFCl}_{3}$ was used as the internal standard for the ${ }^{19} \mathrm{~F}$ NMR analysis.

\section{Preparation of starting materials.}

The starting materials $\mathbf{1 a},{ }^{1} \mathbf{1 b},{ }^{2} \mathbf{1 d},{ }^{3} \mathbf{1 e},{ }^{1} \mathbf{1 f},{ }^{4} \mathbf{1 g},{ }^{5} \mathbf{1 h},{ }^{5} \mathbf{1 i},{ }^{6} \mathbf{1 q}{ }^{1}$, and $\mathbf{6}^{7}$ were prepared according to literatures.

(1) Preparation of dimethyl 2,2-di(2-heptynyl)malonate (1c) (ct-4-151)

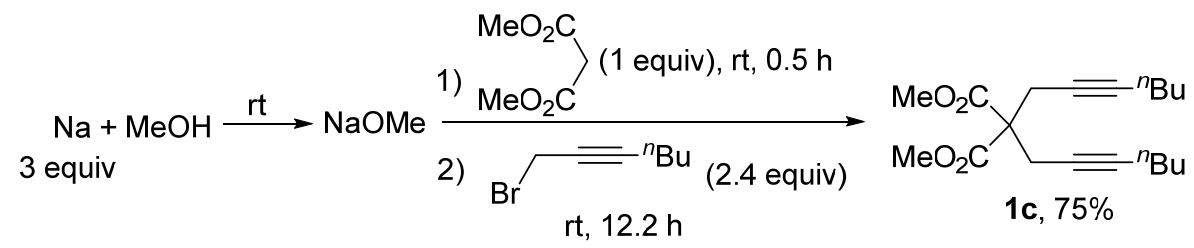

Under Ar atmosphere, to a $50 \mathrm{~mL}$ three-neck flask equipped with a reflux condenser were added $\mathrm{Na}(0.6927 \mathrm{~g}, 30 \mathrm{mmol})$ and $30 \mathrm{~mL}$ of $\mathrm{MeOH}$. After the reaction was complete, to the solution was added dimethyl malonate $(1.2 \mathrm{~mL}, \mathrm{~d}=$ $1.15 \mathrm{~g} / \mathrm{mL}, 1.38 \mathrm{~g}, 10 \mathrm{mmol})$. After being stirred for $0.5 \mathrm{~h}$ at room temperature, to the mixture was dropwise added 2-heptynyl bromide $(3.4 \mathrm{~mL}, \mathrm{~d}=1.22 \mathrm{~g} / \mathrm{mL}, 4.148 \mathrm{~g}$, $23.7 \mathrm{mmol}$ ) within $10 \mathrm{~min}$. After being stirred at room temperature for additional 12.2 $\mathrm{h}$, the mixture was concentrated in vacuo to remove $\mathrm{MeOH}$. To the mixture was added water $(20 \mathrm{~mL})$. The aqueous layer was extracted with $\mathrm{Et}_{2} \mathrm{O}(20 \mathrm{~mL} \times 3)$. The combined organic layer was washed with brine $(30 \mathrm{~mL})$, dried over anhydrous $\mathrm{MgSO}_{4}$, filtered and concentrated in vacuo to afford 1c $(2.4032 \mathrm{~g}, 75 \%)$ via column chromatography on silica gel (eluent: petroleum ether/ ethyl acetate $=40 / 1$ ) as an oil: ${ }^{1} \mathrm{H}$ NMR (400 MHz, $\left.\mathrm{CDCl}_{3}\right) \delta 3.73\left(\mathrm{~s}, 6 \mathrm{H}, \mathrm{OCH}_{3} \times 2\right), 2.91\left(\mathrm{~s}, 4 \mathrm{H}, \mathrm{CH}_{2} \times 2\right), 2.12(\mathrm{t}$, $\left.J=6.6 \mathrm{~Hz}, 4 \mathrm{H}, \mathrm{CH}_{2} \times 2\right), 1.48-1.32\left(\mathrm{~m}, 8 \mathrm{H}, \mathrm{CH}_{2} \times 4\right), 0.89\left(\mathrm{t}, J=7.0 \mathrm{~Hz}, 6 \mathrm{H}, \mathrm{CH}_{3}\right.$ 
$\times 2) ;{ }^{13} \mathrm{C} \mathrm{NMR}\left(100 \mathrm{MHz}, \mathrm{CDCl}_{3}\right) \delta$ 169.6, 83.5, 74.0, 57.2, 52.7, 30.8, 22.9, 21.7, 18.2, 13.4; MS (ESI) (m/z) $321\left([\mathrm{M}+\mathrm{H}]^{+}\right)$; IR (neat, $\left.\mathrm{cm}^{-1}\right)$ 2957, 2932, 2868, 1740, $1459,1434,1328,1290,1201,1148,1072,1054$; HRMS calcd for $\mathrm{C}_{19} \mathrm{H}_{29} \mathrm{O}_{4}$ $\left([\mathrm{M}+\mathrm{H}]^{+}\right): 321.2066$; found: 321.2062.

(2) Preparation of dimethyl 2-(2-butynyl)-2-(5-hydroxy-2-pentynyl)malonate (1j) (ct-4-60, ct-4-67)

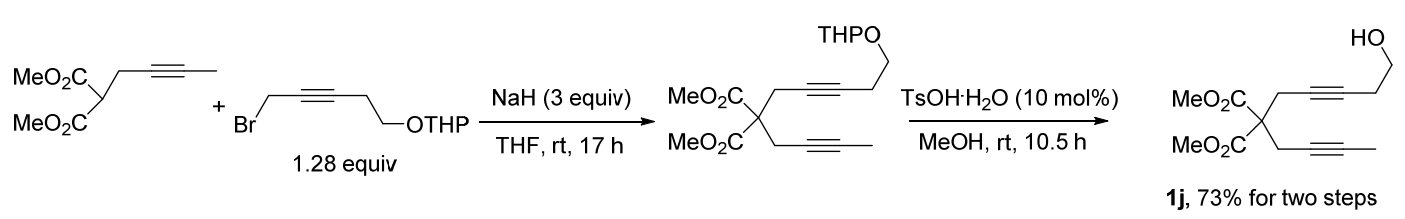

Under Ar atmosphere, to a $50 \mathrm{~mL}$ Schlenk tube were added $\mathrm{NaH}(60 \%$ dispersion in mineral oil, $0.9533 \mathrm{~g}, 23.8 \mathrm{mmol})$, THF $(10 \mathrm{~mL})$, and dimethyl 2-(2-butynyl)malonate (1.3896 g, $7.5 \mathrm{mmol})$ sequentially. After being stirred for 22 min at room temperature, to the mixture were added 2-((5-bromo-3-pentynyl)oxy) tetrahydro-2H-pyran $(2.3677 \mathrm{~g}, 9.6 \mathrm{mmol})$ and $10 \mathrm{~mL}$ of THF. After being stirred for $17 \mathrm{~h}$ at room temperature, the reaction was complete as monitored by TLC. Water (10 $\mathrm{mL}$ ) was added to quench the reaction, and the organic layer was separated. The aqueous layer was extracted with ethyl acetate $(10 \mathrm{~mL} \times 3)$ and the combined organic layer was washed with brine $(10 \mathrm{~mL})$, dried over anhydrous $\mathrm{MgSO}_{4}$, filtered and concentrated in vacuo to afford dimethyl 2-(2-butynyl)-2-(5-((2-tetrahydro-2H-pyranyl)oxy)-2-pentynyl)malonate (2.1015 g) as an oil via column chromatography on silica gel (eluent: petroleum ether/ethyl acetate $=15 / 1)$ and used directly in the next step.

To a round bottom flask were added dimethyl 2-(2-butynyl)-2(5-((2-tetrahydro-2H-pyranyl)oxy)-2-pentynyl)malonate (2.1015 g) prepared above, $\mathrm{MeOH}(20 \mathrm{~mL})$, and $\mathrm{TsOH}^{\circ} \mathrm{H}_{2} \mathrm{O}(113.0 \mathrm{mg}, 0.6 \mathrm{mmol})$. After being stirred at room temperature for $10.5 \mathrm{~h}$, the reaction was complete as monitored by TLC. The mixture was concentrated in vacuo to afford $\mathbf{1 j}$ (1.4738 g, 73\% for two steps) via column chromatography on silica gel (eluent: petroleum ether/ ethyl acetate $=2 / 1$ ) as an oil: ${ }^{1} \mathrm{H}$ NMR $\left(400 \mathrm{MHz}, \mathrm{CDCl}_{3}\right) \delta 3.76\left(\mathrm{~s}, 6 \mathrm{H}, \mathrm{OCH}_{3} \times 2\right), 3.65(\mathrm{t}, J=5.0 \mathrm{~Hz}, 2 \mathrm{H}$, 
$\left.\mathrm{OCH}_{2}\right), 2.92\left(\mathrm{~s}, 2 \mathrm{H}, \mathrm{CH}_{2}\right), 2.89\left(\mathrm{~s}, 2 \mathrm{H}, \mathrm{CH}_{2}\right), 2.68$ (brs, $\left.1 \mathrm{H}, \mathrm{OH}\right), 2.38$ (t, J=5.6 Hz, $\left.2 \mathrm{H}, \mathrm{CH}_{2}\right), 1.75\left(\mathrm{~s}, 3 \mathrm{H}, \mathrm{CH}_{3}\right) ;{ }^{13} \mathrm{C} \mathrm{NMR}\left(100 \mathrm{MHz}, \mathrm{CDCl}_{3}\right) \delta$ 169.7, 80.6, 79.1, 76.2, 72.7, 61.0, 56.9, 52.8, 22.92, 22.89, 22.87, 3.3; MS (ESI) (m/z) $267\left([\mathrm{M}+\mathrm{H}]^{+}\right)$; IR (neat, $\mathrm{cm}^{-1}$ ) 3600-3000, 2956, 2924, 1732, 1435, 1328, 1292, 1247, 1203, 1150, 1119 , 1050; HRMS calcd for $\mathrm{C}_{14} \mathrm{H}_{19} \mathrm{O}_{5}\left([\mathrm{M}+\mathrm{H}]^{+}\right): 267.1232$; found: 267.1228 .

(3) Preparation of dimethyl 2-(2-butynyl)-2-(3-(4-fluorophenyl)-2-propynyl)malonate (1k) (ct-5-90)

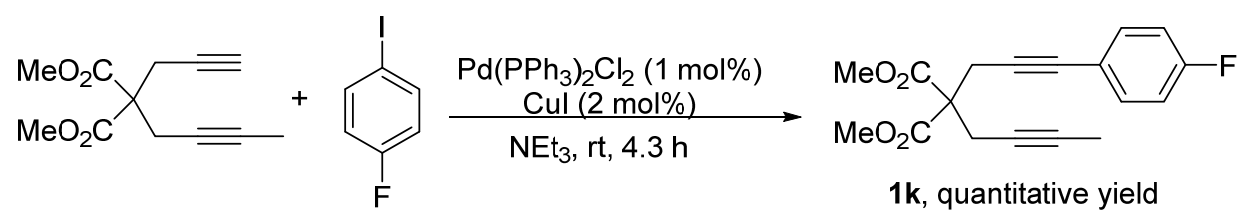

Typical Procedure A: Under Ar atmosphere, to a $50 \mathrm{~mL}$ three-neck flask were $\begin{array}{lllll}\text { added } \quad \operatorname{Pd}\left(\mathrm{PPh}_{3}\right) \mathrm{Cl}_{2} & (0.0351 \quad \mathrm{~g}, \quad 0.05 \quad \mathrm{mmol}), \quad \text { dimethyl }\end{array}$ 2-(2-butynyl)-2-(2-propynyl)malonate (1.0846 g, 4.9 mmol), 1-fluoro-4-iodobenzene (1.1115 g, $5.0 \mathrm{mmol})$, and $20 \mathrm{~mL}$ of $\mathrm{NEt}_{3}$ sequentially. After being stirred for $5 \mathrm{~min}$ at room temperature, to the mixture was added $\mathrm{CuI}(0.0193 \mathrm{~g}, 0.10 \mathrm{mmol})$. After being stirred at room temperature for $4.3 \mathrm{~h}$, the reaction was complete as monitored by TLC. The mixture was filtered and eluted with $20 \mathrm{~mL}$ of ethyl acetate. After being concentrated in vacuo, 1k (1.5940 g, quantitative yield) was obtained via column chromatography on silica gel (eluent: petroleum ether/ethyl acetate $=7 / 1$ ) as an oil: ${ }^{1} \mathrm{H} \mathrm{NMR}\left(400 \mathrm{MHz}, \mathrm{CDCl}_{3}\right) \delta 7.34(\mathrm{t}, J=6.6 \mathrm{~Hz}, 2 \mathrm{H}, \mathrm{ArH}), 6.97(\mathrm{t}, J=8.4 \mathrm{~Hz}, 2 \mathrm{H}$, $\mathrm{ArH}), 3.77\left(\mathrm{~s}, 6 \mathrm{H}, \mathrm{OCH}_{3} \times 2\right), 3.17\left(\mathrm{~s}, 2 \mathrm{H}, \mathrm{CH}_{2}\right), 2.97\left(\mathrm{~s}, 2 \mathrm{H}, \mathrm{CH}_{2}\right), 1.77(\mathrm{~s}, 3 \mathrm{H}$, $\left.\mathrm{CH}_{3}\right) ;{ }^{13} \mathrm{C} \mathrm{NMR}\left(100 \mathrm{MHz}, \mathrm{CDCl}_{3}\right) \delta 169.5,162.3(\mathrm{~d}, J=247.3 \mathrm{~Hz}), 133.5(\mathrm{~d}, J=8.2$ Hz), 119.1 (d, $J=3.3 \mathrm{~Hz}), 115.4$ (d, $J=21.9 \mathrm{~Hz}), 83.7,82.5,79.3,72.9,57.1,53.0$, 23.5, 23.2, 3.5; ${ }^{19} \mathrm{~F}$ NMR $\left(376 \mathrm{MHz}, \mathrm{CDCl}_{3}\right) \delta$-111.9; MS (ESI) $(\mathrm{m} / \mathrm{z}) 317\left([\mathrm{M}+\mathrm{H}]^{+}\right)$; IR (neat, $\mathrm{cm}^{-1}$ ) 1737, 1601, 1506, 1435, 1328, 1292, 1263, 1202, 1154, 1072, 1054 , 1015; HRMS calcd for $\mathrm{C}_{18} \mathrm{H}_{18} \mathrm{FO}_{4}\left([\mathrm{M}+\mathrm{H}]^{+}\right)$: 317.1189 ; found: 317.1186 .

(4) Preparation of dimethyl 2-(2-butynyl)-2-(3-(4-methoxycarbonylphenyl) -2-propynyl) malonate (11) (ct-8-92) 


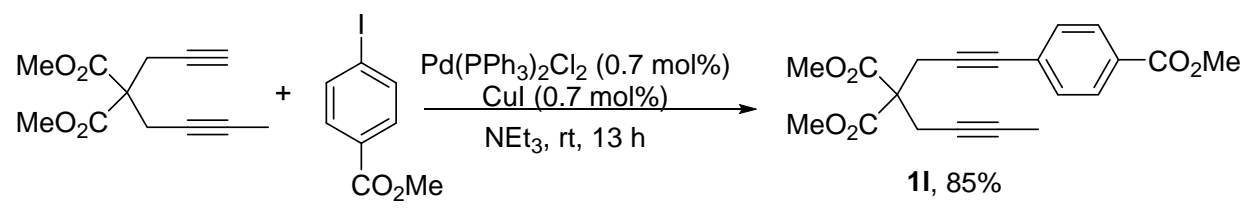

Following Typical Procedure A, the reaction of dimethyl 2-(2-butynyl)-2-(2-propynyl)malonate (597.0 mg, $2.69 \mathrm{mmol})$, methyl 4-iodobenzoate (709.3 mg, $2.71 \mathrm{mmol}), \mathrm{Pd}\left(\mathrm{PPh}_{3}\right)_{2} \mathrm{Cl}_{2}(14.2 \mathrm{mg}, 0.02 \mathrm{mmol})$, and $\mathrm{CuI}(3.9 \mathrm{mg}, 0.02$ mmol) in $10 \mathrm{~mL}$ of $\mathrm{NEt}_{3}$ for $13 \mathrm{~h}$ afforded 11 (809.2 $\left.\mathrm{mg}, 85 \%\right)$ via column chromatography on silica gel (eluent: petroleum ether/ ethyl acetate $=5 / 1$ ) as a solid: m.p. 91.6-92.8 ${ }^{\circ} \mathrm{C}$ (petroleum ether/ethyl acetate); ${ }^{1} \mathrm{H}$ NMR $\left(400 \mathrm{MHz}, \mathrm{CDCl}_{3}\right) \delta 7.95$ $(\mathrm{d}, J=8.0 \mathrm{~Hz}, 2 \mathrm{H}, \mathrm{ArH}), 7.42(\mathrm{~d}, J=8.0 \mathrm{~Hz}, 2 \mathrm{H}, \mathrm{ArH}), 3.91\left(\mathrm{~s}, 3 \mathrm{H}, \mathrm{OCH}_{3}\right), 3.78(\mathrm{~s}$, $\left.6 \mathrm{H}, \mathrm{OCH}_{3} \times 2\right), 3.22\left(\mathrm{~s}, 2 \mathrm{H}, \mathrm{CH}_{2}\right), 2.99\left(\mathrm{~s}, 2 \mathrm{H}, \mathrm{CH}_{2}\right), 1.77\left(\mathrm{~s}, 3 \mathrm{H}, \mathrm{CH}_{3}\right) ;{ }^{13} \mathrm{C} \mathrm{NMR}$ $\left(100 \mathrm{MHz}, \mathrm{CDCl}_{3}\right) \delta 169.3,166.3,131.5,129.23,129.20,127.6,87.3,82.9,79.3$, 72.7, 56.9, 52.9, 52.0, 23.5, 23.1, 3.4; MS (ESI) (m/z) $357\left([\mathrm{M}+\mathrm{H}]^{+}\right)$; IR (neat, $\left.\mathrm{cm}^{-1}\right)$ $1735,1718,1605,1560,1437,1403,1378,1325,1279,1247,1208,1193,1109,1075$, 1054, 1017; Anal. calcd for $\mathrm{C}_{20} \mathrm{H}_{20} \mathrm{O}_{6}(\%)$ : C 67.41, H 5.66; found: C 67.48, H 5.51.

(5) Preparation of dimethyl 2-(2-butynyl)-2-(3-(3-methoxyphenyl)-2-propynyl) malonate (1m) (ct-6-19)

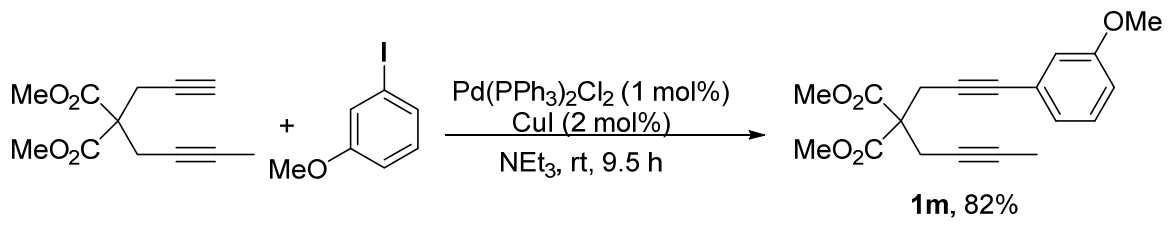

Following Typical Procedure A, the reaction of dimethyl

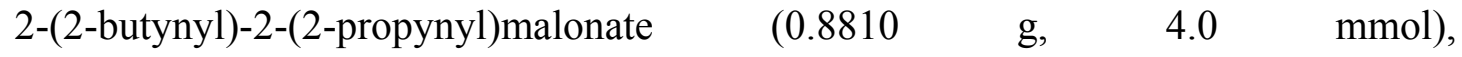
1-iodo-3-methoxybenzene (0.9424 g, $4.0 \mathrm{mmol}), \mathrm{Pd}\left(\mathrm{PPh}_{3}\right)_{2} \mathrm{Cl}_{2}(0.0281 \mathrm{~g}, 0.04 \mathrm{mmol})$,

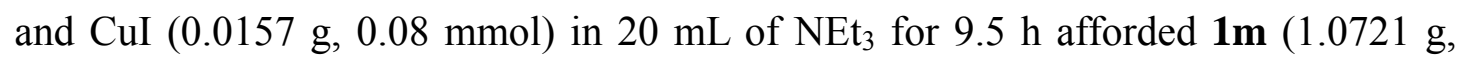
$82 \%$ ) via column chromatography on silica gel (eluent: petroleum ether/ ethyl acetate $=15 / 1)$ as an oil: ${ }^{1} \mathrm{H}$ NMR $\left(400 \mathrm{MHz}, \mathrm{CDCl}_{3}\right) \delta 7.18(\mathrm{t}, J=7.8 \mathrm{~Hz}, 1 \mathrm{H}, \mathrm{ArH}), 6.96$ (d, $J=7.6 \mathrm{~Hz}, 1 \mathrm{H}, \mathrm{ArH}), 6.89$ (s, $1 \mathrm{H}, \mathrm{ArH}), 6.84$ (d, $J=8.4 \mathrm{~Hz}, 1 \mathrm{H}, \mathrm{ArH}), 3.77$ (s, $\left.9 \mathrm{H}, \mathrm{OCH}_{3} \times 3\right), 3.18\left(\mathrm{~s}, 2 \mathrm{H}, \mathrm{CH}_{2}\right), 2.98\left(\mathrm{~s}, 2 \mathrm{H}, \mathrm{CH}_{2}\right), 1.77\left(\mathrm{~s}, 3 \mathrm{H}, \mathrm{CH}_{3}\right) ;{ }^{13} \mathrm{C} \mathrm{NMR}$ $\left(100 \mathrm{MHz}, \mathrm{CDCl}_{3}\right) \delta 169.4,159.1,129.2,124.1,124.0,116.5,114.4,83.8,83.4,79.2$, 
72.9, 57.0, 55.1, 52.9, 23.5, 23.1, 3.4; MS (ESI) (m/z) $329\left([\mathrm{M}+\mathrm{H}]^{+}\right)$; IR (neat, $\left.\mathrm{cm}^{-1}\right)$ $1737,1599,1577,1485,1433,1322,1288,1201,1073,1047,1011$; HRMS calcd for $\mathrm{C}_{19} \mathrm{H}_{24} \mathrm{NO}_{5}\left(\left[\mathrm{M}+\mathrm{NH}_{4}\right]^{+}\right): 346.1654$; found: 346.1650 .

(6) Preparation of dimethyl 2-(2-butynyl)-2-(3-(4-methylphenyl)-2-propynyl)malonate (1n) (ct-6-6)

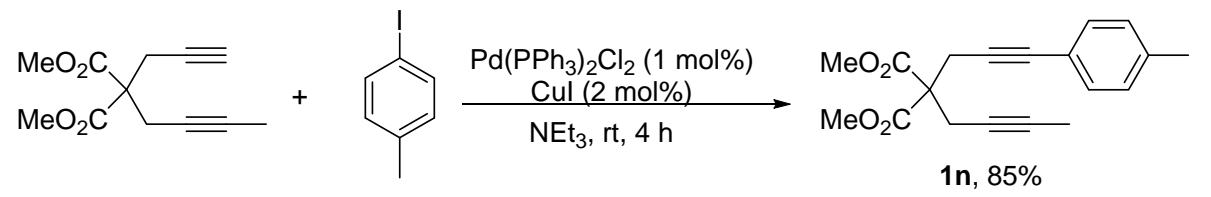

Following Typical Procedure A, the reaction of dimethyl 2-(2-butynyl)-2-(2-propynyl)malonate (0.8886 g, $4.0 \mathrm{mmol})$, 4-iodotoluene (0.8809 g, $4.0 \mathrm{mmol}), \mathrm{Pd}\left(\mathrm{PPh}_{3}\right)_{2} \mathrm{Cl}_{2}(0.0277 \mathrm{~g}, 0.04 \mathrm{mmol})$, and $\mathrm{CuI}(0.0156 \mathrm{~g}, 0.08 \mathrm{mmol})$ in 20 $\mathrm{mL}$ of $\mathrm{NEt}_{3}$ for $4 \mathrm{~h}$ afforded $\mathbf{1 n}(1.0591 \mathrm{~g}, 85 \%)$ via column chromatography on silica gel (eluent: petroleum ether/ ethyl acetate $=10 / 1)$ as an oil: ${ }^{1} \mathrm{H}$ NMR (400 MHz, $\left.\mathrm{CDCl}_{3}\right) \delta 7.25(\mathrm{~d}, J=7.6 \mathrm{~Hz}, 2 \mathrm{H}, \mathrm{ArH}), 7.08(\mathrm{~d}, J=8.0 \mathrm{~Hz}, 2 \mathrm{H}, \mathrm{ArH}), 3.77$ (s, $6 \mathrm{H}$, $\left.\mathrm{OCH}_{3} \times 2\right), 3.17\left(\mathrm{~s}, 2 \mathrm{H}, \mathrm{CH}_{2}\right), 2.98\left(\mathrm{q}, J=2.5 \mathrm{~Hz}, 2 \mathrm{H}, \mathrm{CH}_{2}\right), 2.33\left(\mathrm{~s}, 3 \mathrm{H}, \mathrm{CH}_{3}\right)$, $1.77\left(\mathrm{t}, J=2.6 \mathrm{~Hz}, 3 \mathrm{H}, \mathrm{CH}_{3}\right) ;{ }^{13} \mathrm{C} \mathrm{NMR}\left(100 \mathrm{MHz}, \mathrm{CDCl}_{3}\right) \delta 169.5,138.0,131.4$, 128.8, 119.9, 83.6, 83.1, 79.1, 72.9, 57.1, 52.9, 23.5, 23.1, 21.3, 3.4; MS (ESI) (m/z) $313\left([\mathrm{M}+\mathrm{H}]^{+}\right)$; IR $\left(\right.$neat, $\left.\mathrm{cm}^{-1}\right)$ 1738, 1510, 1435, 1327, 1291, 1202, 1152, 1120, 1073, 1054, 1024; HRMS calcd for $\mathrm{C}_{19} \mathrm{H}_{24} \mathrm{NO}_{4}\left(\left[\mathrm{M}+\mathrm{NH}_{4}\right]^{+}\right)$: 330.1705; found: 330.1702 .

(7) Preparation of dimethyl 2-(2-pentynyl)-2-(3-(4-methoxycarbonylphenyl) -2-propynyl)malonate (10) (ct-6-72)

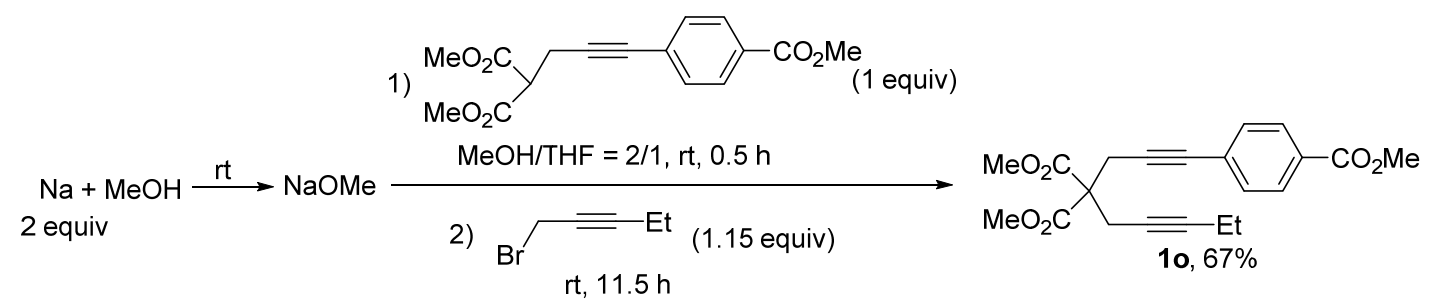

Under Ar atmosphere, to a $100 \mathrm{~mL}$ three-neck flask equipped with a reflux condenser were added $\mathrm{Na}(0.3721 \mathrm{~g}, 16 \mathrm{mmol})$ and $20 \mathrm{~mL}$ of $\mathrm{MeOH}$. After the reaction was complete, to the solution were added dimethyl 
2-(3-(4-methoxycarbonylphenyl)-2-propynyl)malonate (2.4248 g, $8.0 \mathrm{mmol})$ and THF $(10 \mathrm{~mL})$. After being stirred for $0.5 \mathrm{~h}$ at room temperature, to the mixture was added 2-pentynyl bromide $(1.3542 \mathrm{~g}, 9.2 \mathrm{mmol})$. After being stirred for $11.5 \mathrm{~h}$, the mixture was concentrated in vacuo to remove $\mathrm{MeOH}$ and THF. To the mixture was added water $(20 \mathrm{~mL})$. The aqueous layer was extracted with ethyl acetate $(20 \mathrm{~mL} \times 3)$. The combined organic layer was washed with brine $(20 \mathrm{~mL})$, dried over anhydrous $\mathrm{MgSO}_{4}$, filtered and concentrated in vacuo to afford 10 (1.9727 g, 67\%) via column chromatography on silica gel (eluent: petroleum ether/ ethyl acetate $=15 / 1$ ) as an oil: ${ }^{1} \mathrm{H}$ NMR (400 MHz, $\left.\mathrm{CDCl}_{3}\right) \delta 7.95(\mathrm{~d}, J=8.0 \mathrm{~Hz}, 2 \mathrm{H}, \mathrm{ArH}), 7.42(\mathrm{~d}, J=8.4 \mathrm{~Hz}, 2 \mathrm{H}$, ArH), $3.91\left(\mathrm{~s}, 3 \mathrm{H}, \mathrm{OCH}_{3}\right), 3.78\left(\mathrm{~s}, 6 \mathrm{H}, \mathrm{OCH}_{3} \times 2\right), 3.22\left(\mathrm{~s}, 2 \mathrm{H}, \mathrm{CH}_{2}\right), 2.99(\mathrm{~s}, 2 \mathrm{H}$, $\left.\mathrm{CH}_{2}\right), 2.14\left(\mathrm{q}, J=7.5 \mathrm{~Hz}, 2 \mathrm{H}, \mathrm{CH}_{2}\right), 1.10\left(\mathrm{t}, J=7.4 \mathrm{~Hz}, 3 \mathrm{H}, \mathrm{CH}_{3}\right) ;{ }^{13} \mathrm{C} \mathrm{NMR}(100$ $\left.\mathrm{MHz}, \mathrm{CDCl}_{3}\right) \delta 169.3,166.4,131.5,129.30,129.26,127.7,87.4,85.4,82.9,73.1$, 57.1, 53.0, 52.1, 23.6, 23.2, 14.0, 12.3; MS (ESI) (m/z) $371\left([\mathrm{M}+\mathrm{H}]^{+}\right)$; IR (neat, $\left.\mathrm{cm}^{-1}\right)$ $1723,1605,1561,1506,1431,1405,1329,1278,1256,1206,1109$, 1076, 1057, 1015; HRMS calcd for $\mathrm{C}_{21} \mathrm{H}_{26} \mathrm{NO}_{6}\left(\left[\mathrm{M}+\mathrm{NH}_{4}\right]^{+}\right)$: 388.1760 ; found: 388.1755 .

(8) Preparation of tetraethyl 1-(3-methoxyphenyl)-1,7-nonadiyne-4,4,5,5tetracarboxylate (1p) (ct-7-127)

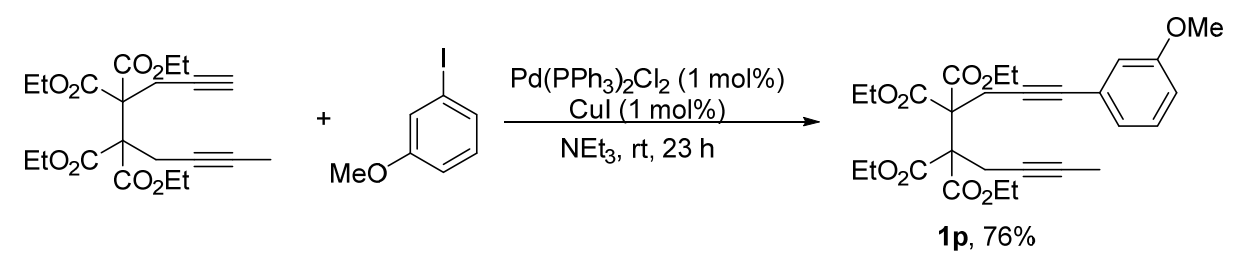

Following Typical Procedure A, the reaction of tetraethyl

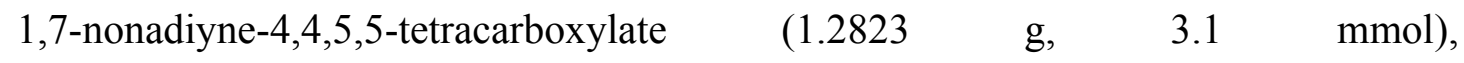
1-iodo-3-methoxybenzene (0.7549 g, $3.1 \mathrm{mmol}), \mathrm{Pd}\left(\mathrm{PPh}_{3}\right)_{2} \mathrm{Cl}_{2}(0.0209 \mathrm{~g}, 0.03 \mathrm{mmol})$, and $\mathrm{CuI}(0.0055 \mathrm{~g}, 0.03 \mathrm{mmol})$ in $10 \mathrm{~mL}^{\text {of }} \mathrm{NEt}_{3}$ for $23 \mathrm{~h}$ afforded $1 \mathbf{p}(1.2294 \mathrm{~g}, 76 \%)$ via column chromatography on silica gel (eluent: petroleum ether/ ethyl acetate $=5 / 1$ ) as an oil: ${ }^{1} \mathrm{H}$ NMR $\left(400 \mathrm{MHz}, \mathrm{CDCl}_{3}\right) \delta 7.17(\mathrm{t}, J=8.0 \mathrm{~Hz}, 1 \mathrm{H}, \mathrm{ArH}), 6.95(\mathrm{~d}, J=$ 7.6 Hz, $1 \mathrm{H}, \mathrm{ArH}), 6.89$ (s, $1 \mathrm{H}, \mathrm{ArH}), 6.83$ (d, J=8.0 Hz, $1 \mathrm{H}, \mathrm{ArH}), 4.33-4.17$ (m, 8 $\left.\mathrm{H}, \mathrm{OCH}_{2} \times 4\right), 3.77\left(\mathrm{~s}, 3 \mathrm{H}, \mathrm{OCH}_{3}\right), 3.40\left(\mathrm{~s}, 2 \mathrm{H}, \mathrm{CH}_{2}\right), 3.12\left(\mathrm{~s}, 2 \mathrm{H}, \mathrm{CH}_{2}\right), 1.75(\mathrm{~s}, 3$ 
$\left.\mathrm{H}, \mathrm{CH}_{3}\right), 1.29\left(\mathrm{t}, J=7.0 \mathrm{~Hz}, 12 \mathrm{H}, \mathrm{CH}_{3} \times 4\right) ;{ }^{13} \mathrm{C} \mathrm{NMR}\left(100 \mathrm{MHz}, \mathrm{CDCl}_{3}\right) \delta 168.7$, $168.6,159.1,129.1,124.5,124.0,116.3,114.2,85.7,82.4,78.2,74.5,61.9,61.79$, 61.78, 61.5, 55.1, 23.2, 22.8, 13.8, 13.7, 3.6; MS (ESI) (m/z) $515\left([\mathrm{M}+\mathrm{H}]^{+}\right)$; IR (neat, $\left.\mathrm{cm}^{-1}\right) 1728,1600,1576,1466,1447,1423,1389,1367,1287,1255,1231,1201,1094$ 1035; HRMS calcd for $\mathrm{C}_{28} \mathrm{H}_{35} \mathrm{O}_{9}\left([\mathrm{M}+\mathrm{H}]^{+}\right)$: 515.2281; found: 515.2277.

(9) Preparation of dimethyl 2-butyl-2-(2-butynyl)malonate (9) (ct-7-80)

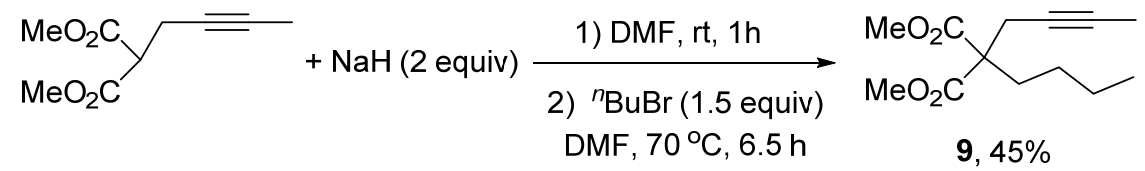

Under $\mathrm{Ar}$ atmosphere, to a $50 \mathrm{~mL}$ Schlenk tube were added $\mathrm{NaH}(60 \%$ dispersion in mineral oil, $0.4142 \mathrm{~g}, 10 \mathrm{mmol})$, DMF (5 mL), and dimethyl 2-(2-butynyl)malonate $(0.9125 \mathrm{~g}, 5.0 \mathrm{mmol})$ sequentially. After being stirred for $1 \mathrm{~h}$ at room temperature, to the mixture was added a solution of butyl bromide $(0.8 \mathrm{~mL}, \mathrm{~d}$ $=1.27 \mathrm{~g} / \mathrm{mL}, 1.016 \mathrm{~g}, 7.4 \mathrm{mmol})$ in $5 \mathrm{~mL}$ of DMF. Then the Schlenk tube was placed in an oil bath pre-heated at $70{ }^{\circ} \mathrm{C}$. After being stirred for $6.5 \mathrm{~h}$, brine $(20 \mathrm{~mL})$ was added to quench the reaction. The aqueous layer was extracted with $\mathrm{Et}_{2} \mathrm{O}(10 \mathrm{~mL} \times 3)$. The combined organic layer was washed with brine $(10 \mathrm{~mL})$, dried over anhydrous $\mathrm{MgSO}_{4}$, filtered and concentrated in vacuo to afford $9(0.5400 \mathrm{~g}, 45 \%)$ via column chromatography on silica gel (eluent: petroleum ether/ diethyl ether $=10 / 1$ ) as an oil: ${ }^{1} \mathrm{H}$ NMR (400 MHz, $\left.\mathrm{CDCl}_{3}\right) \delta 3.73\left(\mathrm{~s}, 6 \mathrm{H}, \mathrm{CH}_{3} \times 2\right), 2.76\left(\mathrm{~s}, 2 \mathrm{H}, \mathrm{CH}_{2}\right), 2.07-1.96$ (m, $\left.2 \mathrm{H}, \mathrm{CH}_{2}\right), 1.75$ (s, $\left.3 \mathrm{H}, \mathrm{CH}_{3}\right), 1.40-1.29$ (m, $\left.2 \mathrm{H}, \mathrm{CH}_{2}\right), 1.18-1.06\left(\mathrm{~m}, 2 \mathrm{H}, \mathrm{CH}_{2}\right)$, $0.91\left(\mathrm{t}, J=7.2 \mathrm{~Hz}, 3 \mathrm{H}, \mathrm{CH}_{3}\right) ;{ }^{13} \mathrm{C} \mathrm{NMR}\left(100 \mathrm{MHz}, \mathrm{CDCl}_{3}\right) \delta 171.1,78.5,73.2,57.1$, 52.5, 31.6, 26.0, 23.0, 22.8, 13.8, 3.4; MS (ESI) (m/z) $241\left([\mathrm{M}+\mathrm{H}]^{+}\right)$; IR (neat, $\left.\mathrm{cm}^{-1}\right)$ 2957, 2931, 2866, 2236, 1734, 1437, 1272, 1240, 1201, 1126, 1051, 1026; HRMS calcd for $\mathrm{C}_{13} \mathrm{H}_{20} \mathrm{NaO}_{4}\left([\mathrm{M}+\mathrm{Na}]^{+}\right)$: 263.1259; found: 263.1255 .

\section{2. $\mathrm{Ni}(\operatorname{cod})_{2}$-catalyzed reaction of 1 with carbon dioxide and $\mathbf{Z n E t}_{2}$.}

(1) Preparation of (Z)-2-((E)-2-ethylidene-4,4-bis(methoxycarbonyl)cyclopentylidene) propanoic acid $[(Z, E)-2 a]($ ct-5-32) 


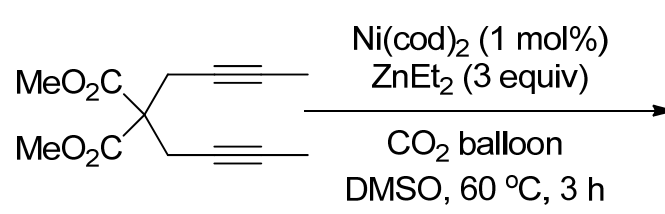

$1 \mathrm{a}$

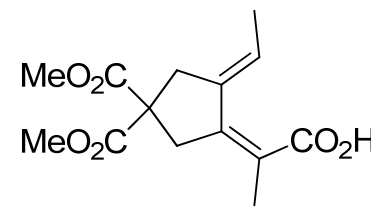

$(Z, E)-\mathbf{2 a}$

NMR yield: $\quad 90 \%$

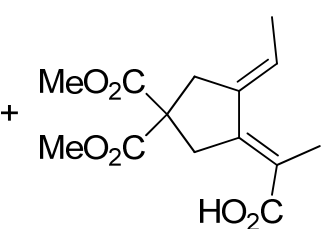

$(E, E)-\mathbf{2 a}$

To a $50 \mathrm{~mL}$ flame-dried Schlenk tube was added $\mathrm{Ni}(\operatorname{cod})_{2}(2.8 \mathrm{mg}, 0.01 \mathrm{mmol})$ inside a glove box. Compound 1a $(236.5 \mathrm{mg}, 1.00 \mathrm{mmol})$ and DMSO $(10 \mathrm{~mL})$ were sequentially added under argon outside the glove box. The Schlenk tube was then frozen with a liquid nitrogen bath. The argon inside the tube was completely replaced with $\mathrm{CO}_{2}$ by using a balloon of $\mathrm{CO}_{2}$ (about $1 \mathrm{~L}$ ). The Schlenk tube was allowed to stand until the temperature was above $0{ }^{\circ} \mathrm{C}$. Then the Schlenck tube was placed in an oil bath pre-heated at $60{ }^{\circ} \mathrm{C}$. After completely thawed, to the mixture was added $\mathrm{ZnEt}_{2}$ (1.5 $\mathrm{M}$ in toluene, $2.0 \mathrm{~mL}, 3.0 \mathrm{mmol}$ ) with a syringe. After being vigorously stirred for $3 \mathrm{~h}$, the reaction was complete as monitored by TLC. $3 \mathrm{M} \mathrm{HCl}(5 \mathrm{~mL})$ was added to quench the reaction. The aqueous layer was extracted with EtOAc $(5 \mathrm{~mL} \times 3)$ and the combined organic layer was washed with brine $(10 \mathrm{~mL})$, dried over anhydrous $\mathrm{MgSO}_{4}$, filtered and concentrated in vacuo. The ratio of $(Z, E)-\mathbf{2 a} /(E, E)-\mathbf{2 a}$ was determined by ${ }^{1} \mathrm{H}$ NMR analysis of the crude product to be 97:3. Pure $(Z, E)-2 \mathbf{a}(177.7$ mg, 63\%) was obtained via column chromatography on silica gel (eluent: petroleum ether/ethyl acetate $=5 / 1$ for the first round; the impure part was submitted to the second round under the same eluent) as a white solid: m.p. $107-108{ }^{\circ} \mathrm{C}$ (petroleum ether/ethyl acetate); ${ }^{1} \mathrm{H}$ NMR (400 MHz, $\left.\mathrm{CDCl}_{3}\right) \delta 10.40$ (s, $\left.1 \mathrm{H}, \mathrm{COOH}\right), 6.14$ (q, $J=$ $6.9 \mathrm{~Hz}, 1 \mathrm{H}, \mathrm{CH}=), 3.75\left(\mathrm{~s}, 6 \mathrm{H}, \mathrm{OCH}_{3} \times 2\right), 3.06\left(\mathrm{~s}, 2 \mathrm{H}, \mathrm{CH}_{2}\right), 3.03\left(\mathrm{~s}, 2 \mathrm{H}, \mathrm{CH}_{2}\right)$, $1.95\left(\mathrm{~s}, 3 \mathrm{H},=\mathrm{C}(\mathrm{CO}) \mathrm{CH}_{3}\right), 1.74\left(\mathrm{~d}, J=7.2 \mathrm{~Hz}, 3 \mathrm{H}, \mathrm{CH}_{3}\right) ;{ }^{13} \mathrm{C} \mathrm{NMR}(100 \mathrm{MHz}$, $\left.\mathrm{CDCl}_{3}\right) \delta 175.5,171.6,143.8,134.9,125.4,119.1,56.3,53.0,39.9,37.5,18.0,15.5$ MS (EI) (m/z) $282\left(\mathrm{M}^{+}, 84.30\right), 267$ (100); IR (neat, $\mathrm{cm}^{-1}$ ) 2955, 2919, 2851, 2628, $1732,1678,1437,1406,1382,1290,1254,1201,1159,1105,1057$; Anal. calcd for $\mathrm{C}_{14} \mathrm{H}_{18} \mathrm{O}_{6}(\%)$ : C 59.57, H 6.43; found: C 59.53, H 6.45.

ORTEP representation of $(Z, E)-\mathbf{2 a}$ : 


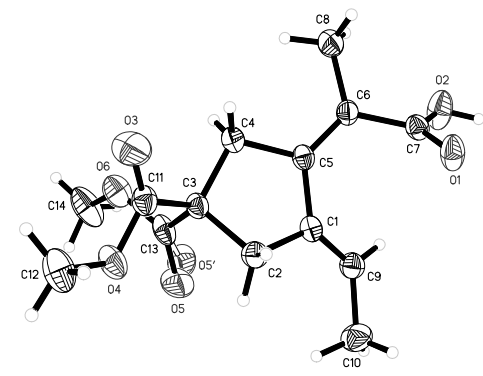

Crystal data for compound $(Z, E)-2 \mathrm{a}: \mathrm{C}_{14} \mathrm{H}_{18} \mathrm{O}_{6}, \mathrm{MW}=282.28$, monoclinic, space group $P 2(1) / c$, final $R$ indices $[I>2 \sigma(I)], R 1=0.0586, w R 2=0.1381 ; R$ indices (all data), $R 1=0.1064, w R 2=0.1629 ; a=6.2663(10) \AA, b=14.1771(19) \AA, c=16.226(3)$ $\AA, \alpha=90.00^{\circ}, \beta=97.633(4)^{\circ}, \gamma=90.00^{\circ}, V=1428.7(4) \AA^{3}, T=293(2) \mathrm{K}, Z=4$, reflections collected/unique 8212/2655 $($ Rint $=0.0540)$, number of observations [ $>$ $2 \sigma(I)]$ 2655, parameters: 198. Supplementary crystallographic data have been deposited at the Cambridge Crystallographic Data Centre, CCDC 1005262.

(2) Preparation of methyl (Z)-2-((E)-2-ethylidene-4,4-bis(methoxycarbonyl) cyclopentylidene)propanoate $[(Z, E)-3 a](\mathrm{ct}-2-168)$

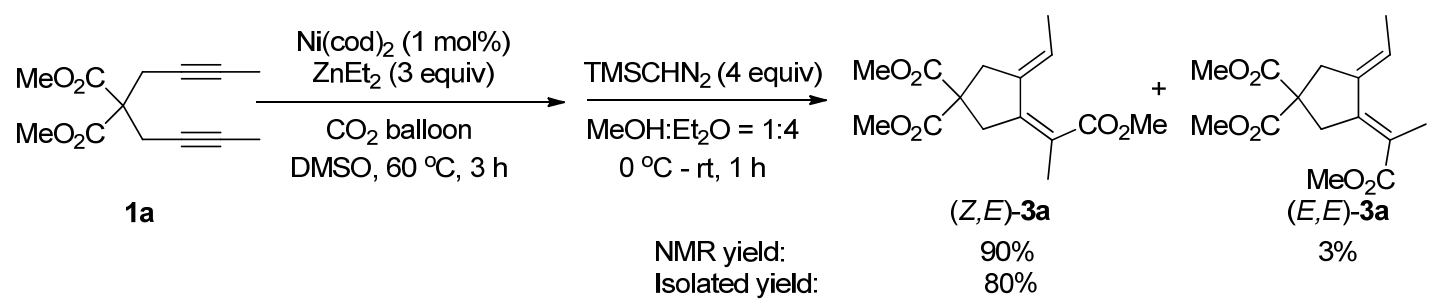

Typical procedure: To a $50 \mathrm{~mL}$ flame-dried Schlenk tube was added $\mathrm{Ni}(\operatorname{cod})_{2}$ (2.7 mg, $0.01 \mathrm{mmol})$ inside a glove box. Compound 1a (236.8 mg, $1.00 \mathrm{mmol})$ and DMSO $(10 \mathrm{~mL})$ were sequentially added under argon outside the glove box. The Schlenk tube was then frozen with a liquid nitrogen bath. The argon inside the tube was completely replaced with $\mathrm{CO}_{2}$ by using a balloon of $\mathrm{CO}_{2}$ (about $1 \mathrm{~L}$ ). The Schlenk tube was allowed to stand until the temperature was above $0{ }^{\circ} \mathrm{C}$. Then the Schlenk tube was placed in an oil bath pre-heated at $60{ }^{\circ} \mathrm{C}$. After completely thawed, to the mixture was added $\mathrm{ZnEt}_{2}(1.5 \mathrm{M}$ in toluene, $2.0 \mathrm{~mL}, 3.0 \mathrm{mmol})$ with a syringe. After being vigorously stirred for $3 \mathrm{~h}$, the reaction was complete as monitored by TLC. $3 \mathrm{M} \mathrm{HCl}(5 \mathrm{~mL})$ was added to quench the reaction. The aqueous layer was extracted 
with EtOAc $(5 \mathrm{~mL} \times 3)$ and the combined organic layer was washed with brine $(10$ $\mathrm{mL}$ ), dried over anhydrous $\mathrm{MgSO}_{4}$, filtered and concentrated in vacuo. To the crude product were added $\mathrm{MeOH}(1 \mathrm{~mL})$ and $\mathrm{Et}_{2} \mathrm{O}(4 \mathrm{~mL})$ and the flask containing the mixture was placed in an ice bath. To the resulting mixture was dropwise added $\mathrm{TMSCHN}_{2}(2.0 \mathrm{M}$ in hexane, $2.0 \mathrm{~mL}, 4.0 \mathrm{mmol})$ with a syringe. After being stirred for $1 \mathrm{~h}$ at room temperature, the reaction was complete as monitored by TLC. The reaction mixture was concentrated and the ratio of $(Z, E)-3 \mathbf{a} /(E, E)-3 \mathbf{a}$ was determined by ${ }^{1} \mathrm{H}$ NMR analysis of the crude product to be $97: 3$. Pure $(Z, E)-3 a(238.7 \mathrm{mg}, 80 \%)$ and impure 3a $(18.5 \mathrm{mg},(Z, E)-3 \mathbf{a} /(E, E)$-3a $=1: 2)$ were obtained via column chromatography on silica gel (eluent: hexane/diethyl ether $=10 / 1$ ) as an oil: ${ }^{1} \mathrm{H}$ NMR $\left(400 \mathrm{MHz}, \mathrm{CDCl}_{3}\right) \delta 5.79(\mathrm{q}, J=7.1 \mathrm{~Hz}, 1 \mathrm{H}, \mathrm{CH}=), 3.74\left(\mathrm{~s}, 6 \mathrm{H}, \mathrm{OCH}_{3} \times 2\right), 3.72(\mathrm{~s}$, $\left.3 \mathrm{H}, \mathrm{OCH}_{3}\right), 3.03\left(\mathrm{~s}, 2 \mathrm{H}, \mathrm{CH}_{2}\right), 3.01\left(\mathrm{~s}, 2 \mathrm{H}, \mathrm{CH}_{2}\right), 1.91\left(\mathrm{~s}, 3 \mathrm{H}, \mathrm{CH}_{3}\right), 1.72(\mathrm{~d}, J=6.8$ $\left.\mathrm{Hz}, 3 \mathrm{H}, \mathrm{CH}_{3}\right) ;{ }^{13} \mathrm{C} \mathrm{NMR}\left(100 \mathrm{MHz}, \mathrm{CDCl}_{3}\right) \delta 171.6,171.2,139.9,135.3,122.8$, 120.0, 56.5, 52.9, 51.6, 39.2, 37.5, 18.0, 15.4; MS (EI) (m/z) $296\left(\mathrm{M}^{+}, 38.40\right), 205$ (100); IR (neat, $\mathrm{cm}^{-1}$ ) 2996, 2954, 2920, 2858, 1736, 1658, 1434, 1379, 1290, 1257, 1204, 1153, 1102, 1063; HRMS calcd for $\mathrm{C}_{15} \mathrm{H}_{20} \mathrm{O}_{6}\left(\mathrm{M}^{+}\right)$: 296.1260; found: 296.1261.

(3) Preparation of methyl (Z)-2-((E)-2-propylidene-4,4-bis(methoxycarbonyl) cyclopentylidene)butanoate $[(Z, E)-3 \mathbf{b}]($ ct-5-54)

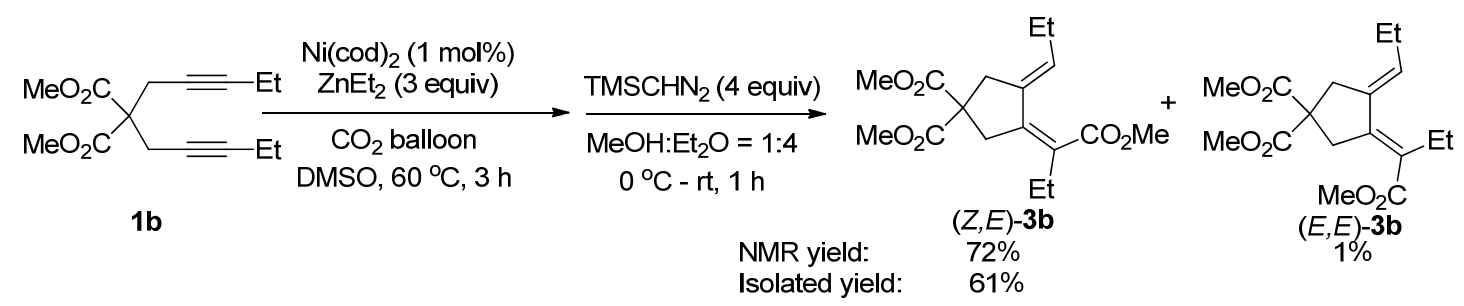

Following Typical Procedure: The reaction of $\mathrm{Ni}(\operatorname{cod})_{2}(2.8 \mathrm{mg}, 0.01 \mathrm{mmol})$, $1 \mathbf{b}$ (purity of $93 \%, 283.6 \mathrm{mg}, 1.00 \mathrm{mmol}), \mathrm{ZnEt}_{2}(1.5 \mathrm{M}$ in toluene, $2.0 \mathrm{~mL}, 3.0$ mmol), and carbon dioxide (about $1 \mathrm{~L}$ ) in $10 \mathrm{~mL}$ of DMSO for $3 \mathrm{~h}$ afforded the crude product. The crude product was then reacted with $\mathrm{TMSCHN}_{2}(2.0 \mathrm{M}$ in hexane, 2.0 $\mathrm{mL}, 4.0 \mathrm{mmol})$ in $1 \mathrm{~mL}$ of $\mathrm{MeOH}$ and $4 \mathrm{~mL}$ of $\mathrm{Et}_{2} \mathrm{O}$ afforded $(Z, E)-3 \mathbf{b}$ with the ratio of $(Z, E)-3 \mathbf{b} /(E, E)$-3b determined by ${ }^{1} \mathrm{H}$ NMR analysis of the crude product to be $99: 1$. Pure $(Z, E)-3 \mathbf{b}(197.4 \mathrm{mg}, 61 \%)$ was obtained via column chromatography on silica 
gel (eluent: hexane/ethyl acetate $=20 / 1)$ as an oil: ${ }^{1} \mathrm{H}$ NMR $\left(400 \mathrm{MHz}, \mathrm{CDCl}_{3}\right) \delta 5.59$ (t, $J=7.4 \mathrm{~Hz}, 1 \mathrm{H}, \mathrm{CH}=), 3.74\left(\mathrm{~s}, 6 \mathrm{H}, \mathrm{OCH}_{3} \times 2\right), 3.71\left(\mathrm{~s}, 3 \mathrm{H}, \mathrm{OCH}_{3}\right), 3.04(\mathrm{~s}, 2 \mathrm{H}$, $\mathrm{CH}_{2}$ ), 3.00 (s, $2 \mathrm{H}, \mathrm{CH}_{2}$ ), 2.29 (q, $2 \mathrm{H}, J=7.5 \mathrm{~Hz}, \mathrm{CH}_{2}$ ), 2.13-2.02 (m, $2 \mathrm{H}, \mathrm{CH}_{2}$ ), $1.04\left(\mathrm{t}, J=7.4 \mathrm{~Hz}, 3 \mathrm{H}, \mathrm{CH}_{3}\right), 0.97$ (t, $\left.J=7.6 \mathrm{~Hz}, 3 \mathrm{H}, \mathrm{CH}_{3}\right) ;{ }^{13} \mathrm{C}$ NMR $(100 \mathrm{MHz}$, $\left.\mathrm{CDCl}_{3}\right) \delta 171.6,171.3,138.0,134.1,129.4,126.7,56.7,52.9,51.6,38.2,37.4,25.7$, 23.2, 13.6, 12.2; MS (EI) (m/z) $324\left(\mathrm{M}^{+}, 24.17\right), 279$ (100); IR (neat, $\left.\mathrm{cm}^{-1}\right)$ 2958, $2876,1733,1434,1245,1202,1156,1115,1068,1014$; HRMS calcd for $\mathrm{C}_{17} \mathrm{H}_{24} \mathrm{O}_{6}$ $\left(\mathrm{M}^{+}\right)$: 324.1573; found: 324.1571 .

(4) Preparation of methyl (Z)-2-((E)-2-pentylidene-4,4-bis(methoxycarbonyl) cyclopentylidene)pentanoate $[(Z, E)-3 c]($ ct-5-53)

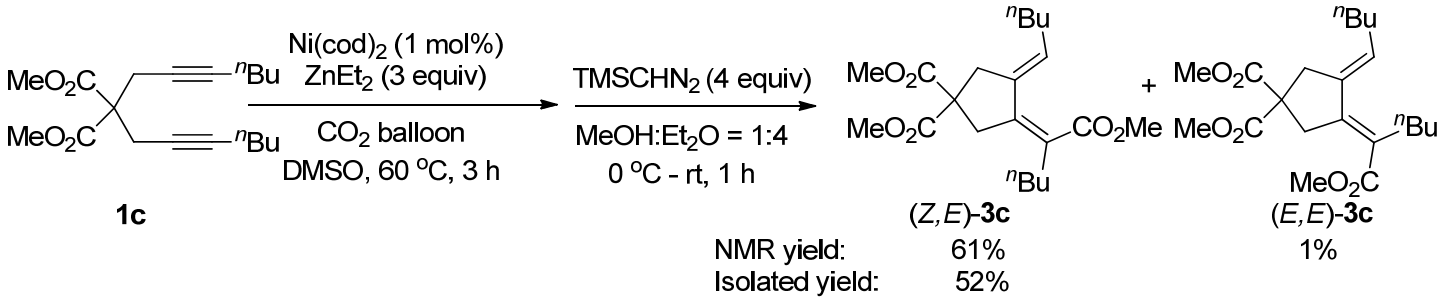

Following Typical Procedure: The reaction of $\mathrm{Ni}(\operatorname{cod})_{2}(2.8 \mathrm{mg}, 0.01 \mathrm{mmol})$, 1c $(319.9 \mathrm{mg}, 1.00 \mathrm{mmol}), \mathrm{ZnEt}_{2}(1.5 \mathrm{M}$ in toluene, $2.0 \mathrm{~mL}, 3.0 \mathrm{mmol})$, and carbon dioxide (about $1 \mathrm{~L}$ ) in $10 \mathrm{~mL}$ of DMSO for $3 \mathrm{~h}$ afforded the crude product. The crude product was then reacted with $\mathrm{TMSCHN}_{2}(2.0 \mathrm{M}$ in hexane, $2.0 \mathrm{~mL}, 4.0 \mathrm{mmol})$ in 1 $\mathrm{mL}$ of $\mathrm{MeOH}$ and $4 \mathrm{~mL}$ of $\mathrm{Et}_{2} \mathrm{O}$ afforded $(Z, E)-3 \mathbf{c}$ with the ratio of $(Z, E)-3 \mathbf{c} /(E, E)-3 \mathbf{c}$ determined by ${ }^{1} \mathrm{H}$ NMR analysis of the crude product to be $98: 2$. $12 \%$ of the protonolysis product was also observed in the crude product. Pure $(Z, E)-3 c$ (196.2 $\mathrm{mg}$, $52 \%$ ) was obtained via column chromatography on silica gel (eluent: hexane/ethyl acetate $=45 / 1$ for the first round; the impure part was submitted to the second round under the same eluent) as an oil: ${ }^{1} \mathrm{H}$ NMR $\left(400 \mathrm{MHz}, \mathrm{CDCl}_{3}\right) \delta 5.57(\mathrm{t}, J=7.4 \mathrm{~Hz}, 1$ $\mathrm{H}, \mathrm{CH}=), 3.74\left(\mathrm{~s}, 6 \mathrm{H}, \mathrm{OCH}_{3} \times 2\right), 3.70\left(\mathrm{~s}, 3 \mathrm{H}, \mathrm{OCH}_{3}\right), 3.04\left(\mathrm{~s}, 2 \mathrm{H}, \mathrm{CH}_{2}\right), 3.00(\mathrm{~s}, 2$ $\left.\mathrm{H}, \mathrm{CH}_{2}\right), 2.26$ (t, $\left.J=7.4 \mathrm{~Hz}, 2 \mathrm{H}, \mathrm{CH}_{2}\right), 2.06$ (q, $\left.J=6.7 \mathrm{~Hz}, 2 \mathrm{H}, \mathrm{CH}_{2}\right), 1.44-1.24(\mathrm{~m}$, $\left.8 \mathrm{H}, \mathrm{CH}_{2} \times 4\right), 0.95-0.84\left(\mathrm{~m}, 6 \mathrm{H}, \mathrm{CH}_{3} \times 2\right) ;{ }^{13} \mathrm{C} \mathrm{NMR}\left(100 \mathrm{MHz}, \mathrm{CDCl}_{3}\right) \delta$ 171.6, $138.2,134.5,127.9,125.6,56.7,52.9,51.6,38.4,37.5,32.3,31.3,29.8,29.6,22.4$, 22.2, 13.9; MS (EI) (m/z) $380\left(\mathrm{M}^{+}, 10.88\right), 323$ (100); IR (neat, $\left.\mathrm{cm}^{-1}\right)$ 2955, 2929, 
2864, 1735, 1656, 1433, 1379, 1251, 1200, 1154, 1117, 1064, 1015; HRMS calcd for $\mathrm{C}_{21} \mathrm{H}_{32} \mathrm{O}_{6}\left(\mathrm{M}^{+}\right)$: 380.2199 ; found: 380.2198 .

(5) Preparation of methyl (E)-2-((Z)-4-ethylidene-1-tosylpyrrolidin3-ylidene)propanoate $[(E, Z)-3 d]($ ct-3-34)

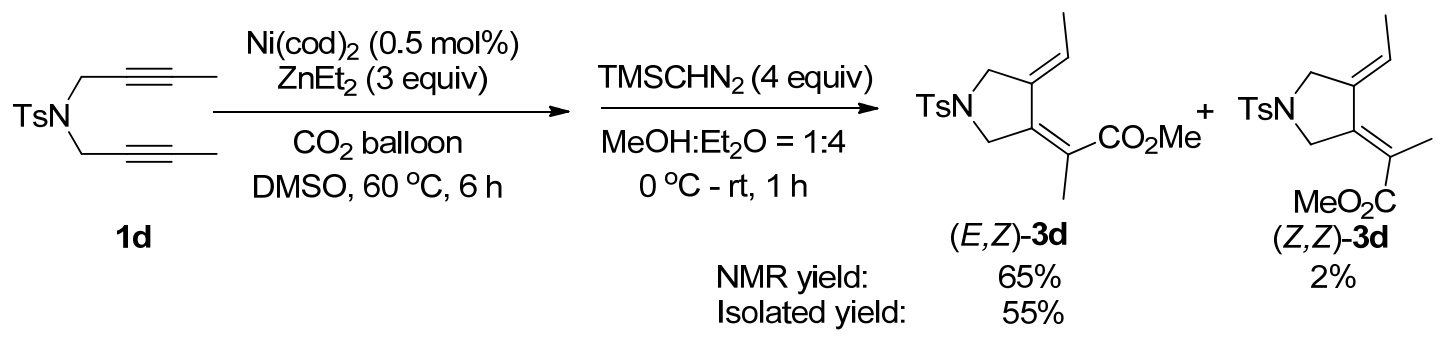

Following Typical Procedure: The reaction of $\mathrm{Ni}(\mathrm{cod})_{2}(1.3 \mathrm{mg}, 0.005 \mathrm{mmol})$, 1d $(276.2 \mathrm{mg}, 1.00 \mathrm{mmol}), \mathrm{ZnEt}_{2}(1.5 \mathrm{M}$ in toluene, $2.0 \mathrm{~mL}, 3.0 \mathrm{mmol})$, and carbon dioxide (about $1 \mathrm{~L}$ ) in $10 \mathrm{~mL}$ of DMSO for $6 \mathrm{~h}$ afforded the crude product. The crude product was then reacted with $\mathrm{TMSCHN}_{2}(2.0 \mathrm{M}$ in hexane, $2.0 \mathrm{~mL}, 4.0 \mathrm{mmol})$ in 1 $\mathrm{mL}$ of $\mathrm{MeOH}$ and $4 \mathrm{~mL}$ of $\mathrm{Et}_{2} \mathrm{O}$ afforded $(E, Z)-3 \mathbf{d}$ with the ratio of $(E, Z)-3 \mathbf{d} /(Z, Z)-\mathbf{3 d}$ determined by ${ }^{1} \mathrm{H}$ NMR analysis of the crude product to be 97:3. (E,Z)-3d (184.2 mg, $55 \%$ ) was obtained via column chromatography on silica gel (eluent: hexane/ethyl acetate/dichloromethane $=10 / 1 / 1)$ to afford an impure product and then recrystallization (hexane/dichloromethane $=5 / 1$ ) to afford a pure product as a white solid: m.p. 102-103 ${ }^{\circ} \mathrm{C}$ (hexane/dichloromethane); ${ }^{1} \mathrm{H}$ NMR $\left(400 \mathrm{MHz}, \mathrm{CDCl}_{3}\right) \delta 7.73$ (d, $J=8.0 \mathrm{~Hz}, 2 \mathrm{H}, \mathrm{ArH}), 7.34(\mathrm{~d}, J=8.0 \mathrm{~Hz}, 2 \mathrm{H}, \mathrm{ArH}), 5.90$ (q, $J=7.2 \mathrm{~Hz}, 1 \mathrm{H}$, $\mathrm{CH}=), 3.97\left(\mathrm{~s}, 2 \mathrm{H}, \mathrm{CH}_{2}\right), 3.96\left(\mathrm{~s}, 2 \mathrm{H}, \mathrm{CH}_{2}\right), 3.72\left(\mathrm{~s}, 3 \mathrm{H}, \mathrm{OCH}_{3}\right), 2.44\left(\mathrm{~s}, 3 \mathrm{H}, \mathrm{CH}_{3}\right)$, $1.84\left(\mathrm{~s}, 3 \mathrm{H}, \mathrm{CH}_{3}\right), 1.67\left(\mathrm{~d}, J=7.2 \mathrm{~Hz}, 3 \mathrm{H}, \mathrm{CH}_{3}\right) ;{ }^{13} \mathrm{C} \mathrm{NMR}\left(100 \mathrm{MHz}, \mathrm{CDCl}_{3}\right) \delta$ $170.1,143.9,135.8,132.5,131.7,129.7,127.7,123.6,120.5,52.2,51.9,51.0,21.5$, 18.0, 15.6; MS (EI) (m/z) $335\left(\mathrm{M}^{+}, 22.82\right), 148$ (100); IR (neat, $\left.\mathrm{cm}^{-1}\right)$ 1714, 1627, 1595, 1492, 1428, 1383, 1344, 1309, 1282, 1220, 1187, 1158, 1092, 1061, 1022; Anal. calcd for $\mathrm{C}_{17} \mathrm{H}_{21} \mathrm{NO}_{4} \mathrm{~S}$ (\%): C 60.87, H 6.31, N 4.18; found: C 60.99, H 6.49, N 3.91.

(6) Preparation of methyl (E)-2-((Z)-4-ethylidenedihydrofuran-3(2H)-ylidene) propanoate $[(E, Z)-3 \mathbf{e}](\mathrm{ct}-4-120)$ 


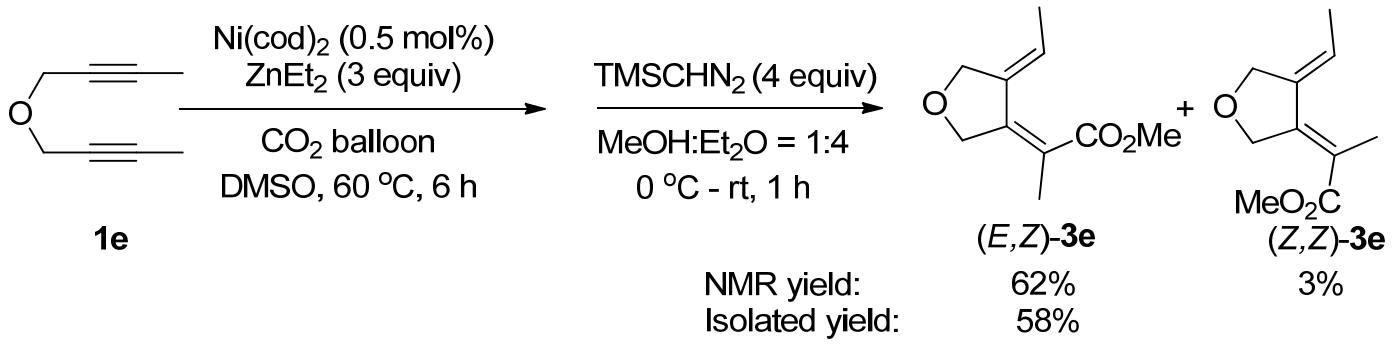

Following Typical Procedure: The reaction of $\mathrm{Ni}(\mathrm{cod})_{2}(1.4 \mathrm{mg}, 0.005 \mathrm{mmol})$, 1e $(122.2 \mathrm{mg}, 1.00 \mathrm{mmol}), \mathrm{ZnEt}_{2}(1.5 \mathrm{M}$ in toluene, $2.0 \mathrm{~mL}, 3.0 \mathrm{mmol})$, and carbon dioxide (about $1 \mathrm{~L}$ ) in $10 \mathrm{~mL}$ of DMSO for $6 \mathrm{~h}$ afforded the crude product. The crude product was then reacted with $\mathrm{TMSCHN}_{2}(2.0 \mathrm{M}$ in hexane, $2.0 \mathrm{~mL}, 4.0 \mathrm{mmol})$ in 1 $\mathrm{mL}$ of $\mathrm{MeOH}$ and $4 \mathrm{~mL}$ of $\mathrm{Et}_{2} \mathrm{O}$ afforded $(E, Z)$-3e with the ratio of $(E, Z)-3 \mathbf{e} /(Z, Z)-3 \mathbf{e}$ determined by ${ }^{1} \mathrm{H}$ NMR analysis of the crude product to be $95: 5$. Pure $(E, Z)-3 \mathbf{e}(105.2$ mg, 58\%) was obtained via column chromatography on silica gel (eluent: hexane/ethyl acetate $=30 / 1)$ as an oil: ${ }^{1} \mathrm{H}$ NMR $\left(400 \mathrm{MHz}, \mathrm{CDCl}_{3}\right) \delta 6.21(\mathrm{q}, J=7.2$ $\mathrm{Hz}, 1 \mathrm{H}, \mathrm{CH}=), 4.55\left(\mathrm{~s}, 2 \mathrm{H}, \mathrm{CH}_{2}\right), 4.52\left(\mathrm{~s}, 2 \mathrm{H}, \mathrm{CH}_{2}\right), 3.78\left(\mathrm{~s}, 3 \mathrm{H}, \mathrm{OCH}_{3}\right), 1.86(\mathrm{~s}, 3$ $\left.\mathrm{H}, \mathrm{CH}_{3}\right), 1.70\left(\mathrm{~d}, J=6.8 \mathrm{~Hz}, 3 \mathrm{H}, \mathrm{CH}_{3}\right) ;{ }^{13} \mathrm{C} \mathrm{NMR}\left(75 \mathrm{MHz}, \mathrm{CDCl}_{3}\right) \delta 169.8,140.2$, 134.5, 122.2, 117.8, 72.6, 71.6, 51.7, 17.6, 15.6; MS (EI) (m/z) $182\left(\mathrm{M}^{+}, 100\right)$; IR $\left(\right.$ neat, $\mathrm{cm}^{-1}$ ) 2950, 2836, 1717, 1662, 1434, 1343, 1274, 1192, 1156, 1098, 1056, 1018; HRMS calcd for $\mathrm{C}_{10} \mathrm{H}_{14} \mathrm{O}_{3}\left(\mathrm{M}^{+}\right)$: 182.0943; found: 182.0939 .

(7) Preparation of methyl (Z)-2-((E)-4,4-bis(((tert-butyldimethylsilyl)oxy)methyl)-2ethylidenecyclopentylidene)propanoate $[(Z, E)-3 \mathbf{f}]$ (ct-4-40)

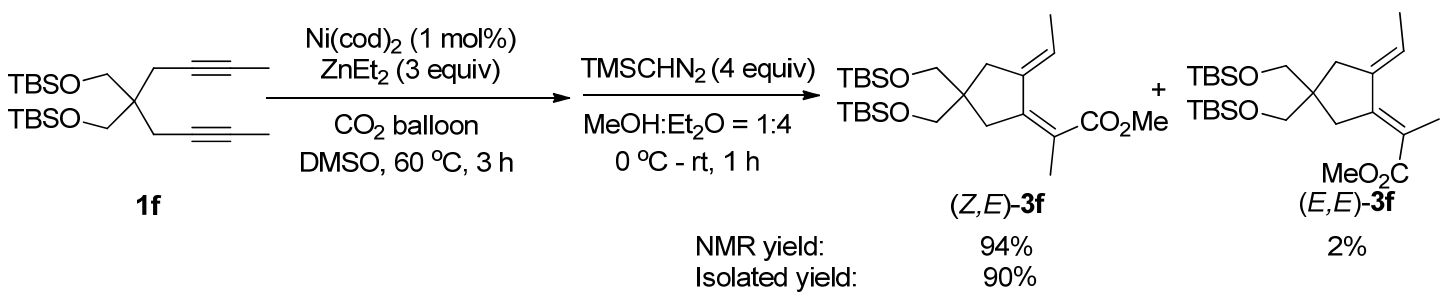

Following Typical Procedure: The reaction of Ni(cod $)_{2}(2.8 \mathrm{mg}, 0.01 \mathrm{mmol}), \mathbf{1 f}$ (408.5 mg, $1.00 \mathrm{mmol}), \mathrm{ZnEt}_{2}(1.5 \mathrm{M}$ in toluene, $2.0 \mathrm{~mL}, 3.0 \mathrm{mmol})$, and carbon dioxide (about $1 \mathrm{~L}$ ) in $10 \mathrm{~mL}$ of DMSO for $3 \mathrm{~h}$ afforded the crude product. The crude product was then reacted with $\mathrm{TMSCHN}_{2}(2.0 \mathrm{M}$ in hexane, $2.0 \mathrm{~mL}, 4.0 \mathrm{mmol})$ in 1 $\mathrm{mL}$ of $\mathrm{MeOH}$ and $4 \mathrm{~mL}$ of $\mathrm{Et}_{2} \mathrm{O}$ afforded $(Z, E)-3 \mathbf{f}$ with the ratio of $(Z, E)-\mathbf{3 f} /(E, E)-\mathbf{3 f}$ 
determined by ${ }^{1} \mathrm{H}$ NMR analysis of the crude product to be $98: 2$. Pure $(Z, E)$-3f (421.9 mg, 90\%) was obtained via column chromatography on silica gel (eluent: hexane to hexane/ethyl acetate $=100 / 1)$ as an oil: ${ }^{1} \mathrm{H}$ NMR $\left(400 \mathrm{MHz}, \mathrm{CDCl}_{3}\right) \delta 5.71(\mathrm{q}, J=6.8$ $\mathrm{Hz}, 1 \mathrm{H}, \mathrm{CH}=), 3.72\left(\mathrm{~s}, 3 \mathrm{H}, \mathrm{OCH}_{3}\right), 3.42\left(\mathrm{AB}, J_{A B}=9.6 \mathrm{~Hz}, 2 \mathrm{H}\right.$, (one proton of $\mathrm{CH}_{2}$ ) $\times 2), 3.39\left(\mathrm{AB}, J_{A B}=9.6 \mathrm{~Hz}, 2 \mathrm{H}\right.$, (one proton of $\left.\left.\mathrm{CH}_{2}\right) \times 2\right), 2.21\left(\mathrm{~s}, 2 \mathrm{H}, \mathrm{CH}_{2}\right), 2.19$ (s, $\left.2 \mathrm{H}, \mathrm{CH}_{2}\right), 1.87\left(\mathrm{~s}, 3 \mathrm{H}, \mathrm{CH}_{3}\right), 1.67\left(\mathrm{~d}, J=7.2 \mathrm{~Hz}, 3 \mathrm{H}, \mathrm{CH}_{3}\right), 0.88(\mathrm{~s}, 18 \mathrm{H}$, $\left.\mathrm{C}\left(\mathrm{CH}_{3}\right)_{3} \times 2\right), 0.02\left(\mathrm{~s}, 12 \mathrm{H}, \mathrm{CH}_{3} \times 4\right) ;{ }^{13} \mathrm{C} \mathrm{NMR}\left(100 \mathrm{MHz}, \mathrm{CDCl}_{3}\right) \delta 172.2,143.1$, 138.2, 121.4, 119.1, 65.0, 51.6, 46.0, 37.0, 34.8, 25.9, 18.3, 18.1, 15.5, -5.5, -5.6; MS (EI) (m/z) $468\left(\mathrm{M}^{+}, 1.55\right), 105$ (100); IR (neat, $\left.\mathrm{cm}^{-1}\right)$ 2953, 2930, 2898, 2856, 1723, 1468, 1433, 1388, 1361, 1291, 1253, 1214, 1148, 1094, 1006; HRMS calcd for $\mathrm{C}_{25} \mathrm{H}_{48} \mathrm{O}_{4} \mathrm{Si}_{2}\left(\mathrm{M}^{+}\right)$: 468.3091 ; found: 468.3096 .

(8) Preparation of methyl (Z)-2-((E)-4,4-bis((benzyloxy)methyl)-2ethylidenecyclopentylidene)propanoate $[(Z, E)-3 g]($ ct-4-134)

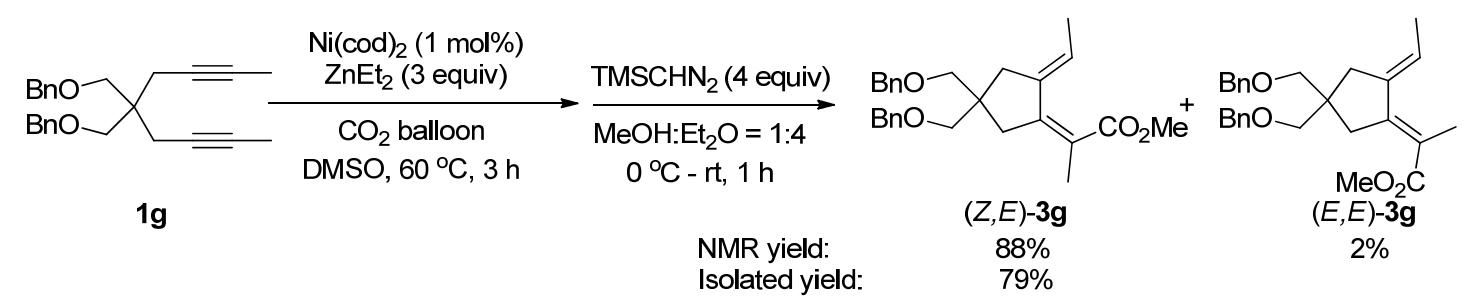

Following Typical Procedure: The reaction of $\mathrm{Ni}(\operatorname{cod})_{2}(2.8 \mathrm{mg}, 0.01 \mathrm{mmol})$, $1 \mathrm{~g}(359.9 \mathrm{mg}, 1.00 \mathrm{mmol}), \mathrm{ZnEt}_{2}(1.5 \mathrm{M}$ in toluene, $2.0 \mathrm{~mL}, 3.0 \mathrm{mmol})$, and carbon dioxide (about $1 \mathrm{~L}$ ) in $10 \mathrm{~mL}$ of DMSO for $3 \mathrm{~h}$ afforded the crude product. The crude product was then reacted with $\mathrm{TMSCHN}_{2}(2.0 \mathrm{M}$ in hexane, $2.0 \mathrm{~mL}, 4.0 \mathrm{mmol})$ in 1 $\mathrm{mL}$ of $\mathrm{MeOH}$ and $4 \mathrm{~mL}$ of $\mathrm{Et}_{2} \mathrm{O}$ afforded $(Z, E)-3 \mathbf{g}$ with the ratio of $(Z, E)-3 \mathbf{g} /(E, E)-\mathbf{3 g}$ determined by ${ }^{1} \mathrm{H}$ NMR analysis of the crude product to be 98:2. Pure $(Z, E)$-3g (330.5 mg, 79\%) was obtained via column chromatography on neutral aluminum oxide (eluent: hexane/ethyl acetate $=30 / 1$ for the first round; the impure part was submitted to the second round under the same eluent) as an oil: ${ }^{1} \mathrm{H} \mathrm{NMR}\left(400 \mathrm{MHz}, \mathrm{CDCl}_{3}\right) \delta$ 7.36-7.23 (m, $10 \mathrm{H}, \mathrm{ArH}), 5.72(\mathrm{q}, J=6.9 \mathrm{~Hz}, 1 \mathrm{H}, \mathrm{CH}=), 4.52\left(\mathrm{AB}, J_{A B}=12.8 \mathrm{~Hz}, 2\right.$ $\mathrm{H}$, (one proton of $\left.\left.\mathrm{CH}_{2}\right) \times 2\right), 4.49\left(\mathrm{AB}, J_{A B}=12.4 \mathrm{~Hz}, 2 \mathrm{H}\right.$, (one proton of $\left.\mathrm{CH}_{2}\right) \times 2$ ), $3.71\left(\mathrm{~s}, 3 \mathrm{H}, \mathrm{OCH}_{3}\right), 3.40\left(\mathrm{AB}, J_{A B}=9.2 \mathrm{~Hz}, 2 \mathrm{H}\right.$, (one proton of $\left.\left.\mathrm{CH}_{2}\right) \times 2\right), 3.37(\mathrm{AB}$, 
$J_{A B}=9.2 \mathrm{~Hz}, 2 \mathrm{H}$, (one proton of $\left.\left.\mathrm{CH}_{2}\right) \times 2\right), 2.35\left(\mathrm{~s}, 2 \mathrm{H}, \mathrm{CH}_{2}\right), 2.33\left(\mathrm{~s}, 2 \mathrm{H}, \mathrm{CH}_{2}\right)$, $1.85\left(\mathrm{~s}, 3 \mathrm{H}, \mathrm{CH}_{3}\right), 1.66\left(\mathrm{~d}, J=6.8 \mathrm{~Hz}, 3 \mathrm{H}, \mathrm{CH}_{3}\right) ;{ }^{13} \mathrm{C} \mathrm{NMR}\left(100 \mathrm{MHz}, \mathrm{CDCl}_{3}\right) \delta$ $172.1,142.4,138.6,137.8,128.2,127.4,121.8,119.4,73.2,73.0,51.7,44.1,38.0$, 36.0, 18.2, 15.6; MS (EI) (m/z) $420\left(\mathrm{M}^{+}, 1.71\right), 91$ (100); IR (neat, $\mathrm{cm}^{-1}$ ) 3030, 2892, 2853, 1718, 1496, 1453, 1431, 1362, 1290, 1208, 1148, 1093, 1027; HRMS calcd for $\mathrm{C}_{27} \mathrm{H}_{32} \mathrm{O}_{4}\left(\mathrm{M}^{+}\right): 420.2301$; found: 420.2300 .

(9) Preparation of methyl (Z)-2-((E)-2-ethylidene-4,4,5,5-tetrakis(ethoxycarbonyl) cyclohexylidene)propanoate $[(Z, E)-3 h]($ ct-4-65)
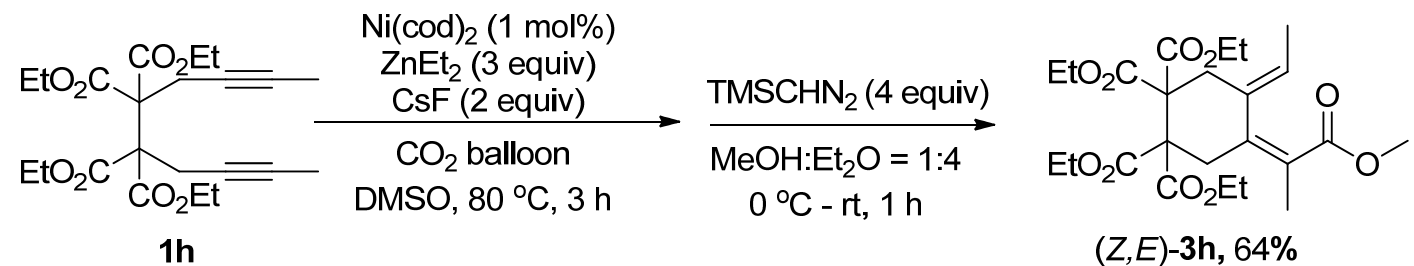

To a $50 \mathrm{~mL}$ flame-dried Schlenk tube was added $\mathrm{Ni}(\operatorname{cod})_{2}(2.8 \mathrm{mg}, 0.01 \mathrm{mmol})$ and CsF (303.4 mg, $2.00 \mathrm{mmol})$ inside a glove box. Compound $\mathbf{1 h}(422.2 \mathrm{mg}, 1.00$ mmol) and DMSO (10 mL) were sequentially added under argon outside the glove box. The Schlenk tube was then frozen with a liquid nitrogen bath. The argon inside the tube was completely replaced with $\mathrm{CO}_{2}$ by using a balloon of $\mathrm{CO}_{2}$ (about $1 \mathrm{~L}$ ). The Schlenk tube was allowed to stand until the temperature was above $0{ }^{\circ} \mathrm{C}$. Then the Schlenk tube was placed in an oil bath pre-heated at $80{ }^{\circ} \mathrm{C}$. After completely thawed, to the mixture was added $\mathrm{ZnEt}_{2}(1.5 \mathrm{M}$ in toluene, $2.0 \mathrm{~mL}, 3.0 \mathrm{mmol})$ with a syringe. After being vigorously stirred for $3 \mathrm{~h}$, the reaction was complete as monitored by TLC. $3 \mathrm{M} \mathrm{HCl}(5 \mathrm{~mL})$ was added to quench the reaction. The aqueous layer was extracted with EtOAc $(5 \mathrm{~mL} \times 3)$ and the combined organic layer was washed with brine $(10 \mathrm{~mL})$, dried over anhydrous $\mathrm{MgSO}_{4}$, filtered and concentrated in vacuo. To the crude product were added $\mathrm{MeOH}(1 \mathrm{~mL})$ and $\mathrm{Et}_{2} \mathrm{O}(4 \mathrm{~mL})$ and the flask containing the mixture was placed in an ice bath. To the resulting mixture was dropwise added $\mathrm{TMSCHN}_{2}(2.0 \mathrm{M}$ in hexane, $2.0 \mathrm{~mL}, 4.0 \mathrm{mmol})$ with a syringe. After being stirred for $1 \mathrm{~h}$ at room temperature, the reaction was complete as monitored by TLC. The reaction mixture was concentrated and the ratio of 
$(Z, E)-3 \mathbf{h} /(E, E)-3 \mathbf{h}$ was determined by ${ }^{1} \mathrm{H}$ NMR analysis of the crude product to be 100:0. Pure $(Z, E)$-3h (307.2 mg, 64\%) was obtained via column chromatography on silica gel (eluent: petroleum ether $\left(30-60{ }^{\circ} \mathrm{C}\right) /$ ethyl acetate $\left.=5 / 1\right)$ as an oil: ${ }^{1} \mathrm{H}$ NMR $\left(400 \mathrm{MHz}, \mathrm{CDCl}_{3}\right) \delta 5.44(\mathrm{q}, J=6.9 \mathrm{~Hz}, 1 \mathrm{H}, \mathrm{CH}=), 4.27-4.13\left(\mathrm{~m}, 8 \mathrm{H}, \mathrm{OCH}_{2} \times 4\right)$, $3.60\left(\mathrm{~s}, 3 \mathrm{H}, \mathrm{OCH}_{3}\right), 3.09\left(\mathrm{~s}, 2 \mathrm{H}, \mathrm{CH}_{2}\right), 3.00\left(\mathrm{~s}, 2 \mathrm{H}, \mathrm{CH}_{2}\right), 1.87\left(\mathrm{~s}, 3 \mathrm{H},=\mathrm{C}(\mathrm{CO}) \mathrm{CH}_{3}\right)$, $1.61\left(\mathrm{~d}, J=6.8 \mathrm{~Hz}, 3 \mathrm{H}, \mathrm{CH}_{3}\right), 1.31-1.23\left(\mathrm{~m}, 12 \mathrm{H}, \mathrm{CH}_{3} \times 4\right) ;{ }^{13} \mathrm{C} \mathrm{NMR}(100 \mathrm{MHz}$, $\left.\mathrm{CDCl}_{3}\right) \delta 172.3,169.4,140.2,134.4,124.6,123.8,61.74,61.72,59.7,59.6,51.4,33.4$, 31.7, 15.7, 13.8, 13.7, 13.4; MS (EI) (m/z) $482\left(\mathrm{M}^{+}, 8.20\right), 289$ (100); IR (neat, $\mathrm{cm}^{-1}$ ) 2983, 1721, 1442, 1389, 1367, 1256, 1229, 1192, 1153, 1093, 1039; HRMS calcd for $\mathrm{C}_{24} \mathrm{H}_{34} \mathrm{O}_{10}\left(\mathrm{M}^{+}\right)$: 482.2152; found: 482.2149.

\section{Gram scale synthesis (ct-5-43)}

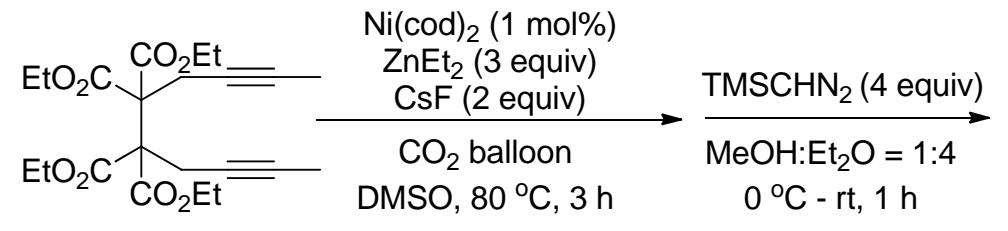

1h

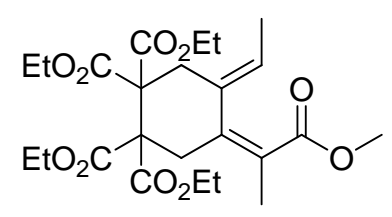

$(Z, E)-3 h, 73 \%$ purity of $96 \%$

To a $250 \mathrm{~mL}$ flame-dried Schlenk tube was added $\mathrm{Ni}(\operatorname{cod})_{2}(10.8 \mathrm{mg}, 0.04 \mathrm{mmol})$ and CsF (1.2090 g, 7.96 mmol) inside a glove box. Compound $\mathbf{1 h}$ (1.6894 g, 4.00 mmol) and DMSO (40 mL) were sequentially added under argon outside the glove box. The Schlenk tube was then frozen with a liquid nitrogen bath. The argon inside the tube was completely replaced with $\mathrm{CO}_{2}$ by using a balloon of $\mathrm{CO}_{2}$ (about $1 \mathrm{~L}$ ). The Schlenk tube was allowed to stand until the temperature was above $0{ }^{\circ} \mathrm{C}$. Then the Schlenk tube was placed in an oil bath pre-heated at $80{ }^{\circ} \mathrm{C}$. After completely thawed, to the mixture was added $\mathrm{ZnEt}_{2}(1.5 \mathrm{M}$ in toluene, $8.0 \mathrm{~mL}, 12.0 \mathrm{mmol})$ with a syringe. After being vigorously stirred for $3 \mathrm{~h}$, the reaction was complete as monitored by TLC. $3 \mathrm{M} \mathrm{HCl}(30 \mathrm{~mL})$ was added to quench the reaction. The aqueous layer was extracted with EtOAc $(20 \mathrm{~mL} \times 5)$ and the combined organic layer was washed with brine $(50 \mathrm{~mL})$, dried over anhydrous $\mathrm{MgSO}_{4}$, filtered and concentrated in vacuo. To the crude product were added $\mathrm{MeOH}(5 \mathrm{~mL})$ and $\mathrm{Et}_{2} \mathrm{O}(20 \mathrm{~mL})$ and the flask containing the mixture was placed in an ice bath. To the resulting mixture was 
dropwise added $\mathrm{TMSCHN}_{2}(2.0 \mathrm{M}$ in hexane, $8.0 \mathrm{~mL}, 16.0 \mathrm{mmol})$ with a syringe. After being stirred for $1 \mathrm{~h}$ at room temperature, the reaction was complete as monitored by TLC. The reaction mixture was concentrated and the ratio of $(Z, E)-3 \mathbf{h} /(E, E)$-3h was determined by ${ }^{1} \mathrm{H}$ NMR analysis of the crude product to be 100:0. (Z,E)-3h (1.4702 g, purity of $96 \%, 73 \%)$ was obtained via column chromatography on silica gel (eluent: petroleum ether/ethyl acetate $=5 / 1$ ) as an oil: ${ }^{1} \mathrm{H}$ NMR (400 MHz, $\left.\mathrm{CDCl}_{3}\right) \delta 5.44(\mathrm{q}, J=6.8 \mathrm{~Hz}, 1 \mathrm{H}, \mathrm{CH}=), 4.28-4.15\left(\mathrm{~m}, 8 \mathrm{H}, \mathrm{OCH}_{2}\right.$ × 4), $3.60\left(\mathrm{~s}, 3 \mathrm{H}, \mathrm{OCH}_{3}\right), 3.09$ (bs, $\left.2 \mathrm{H}, \mathrm{CH}_{2}\right), 3.00\left(\mathrm{bs}, 2 \mathrm{H}, \mathrm{CH}_{2}\right), 1.87\left(\mathrm{~s}, 3 \mathrm{H}, \mathrm{CH}_{3}\right)$, $1.62\left(\mathrm{~d}, J=7.2 \mathrm{~Hz}, 3 \mathrm{H}, \mathrm{CH}_{3}\right), 1.31-1.24\left(\mathrm{~m}, 12 \mathrm{H}, \mathrm{CH}_{3} \times 4\right) ;{ }^{13} \mathrm{C}$ NMR $(100 \mathrm{MHz}$, $\left.\mathrm{CDCl}_{3}\right) \delta 172.2,169.3,140.1,134.3,124.5,123.7,61.64,61.61,59.6,59.5,51.3,33.3$, 31.6, 15.6, 13.7, 13.6, 13.3.

(10) Preparation of methyl (Z)-2-((E)-2-propylidene-4,4,5,5-tetrakis(ethoxycarbonyl) cyclohexylidene)butanoate $[(Z, E)-3 \mathbf{i}]($ ct-7-172)

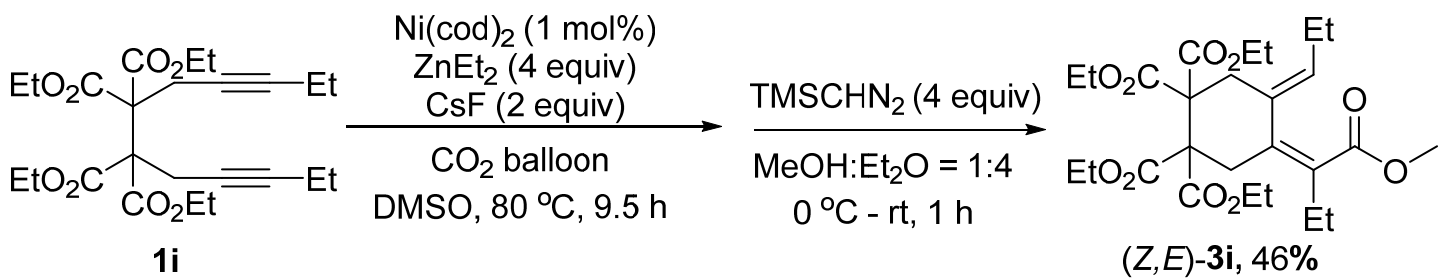

To a $25 \mathrm{~mL}$ flame-dried Schlenk tube was added compound 1i (purity of $80 \%$, $282.0 \mathrm{mg}, 0.5 \mathrm{mmol})$, DMSO $(5 \mathrm{~mL})$ and $\mathrm{ZnEt}_{2}(1.5 \mathrm{M}$ in toluene, $1.33 \mathrm{~mL}, 2.0 \mathrm{mmol})$ under argon. Then the Schlenk tube was moved to a glovebox, and $\mathrm{Ni}(\operatorname{cod})_{2}(1.4 \mathrm{mg}$, $0.005 \mathrm{mmol})$ and $\mathrm{CsF}(152.1 \mathrm{mg}, 1.0 \mathrm{mmol})$ were added. After being moved out of the glovebox, the Schlenk tube was frozen with a liquid nitrogen bath. The argon inside the tube was completely replaced with $\mathrm{CO}_{2}$ by using a balloon of $\mathrm{CO}_{2}$ (about 1 L). The Schlenk tube was allowed to stand until the temperature was above $0{ }^{\circ} \mathrm{C}$. Then the Schlenk tube was placed in an oil bath pre-heated at $80{ }^{\circ} \mathrm{C}$. After being vigorously stirred for $9.5 \mathrm{~h}$, the reaction was complete as monitored by TLC. $3 \mathrm{M} \mathrm{HCl}$ $(5 \mathrm{~mL})$ was added to quench the reaction. The aqueous layer was extracted with EtOAc $(5 \mathrm{~mL} \times 3)$ and the combined organic layer was washed with brine $(10 \mathrm{~mL})$, dried over anhydrous $\mathrm{MgSO}_{4}$, filtered and concentrated in vacuo. To the crude 
product were added $\mathrm{MeOH}(1 \mathrm{~mL})$ and $\mathrm{Et}_{2} \mathrm{O}(4 \mathrm{~mL})$ and the flask containing the mixture was placed in an ice bath. To the resulting mixture was dropwise added $\mathrm{TMSCHN}_{2}(2.0 \mathrm{M}$ in hexane, $1.0 \mathrm{~mL}, 2.0 \mathrm{mmol})$ with a syringe. After being stirred for $1 \mathrm{~h}$ at room temperature, the reaction was complete as monitored by TLC. The reaction mixture was concentrated and the ratio of $(Z, E)-3 \mathbf{i} /(E, E)-3 \mathbf{i}$ was determined by ${ }^{1} \mathrm{H}$ NMR analysis of the crude product to be $100: 0 .(Z, E)-3 \mathbf{i}(117.6 \mathrm{mg}, 46 \%)$ was obtained via column chromatography on silica gel (eluent: petroleum ether/ethyl acetate $=7 / 1)$ as an oil: ${ }^{1} \mathrm{H}$ NMR $\left(400 \mathrm{MHz}, \mathrm{CDCl}_{3}\right) \delta 5.38(\mathrm{t}, J=7.2 \mathrm{~Hz}, 1 \mathrm{H}, \mathrm{CH}=)$, 4.28-4.11 (m, $\left.8 \mathrm{H}, \mathrm{CH}_{2} \times 4\right), 3.61\left(\mathrm{~s}, 3 \mathrm{H}, \mathrm{OCH}_{3}\right), 3.12\left(\mathrm{~s}, 2 \mathrm{H}, \mathrm{CH}_{2}\right), 2.97$ (bs, $2 \mathrm{H}$, $\mathrm{CH}_{2}$ ), 2.29 (q, $J=7.2 \mathrm{~Hz}, 2 \mathrm{H}, \mathrm{CH}_{2}$ ), 2.09-1.99 (m, $2 \mathrm{H}, \mathrm{CH}_{2}$ ), 1.27 (t, $J=7.2 \mathrm{~Hz}, 12$ $\left.\mathrm{H}, \mathrm{CH}_{3} \times 4\right), 0.99\left(\mathrm{t}, J=7.4 \mathrm{~Hz}, 3 \mathrm{H}, \mathrm{CH}_{3}\right), 0.92\left(\mathrm{t}, J=7.4 \mathrm{~Hz}, 3 \mathrm{H}, \mathrm{CH}_{3}\right) ;{ }^{13} \mathrm{C} \mathrm{NMR}$ $\left(100 \mathrm{MHz}, \mathrm{CDCl}_{3}\right) \delta 172.0,169.4,138.9,133.1,131.5,131.2,61.74,61.70,59.9$, 59.5, 51.2, 33.0, 31.9, 23.1, 21.0, 13.9, 13.74, 13.69, 13.0; MS (EI) (m/z) $510\left(\mathrm{M}^{+}\right.$, 27.36), 481 (100); IR (neat, $\mathrm{cm}^{-1}$ ) 2977, 2879, 1728, 1643, 1447, 1374, 1238, 1195 , 1105, 1040; HRMS calcd for $\mathrm{C}_{26} \mathrm{H}_{38} \mathrm{O}_{10}\left(\mathrm{M}^{+}\right)$: 510.2465; found: 510.2459.

(11) Preparation of methyl (Z)-2-((E)-2-hydroxypropylidene-4,4-bis(methoxy carbonyl)cyclopentylidene)propanoate $[(Z, E)-3 \mathbf{j}]$ (ct-4-68)

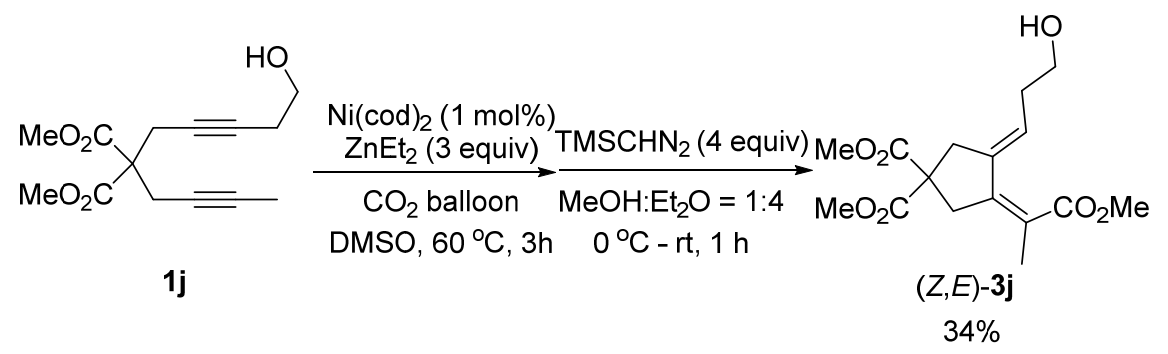

Following Typical Procedure: The reaction of $\mathrm{Ni}(\operatorname{cod})_{2}(2.8 \mathrm{mg}, 0.01 \mathrm{mmol}), \mathbf{1 j}$ (266.2 $\mathrm{mg}, 1.00 \mathrm{mmol}), \mathrm{ZnEt}_{2}(1.5 \mathrm{M}$ in toluene, $2.0 \mathrm{~mL}, 3.0 \mathrm{mmol})$, and carbon dioxide (about $1 \mathrm{~L}$ ) in $10 \mathrm{~mL}$ of DMSO for $3 \mathrm{~h}$ afforded the crude product. The crude product was then reacted with $\mathrm{TMSCHN}_{2}(2.0 \mathrm{M}$ in hexane, $2.0 \mathrm{~mL}, 4.0 \mathrm{mmol})$ in 1 $\mathrm{mL}$ of $\mathrm{MeOH}$ and $4 \mathrm{~mL}$ of $\mathrm{Et}_{2} \mathrm{O}$ afforded $(Z, E)-3 \mathbf{j}$ (109.9 mg, 34\%) via column chromatography on silica gel (eluent: petroleum ether/ethyl acetate $=4 / 1$ to $1 / 1$ ) as an oil: ${ }^{1} \mathrm{H}$ NMR $\left(400 \mathrm{MHz}, \mathrm{CDCl}_{3}\right) \delta 5.70(\mathrm{t}, J=7.6 \mathrm{~Hz}, 1 \mathrm{H}, \mathrm{CH}=), 3.74\left(\mathrm{~s}, 6 \mathrm{H}, \mathrm{OCH}_{3}\right.$ 
× 2), $3.72\left(\mathrm{~s}, 3 \mathrm{H}, \mathrm{OCH}_{3}\right), 3.66\left(\mathrm{t}, J=5.8 \mathrm{~Hz}, 2 \mathrm{H}, \mathrm{OCH}_{2}\right), 3.04\left(\mathrm{~s}, 2 \mathrm{H}, \mathrm{CH}_{2}\right), 3.02(\mathrm{~s}$, $\left.2 \mathrm{H}, \mathrm{CH}_{2}\right), 2.38\left(\mathrm{q}, J=6.7 \mathrm{~Hz}, 2 \mathrm{H}, \mathrm{CH}_{2}\right), 2.06(\mathrm{~s}, 1 \mathrm{H}, \mathrm{OH}), 1.91\left(\mathrm{~s}, 3 \mathrm{H}, \mathrm{CH}_{3}\right) ;{ }^{13} \mathrm{C}$ NMR $\left(100 \mathrm{MHz}, \mathrm{CDCl}_{3}\right) \delta 171.6,171.1,140.1,137.5,124.5,121.2,61.7,56.4,53.0$, 51.8, 38.8, 37.8, 33.5, 18.0; MS (EI) (m/z) $326\left(\mathrm{M}^{+}, 21.40\right), 281$ (100); IR (neat, $\mathrm{cm}^{-1}$ ) 2954, 1728, 1434, 1253, 1202, 1166, 1141, 1102, 1053; HRMS calcd for $\mathrm{C}_{16} \mathrm{H}_{22} \mathrm{O}_{7}$ $\left(\mathrm{M}^{+}\right)$: 326.1366; found: 326.1371 .

(12) Preparation of methyl (Z)-2-((E)-2-(4-fluorophenylmethylene)-4,4-bis(methoxy carbonyl)cyclopentylidene)propanoate $[(Z, E)-3 \mathbf{k}]$ (ct-5-147)

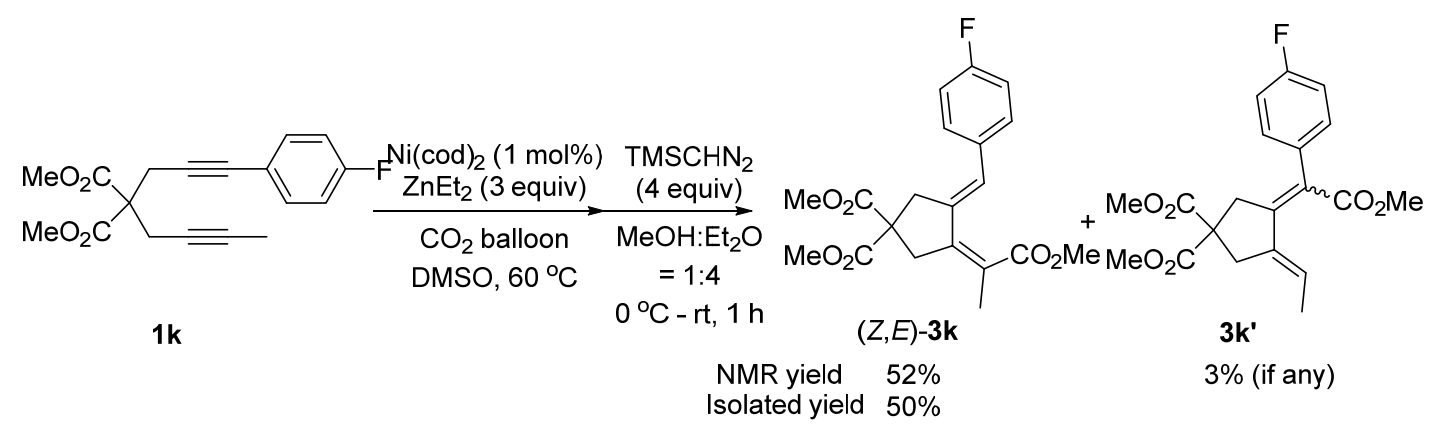

Following Typical Procedure: The reaction of $\mathrm{Ni}(\operatorname{cod})_{2}(2.8 \mathrm{mg}, 0.01 \mathrm{mmol})$, $1 \mathbf{k}(316.0 \mathrm{mg}, 1.00 \mathrm{mmol}), \mathrm{ZnEt}_{2}(1.5 \mathrm{M}$ in toluene, $2.0 \mathrm{~mL}, 3.0 \mathrm{mmol})$, and carbon dioxide (about $1 \mathrm{~L}$ ) in $10 \mathrm{~mL}$ of DMSO for $3 \mathrm{~h}$ afforded the crude product. The crude product was then reacted with $\mathrm{TMSCHN}_{2}(2.0 \mathrm{M}$ in hexane, $2.0 \mathrm{~mL}, 4.0 \mathrm{mmol})$ in 1 $\mathrm{mL}$ of $\mathrm{MeOH}$ and $4 \mathrm{~mL}$ of $\mathrm{Et}_{2} \mathrm{O}$ afforded $(Z, E)-3 \mathbf{k}$ and 3k', the yields of which were determined by ${ }^{1} \mathrm{H}$ NMR analysis of the crude products using $\mathrm{CH}_{2} \mathrm{Br}_{2}$ as the internal standard (52\% and $3 \%$, respectively). $17 \%$ of the protonolysis product was also observed in the crude product. Pure $(Z, E)-3 \mathbf{k}(189.6 \mathrm{mg}, 50 \%)$ was obtained via column chromatography on silica gel (eluent: hexane/ethyl acetate $=10 / 1$ for the first round; the impure part was submitted to the second round under the eluent of hexane/ethyl acetate $=15 / 1$ ) as a white solid: m.p. 97-98 ${ }^{\circ} \mathrm{C}$ (petroleum ether/ethyl acetate); ${ }^{1} \mathrm{H}$ NMR (400 MHz, $\left.\mathrm{CDCl}_{3}\right) \delta$ 7.28-7.21 (m, $\left.2 \mathrm{H}, \mathrm{ArH}\right), 7.06-6.99$ (m, $2 \mathrm{H}$, $\mathrm{ArH}), 6.65(\mathrm{~s}, 1 \mathrm{H}, \mathrm{CH}=), 3.704\left(\mathrm{~s}, 6 \mathrm{H}, \mathrm{OCH}_{3} \times 2\right), 3.698\left(\mathrm{~s}, 3 \mathrm{H}, \mathrm{OCH}_{3}\right), 3.27(\mathrm{~d}, J=$ $\left.2.0 \mathrm{~Hz}, 2 \mathrm{H}, \mathrm{CH}_{2}\right), 3.07$ (d, $\left.J=1.2 \mathrm{~Hz}, 2 \mathrm{H}, \mathrm{CH}_{2}\right), 1.99\left(\mathrm{~s}, 3 \mathrm{H}, \mathrm{CH}_{3}\right) ;{ }^{13} \mathrm{C} \mathrm{NMR}(100$ $\left.\mathrm{MHz}, \mathrm{CDCl}_{3}\right) \delta 171.4,171.2,161.9(\mathrm{~d}, J=246.7 \mathrm{~Hz}), 141.2,135.9(\mathrm{~d}, J=1.6 \mathrm{~Hz})$, 
$133.2(\mathrm{~d}, J=3.0 \mathrm{~Hz}), 130.7(\mathrm{~d}, J=7.9 \mathrm{~Hz}), 126.2,122.0,115.2(\mathrm{~d}, J=21.6 \mathrm{~Hz}), 57.1$, 53.0, 51.9, 39.2, 38.0, 18.3; ${ }^{19} \mathrm{~F}$ NMR (376 MHz, $\left.\mathrm{CDCl}_{3}\right) \delta-114.4$; MS (EI) (m/z) 376 $\left(\mathrm{M}^{+}, 3.84\right), 194$ (100); IR (neat, $\mathrm{cm}^{-1}$ ) 2955, 1729, 1714, 1647, 1597, 1506, 1434, $1373,1262,1221,1201,1158,1139,1069,1049$, 1010; Anal. calcd for $\mathrm{C}_{20} \mathrm{H}_{21} \mathrm{FO}_{6}$ (\%): C 63.82, H 5.62; found: C 63.98, H 5.70.

(13) Preparation of methyl (Z)-2-((E)-2-(4-methoxycarbonylphenylmethylene)-4,4bis(methoxycarbonyl)cyclopentylidene)propanoate $[(Z, E)-3 \mathbf{l}]$ (ct-5-163)

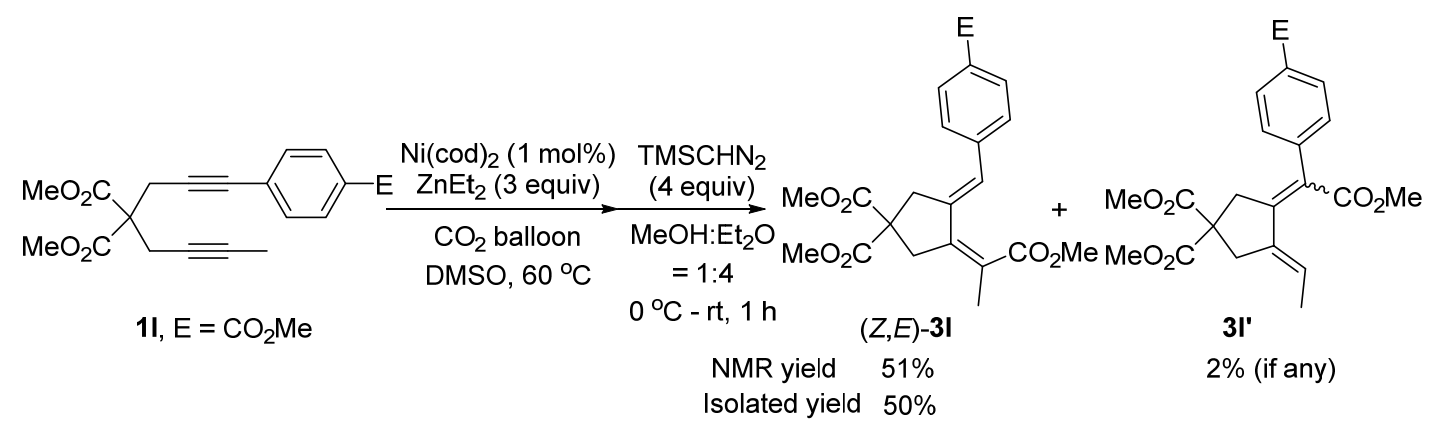

Following Typical Procedure: The reaction of $\mathrm{Ni}(\operatorname{cod})_{2}(2.9 \mathrm{mg}, 0.01 \mathrm{mmol}), \mathbf{1 l}$ (357.3 mg, $1.00 \mathrm{mmol}$ ), $\mathrm{ZnEt}_{2}(1.5 \mathrm{M}$ in toluene, $2.0 \mathrm{~mL}, 3.0 \mathrm{mmol}$ ), and carbon dioxide (about $1 \mathrm{~L}$ ) in $10 \mathrm{~mL}$ of DMSO for $3 \mathrm{~h}$ afforded the crude product. The crude product was then reacted with $\mathrm{TMSCHN}_{2}(2.0 \mathrm{M}$ in hexane, $2.0 \mathrm{~mL}, 4.0 \mathrm{mmol})$ in 1 $\mathrm{mL}$ of $\mathrm{MeOH}$ and $4 \mathrm{~mL}$ of $\mathrm{Et}_{2} \mathrm{O}$ afforded $(Z, E)-3 \mathbf{l}$ and 3l', the yields of which were determined by ${ }^{1} \mathrm{H}$ NMR analysis of the crude products using $\mathrm{CH}_{2} \mathrm{Br}_{2}$ as the internal standard (51\% and $2 \%$, respectively). $15 \%$ of the protonolysis product was also observed in the crude product. Pure $(Z, E)-31$ (207.3 mg, 50\%) was obtained via column chromatography on silica gel (eluent: hexane/ethyl acetate $=10 / 1$ ) as a white solid: m.p. $126-127{ }^{\circ} \mathrm{C}$ (petroleum ether/ethyl acetate); ${ }^{1} \mathrm{H}$ NMR (400 MHz, $\left.\mathrm{CDCl}_{3}\right) \delta$ $8.00(\mathrm{~d}, J=8.0 \mathrm{~Hz}, 2 \mathrm{H}, \mathrm{ArH}), 7.34$ (d, $J=8.4 \mathrm{~Hz}, 2 \mathrm{H}, \mathrm{ArH}), 6.72$ (s, $1 \mathrm{H}, \mathrm{CH}=)$, $3.92\left(\mathrm{~s}, 3 \mathrm{H}, \mathrm{OCH}_{3}\right), 3.71\left(\mathrm{~s}, 3 \mathrm{H}, \mathrm{OCH}_{3}\right), 3.70\left(\mathrm{~s}, 6 \mathrm{H}, \mathrm{OCH}_{3} \times 2\right), 3.32(\mathrm{~d}, J=2.0 \mathrm{~Hz}$, $\left.2 \mathrm{H}, \mathrm{CH}_{2}\right), 3.08\left(\mathrm{~s}, 2 \mathrm{H}, \mathrm{CH}_{2}\right), 2.00\left(\mathrm{~s}, 3 \mathrm{H}, \mathrm{CH}_{3}\right) ;{ }^{13} \mathrm{C} \mathrm{NMR}\left(100 \mathrm{MHz}, \mathrm{CDCl}_{3}\right) \delta$ 171.2, 170.9, 166.7, 141.5, 140.8, 138.5, 129.5, 128.9, 128.5, 126.2, 123.1, 57.0, 53.0, 52.0, 51.9, 39.4, 37.9, 18.4; MS (EI) (m/z) $416\left(\mathrm{M}^{+}, 34.01\right), 297$ (100); IR (neat, $\mathrm{cm}^{-1}$ ) $1743,1727,1704,1637,1600,1560,1433,1353,1300,1257,1197,1136,1115,1071$, 
1053, 1015; Anal. calcd for $\mathrm{C}_{22} \mathrm{H}_{24} \mathrm{O}_{8}$ (\%): C 63.45, H 5.81; found: C 63.28, H 5.89.

(14) Preparation of methyl (Z)-2-((E)-2-(3-methoxyphenylmethylene)-4,4bis(methoxycarbonyl)cyclopentylidene)propanoate $[(Z, E)-3 \mathbf{m}](\mathrm{ct}-6-20)$

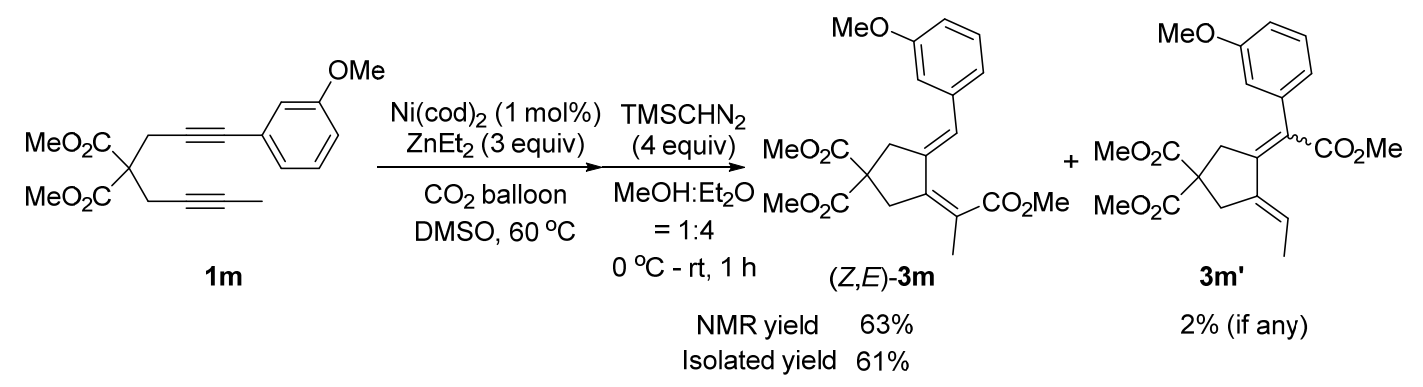

Following Typical Procedure: The reaction of $\mathrm{Ni}(\operatorname{cod})_{2}(2.8 \mathrm{mg}, 0.01 \mathrm{mmol})$, $1 \mathrm{~m}(328.9 \mathrm{mg}, 1.00 \mathrm{mmol}), \mathrm{ZnEt}_{2}(1.5 \mathrm{M}$ in toluene, $2.0 \mathrm{~mL}, 3.0 \mathrm{mmol})$, and carbon dioxide (about $1 \mathrm{~L}$ ) in $10 \mathrm{~mL}$ of DMSO for $3 \mathrm{~h}$ afforded the crude product. The crude product was then reacted with $\mathrm{TMSCHN}_{2}(2.0 \mathrm{M}$ in hexane, $2.0 \mathrm{~mL}, 4.0 \mathrm{mmol})$ in 1 $\mathrm{mL}$ of $\mathrm{MeOH}$ and $4 \mathrm{~mL}$ of $\mathrm{Et}_{2} \mathrm{O}$ afforded $(Z, E)-3 \mathrm{~m}$ and 3m', the yields of which were determined by ${ }^{1} \mathrm{H}$ NMR analysis of the crude product using $\mathrm{CH}_{2} \mathrm{Br}_{2}$ as the internal standard (63\% and $2 \%$, respectively). $9 \%$ of the protonolysis product was also observed in the crude product. Pure $(Z, E)-3 \mathrm{~m}(238.9 \mathrm{mg}, 61 \%)$ was obtained via column chromatography on silica gel (eluent: hexane/ethyl acetate $=10 / 1$ ) as a white solid: m.p. 105-106 ${ }^{\circ} \mathrm{C}$ (petroleum ether/ethyl acetate); ${ }^{1} \mathrm{H}$ NMR (400 MHz, $\left.\mathrm{CDCl}_{3}\right) \delta$ 7.29-7.21 (m, $1 \mathrm{H}, \mathrm{ArH}), 6.88(\mathrm{~d}, J=7.2 \mathrm{~Hz}, 1 \mathrm{H}, \mathrm{ArH}), 6.84-6.77$ (m, $2 \mathrm{H}, \mathrm{ArH})$, $6.64(\mathrm{~s}, 1 \mathrm{H}, \mathrm{CH}=), 3.81\left(\mathrm{~s}, 3 \mathrm{H}, \mathrm{OCH}_{3}\right), 3.70\left(\mathrm{~s}, 9 \mathrm{H}, \mathrm{OCH}_{3} \times 3\right), 3.32\left(\mathrm{~s}, 2 \mathrm{H}, \mathrm{CH}_{2}\right)$, 3.07 (s, $\left.2 \mathrm{H}, \mathrm{CH}_{2}\right), 1.99$ (s, $\left.3 \mathrm{H}, \mathrm{CH}_{3}\right) ;{ }^{13} \mathrm{C} \mathrm{NMR}\left(100 \mathrm{MHz}, \mathrm{CDCl}_{3}\right) \delta$ 171.4, 171.2, $159.3,141.2,138.4,136.4,129.1,127.1,122.0,121.7,114.6,112.7,57.0,55.1,52.9$, 51.8, 39.3, 38.0, 18.3; MS (EI) (m/z) $388\left(\mathrm{M}^{+}, 15.43\right), 209$ (100); IR (neat, $\left.\mathrm{cm}^{-1}\right)$ 1730, $1706,1639,1596,1494,1460,1430,1380,1327,1303,1260,1209,1173,1133,1089$, 1071, 1042; Anal. calcd for $\mathrm{C}_{21} \mathrm{H}_{24} \mathrm{O}_{7}$ (\%): C 64.94, H 6.23; found: C 65.14, H 6.41.

$$
\text { Preparation of methyl (Z)-2-((E)-2-(4-methylphenylmethylene)-4,4- }
$$
bis(methoxycarbonyl)cyclopentylidene)propanoate $[(Z, E)-3 n]$ (ct-6-9) 


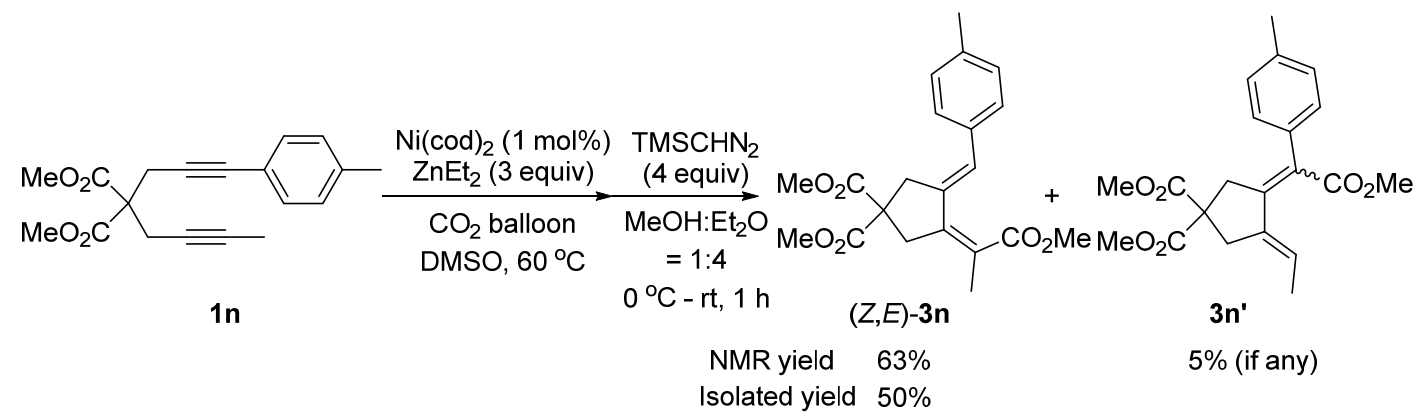

Following Typical Procedure: The reaction of $\mathrm{Ni}(\operatorname{cod})_{2}(2.9 \mathrm{mg}, 0.01 \mathrm{mmol})$, 1n $(312.0 \mathrm{mg}, 1.00 \mathrm{mmol}), \mathrm{ZnEt}_{2}(1.5 \mathrm{M}$ in toluene, $2.0 \mathrm{~mL}, 3.0 \mathrm{mmol})$, and carbon dioxide (about $1 \mathrm{~L}$ ) in $10 \mathrm{~mL}$ of DMSO for $3 \mathrm{~h}$ afforded the crude product. The crude product was then reacted with $\mathrm{TMSCHN}_{2}(2.0 \mathrm{M}$ in hexane, $2.0 \mathrm{~mL}, 4.0 \mathrm{mmol})$ in 1 $\mathrm{mL}$ of $\mathrm{MeOH}$ and $4 \mathrm{~mL}$ of $\mathrm{Et}_{2} \mathrm{O}$ afforded $(Z, E)-3 \mathbf{n}$ and $3 \mathbf{n}$, the yields of which were determined by ${ }^{1} \mathrm{H}$ NMR analysis of the crude product using $\mathrm{CH}_{2} \mathrm{Br}_{2}$ as the internal standard (63\% and $5 \%$, respectively). $14 \%$ of the protonolysis product was also observed in the crude product. $(Z, E)-3 \mathrm{n}(185.8 \mathrm{mg}, 50 \%)$ was obtained via column chromatography on silica gel (eluent: hexane/ethyl acetate $=15 / 1$ ) to afford an impure product and then recrystallization (hexane/ethyl acetate $=8 / 1$ ) to afford a pure product as a white solid: m.p. $83-84{ }^{\circ} \mathrm{C}$ (hexane/ethyl acetate); ${ }^{1} \mathrm{H}$ NMR $\left(400 \mathrm{MHz}, \mathrm{CDCl}_{3}\right) \delta$ $7.18(\mathrm{~d}, J=8.0 \mathrm{~Hz}, 2 \mathrm{H}, \mathrm{ArH}), 7.14(\mathrm{~d}, J=8.0 \mathrm{~Hz}, 2 \mathrm{H}, \mathrm{ArH}), 6.64(\mathrm{~s}, 1 \mathrm{H}, \mathrm{CH}=)$, $3.69\left(\mathrm{~s}, 6 \mathrm{H}, \mathrm{OCH}_{3} \times 2\right), 3.68\left(\mathrm{~s}, 3 \mathrm{H}, \mathrm{OCH}_{3}\right), 3.32\left(\mathrm{~s}, 2 \mathrm{H}, \mathrm{CH}_{2}\right), 3.06\left(\mathrm{~s}, 2 \mathrm{H}, \mathrm{CH}_{2}\right)$, $2.34\left(\mathrm{~s}, 3 \mathrm{H}, \mathrm{CH}_{3}\right), 1.98\left(\mathrm{~s}, 3 \mathrm{H}, \mathrm{CH}_{3}\right) ;{ }^{13} \mathrm{C} \mathrm{NMR}\left(100 \mathrm{MHz}, \mathrm{CDCl}_{3}\right) \delta$ 171.5, 171.4, $141.5,137.2$, 135.2, 134.2, 129.1, 128.9, 127.2, 121.4, 57.1, 52.9, 51.8, 39.3, 38.1, 21.2, 18.3; MS (EI) (m/z) $372\left(\mathrm{M}^{+}, 11.44\right), 193$ (100); IR (neat, $\left.\mathrm{cm}^{-1}\right)$ 1711, 1648, 1606, 1510, 1433, 1372, 1293, 1257, 1235, 1197, 1158, 1136, 1065, 1046; Anal. calcd for $\mathrm{C}_{21} \mathrm{H}_{24} \mathrm{O}_{6}(\%)$ : C 67.73, H 6.50; found: C 67.61, H 6.52.

(16) Preparation of methyl (Z)-2-((E)-2-(4-methoxycarbonylphenylmethylene)-4,4bis(methoxycarbonyl)cyclopentylidene)butanoate $[(Z, E)-30]($ ct-6-75) 


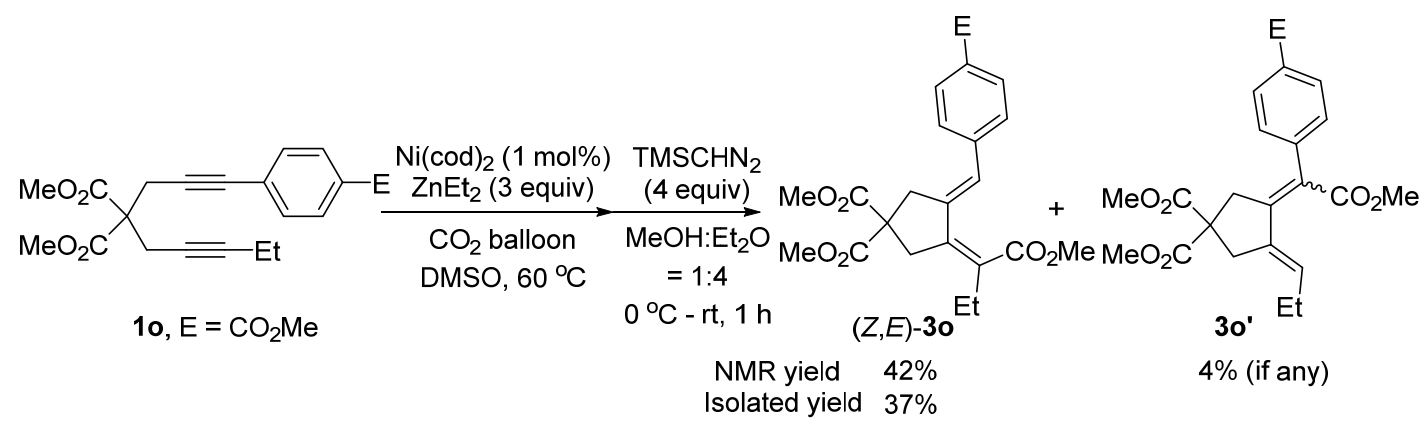

Following Typical Procedure: The reaction of $\mathrm{Ni}(\operatorname{cod})_{2}(2.8 \mathrm{mg}, 0.01 \mathrm{mmol})$, $10(371.0 \mathrm{mg}, 1.00 \mathrm{mmol}), \mathrm{ZnEt}_{2}(1.5 \mathrm{M}$ in toluene, $2.0 \mathrm{~mL}, 3.0 \mathrm{mmol})$, and carbon dioxide (about $1 \mathrm{~L}$ ) in $10 \mathrm{~mL}$ of DMSO for $3 \mathrm{~h}$ afforded the crude product. The crude product was then reacted with $\mathrm{TMSCHN}_{2}(2.0 \mathrm{M}$ in hexane, $2.0 \mathrm{~mL}, 4.0 \mathrm{mmol})$ in 1 $\mathrm{mL}$ of $\mathrm{MeOH}$ and $4 \mathrm{~mL}$ of $\mathrm{Et}_{2} \mathrm{O}$ afforded $(Z, E)$-3o and 3o', the yields of which were determined by ${ }^{1} \mathrm{H}$ NMR analysis of the crude product using $\mathrm{CH}_{2} \mathrm{Br}_{2}$ as the internal standard $(42 \%$ and $4 \%)$, respectively. $15 \%$ of the protonolysis product was also observed in the crude product. $(Z, E)$-3o $(160.6 \mathrm{mg}, 37 \%)$ was obtained via column chromatography on silica gel (eluent: hexane/ethyl acetate $=10 / 1)$ to afford an impure product and then recrystallization (hexane/ethyl acetate $=8 / 1$ ) to afford a pure product as a white solid: m.p. $88-89{ }^{\circ} \mathrm{C}$ (hexane/ethyl acetate); ${ }^{1} \mathrm{H}$ NMR $\left(400 \mathrm{MHz}, \mathrm{CDCl}_{3}\right) \delta$ $8.00(\mathrm{~d}, J=8.4 \mathrm{~Hz}, 2 \mathrm{H}, \mathrm{ArH}), 7.34(\mathrm{~d}, J=8.4 \mathrm{~Hz}, 2 \mathrm{H}, \mathrm{ArH}), 6.65(\mathrm{~s}, 1 \mathrm{H}, \mathrm{CH}=)$, $3.92\left(\mathrm{~s}, 3 \mathrm{H}, \mathrm{OCH}_{3}\right), 3.72\left(\mathrm{~s}, 3 \mathrm{H}, \mathrm{OCH}_{3}\right), 3.71\left(\mathrm{~s}, 6 \mathrm{H}, \mathrm{OCH}_{3} \times 2\right), 3.32(\mathrm{~d}, J=2.0 \mathrm{~Hz}$, $\left.2 \mathrm{H}, \mathrm{CH}_{2}\right), 3.10\left(\mathrm{~s}, 2 \mathrm{H}, \mathrm{CH}_{2}\right), 2.38\left(\mathrm{q}, J=7.5 \mathrm{~Hz}, 2 \mathrm{H}, \mathrm{CH}_{2}\right), 1.10(\mathrm{t}, J=7.6 \mathrm{~Hz}, 3 \mathrm{H}$, $\left.\mathrm{CH}_{3}\right) ;{ }^{13} \mathrm{C} \mathrm{NMR}\left(100 \mathrm{MHz}, \mathrm{CDCl}_{3}\right) \delta 171.2,170.9,166.7,141.5,139.0,138.8,129.6$, $129.5,128.8,128.5,125.5,57.1,53.0,52.0,51.8,39.2,37.2,26.0,12.0 ; \mathrm{MS}(\mathrm{EI})(\mathrm{m} / \mathrm{z})$ $430\left(\mathrm{M}^{+}, 36.81\right), 339$ (100); IR (neat, $\left.\mathrm{cm}^{-1}\right)$ 2950, 1738, 1712, 1647, 1603, 1561, 1429, $1273,1247,1181,1139,1118,1100,1073,1016$; Anal. calcd for $\mathrm{C}_{23} \mathrm{H}_{26} \mathrm{O}_{8}(\%)$ : C 64.18, H 6.09; found: C 64.14, H 6.09.

(17) Preparation of methyl (Z)-2-((E)-2-(3-methoxyphenylmethylene)-4,4,5,5tetrakis(ethoxycarbonyl)cyclohexylidene)propanoate $[(Z, E)-3 \mathbf{p}](\mathrm{ct}-7-132)$ 


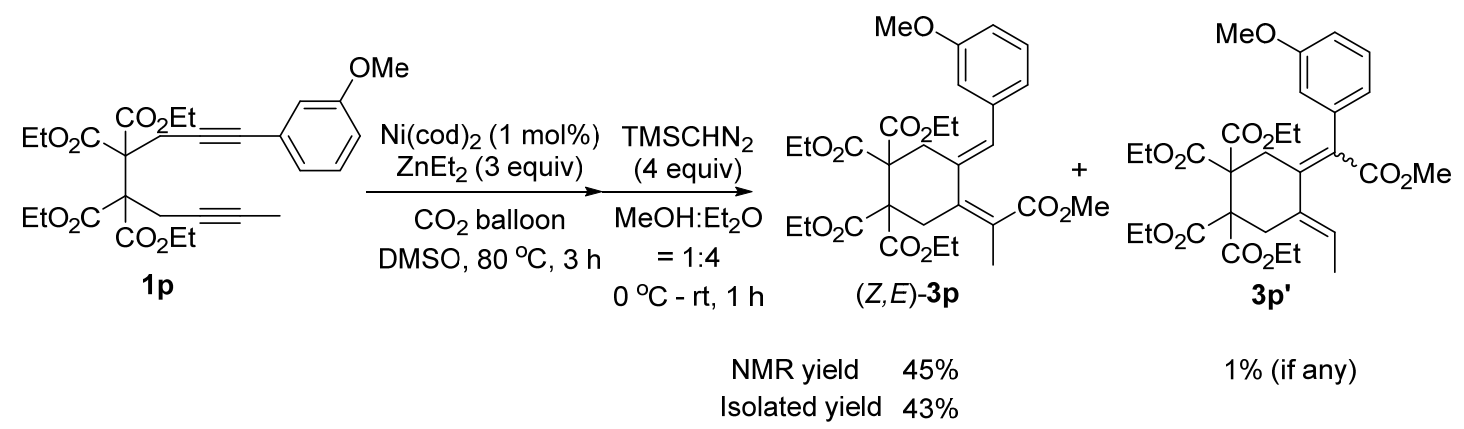

To a $25 \mathrm{~mL}$ flame-dried Schlenk tube was added $\mathrm{Ni}(\mathrm{cod})_{2}(0.8 \mathrm{mg}, 0.003 \mathrm{mmol})$ inside a glove box. Compound 1p (154.8 mg, $0.3 \mathrm{mmol})$ and DMSO (3 mL) were sequentially added under argon outside the glove box. The Schlenk tube was then frozen with a liquid nitrogen bath. The argon inside the tube was completely replaced with $\mathrm{CO}_{2}$ by using a balloon of $\mathrm{CO}_{2}$ (about $1 \mathrm{~L}$ ). The Schlenk tube was allowed to stand until the temperature was above $0{ }^{\circ} \mathrm{C}$. Then the Schlenk tube was placed in an oil bath pre-heated at $80{ }^{\circ} \mathrm{C}$. After completely thawed, to the mixture was added $\mathrm{ZnEt}_{2}$ (1.5 $\mathrm{M}$ in toluene, $0.6 \mathrm{~mL}, 0.9 \mathrm{mmol}$ ) with a syringe. After being vigorously stirred for $3 \mathrm{~h}$, the reaction was complete as monitored by TLC. $3 \mathrm{M} \mathrm{HCl}(5 \mathrm{~mL})$ was added to quench the reaction. The aqueous layer was extracted with EtOAc $(5 \mathrm{~mL} \times 3)$ and the combined organic layer was washed with brine $(10 \mathrm{~mL})$, dried over anhydrous $\mathrm{MgSO}_{4}$, filtered and concentrated in vacuo. To the crude product were added $\mathrm{MeOH}$ $(1 \mathrm{~mL})$ and $\mathrm{Et}_{2} \mathrm{O}(4 \mathrm{~mL})$ and the flask containing the mixture was placed in an ice bath. To the resulting mixture was dropwise added $\mathrm{TMSCHN}_{2}(2.0 \mathrm{M}$ in hexane, 0.6 $\mathrm{mL}, 1.2 \mathrm{mmol}$ ) with a syringe. After being stirred for $1 \mathrm{~h}$ at room temperature, the reaction was complete as monitored by TLC. The reaction mixture was concentrated and the yields of $(Z, E)$-3p and 3p' were determined by ${ }^{1} \mathrm{H}$ NMR analysis of the crude product using $\mathrm{CH}_{2} \mathrm{Br}_{2}$ as the internal standard (45\% and $1 \%$, respectively). (Z,E)-3p (74.4 mg, 43\%) was obtained via column chromatography on silica gel (eluent: petroleum ether/ethyl acetate $=6 / 1)$ as an oil: ${ }^{1} \mathrm{H}$ NMR $\left(400 \mathrm{MHz}, \mathrm{CDCl}_{3}, 20{ }^{\circ} \mathrm{C}\right) \delta$ 7.23 (t, $J=7.8 \mathrm{~Hz}, 1 \mathrm{H}, \mathrm{ArH}), 6.81-6.74(\mathrm{~m}, 2 \mathrm{H}, \mathrm{ArH}), 6.69$ (s, $1 \mathrm{H}, \mathrm{ArH}), 6.42$ (s, 1 $\mathrm{H}, \mathrm{CH}=), 4.23\left(\mathrm{q}, J=7.1 \mathrm{~Hz}, 4 \mathrm{H}, \mathrm{OCH}_{2} \times 2\right), 4.16-3.93\left(\mathrm{~m}, 4 \mathrm{H}, \mathrm{OCH}_{2} \times 2\right), 3.79(\mathrm{~s}$, $\left.3 \mathrm{H}, \mathrm{OCH}_{3}\right), 3.57\left(\mathrm{~s}, 3 \mathrm{H}, \mathrm{OCH}_{3}\right), 3.35$ (bs, $\left.2 \mathrm{H}, \mathrm{CH}_{2}\right), 3.14\left(\mathrm{~s}, 2 \mathrm{H}, \mathrm{CH}_{2}\right), 1.95(\mathrm{~s}, 3 \mathrm{H}$, $\left.\mathrm{CH}_{3}\right), 1.27\left(\mathrm{t}, J=7.2 \mathrm{~Hz}, 6 \mathrm{H}, \mathrm{CH}_{3} \times 2\right), 1.18-1.02\left(\mathrm{~m}, 6 \mathrm{H}, \mathrm{CH}_{3} \times 2\right) ;{ }^{1} \mathrm{H} \mathrm{NMR}(600$ 
$\left.\mathrm{MHz}, \mathrm{CDCl}_{3}, 60{ }^{\circ} \mathrm{C}\right) \delta 7.20(\mathrm{t}, J=7.8 \mathrm{~Hz}, 1 \mathrm{H}, \mathrm{ArH}), 6.77-6.74(\mathrm{~m}, 2 \mathrm{H}, \mathrm{ArH}), 6.70$ (s, $1 \mathrm{H}, \mathrm{ArH}), 6.41(\mathrm{~s}, 1 \mathrm{H}, \mathrm{CH}=)$, 4.24-4.18 (m, $\left.4 \mathrm{H}, \mathrm{OCH}_{2} \times 2\right), 4.15-4.00(\mathrm{~m}, 4 \mathrm{H}$, $\left.\mathrm{OCH}_{2} \times 2\right), 3.78\left(\mathrm{~s}, 3 \mathrm{H}, \mathrm{OCH}_{3}\right), 3.57\left(\mathrm{~s}, 3 \mathrm{H}, \mathrm{OCH}_{3}\right), 3.33\left(\mathrm{~s}, 2 \mathrm{H}, \mathrm{CH}_{2}\right), 3.16(\mathrm{~s}, 2 \mathrm{H}$, $\left.\mathrm{CH}_{2}\right), 1.94\left(\mathrm{~s}, 3 \mathrm{H}, \mathrm{CH}_{3}\right), 1.26\left(\mathrm{t}, J=7.2 \mathrm{~Hz}, 6 \mathrm{H}, \mathrm{CH}_{3} \times 2\right), 1.11(\mathrm{t}, J=7.2 \mathrm{~Hz}, 6 \mathrm{H}$, $\left.\mathrm{CH}_{3} \times 2\right) ;{ }^{13} \mathrm{C} \mathrm{NMR}\left(100 \mathrm{MHz}, \mathrm{CDCl}_{3}\right) \delta 172.1,169.2,159.3,140.3,137.9,136.4$, 129.1, 128.8, 126.4, 121.4, 114.4, 112.5, 61.8, 61.7, 59.6, 59.4, 55.1, 51.6, 33.3, 33.0, 15.9, 13.7, 13.5; MS (EI) (m/z) $574\left(\mathrm{M}^{+}, 22.75\right), 367$ (100); IR (neat, $\left.\mathrm{cm}^{-1}\right)$ 2985, 2947, 2845, 1726, 1589, 1441, 1374, 1258, 1196, 1096, 1041; HRMS calcd for $\mathrm{C}_{30} \mathrm{H}_{38} \mathrm{O}_{11}\left(\mathrm{M}^{+}\right)$: 574.2414; found: 574.2420.

$$
\text { Preparation of } \quad(E)-2-((E)-2-e t h y l i d e n e-4,4-b i s(m e t h o x y c a r b o n y l)
$$

cyclopentylidene) propanoic acid $[(E, E)-2 \mathbf{a}](\mathrm{ct}-5-55)$

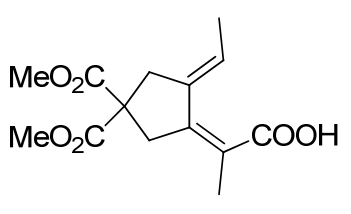

$(Z, E)-\mathbf{2 a}$

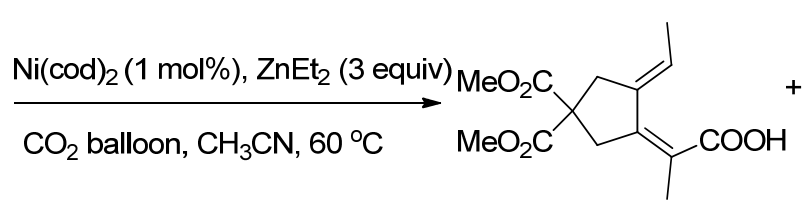

(Z,E)-2a

$13 \%$

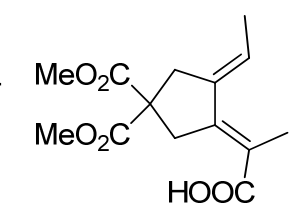

$(E, E)-2 a$
$71 \%$

To a $25 \mathrm{~mL}$ flame-dried Schlenk tube was added $\mathrm{Ni}(\operatorname{cod})_{2}(0.8 \mathrm{mg}, 0.003 \mathrm{mmol})$ inside a glove box. Compound $(Z, E)-2 \mathrm{a}(84.1 \mathrm{mg}, 0.30 \mathrm{mmol})$ and $\mathrm{CH}_{3} \mathrm{CN}(3 \mathrm{~mL})$ were sequentially added under argon outside the glove box. The Schlenk tube was then frozen with a liquid nitrogen bath. The argon inside the tube was completely replaced with $\mathrm{CO}_{2}$ by using a balloon of $\mathrm{CO}_{2}$ (about $1 \mathrm{~L}$ ). The Schlenk tube was allowed to stand until the temperature was above $0{ }^{\circ} \mathrm{C}$. Then the Schlenck tube was placed in an oil bath pre-heated at $60{ }^{\circ} \mathrm{C}$. After completely thawed, to the mixture was added $\mathrm{ZnEt}_{2}(1.5 \mathrm{M}$ in toluene, $0.6 \mathrm{~mL}, 0.9 \mathrm{mmol})$ with a syringe. After being vigorously stirred for $3 \mathrm{~h}$, the reaction was complete as monitored by TLC. $3 \mathrm{M} \mathrm{HCl}$ $(5 \mathrm{~mL})$ was added to quench the reaction. The aqueous layer was extracted with EtOAc $(5 \mathrm{~mL} \times 3)$ and the combined organic layer was washed with brine $(10 \mathrm{~mL})$, dried over anhydrous $\mathrm{MgSO}_{4}$, filtered and concentrated in vacuo. The yield of $(E, E)$-2a and remaining of $(Z, E)-2 \mathbf{a}$ were $71 \%$ and $13 \%$, respectively as determined 
by ${ }^{1} \mathrm{H}$ NMR analysis of the crude product using $\mathrm{CH}_{2} \mathrm{Br}_{2}$ as the internal standard. Pure $(E, E)-2 a(43.5 \mathrm{mg}, 52 \%)$ was obtained via recrystallization (petroleum ether/ethyl acetate) of the crude product as a white solid: m.p. $167-168^{\circ} \mathrm{C}$ (petroleum ether/ethyl acetate); ${ }^{1} \mathrm{H}$ NMR (400 MHz, $\left.\mathrm{CDCl}_{3}\right) \delta 12.52$ (s, $\left.1 \mathrm{H}, \mathrm{COOH}\right), 6.07$ (q, $J=6.9 \mathrm{~Hz}, 1$ $\mathrm{H}, \mathrm{CH}=), 3.75\left(\mathrm{~s}, 6 \mathrm{H}, \mathrm{OCH}_{3} \times 2\right), 3.53\left(\mathrm{~s}, 2 \mathrm{H}, \mathrm{CH}_{2}\right), 3.01\left(\mathrm{~s}, 2 \mathrm{H}, \mathrm{CH}_{2}\right), 2.12(\mathrm{~s}, 3 \mathrm{H}$, $\left.\mathrm{CH}_{3}\right), 1.84\left(\mathrm{~d}, J=6.8 \mathrm{~Hz}, 3 \mathrm{H}, \mathrm{CH}_{3}\right) ;{ }^{13} \mathrm{C} \mathrm{NMR}\left(100 \mathrm{MHz}, \mathrm{CDCl}_{3}\right) \delta$ 174.6, 171.9, 151.0, 139.2, 129.7, 120.2, 57.0, 52.9, 42.0, 37.0, 17.3, 15.9; MS (EI) (m/z) $282\left(\mathrm{M}^{+}\right.$, 43.95), 117 (100); IR (neat, $\mathrm{cm}^{-1}$ ) 2957-2535, 1730, 1662, 1574, 1454, 1432, 1413, $1373,1346,1276,1229,1207,1163,1125,1105,1080,1058$; Anal. calcd for $\mathrm{C}_{14} \mathrm{H}_{18} \mathrm{O}_{6}(\%)$ : C 59.57, H 6.43; found: C 59.67, H 6.61.

ORTEP representation of $(E, E)-\mathbf{2 a}$ :

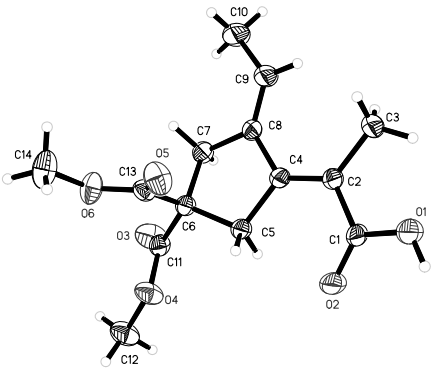

Crystal data for compound $(E, E)-2 \mathrm{a}: \mathrm{C}_{14} \mathrm{H}_{18} \mathrm{O}_{6}, \mathrm{MW}=282.28$, Triclinic, space group $P$-1, final $\mathrm{R}$ indices $[I>2 \sigma(I)], R 1=0.0518, w R 2=0.1436 ; R$ indices (all data), $R 1=0.0640, w R 2=0.1558 ; a=7.9442(11) \AA, b=9.3857(12) \AA, c=10.6485(15) \AA$, $\alpha=68.342(3)^{\circ}, \beta=77.473(3)^{\circ}, \gamma=84.276(3)^{\circ}, V=720.18(17) \AA^{3}, T=293(2) \mathrm{K}, Z=$ 2 , reflections collected/unique 4409/2820 $($ Rint $=0.0228)$, number of observations [ $>$ $2 \sigma(I)]$ 2820, parameters: 198. Supplementary crystallographic data have been deposited at the Cambridge Crystallographic Data Centre, CCDC 1005263.

(19) Preparation of methyl (E)-2-((E)-2-ethylidene-4,4-bis(methoxycarbonyl) cyclopentylidene)propanoate $[(E, E)-3 a](\mathrm{ct}-5-123)$ 


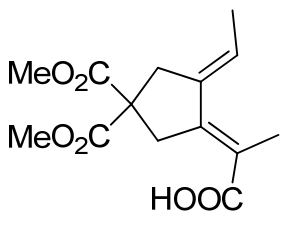

$(E, E)-\mathbf{2 a}$

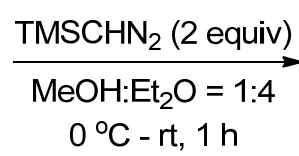

$0^{\circ} \mathrm{C}-\mathrm{rt}, 1 \mathrm{~h}$

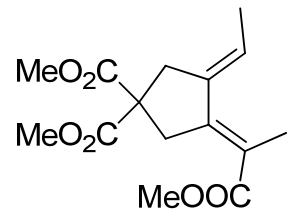

$(E, E)-\mathbf{3 a}, \mathbf{9 2} \%$

To a flask was added (E,E)-2a $(56.1 \mathrm{mg}, 0.20 \mathrm{mmol}), 1 \mathrm{~mL}$ of $\mathrm{MeOH}$ and $4 \mathrm{~mL}$ of $\mathrm{Et}_{2} \mathrm{O}$. Then $\mathrm{TMSCHN}_{2}(2.0 \mathrm{M}$ in hexane, $0.2 \mathrm{~mL}, 0.4 \mathrm{mmol})$ was dropwise added at $0{ }^{\circ} \mathrm{C}$ with a syringe. The reaction mixture was reacted for $1 \mathrm{~h}$ at room temperature followed by concentration in vacuo. The crude product was purified by column chromatography on silica gel to afford (E,E)-3a (53.9 mg, 92\%) (eluent: hexane/ethyl acetate $=10 / 1)$ as an oil: ${ }^{1} \mathrm{H}$ NMR $\left(400 \mathrm{MHz}, \mathrm{CDCl}_{3}\right) \delta 6.00(\mathrm{q}, J=6.8 \mathrm{~Hz}, 1 \mathrm{H}$, $\mathrm{CH}=), 3.75\left(\mathrm{~s}, 3 \mathrm{H}, \mathrm{OCH}_{3}\right), 3.73\left(\mathrm{~s}, 6 \mathrm{H}, \mathrm{OCH}_{3} \times 2\right), 3.45\left(\mathrm{~s}, 2 \mathrm{H}, \mathrm{CH}_{2}\right), 3.00(\mathrm{~s}, 2 \mathrm{H}$, $\left.\mathrm{CH}_{2}\right), 2.09\left(\mathrm{~s}, 3 \mathrm{H},=\mathrm{C}(\mathrm{CO}) \mathrm{CH}_{3}\right), 1.82\left(\mathrm{~d}, J=6.8 \mathrm{~Hz}, 3 \mathrm{H}, \mathrm{CH}_{3}\right) ;{ }^{13} \mathrm{C} \mathrm{NMR}(100 \mathrm{MHz}$, $\left.\mathrm{CDCl}_{3}\right) \delta 171.8,169.4,147.9,138.8,128.4,120.7,57.0,52.8,51.5,41.7,37.1,17.4$, 15.7; MS (EI) (m/z) $296\left(\mathrm{M}^{+}, 40.16\right), 205$ (100); IR (neat, $\left.\mathrm{cm}^{-1}\right)$ 1730, 1693, 1594, 1433, 1371, 1347, 1290, 1263, 1209, 1167, 1148, 1123, 1102, 1080, 1055; HRMS calcd for $\mathrm{C}_{15} \mathrm{H}_{20} \mathrm{O}_{6}\left(\mathrm{M}^{+}\right)$: 296.1260; found: 296.1261.

\section{Control experiments.}

(1) Hydrocarboxylation of 6. (ct-5-34)

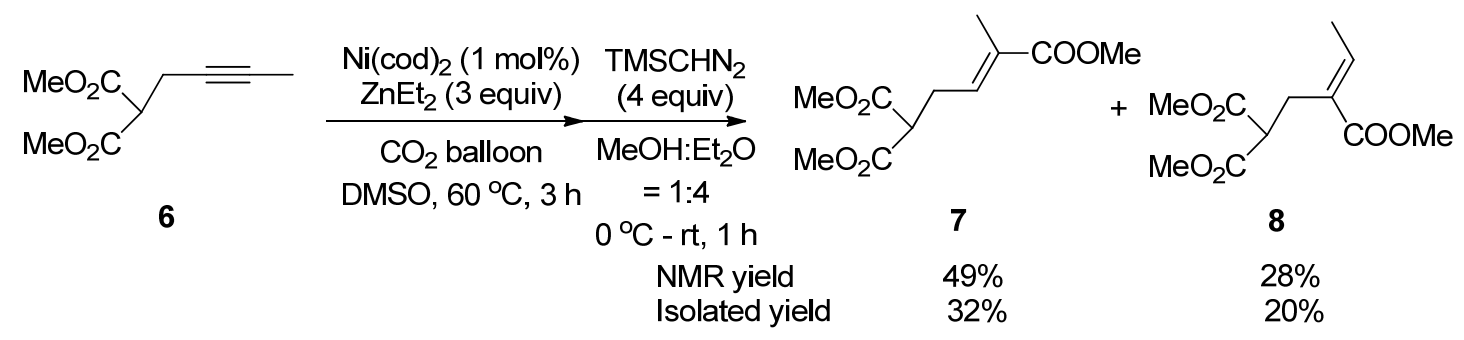

Following Typical Procedure: The reaction of $\mathrm{Ni}(\operatorname{cod})_{2}(1.4 \mathrm{mg}, 0.005 \mathrm{mmol})$, 6 (91.7 mg, $0.50 \mathrm{mmol}), \mathrm{ZnEt}_{2}(1.5 \mathrm{M}$ in toluene, $1.0 \mathrm{~mL}, 1.5 \mathrm{mmol}$ ), and carbon dioxide (about $1 \mathrm{~L}$ ) in $5 \mathrm{~mL}$ of DMSO for $3 \mathrm{~h}$ afforded the crude product. The crude product was then reacted with $\mathrm{TMSCHN}_{2}(2.0 \mathrm{M}$ in hexane, $1.0 \mathrm{~mL}, 2.0 \mathrm{mmol})$ in 1 $\mathrm{mL}$ of $\mathrm{MeOH}$ and $4 \mathrm{~mL}$ of $\mathrm{Et}_{2} \mathrm{O}$ for $1 \mathrm{~h}$ afforded 7 and $\mathbf{8}$, with the ratio of 1.8:1 determined by ${ }^{1} \mathrm{H}$ NMR analysis of the crude product. Pure 7 (39.5 mg, 32\%) and $\mathbf{8}^{8}$ (24.0 mg, 20\%) were obtained via column chromatography on silica gel (eluent: 
hexane/ethyl acetate $=15 / 1$ for the first round to provide $24.0 \mathrm{mg}$ of 8 and $50.1 \mathrm{mg}$ of impure 7; and the impure 7 was submitted to second round column chromatography on silica gel with eluent of hexane/diethyl ether $=10 / 1$ to provide $39.5 \mathrm{mg}$ of pure 7).

7: more polar, oil; ${ }^{1} \mathrm{H} \mathrm{NMR}\left(400 \mathrm{MHz}, \mathrm{CDCl}_{3}\right) \delta 6.65(\mathrm{t}, J=7.4 \mathrm{~Hz}, 1 \mathrm{H}, \mathrm{CH}=)$, $3.76\left(\mathrm{~s}, 6 \mathrm{H}, \mathrm{OCH}_{3} \times 2\right), 3.73\left(\mathrm{~s}, 3 \mathrm{H}, \mathrm{OCH}_{3}\right), 3.51$ (t, $\left.J=7.4 \mathrm{~Hz}, 1 \mathrm{H}, \mathrm{CH}\right), 2.79$ (t, $J$

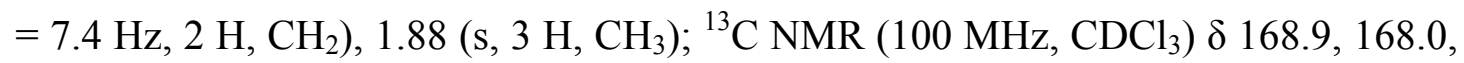
136.6, 130.3, 52.7, 51.8, 50.5, 27.9, 12.4; MS (ESI) (m/z) $262\left(\left[\mathrm{M}+\mathrm{NH}_{4}\right]^{+}\right)$; IR (neat, $\left.\mathrm{cm}^{-1}\right)$ 2959, 1734, 1712, 1653, 1436, 1337, 1259, 1233, 1193, 1156, 1123, 1085, 1024; HRMS calcd for $\mathrm{C}_{11} \mathrm{H}_{20} \mathrm{NO}_{6}\left(\left[\mathrm{M}+\mathrm{NH}_{4}\right]^{+}\right): 262.1285$; found: 262.1277 .

$8^{8}$ : less polar, oil; ${ }^{1} \mathrm{H}$ NMR (400 MHz, $\left.\mathrm{CDCl}_{3}\right) \delta 7.00$ (q, $\left.J=7.2 \mathrm{~Hz}, 1 \mathrm{H}, \mathrm{CH}=\right)$, $3.75(\mathrm{t}, J=7.8 \mathrm{~Hz}, 1 \mathrm{H}, \mathrm{CH}), 3.74\left(\mathrm{~s}, 3 \mathrm{H}, \mathrm{OCH}_{3}\right), 3.72\left(\mathrm{~s}, 6 \mathrm{H}, \mathrm{OCH}_{3} \times 2\right), 2.92(\mathrm{~d}, J$ $\left.=8.0 \mathrm{~Hz}, 2 \mathrm{H}, \mathrm{CH}_{2}\right), 1.84\left(\mathrm{~d}, J=7.2 \mathrm{~Hz}, 3 \mathrm{H}, \mathrm{CH}_{3}\right) ;{ }^{13} \mathrm{C} \mathrm{NMR}\left(75 \mathrm{MHz}, \mathrm{CDCl}_{3}\right) \delta$ $169.4,167.3,141.3,128.5,52.5,51.8,50.4,25.8,14.4 ;$ MS (ESI) (m/z) 262 $\left(\left[\mathrm{M}+\mathrm{NH}_{4}\right]^{+}\right)$; IR (neat, $\left.\mathrm{cm}^{-1}\right)$ 2959, 1735, 1710, 1650, 1436, 1386, 1335, 1261, 1236, 1196, 1151, 1131, 1056, 1026.

(2) Hydrocarboxylation of 9 (ct-8-18)

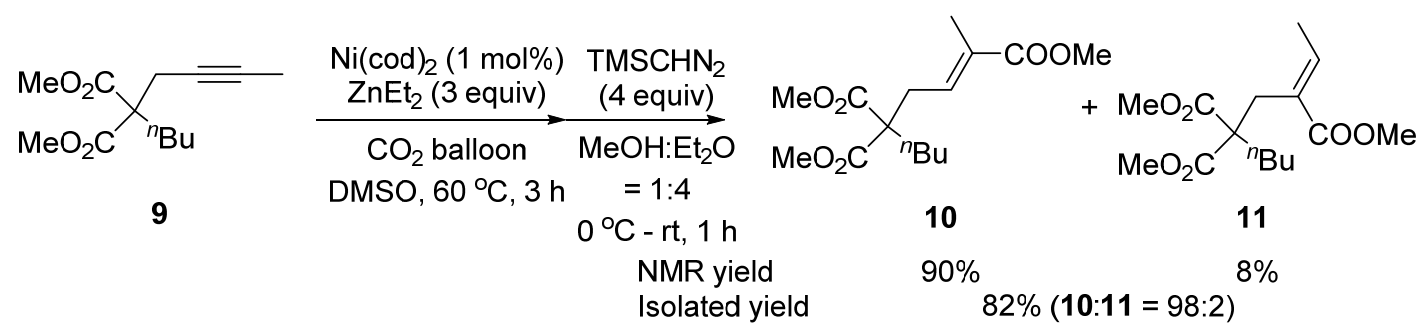

Following Typical Procedure: The reaction of $\mathrm{Ni}(\mathrm{cod})_{2}(1.4 \mathrm{mg}, 0.005 \mathrm{mmol})$, 9 (120.8 $\mathrm{mg}, 0.50 \mathrm{mmol}), \mathrm{ZnEt}_{2}(1.5 \mathrm{M}$ in toluene, $1.0 \mathrm{~mL}, 1.5 \mathrm{mmol})$, and carbon dioxide (about $1 \mathrm{~L}$ ) in $5 \mathrm{~mL}$ of DMSO for $3 \mathrm{~h}$ afforded the crude product. The crude product was then reacted with $\mathrm{TMSCHN}_{2}(2.0 \mathrm{M}$ in hexane, $1.0 \mathrm{~mL}, 2.0 \mathrm{mmol})$ in 1 $\mathrm{mL}$ of $\mathrm{MeOH}$ and $4 \mathrm{~mL}$ of $\mathrm{Et}_{2} \mathrm{O}$ for $1 \mathrm{~h}$ afforded $\mathbf{1 0}$ and 11, with the ratio of 11:1 determined by ${ }^{1} \mathrm{H}$ NMR analysis of the crude product. A mixture of $\mathbf{1 0}$ and $\mathbf{1 1}$ (124.4 $\mathrm{mg}, 82 \%, \mathbf{1 0 : 1 1}=98: 2$ ) was obtained via column chromatography on silica gel (eluent: petroleum ether/diethyl ether $=10 / 1$ ) as an oil. 
10: ${ }^{1} \mathrm{H}$ NMR (400 MHz, $\left.\mathrm{CDCl}_{3}\right) \delta 6.59(\mathrm{t}, J=7.4 \mathrm{~Hz}, 1 \mathrm{H}, \mathrm{CH}=), 3.73(\mathrm{~s}, 9 \mathrm{H}$, $\left.\mathrm{OCH}_{3} \times 3\right), 2.79\left(\mathrm{~d}, J=7.6 \mathrm{~Hz}, 2 \mathrm{H}, \mathrm{CH}_{2}\right), 1.94-1.81\left(\mathrm{~m}, 5 \mathrm{H}, \mathrm{CH}_{2}+\mathrm{CH}_{3}\right), 1.38-1.24$ $\left(\mathrm{m}, 2 \mathrm{H}, \mathrm{CH}_{2}\right), 1.21-1.09\left(\mathrm{~m}, 2 \mathrm{H}, \mathrm{CH}_{2}\right), 0.89\left(\mathrm{t}, J=7.2 \mathrm{~Hz}, 3 \mathrm{H}, \mathrm{CH}_{3}\right) ;{ }^{13} \mathrm{C} \mathrm{NMR}$ $\left(100 \mathrm{MHz}, \mathrm{CDCl}_{3}\right) \delta 171.5,168.0,135.3,130.5,57.1,52.5,51.8,32.4,31.7,26.2$, 22.7, 13.8, 12.5; GC-MS (GC condition: injector: $260{ }^{\circ} \mathrm{C}$; column: DB-5MS column $30 \mathrm{~m} \times 0.25 \mathrm{~mm}$, temperature programming: $15{ }^{\circ} \mathrm{C} / \mathrm{min}$ to $285{ }^{\circ} \mathrm{C}, 285{ }^{\circ} \mathrm{C}(15 \mathrm{~min})$; detector: $\left.150{ }^{\circ} \mathrm{C}\right)(70 \mathrm{ev}, \mathrm{EI})(\mathrm{m} / \mathrm{z})$ (retention time: $\left.12.0 \mathrm{~min}\right): 300\left(\mathrm{M}^{+}, 1.14\right), 181$ (100); IR (neat, $\mathrm{cm}^{-1}$ ) 2996, 2956, 2873, 1732, 1652, 1435, 1388, 1365, 1260, 1209, 1146, 1123, 1084, 1048, 1028; HRMS calcd for $\mathrm{C}_{15} \mathrm{H}_{24} \mathrm{O}_{6}\left(\mathrm{M}^{+}\right)$: 300.1573; found: 300.1571 .

The following signals are discernible for 11: ${ }^{1} \mathrm{H}$ NMR (400 MHz, $\left.\mathrm{CDCl}_{3}\right) \delta 6.92$ (q, $J=7.3 \mathrm{~Hz}, 1 \mathrm{H}, \mathrm{CH}=$ ); GC-MS (GC condition: injector: $260{ }^{\circ} \mathrm{C}$; column: DB-5MS column $30 \mathrm{~m} \times 0.25 \mathrm{~mm}$, temperature programming: $15^{\circ} \mathrm{C} / \mathrm{min}$ to $285^{\circ} \mathrm{C}, 285{ }^{\circ} \mathrm{C}(15$ $\mathrm{min})$; detector: $\left.150{ }^{\circ} \mathrm{C}\right)(70 \mathrm{ev}, \mathrm{EI})(\mathrm{m} / \mathrm{z})$ (retention time: $\left.11.8 \mathrm{~min}\right): 300\left(\mathrm{M}^{+}, 1.93\right)$, 209 (100); HRMS calcd for $\mathrm{C}_{15} \mathrm{H}_{24} \mathrm{O}_{6}\left(\mathrm{M}^{+}\right)$: 300.1573 ; found: 300.1568 .

(3) Preparation of $(Z)-2-((E)$-2-ethylidenecyclopentylidene)propanoate $[(Z, E)$-3q $]$ (ct-7-160)

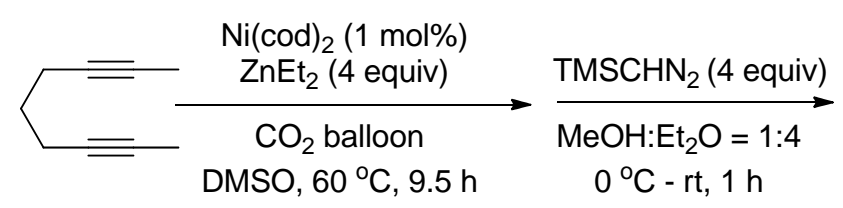

$1 q$

$$
\begin{aligned}
& \text { NMR yield: } \\
& \text { Isolated yield: }
\end{aligned}
$$

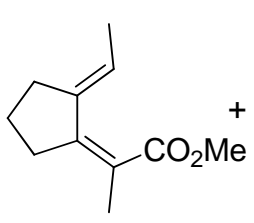

$(Z, E)-3 q$

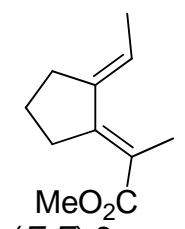

$(E, E)-\mathbf{3 q}$
$2 \%$

To a $25 \mathrm{~mL}$ flame-dried Schlenk tube was added compound 1q (purity of 90\%, $67.0 \mathrm{mg}, 0.5 \mathrm{mmol})$, DMSO $(5 \mathrm{~mL})$ and $\mathrm{ZnEt}_{2}(1.5 \mathrm{M}$ in toluene, $1.33 \mathrm{~mL}, 2.0 \mathrm{mmol})$ under argon. Then the Schlenk tube was moved to a glovebox and Ni(cod) $)_{2}(1.4 \mathrm{mg}$, $0.005 \mathrm{mmol}$ ) was added. After being moved out of the glovebox, the Schlenk tube was frozen with a liquid nitrogen bath. The argon inside the tube was completely replaced with $\mathrm{CO}_{2}$ by using a balloon of $\mathrm{CO}_{2}$ (about $1 \mathrm{~L}$ ). The Schlenk tube was allowed to stand until the temperature was above $0{ }^{\circ} \mathrm{C}$. Then the Schlenk tube was 
placed in an oil bath pre-heated at $60{ }^{\circ} \mathrm{C}$. After being vigorously stirred for $9.5 \mathrm{~h}$, the reaction was complete as monitored by TLC. $3 \mathrm{M} \mathrm{HCl}(5 \mathrm{~mL})$ was added to quench the reaction. The aqueous layer was extracted with EtOAc $(5 \mathrm{~mL} \times 3)$ and the combined organic layer was washed with brine $(10 \mathrm{~mL})$, dried over anhydrous $\mathrm{MgSO}_{4}$, filtered and concentrated in vacuo. To the crude product were added $\mathrm{MeOH}$ $(1 \mathrm{~mL})$ and $\mathrm{Et}_{2} \mathrm{O}(4 \mathrm{~mL})$ and the flask containing the mixture was placed in an ice bath. To the resulting mixture was dropwise added $\mathrm{TMSCHN}_{2}(2.0 \mathrm{M}$ in hexane, 1.0 $\mathrm{mL}, 2.0 \mathrm{mmol}$ ) with a syringe. After being stirred for $1 \mathrm{~h}$ at room temperature, the reaction was complete as monitored by TLC. The reaction mixture was concentrated and the ratio of $(Z, E)-\mathbf{3 q} /(E, E)$-3q was determined by ${ }^{1} \mathrm{H}$ NMR analysis of the crude product to be $96: 4$. (Z,E)-3q $(45.0 \mathrm{mg}, 50 \%)$ was obtained via column chromatography on silica gel (eluent: petroleum ether/diethyl ether $=30 / 1$ ) as an oil: ${ }^{1} \mathrm{H}$ NMR (400 MHz, $\left.\mathrm{CDCl}_{3}\right) \delta 5.71$ (q, $\left.J=6.9 \mathrm{~Hz}, 1 \mathrm{H}, \mathrm{CH}=\right), 3.73\left(\mathrm{~s}, 3 \mathrm{H}, \mathrm{OCH}_{3}\right)$, 2.39 (t, $\left.J=7.0 \mathrm{~Hz}, 4 \mathrm{H}, \mathrm{CH}_{2} \times 2\right), 1.90\left(\mathrm{~s}, 3 \mathrm{H}, \mathrm{CH}_{3}\right), 1.76-1.67\left(\mathrm{~m}, 5 \mathrm{H}, \mathrm{CH}_{2}+\mathrm{CH}_{3}\right)$; ${ }^{13} \mathrm{C}$ NMR $\left(100 \mathrm{MHz}, \mathrm{CDCl}_{3}\right) \delta 172.2,143.7,139.4,120.4,118.4,51.6,32.1,30.1$, 22.5, 18.2, 15.6; MS (EI) (m/z) $180\left(\mathrm{M}^{+}, 28.81\right), 165$ (100); IR (neat, $\left.\mathrm{cm}^{-1}\right)$ 2951, 1718, 1653, 1438, 1272, 1197, 1145, 1094; HRMS calcd for $\mathrm{C}_{11} \mathrm{H}_{16} \mathrm{O}_{2}\left(\mathrm{M}^{+}\right): 180.1150$; found: 180.1149 .

(4) Reaction of $1 \mathbf{a}$ and $\mathrm{Ni}(\mathrm{cod})_{2} \cdot($ ct-4-126)

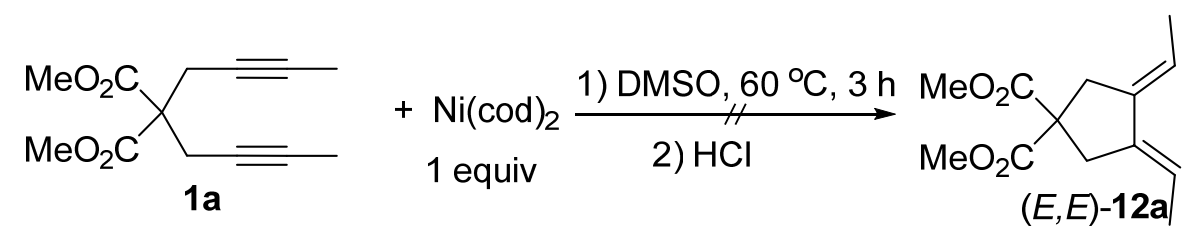

To a $25 \mathrm{~mL}$ flame-dried Schlenk tube was added Ni(cod) $2(55.1 \mathrm{mg}, 0.20 \mathrm{mmol})$ inside a glove box. Compound 1a $(47.6 \mathrm{mg}, 0.20 \mathrm{mmol})$ and DMSO $(2 \mathrm{~mL})$ were sequentially added under argon outside the glove box. Then the Schlenck tube was placed in an oil bath pre-heated at $60{ }^{\circ} \mathrm{C}$ and reacted for $3 \mathrm{~h} .3 \mathrm{M} \mathrm{HCl}(5 \mathrm{~mL})$ was added to quench the reaction. The aqueous layer was extracted with EtOAc $(5 \mathrm{~mL} \times 3)$ and the combined organic layer was washed with brine $(10 \mathrm{~mL})$, dried over anhydrous 
$\mathrm{MgSO}_{4}$, filtered and concentrated in vacuo to afford a complicated mixture; $(E, E)-12 \mathrm{a}$ was not observed by ${ }^{1} \mathrm{H}$ NMR analysis of the crude product.

(5) Reaction of 1a without carbon dioxide. (ct-4-127, ct-4-132)

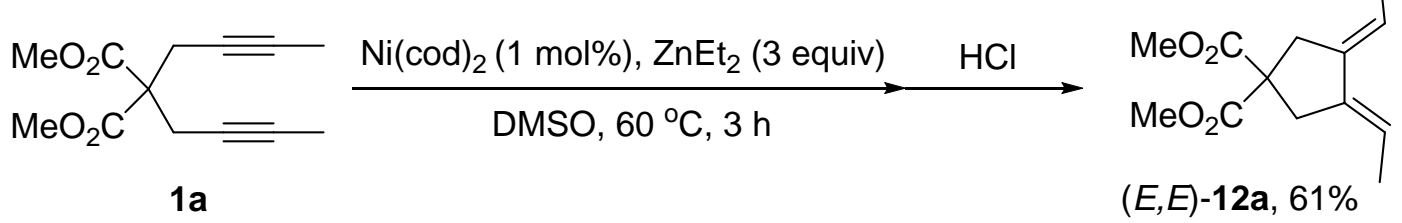

To a $25 \mathrm{~mL}$ flame-dried Schlenk tube was added Ni(cod $)_{2}(1.4 \mathrm{mg}, 0.005 \mathrm{mmol})$ inside a glove box. Compound 1a (118.2 mg, $0.50 \mathrm{mmol})$ and DMSO (5 mL) were sequentially added under argon outside the glove box. Then the Schlenck tube was placed in an oil bath pre-heated at $60{ }^{\circ} \mathrm{C}$. To the mixture was added $\mathrm{ZnEt}_{2}(1.5 \mathrm{M}$ in toluene, $1.0 \mathrm{~mL}, 1.5 \mathrm{mmol}$ ) with a syringe. After being vigorously stirred for $3 \mathrm{~h}$, the reaction was complete as monitored by TLC. $3 \mathrm{M} \mathrm{HCl}(5 \mathrm{~mL})$ was added to quench the reaction. The aqueous layer was extracted with EtOAc $(5 \mathrm{~mL} \times 3)$ and the combined organic layer was washed with brine $(10 \mathrm{~mL})$, dried over anhydrous $\mathrm{MgSO}_{4}$, filtered and concentrated in vacuo to afford $(E, E)-\mathbf{1 2 a} \mathbf{a}^{9}(72.2 \mathrm{mg}, 61 \%)$ via column chromatography on silica gel (eluent: petroleum ether/ethyl acetate $=10 / 1$ ) as an oil: ${ }^{1} \mathrm{H}$ NMR (400 MHz, $\left.\mathrm{CDCl}_{3}\right) \delta 5.77(\mathrm{q}, J=6.8 \mathrm{~Hz}, 2 \mathrm{H}, \mathrm{CH}=), 3.74(\mathrm{~s}, 6 \mathrm{H}$, $\left.\mathrm{OCH}_{3} \times 2\right), 2.97\left(\mathrm{~s}, 4 \mathrm{H}, \mathrm{CH}_{2} \times 2\right), 1.70\left(\mathrm{~d}, J=6.8 \mathrm{~Hz}, 6 \mathrm{H}, \mathrm{CH}_{3} \times 2\right) ;{ }^{13} \mathrm{C} \mathrm{NMR}(100$ $\left.\mathrm{MHz}, \mathrm{CDCl}_{3}\right) \delta 172.1,137.4,113.6,57.5,52.8,37.6,14.7$; MS (EI) (m/z) $238\left([\mathrm{M}]^{+}\right.$, 26.11), 119 (100); IR (neat, $\mathrm{cm}^{-1}$ ) 1731, 1435, 1369, 1256, 1199, 1162, 1100, 1066, 1037.

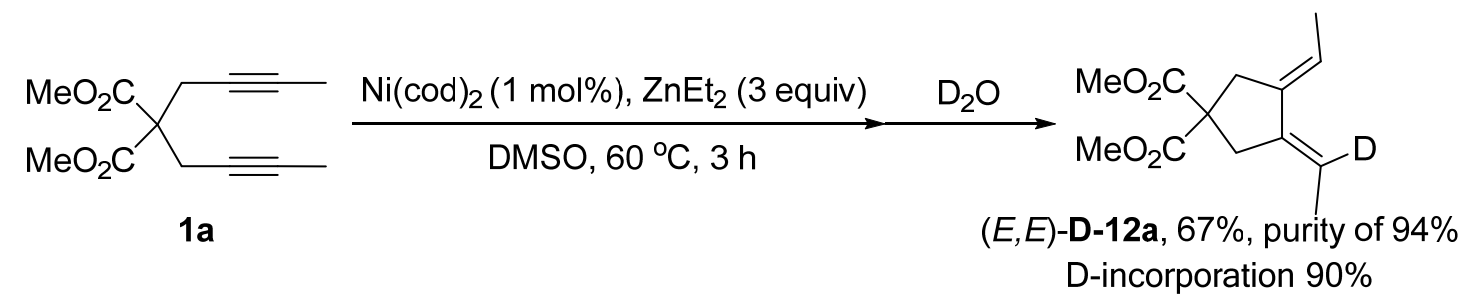

To a $25 \mathrm{~mL}$ flame-dried Schlenk tube was added Ni(cod $)_{2}(1.4 \mathrm{mg}, 0.005 \mathrm{mmol})$ inside a glove box. Compound 1a $(118.3 \mathrm{mg}, 0.50 \mathrm{mmol})$ and DMSO (5 mL) were 
sequentially added under argon outside the glove box. Then the Schlenck tube was placed in an oil bath pre-heated at $60{ }^{\circ} \mathrm{C}$. To the mixture was added $\mathrm{ZnEt}_{2}(1.5 \mathrm{M}$ in toluene, $1.0 \mathrm{~mL}, 1.5 \mathrm{mmol}$ ) with a syringe. After being vigorously stirred for $3 \mathrm{~h}$, the reaction was complete as monitored by TLC. $\mathrm{D}_{2} \mathrm{O}(1.0 \mathrm{~mL})$ was added to quench the reaction, and $3 \mathrm{M} \mathrm{HCl}(5 \mathrm{~mL})$ was added to dissolve the mixture. The aqueous layer was extracted with EtOAc $(5 \mathrm{~mL} \times 3)$ and the combined organic layer was washed with brine $(10 \mathrm{~mL})$, dried over anhydrous $\mathrm{MgSO}_{4}$, filtered and concentrated in vacuo to afford $(E, E)$-D-12a $(85.0 \mathrm{mg}$, purity of $94 \%, 67 \%)$ with a D-incorporation of $90 \%$ as determined by ${ }^{1} \mathrm{H}$ NMR analysis via column chromatography on silica gel (eluent: petroleum ether/ethyl acetate $=10 / 1)$ as an oil: ${ }^{1} \mathrm{H}$ NMR $\left(400 \mathrm{MHz}, \mathrm{CDCl}_{3}\right) \delta 5.77(\mathrm{q}$, $J=6.8 \mathrm{~Hz}, 1.10 \mathrm{H}, \mathrm{CH}=), 3.74\left(\mathrm{~s}, 6 \mathrm{H}, \mathrm{OCH}_{3} \times 2\right), 2.97\left(\mathrm{~s}, 4 \mathrm{H}, \mathrm{CH}_{2} \times 2\right), 1.73-1.67$ $\left(\mathrm{m}, 6 \mathrm{H}, \mathrm{CH}_{3} \times 2\right) ;{ }^{13} \mathrm{C} \mathrm{NMR}\left(100 \mathrm{MHz}, \mathrm{CDCl}_{3}\right) \delta 172.0,137.3,137.2,113.5,113.2(\mathrm{t}$, $\left.J_{C-D}=26.6 \mathrm{~Hz}\right), 57.4,52.7,37.57,37.54,14.6,14.5 ; \mathrm{MS}(\mathrm{EI})(\mathrm{m} / \mathrm{z}) 239\left([\mathrm{M}]^{+}\right.$ $\left.\left(\mathrm{C}_{13} \mathrm{H}_{17} \mathrm{DO}_{4}\right), 27.58\right), 238\left([\mathrm{M}]^{+}\left(\mathrm{C}_{13} \mathrm{H}_{18} \mathrm{O}_{4}\right), 6.81\right), 120$ (100); IR (neat, $\left.\mathrm{cm}^{-1}\right)$ 2955, 1733, 1434, 1260, 1231, 1200, 1161, 1116, 1091, 1060; HRMS calcd for $\mathrm{C}_{13} \mathrm{H}_{17} \mathrm{DO}_{4}$ $\left([\mathrm{M}]^{+}\right): 239.1268$; found: 239.1269 .

(6) Reaction of the in situ generated vinylic zinc intermediate with $\mathrm{CO}_{2}$. (ct-7-82)

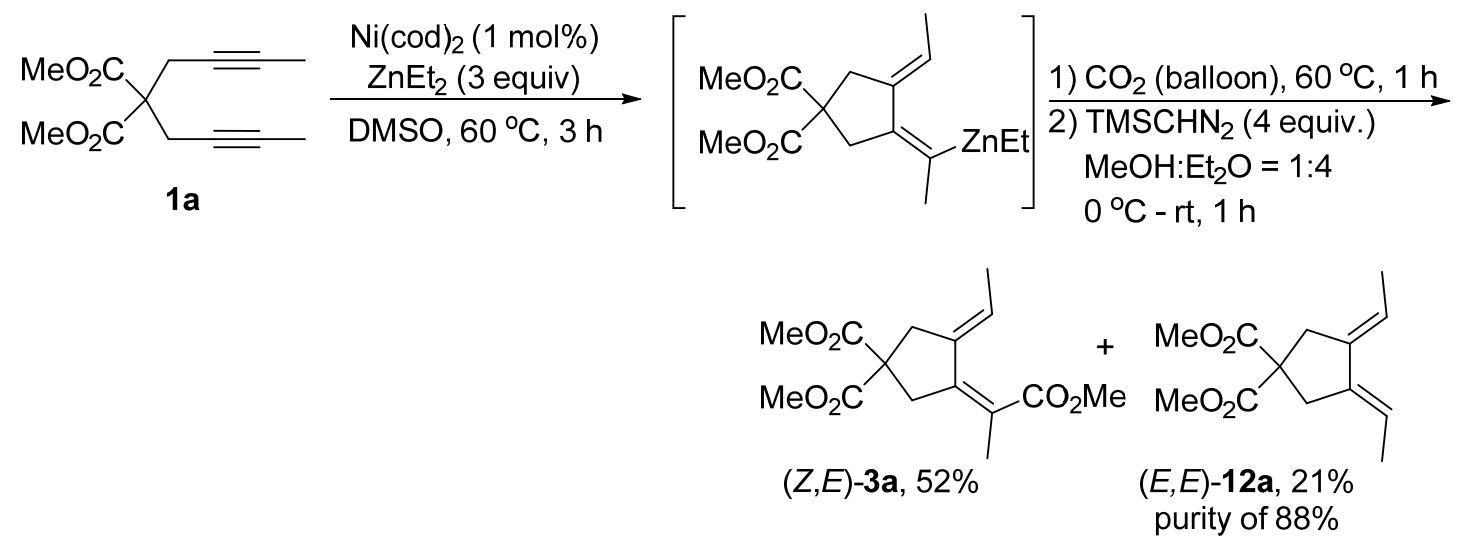

To a $25 \mathrm{~mL}$ flame-dried Schlenk tube was added $\mathrm{Ni}(\mathrm{cod})_{2}(1.4 \mathrm{mg}, 0.005 \mathrm{mmol})$ inside a glove box. Compound 1a (118.5 mg, $0.50 \mathrm{mmol})$ and DMSO (5 mL) were sequentially added under argon outside the glove box. Then the Schlenck tube was placed in an oil bath pre-heated at $60{ }^{\circ} \mathrm{C}$. To the mixture was added $\mathrm{ZnEt}_{2}(1.5 \mathrm{M}$ in toluene, $1.0 \mathrm{~mL}, 1.5 \mathrm{mmol}$ ) with a syringe. After being vigorously stirred for $3 \mathrm{~h}$, the 
Schlenk tube was frozen with a liquid nitrogen bath. The argon inside the tube was completely replaced with $\mathrm{CO}_{2}$ by using a balloon of $\mathrm{CO}_{2}$ (about $1 \mathrm{~L}$ ). The Schlenk tube was allowed to stand until the temperature was above $0{ }^{\circ} \mathrm{C}$. Then the Schlenk tube was placed in an oil bath pre-heated at $60{ }^{\circ} \mathrm{C}$. After being vigorously stirred for 1 $\mathrm{h}, 3 \mathrm{M} \mathrm{HCl}(5 \mathrm{~mL})$ was added to quench the reaction. The aqueous layer was extracted with EtOAc $(5 \mathrm{~mL} \times 3)$ and the combined organic layer was washed with brine $(10 \mathrm{~mL})$, dried over anhydrous $\mathrm{MgSO}_{4}$, filtered and concentrated in vacuo. To the crude product were added $\mathrm{MeOH}(1 \mathrm{~mL})$ and $\mathrm{Et}_{2} \mathrm{O}(4 \mathrm{~mL})$ and the flask containing the mixture was placed in an ice bath. To the resulting mixture was dropwise added $\mathrm{TMSCHN}_{2}(2.0 \mathrm{M}$ in hexane, $1.0 \mathrm{~mL}, 2.0 \mathrm{mmol})$ with a syringe. After being stirred for $1 \mathrm{~h}$ at room temperature, the reaction was complete as monitored by TLC. The reaction mixture was concentrated to afford $(Z, E)$-3a $(76.7$ $\mathrm{mg}, 52 \%)$ and $(E, E)-12 \mathrm{a}^{9}(29.0 \mathrm{mg}$, purity of $88 \%, 21 \%)$ via column chromatography on silica gel (eluent: petroleum ether/ethyl acetate $=10 / 1$ ).

(Z,E)-3a: more polar, oil; ${ }^{1} \mathrm{H}$ NMR $\left(400 \mathrm{MHz}, \mathrm{CDCl}_{3}\right) \delta 5.79(\mathrm{q}, J=6.7 \mathrm{~Hz}, 1 \mathrm{H}$, $\mathrm{CH}=), 3.74\left(\mathrm{~s}, 6 \mathrm{H}, \mathrm{OCH}_{3} \times 2\right), 3.72\left(\mathrm{~s}, 3 \mathrm{H}, \mathrm{OCH}_{3}\right), 3.03\left(\mathrm{~s}, 2 \mathrm{H}, \mathrm{CH}_{2}\right), 3.01(\mathrm{~s}, 2 \mathrm{H}$,

$\left.\mathrm{CH}_{2}\right), 1.91\left(\mathrm{~s}, 3 \mathrm{H}, \mathrm{CH}_{3}\right), 1.72\left(\mathrm{~d}, J=6.8 \mathrm{~Hz}, 3 \mathrm{H}, \mathrm{CH}_{3}\right) ;{ }^{13} \mathrm{C} \mathrm{NMR}\left(100 \mathrm{MHz}, \mathrm{CDCl}_{3}\right)$ $\delta 171.5,171.1,139.8,135.3,122.7,119.9,56.4,52.8,51.6,39.1,37.5,18.0,15.3$.

$(E, E)-12 a:{ }^{9}$ less polar, oil; ${ }^{1} \mathrm{H}$ NMR $\left(400 \mathrm{MHz}, \mathrm{CDCl}_{3}\right) \delta 5.77(\mathrm{q}, J=6.7 \mathrm{~Hz}, 2$ $\mathrm{H}, \mathrm{CH}=), 3.74\left(\mathrm{~s}, 6 \mathrm{H}, \mathrm{OCH}_{3} \times 2\right), 2.97\left(\mathrm{~s}, 4 \mathrm{H}, \mathrm{CH}_{2} \times 2\right), 1.69(\mathrm{~d}, J=6.8 \mathrm{~Hz}, 6 \mathrm{H}$, $\left.\mathrm{CH}_{3} \times 2\right) ;{ }^{13} \mathrm{C} \mathrm{NMR}\left(100 \mathrm{MHz}, \mathrm{CDCl}_{3}\right) \delta 172.1,137.4,113.5,57.5,52.7,37.6,14.6$.

\section{References}

(1) Amatore, M.; Lebœuf, D.; Malacria, M.; Gandon, V.; Aubert C. J. Am. Chem. Soc. 2013, 135, 4576.

(2) Wilking, M.; Mück-Lichtenfeld, C.; Daniliuc, C. G. Hennecke, U. J. Am. Chem. Soc. 2013, 135, 8133.

(3) Nishida, M.; Shiga, H.; Mori, M. J. Org. Chem. 1998, 63, 860.

(4) Louie, J.; Gibby, J. E.; Farnworth, M. V.; Tekavec T. N. J. Am. Chem. Soc. 2002, $124,15188$.

(5) Liu, C.; Widenhoefer, R. A. Organometallics 2002, 21, 5666. 
(6) Tekevac, T. N.; Louie, J. Org. Lett. 2005, 7, 4037.

(7) Atkinson, R. S.; Grimshire, M. J. J. Chem. Soc. Perkin Trans. 1 1986, 1215.

(8) Lawrence, R. M.; Perlmutter, P. Aust. J. Chem. 1996, 49, 839.

(9) Jang, H.-Y.; Krische, M. J. J. Am. Chem. Soc. 2004, 126, 7875. 

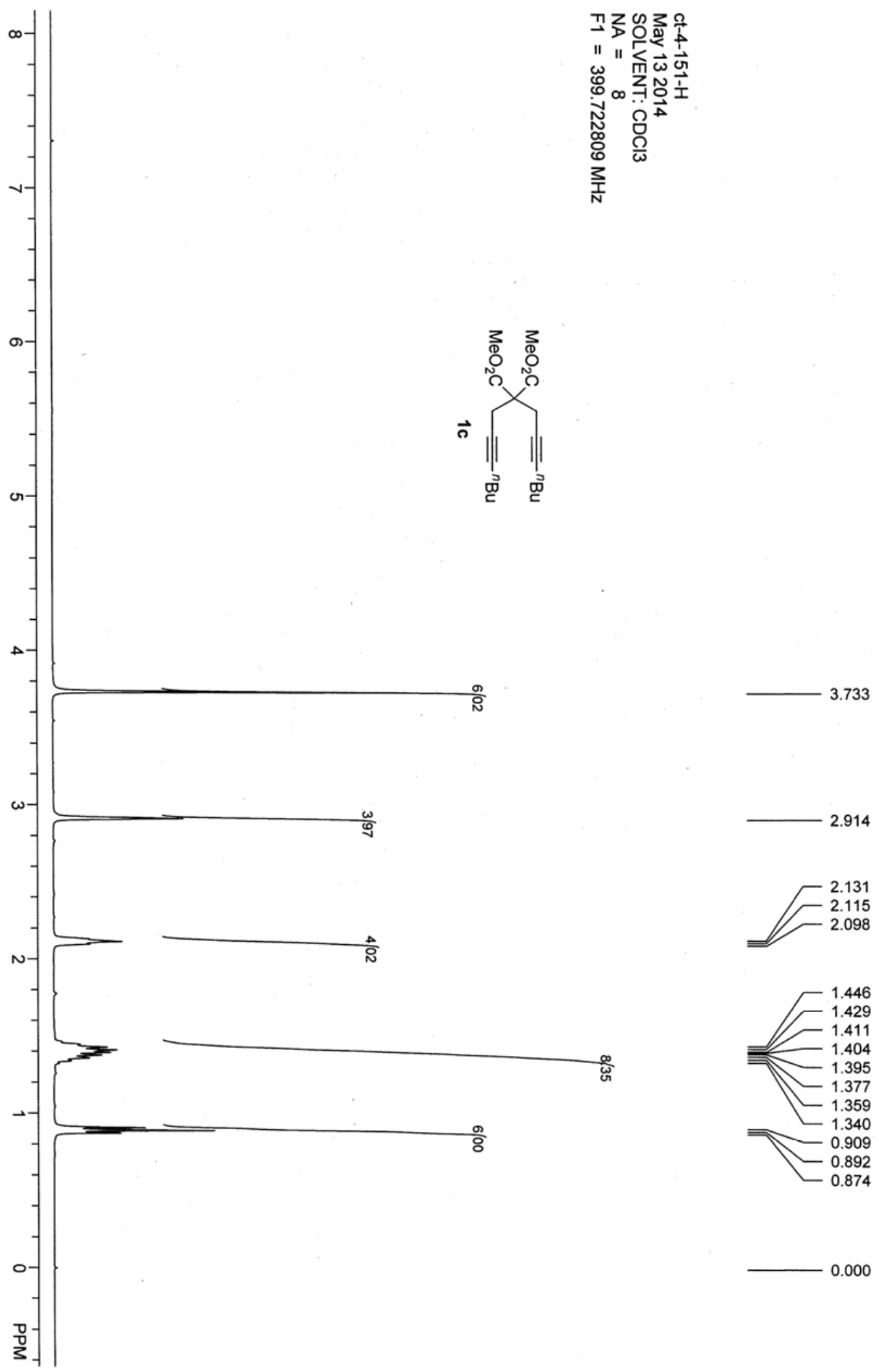

0.000 

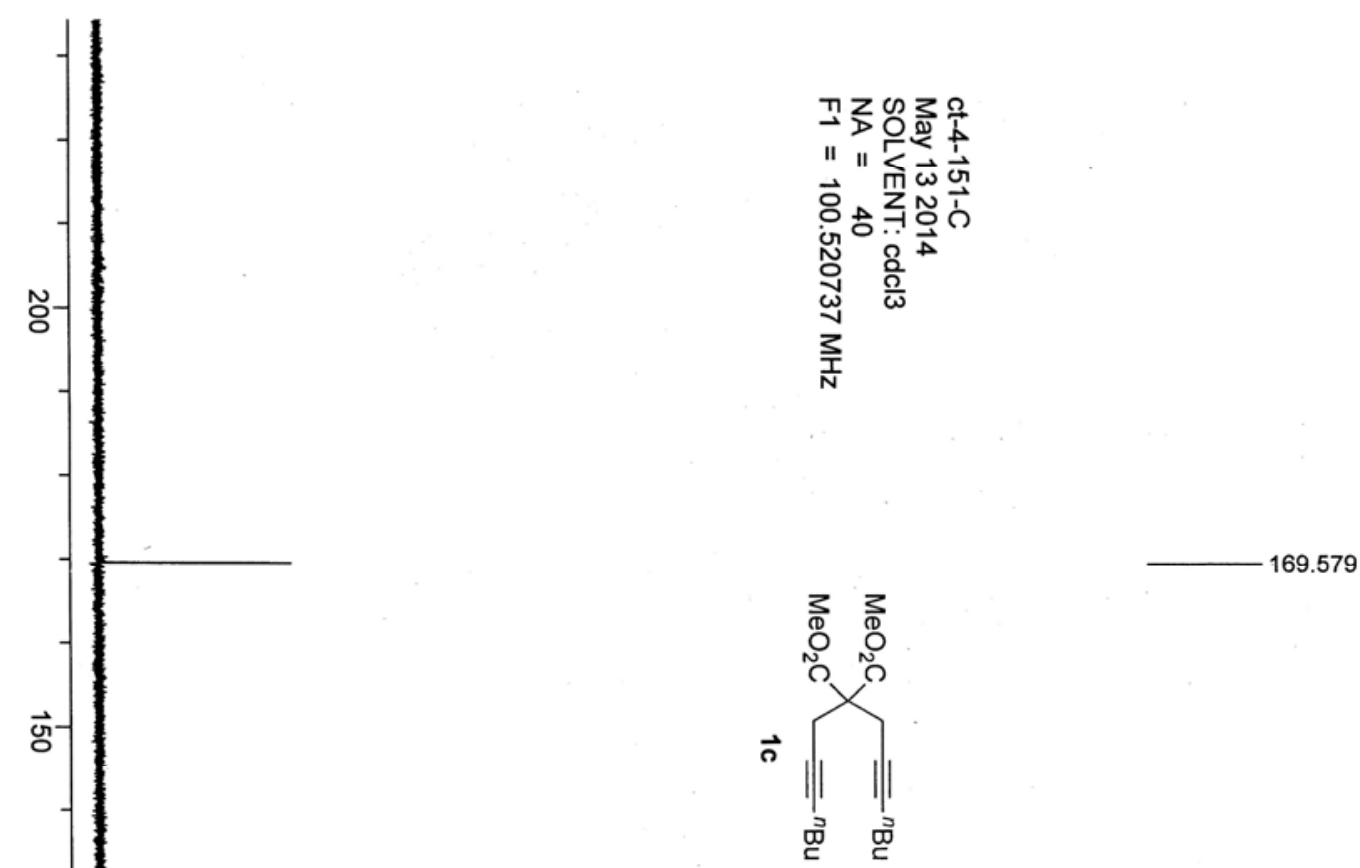

。
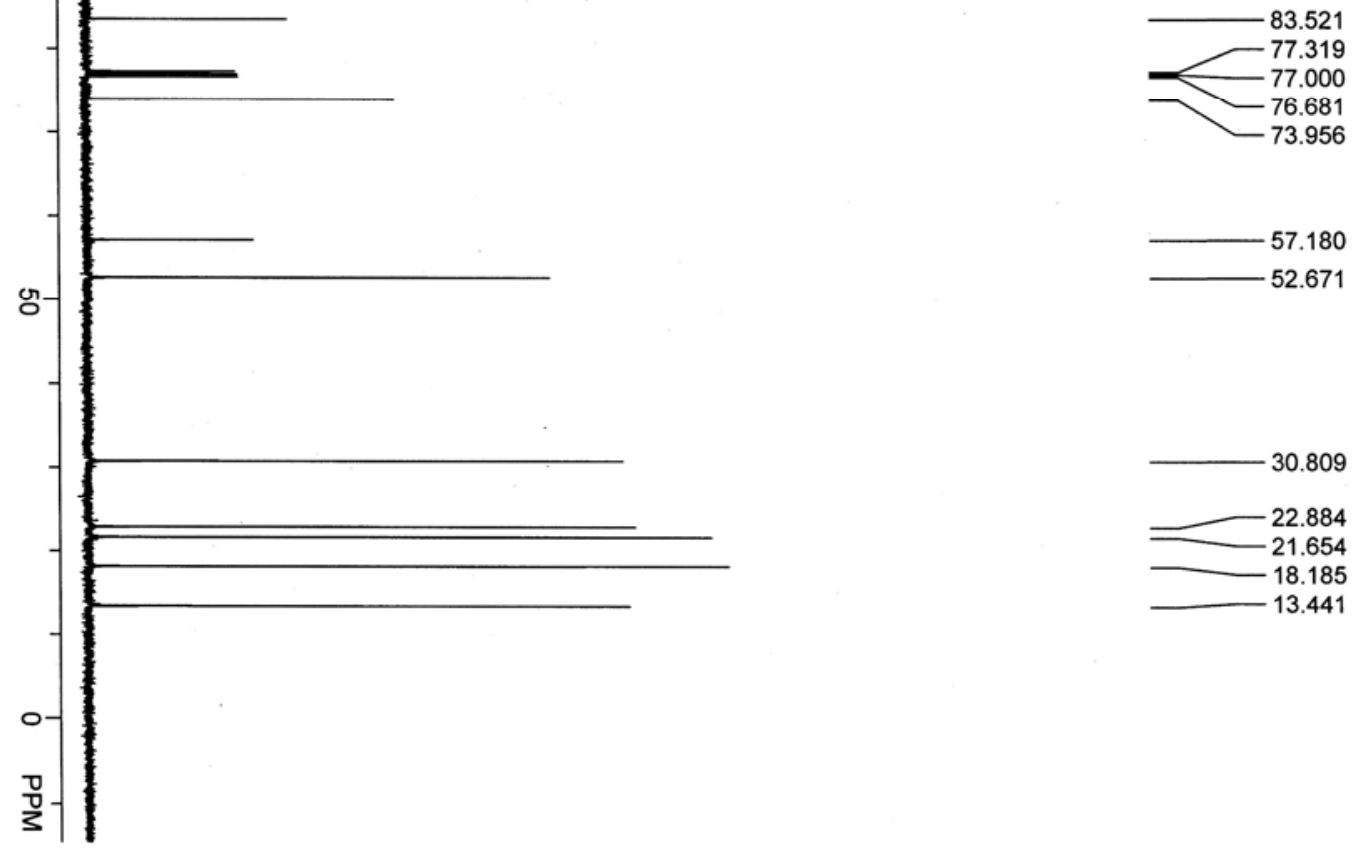

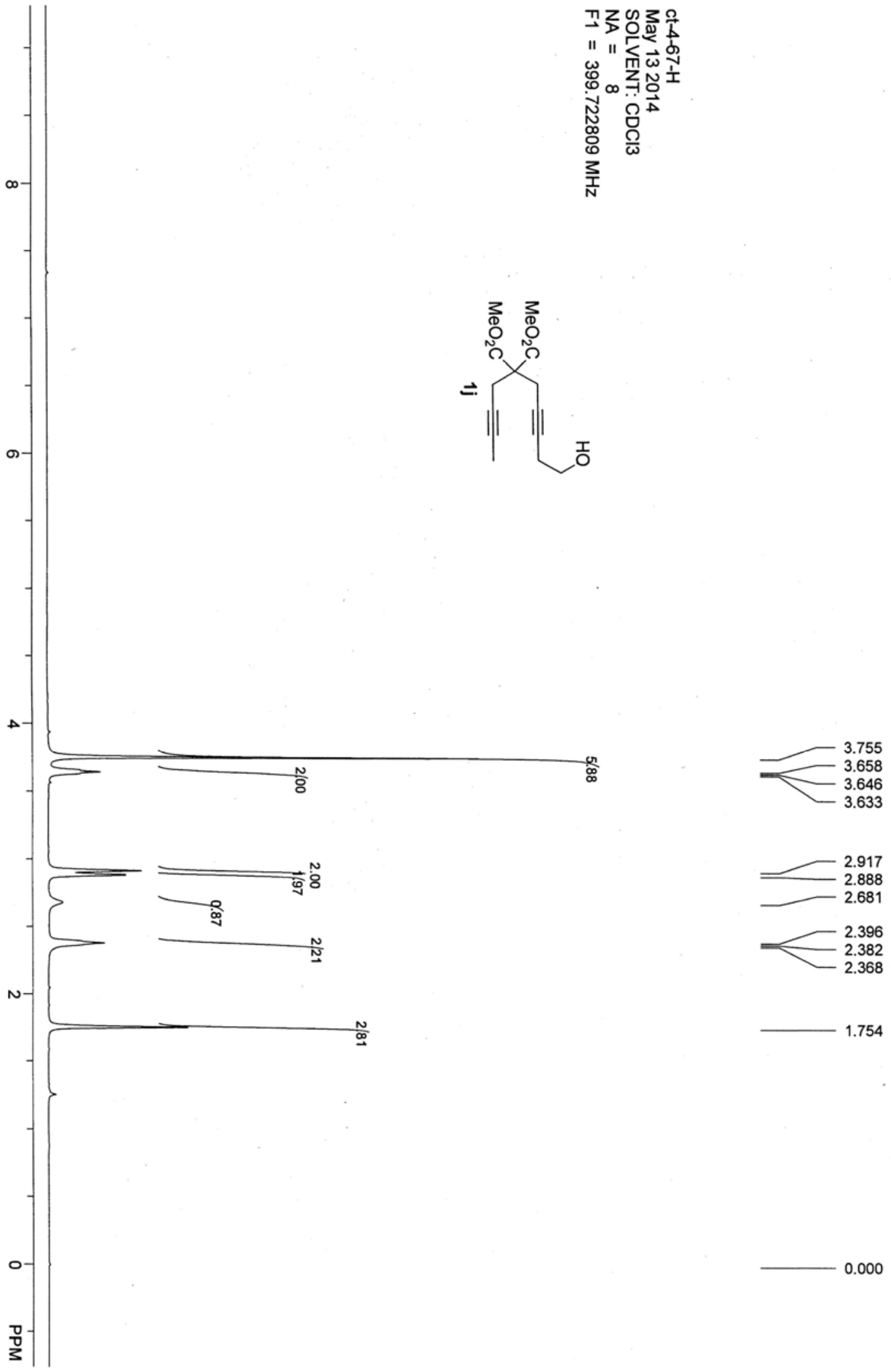

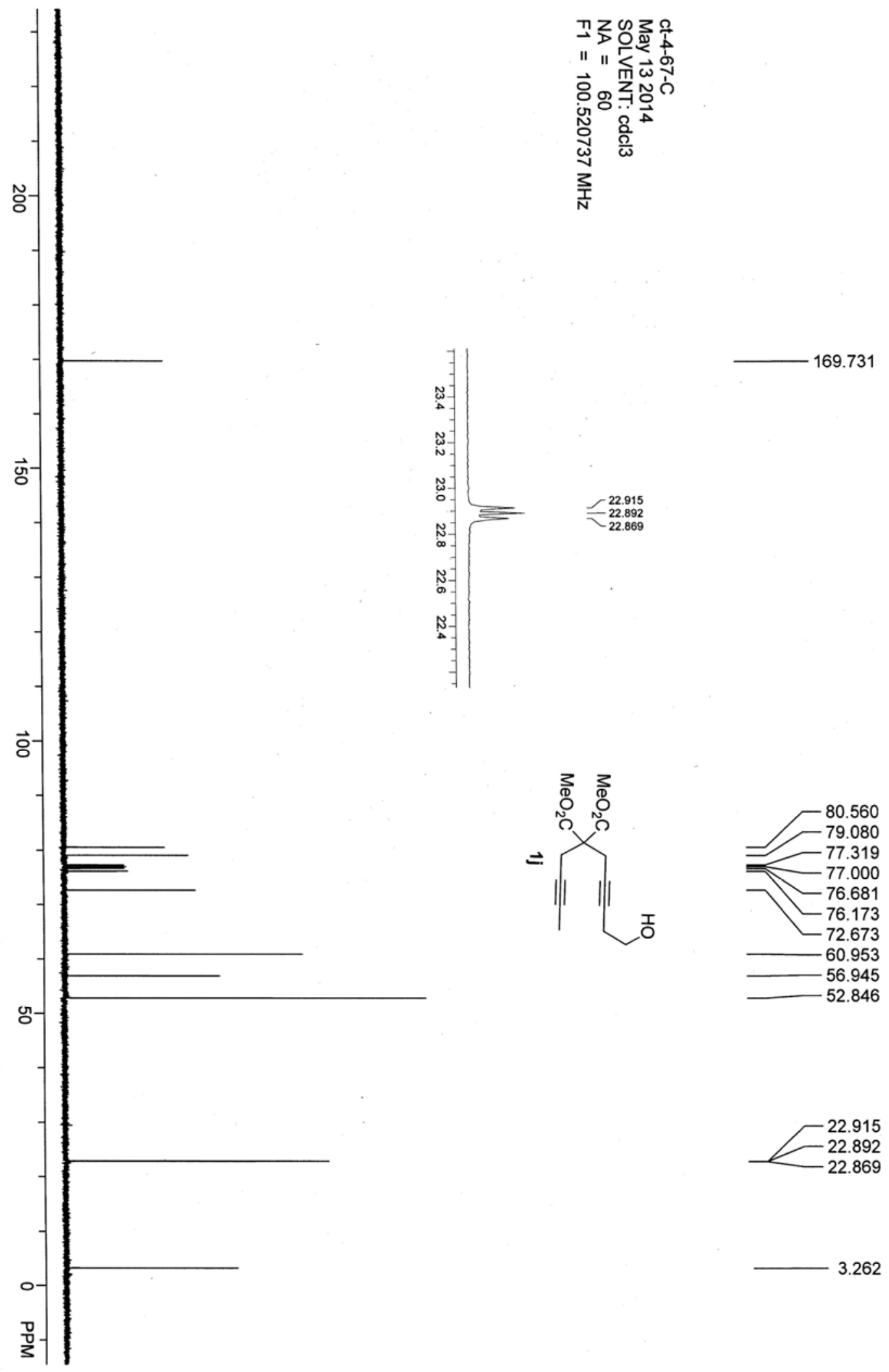

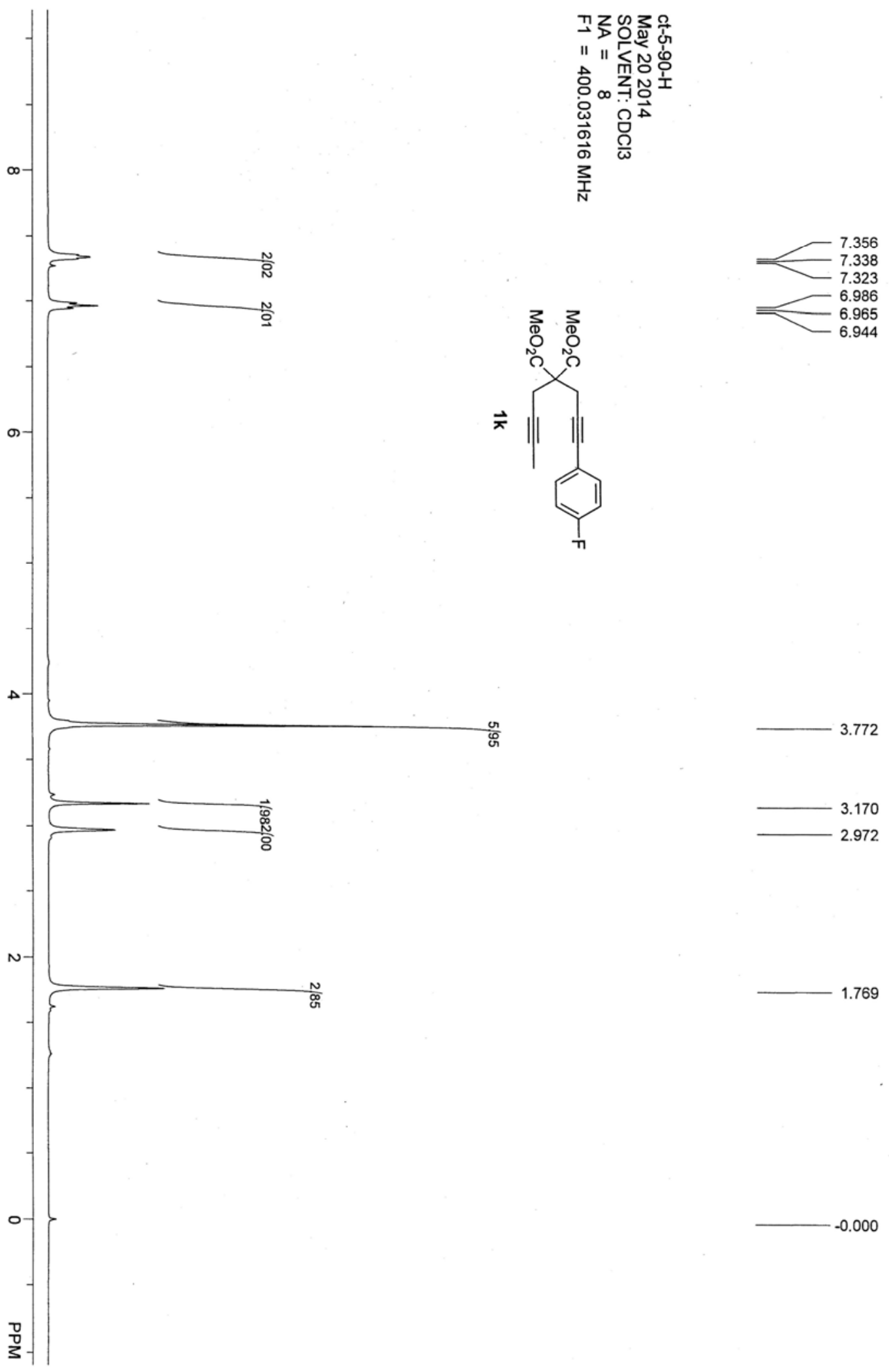

$-0.000$ 


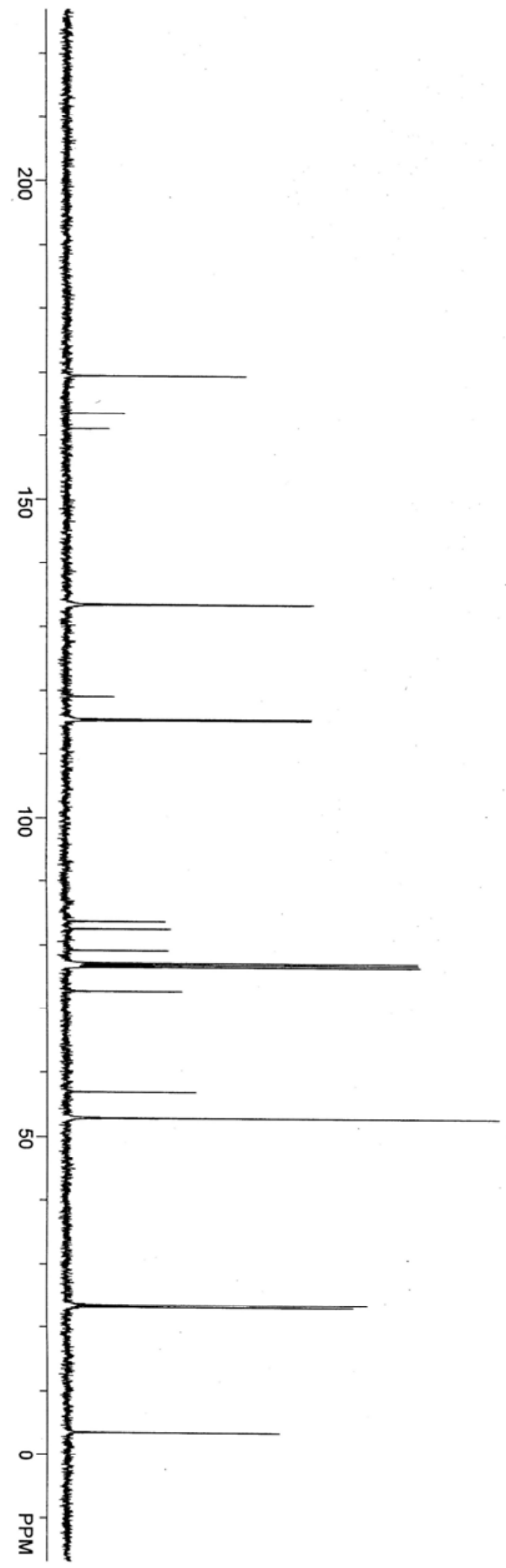

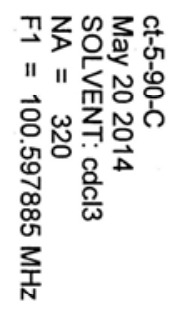
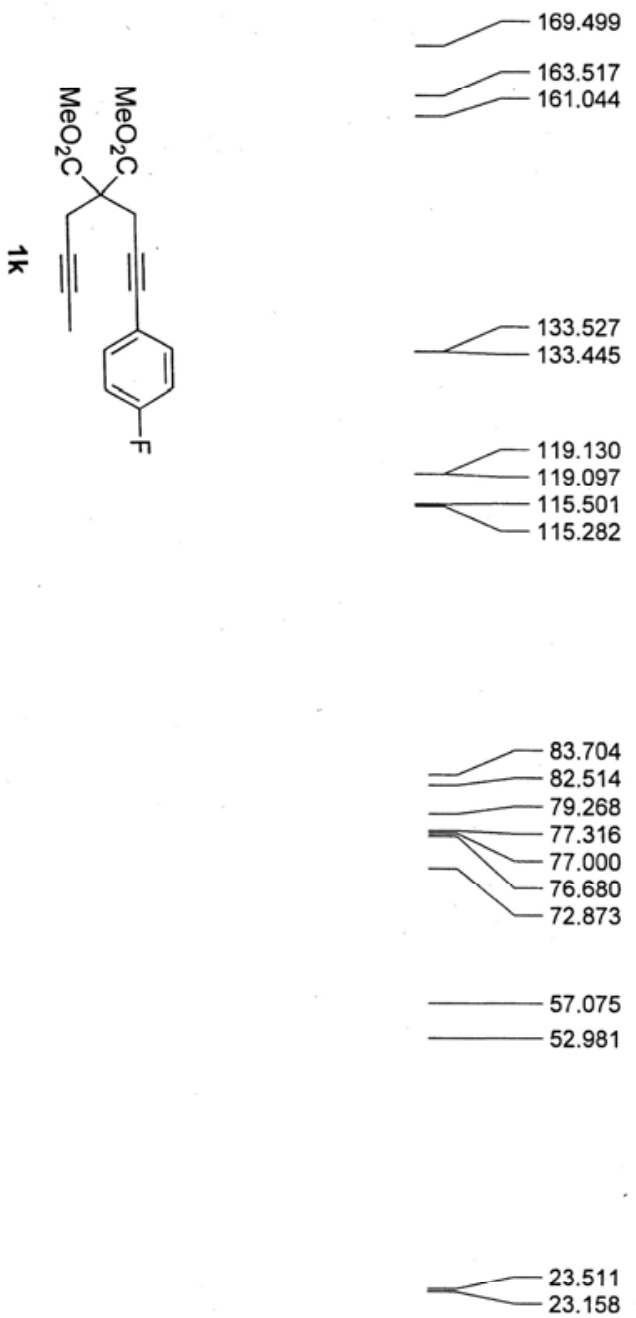

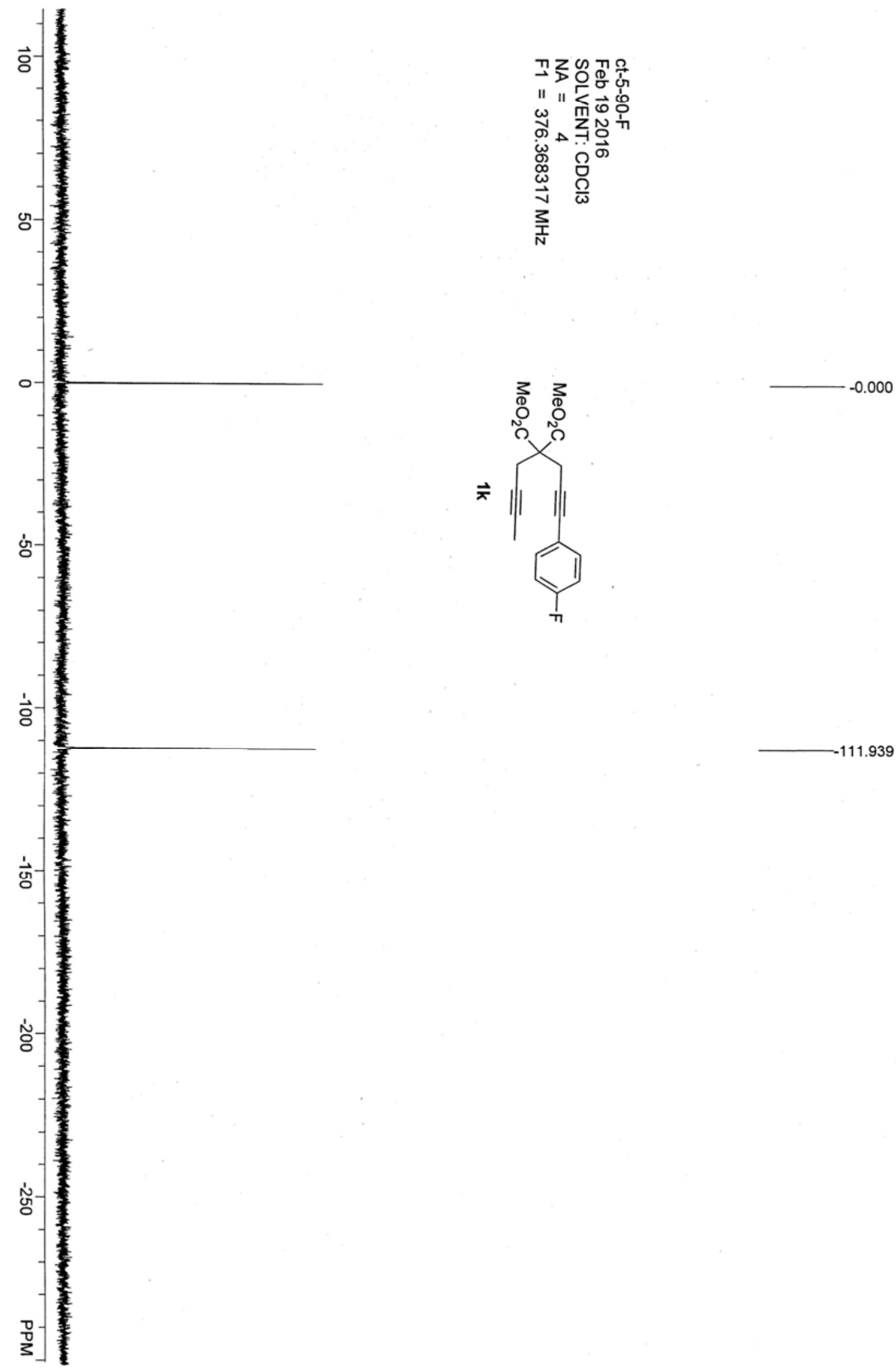


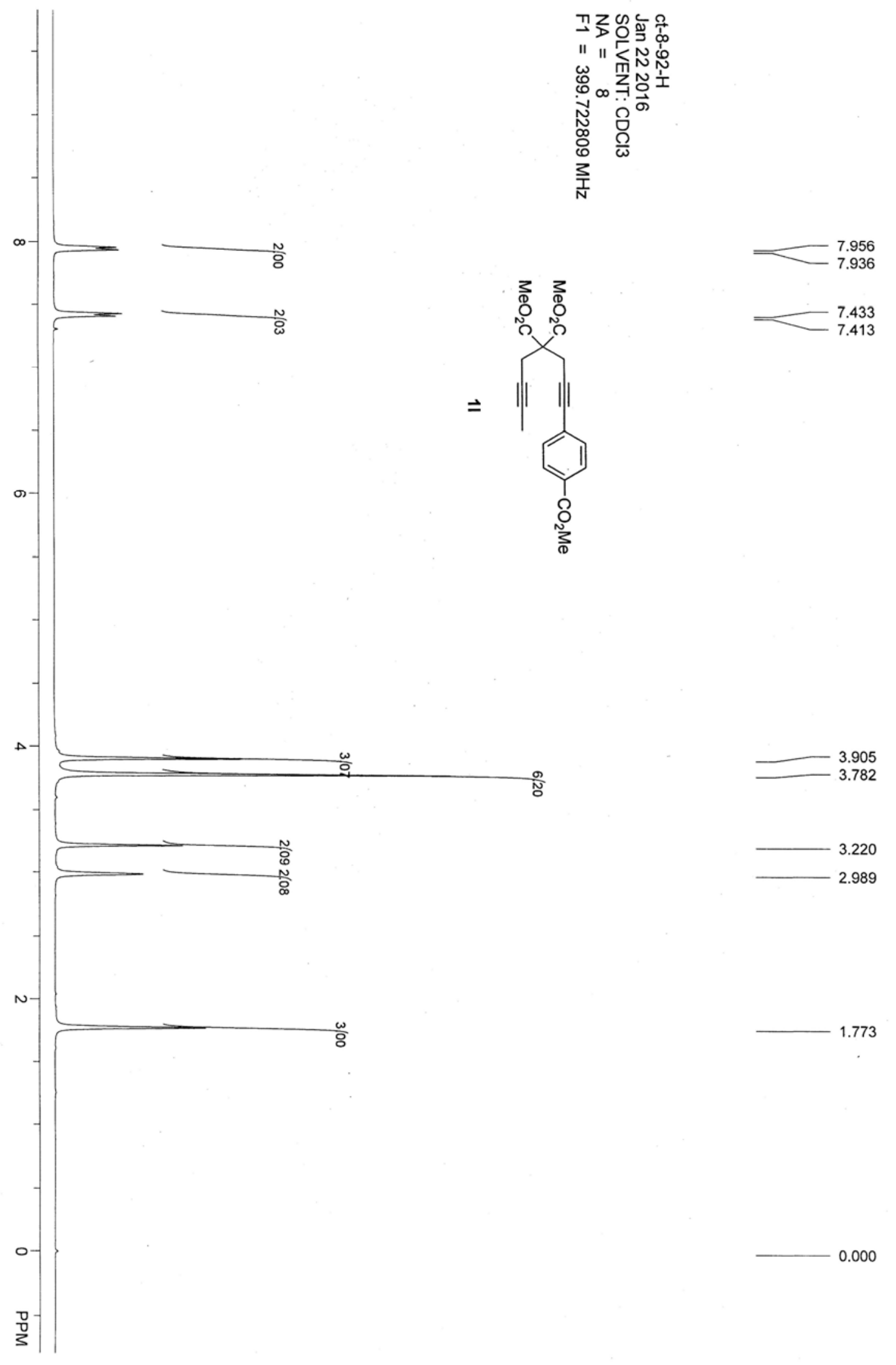




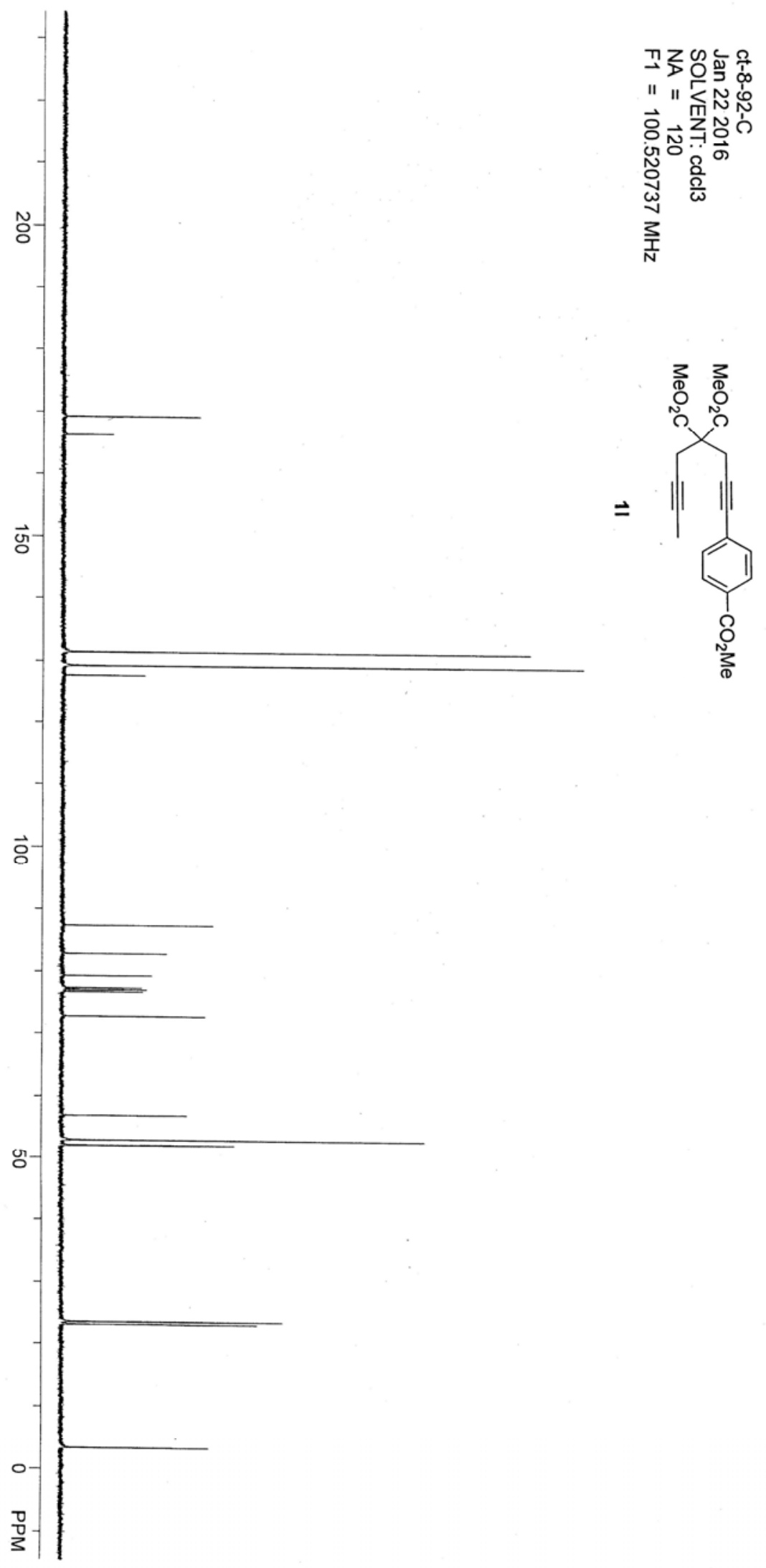

$$
\begin{aligned}
& \rightarrow>\text { 잉 } \\
& \text { " " } \\
& \text { 흐음응 } \\
& \text { స్ํํำ } \\
& \text { 采 }
\end{aligned}
$$
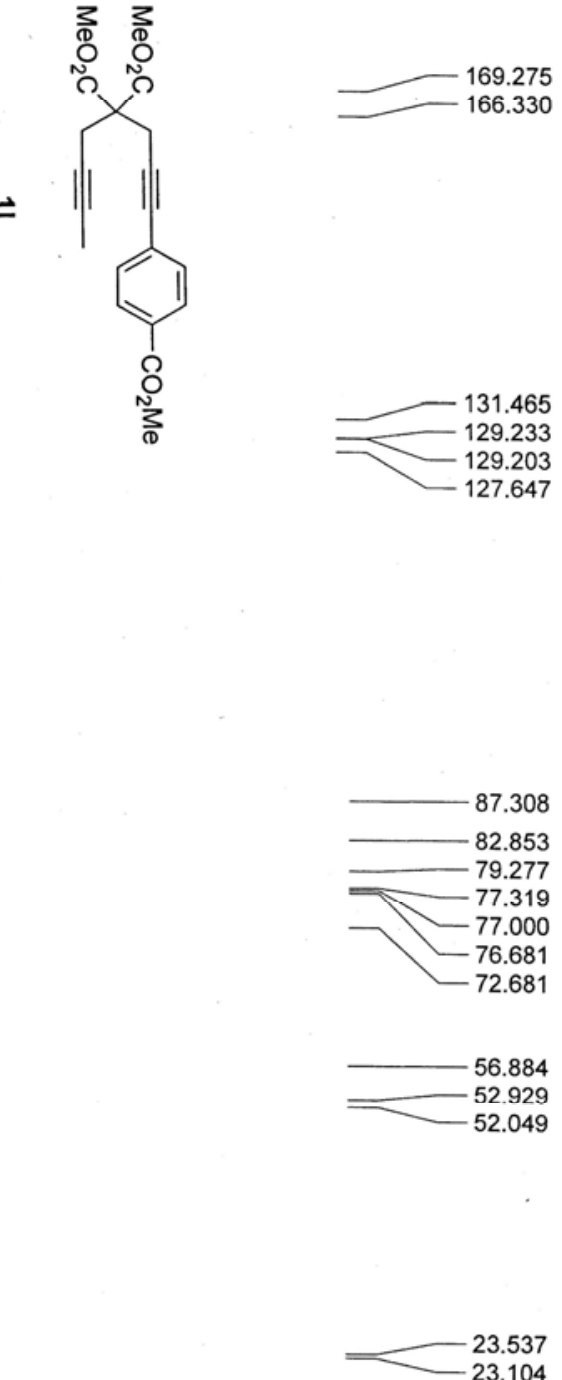

23.10 

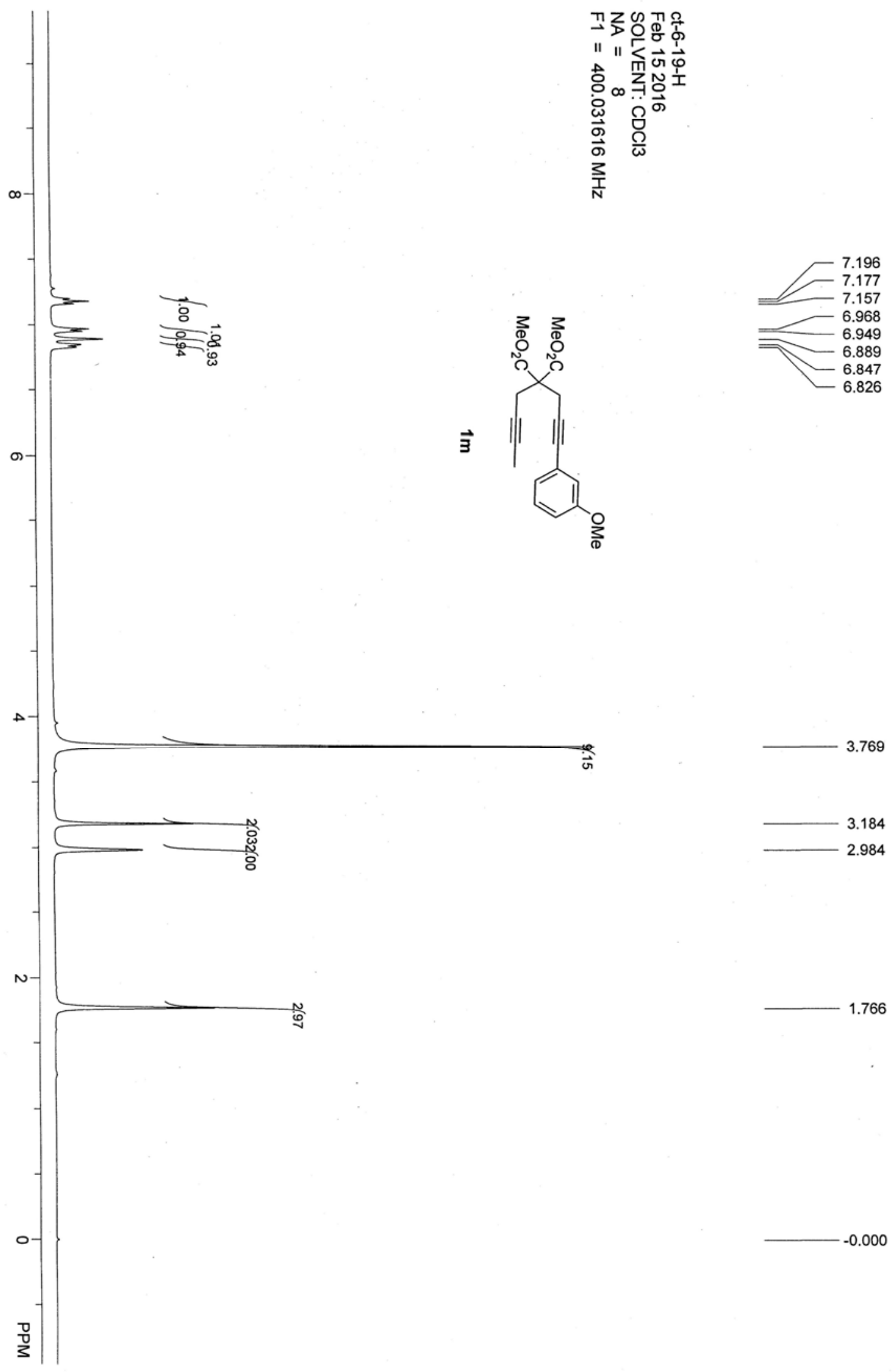

3.184 

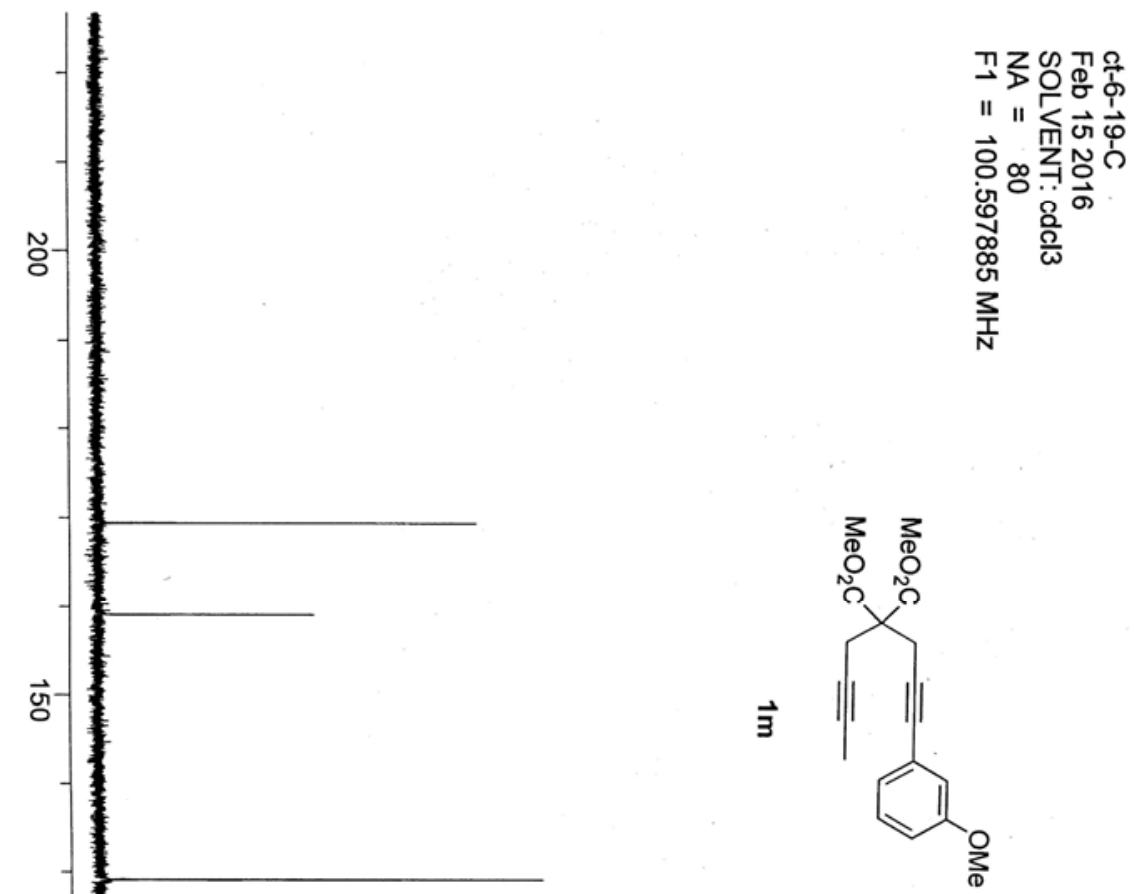

169.434

- 159.105

जु-

$\overrightarrow{\mathrm{o}}$

잉-

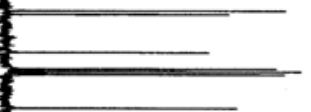

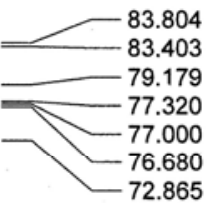

$-57.026$

55.115

$-52.921$

23.481

23.086

ㅁํㄹ 

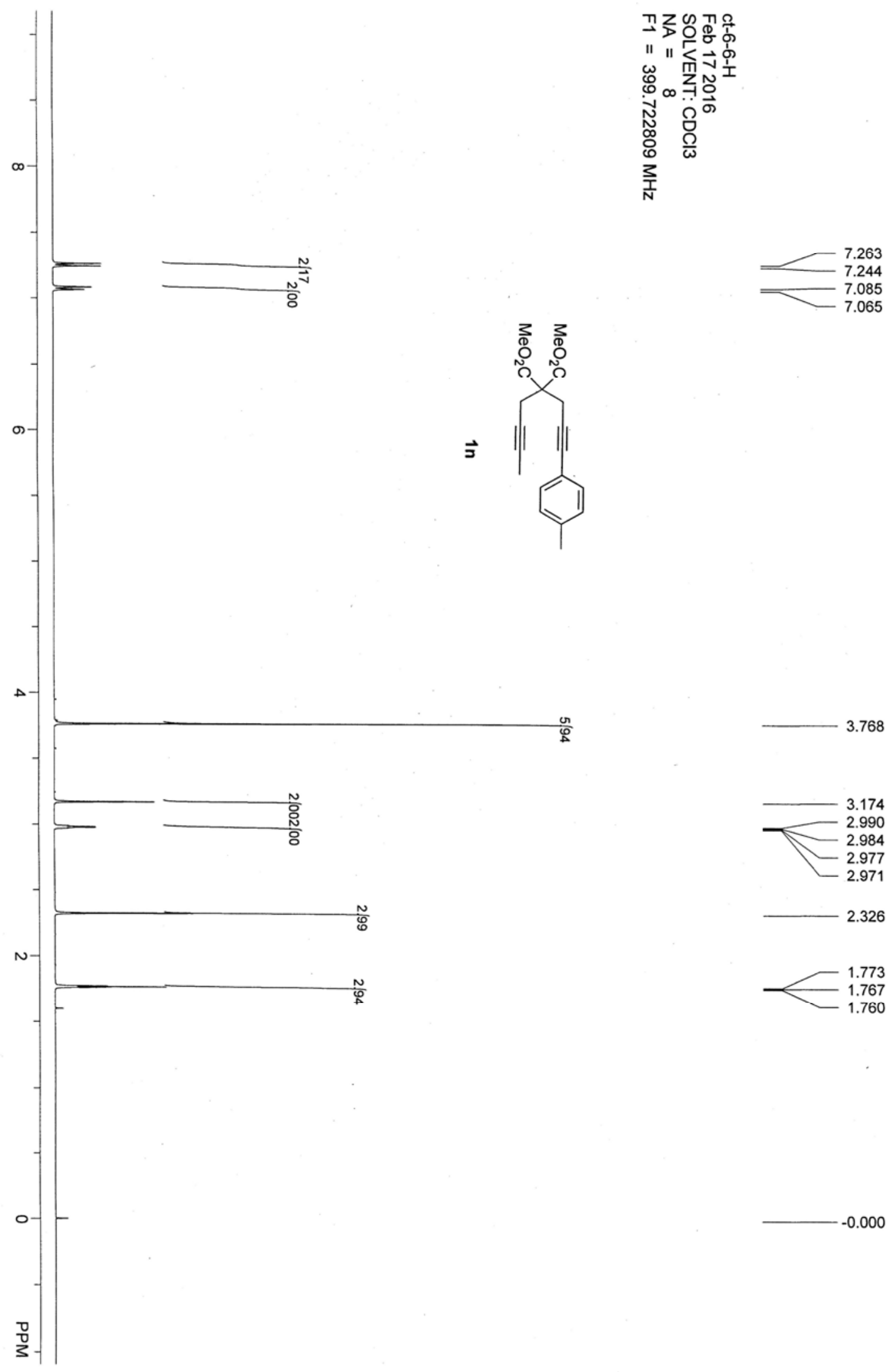

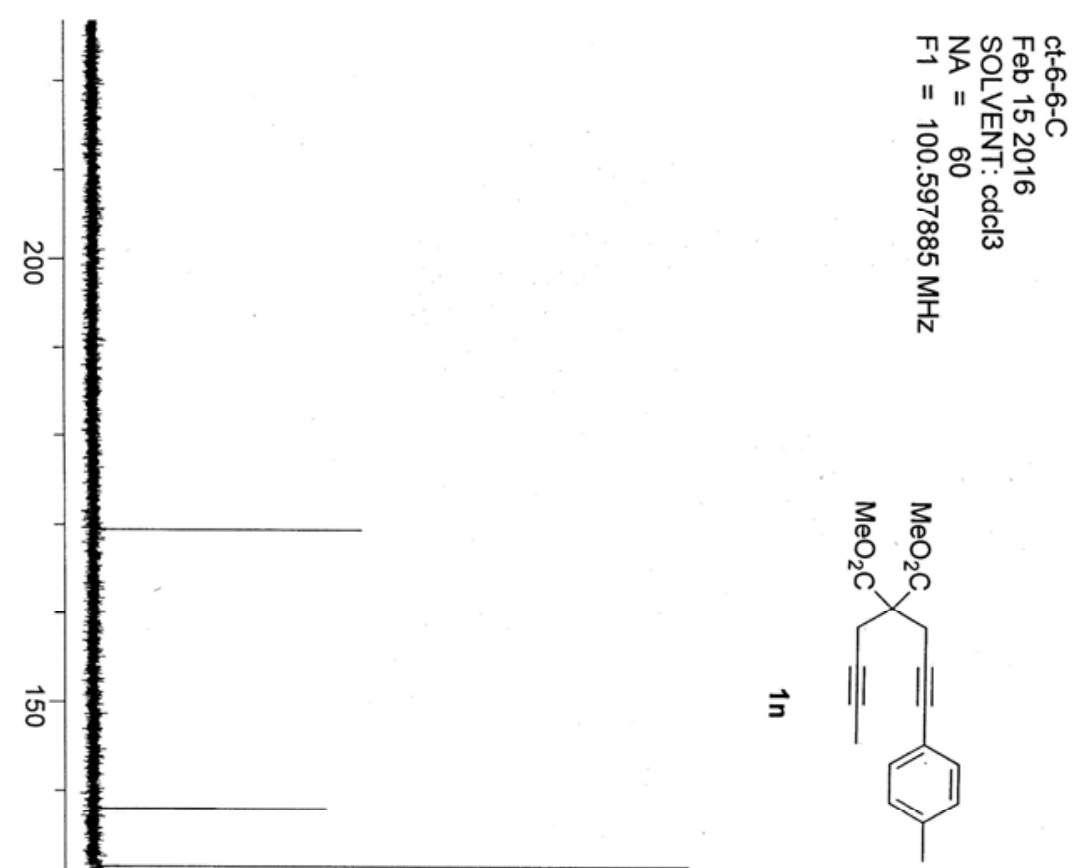

169.486
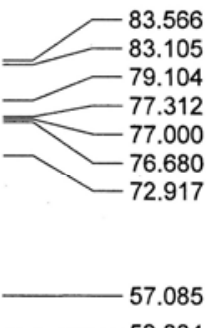

$-52.884$

23.503

$-23.057$

$-21.309$

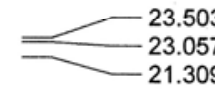

3.425 

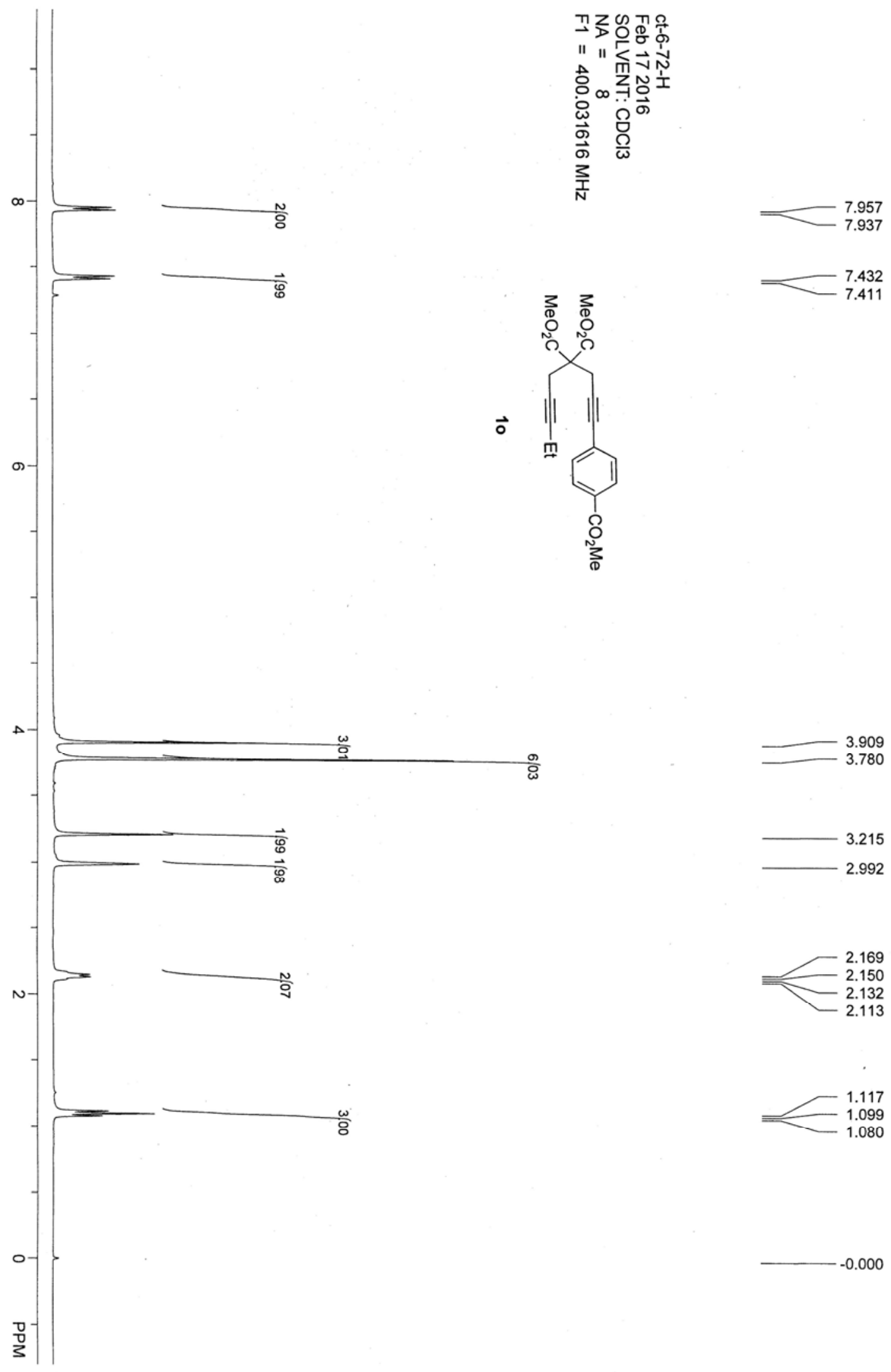

1.117 1.099
1.080 $-0.000$ 

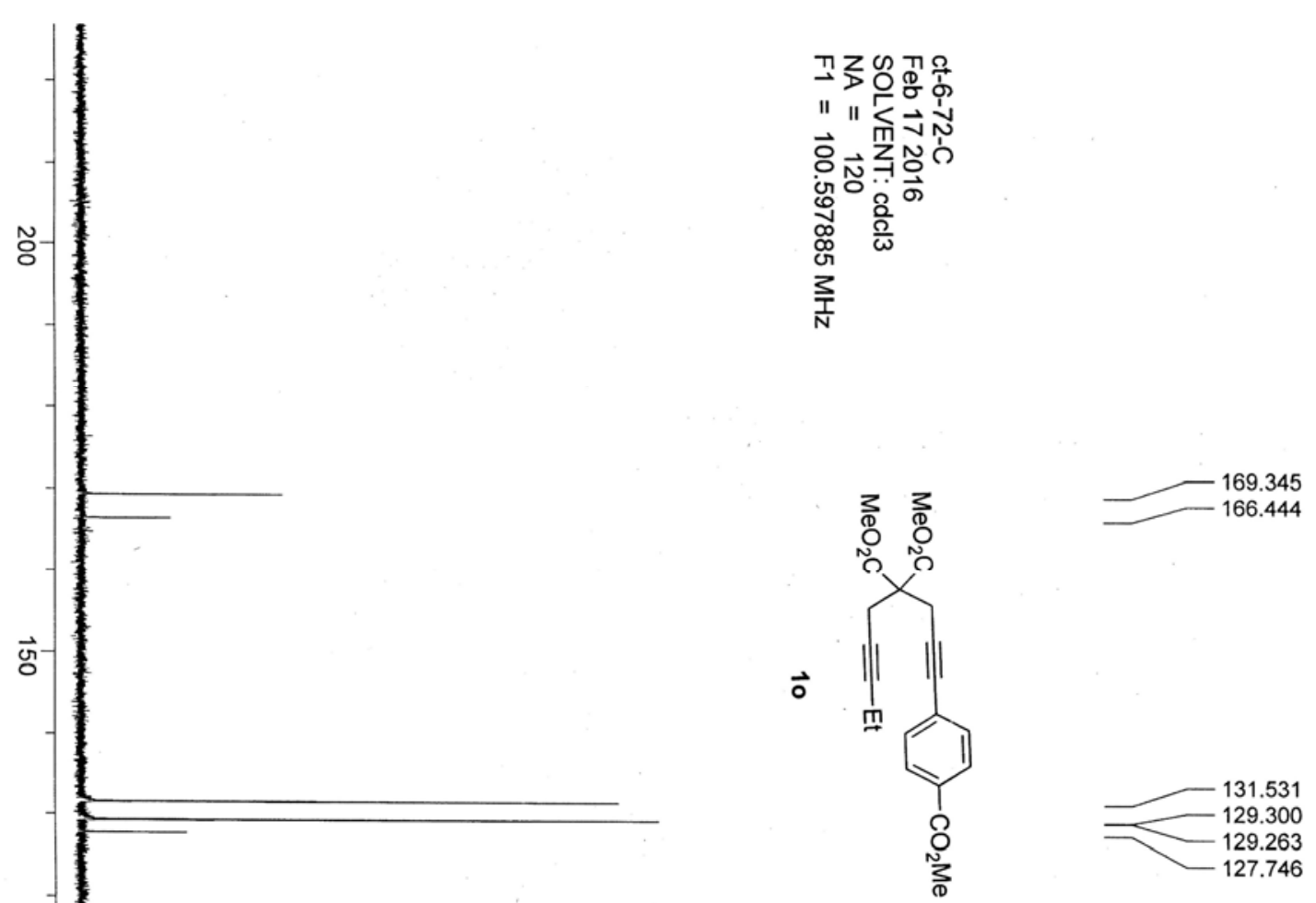

$\overrightarrow{8}$

등-

ज्ञ

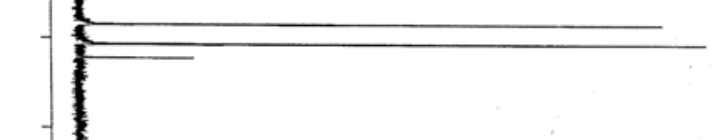

产

-
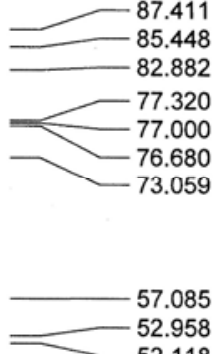

52.118

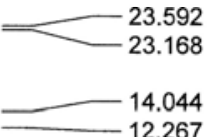

14.044
12.267 

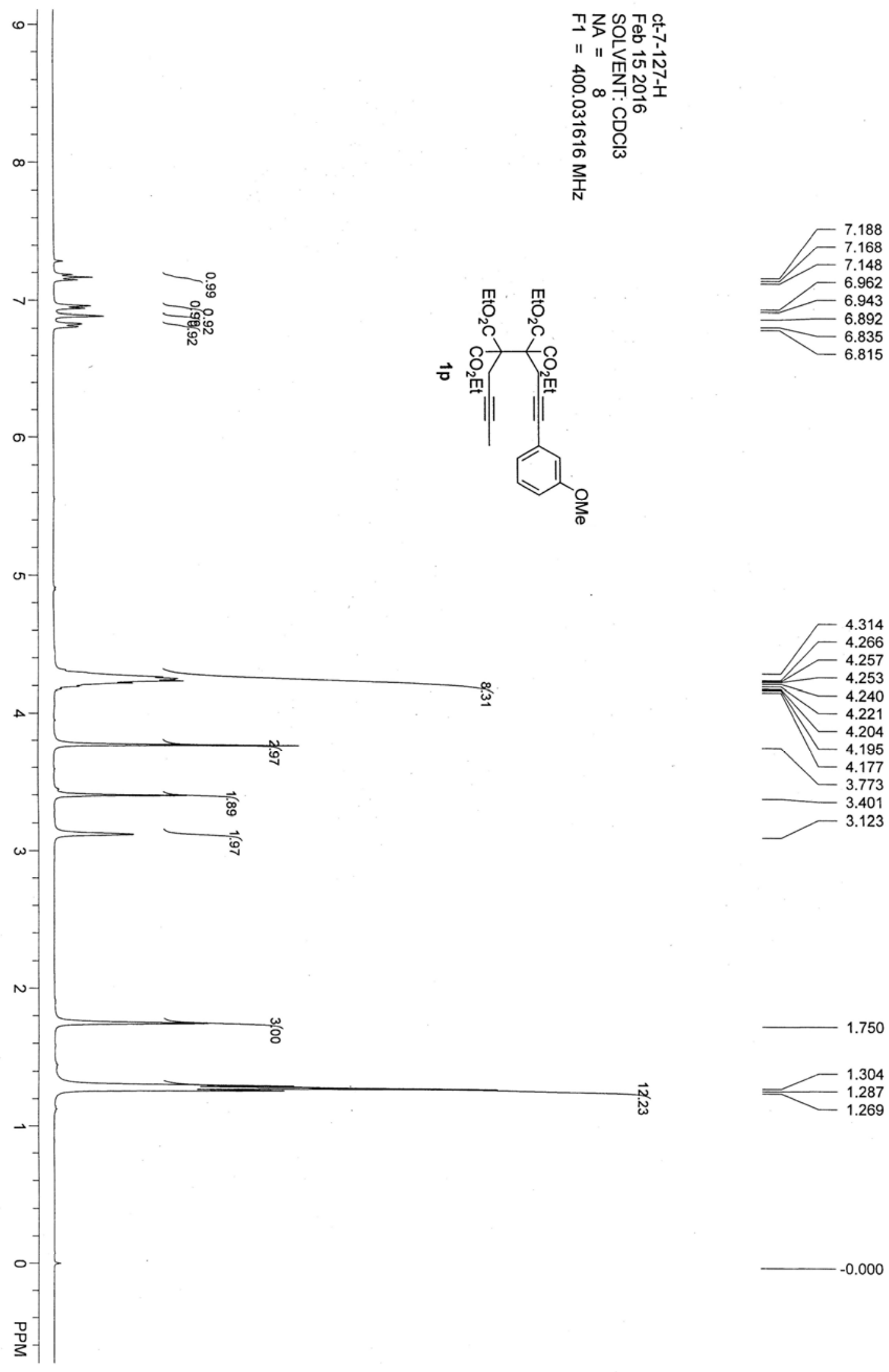

1.750

1.304

1.287

- 1.269

$-0.000$ 

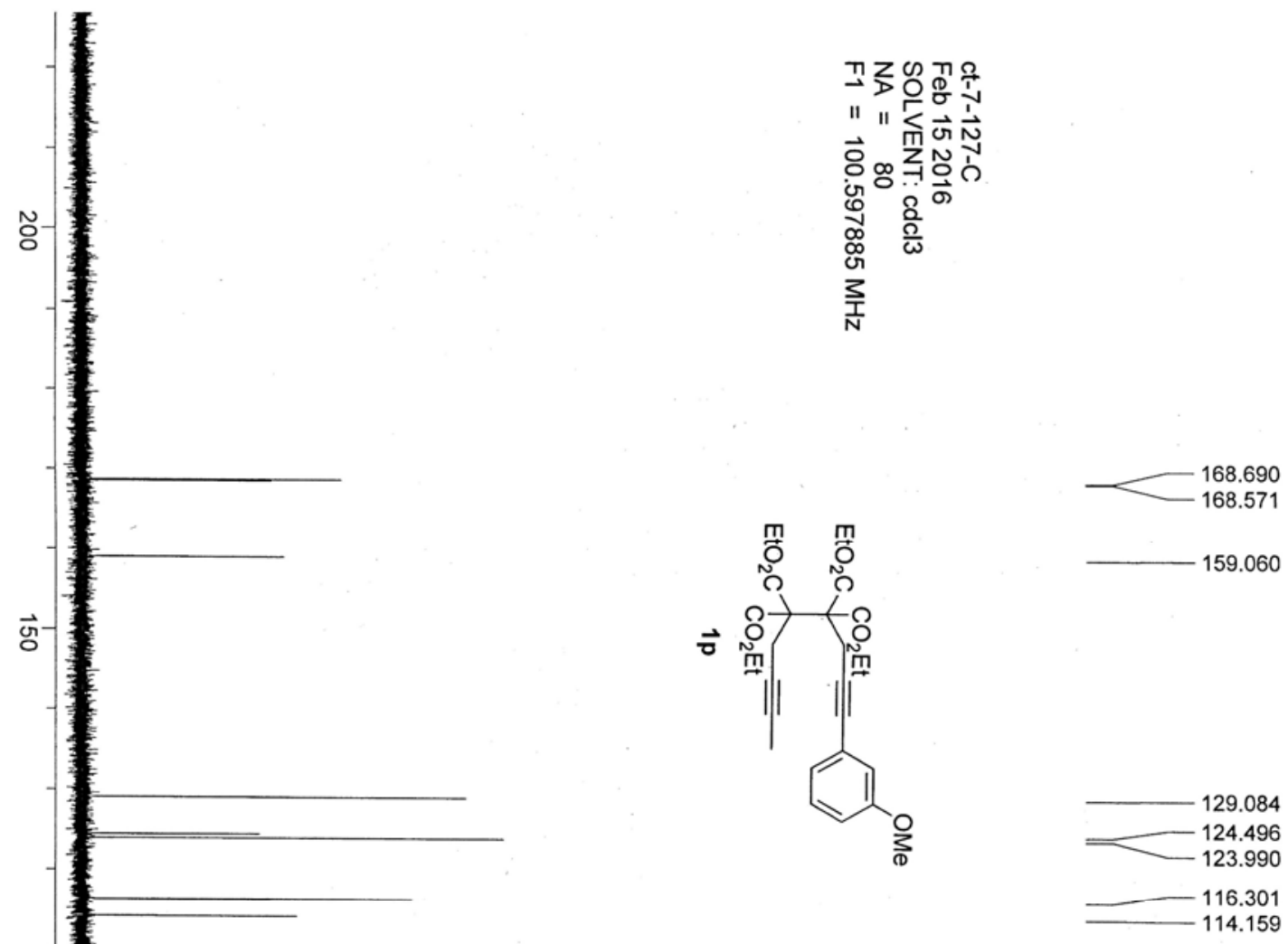

$\overrightarrow{8}$

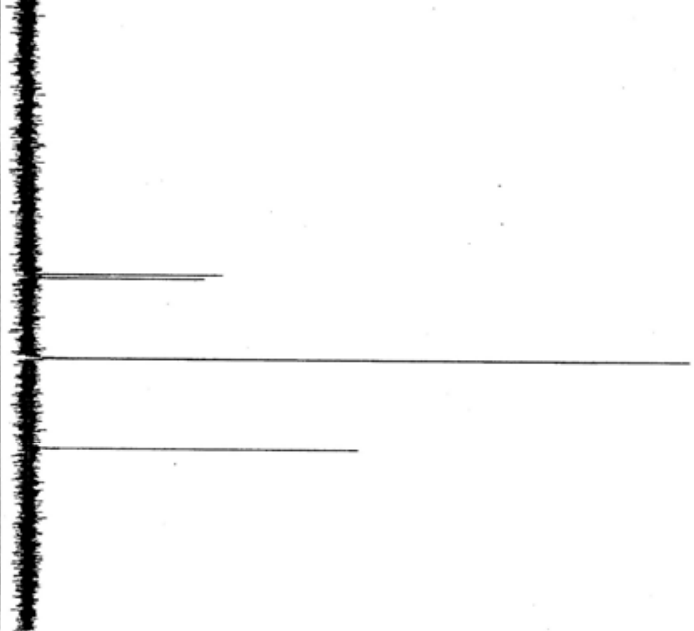

-23.198 22.774

13.776

- 13.739

3.566 

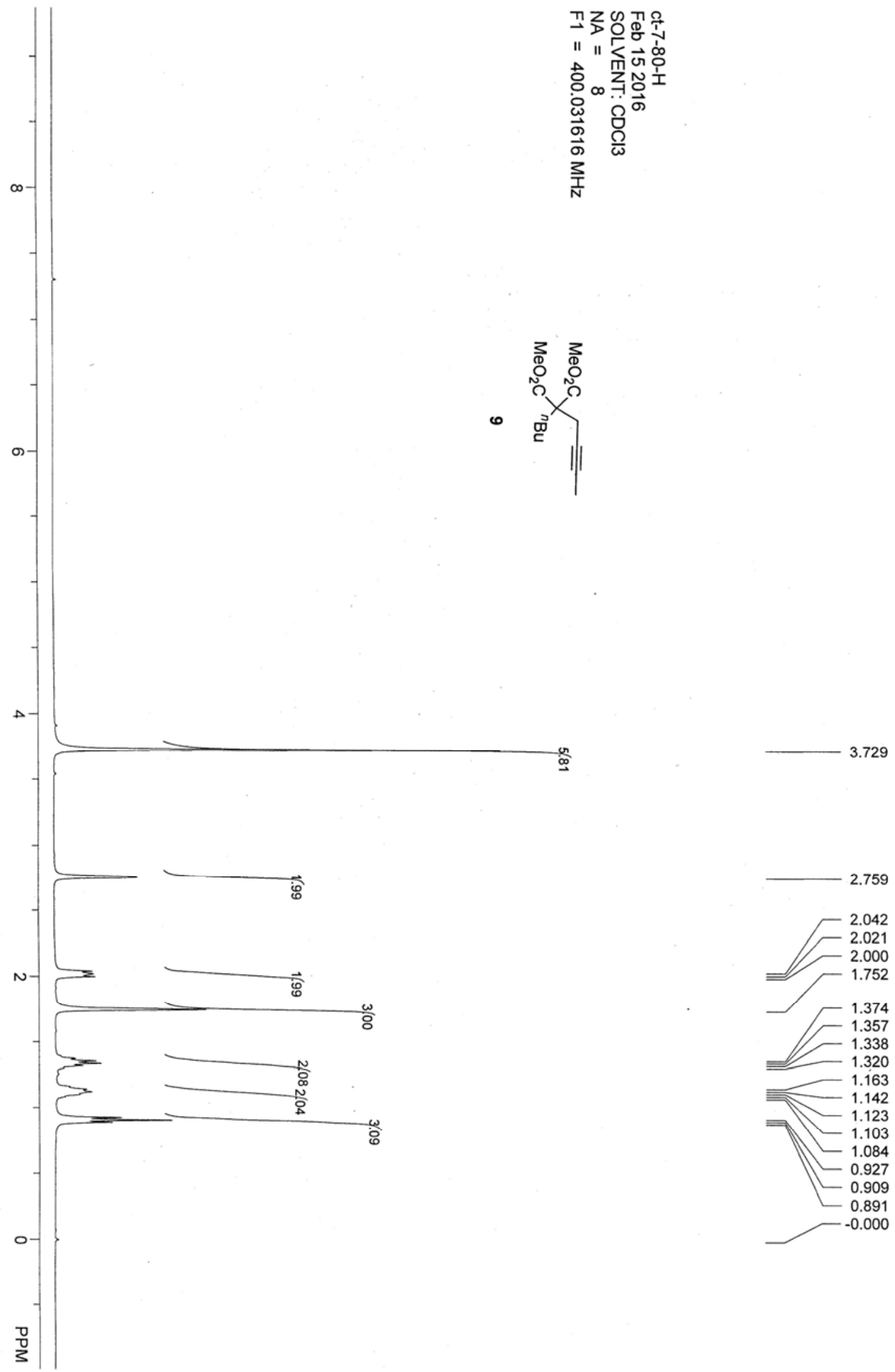


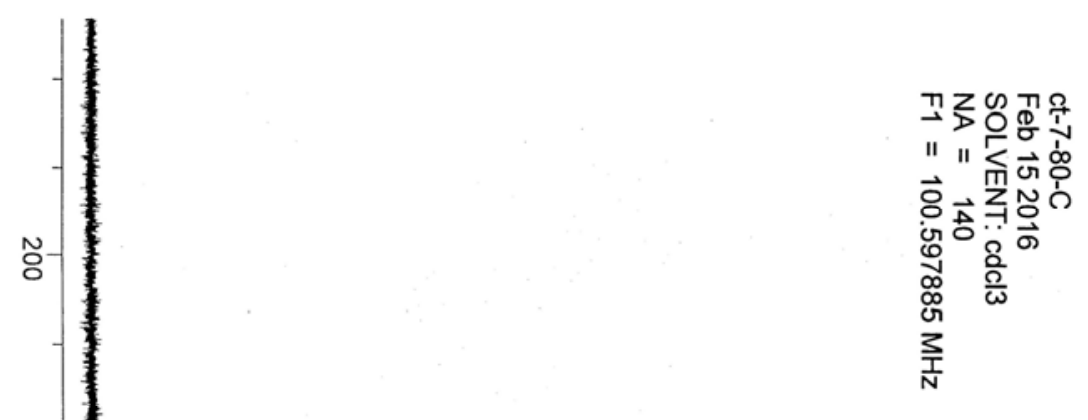

$\omega$

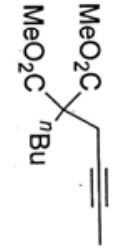
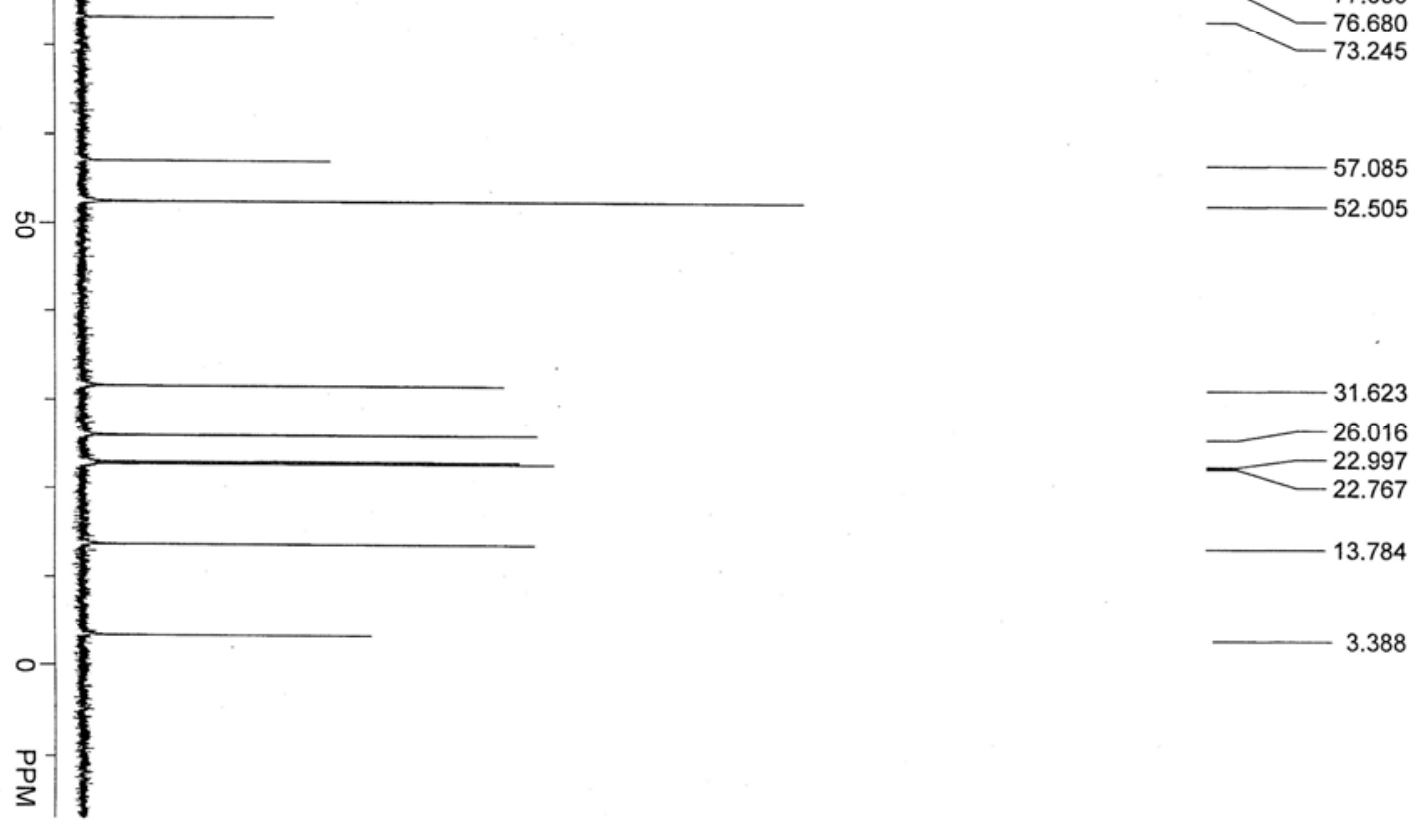

3.388

ग0 

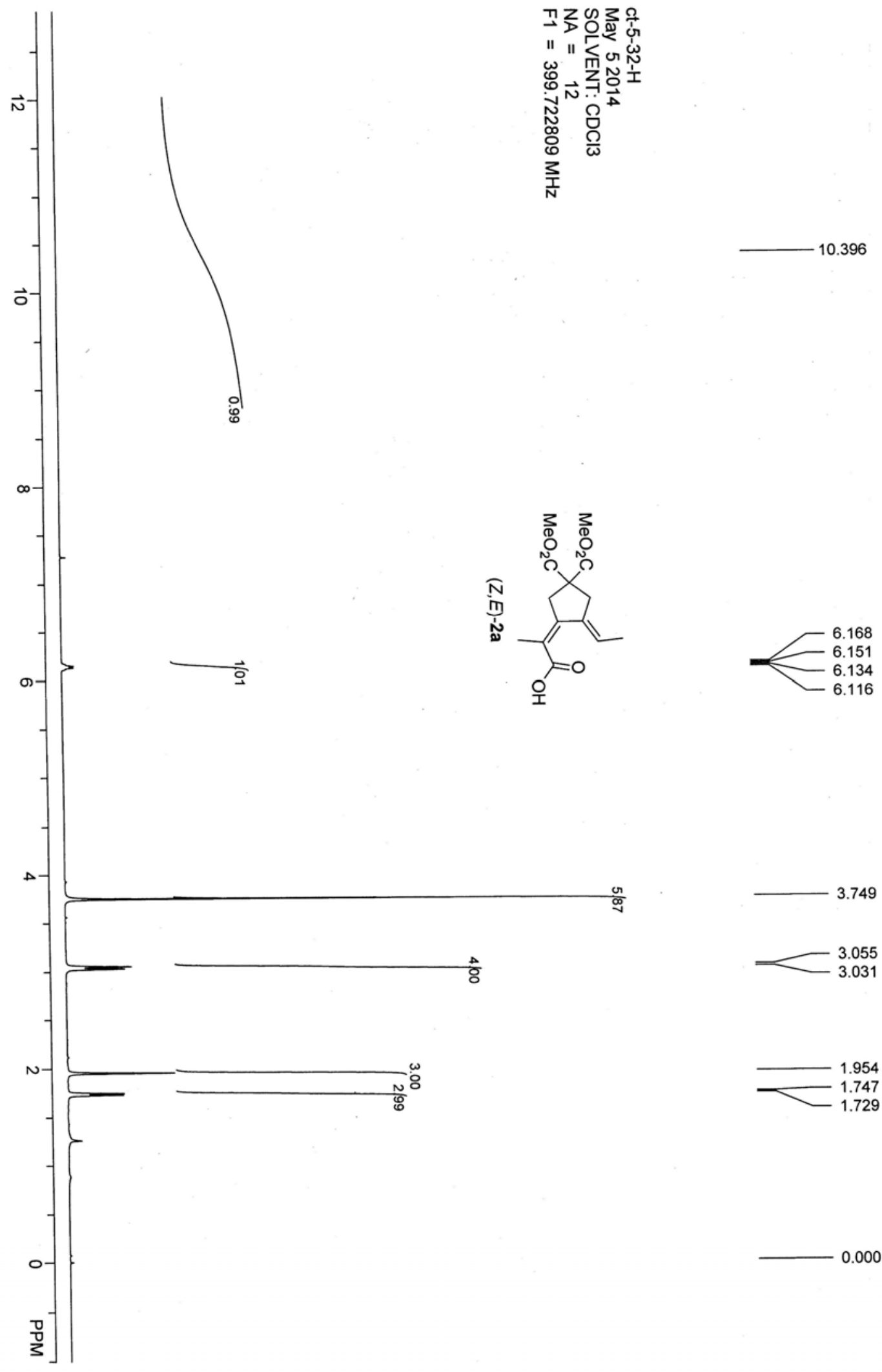

0.000 


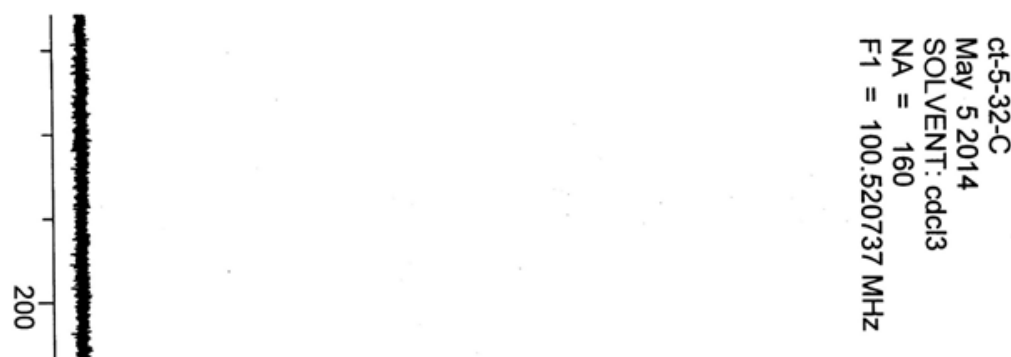

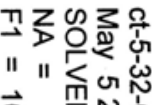

앙ㄱํำ

응

勇

방

허

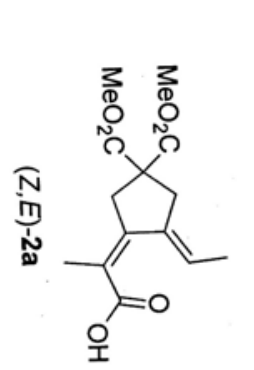

$-143.821$

$-134.917$

$-125.436$

$-119.060$
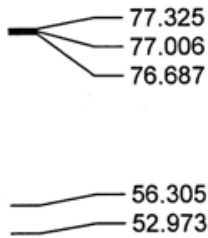

or
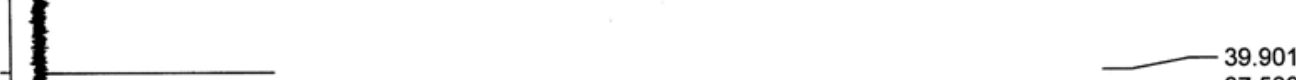

37.503

18.024

15.512

맘 

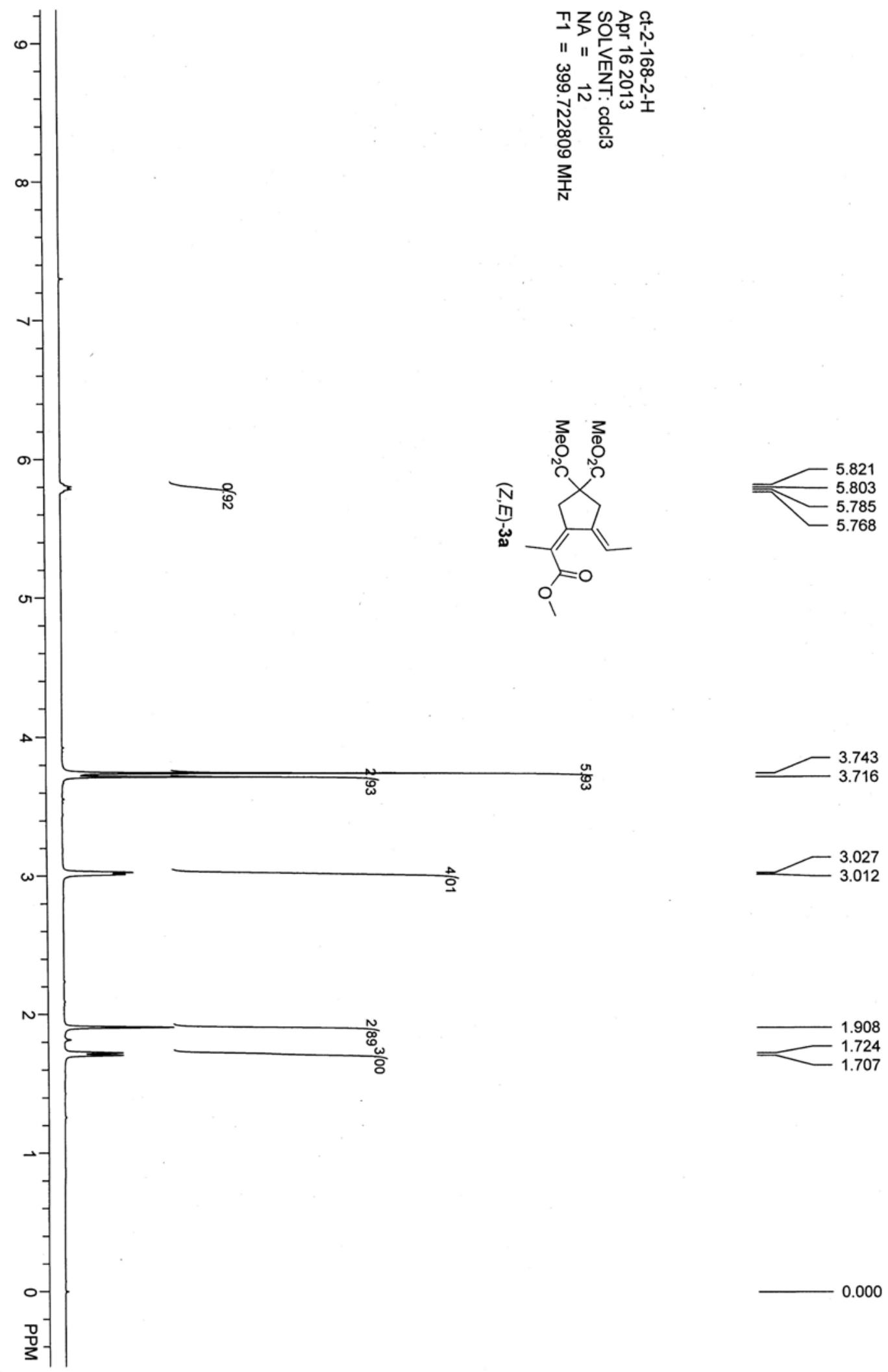

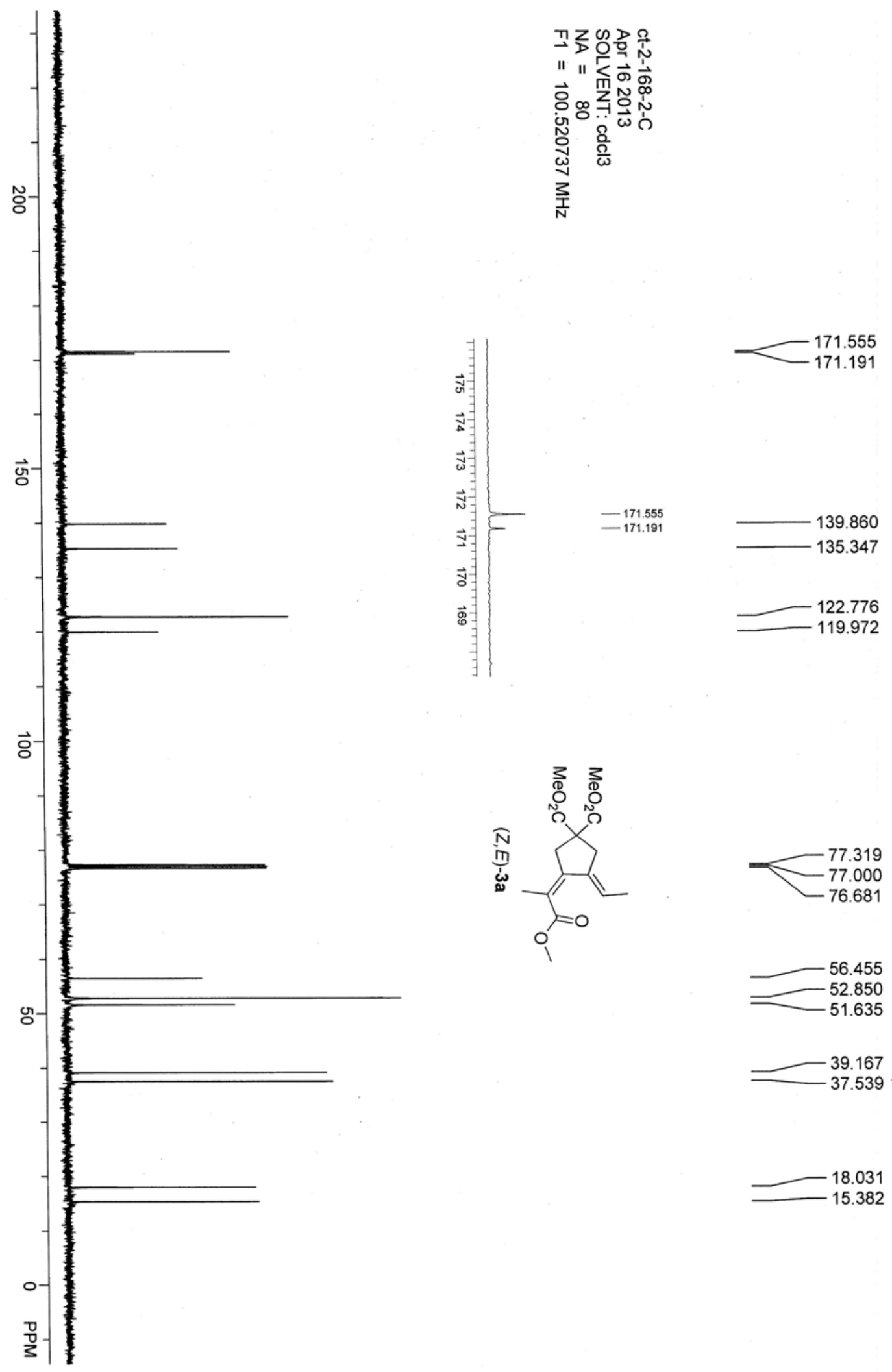


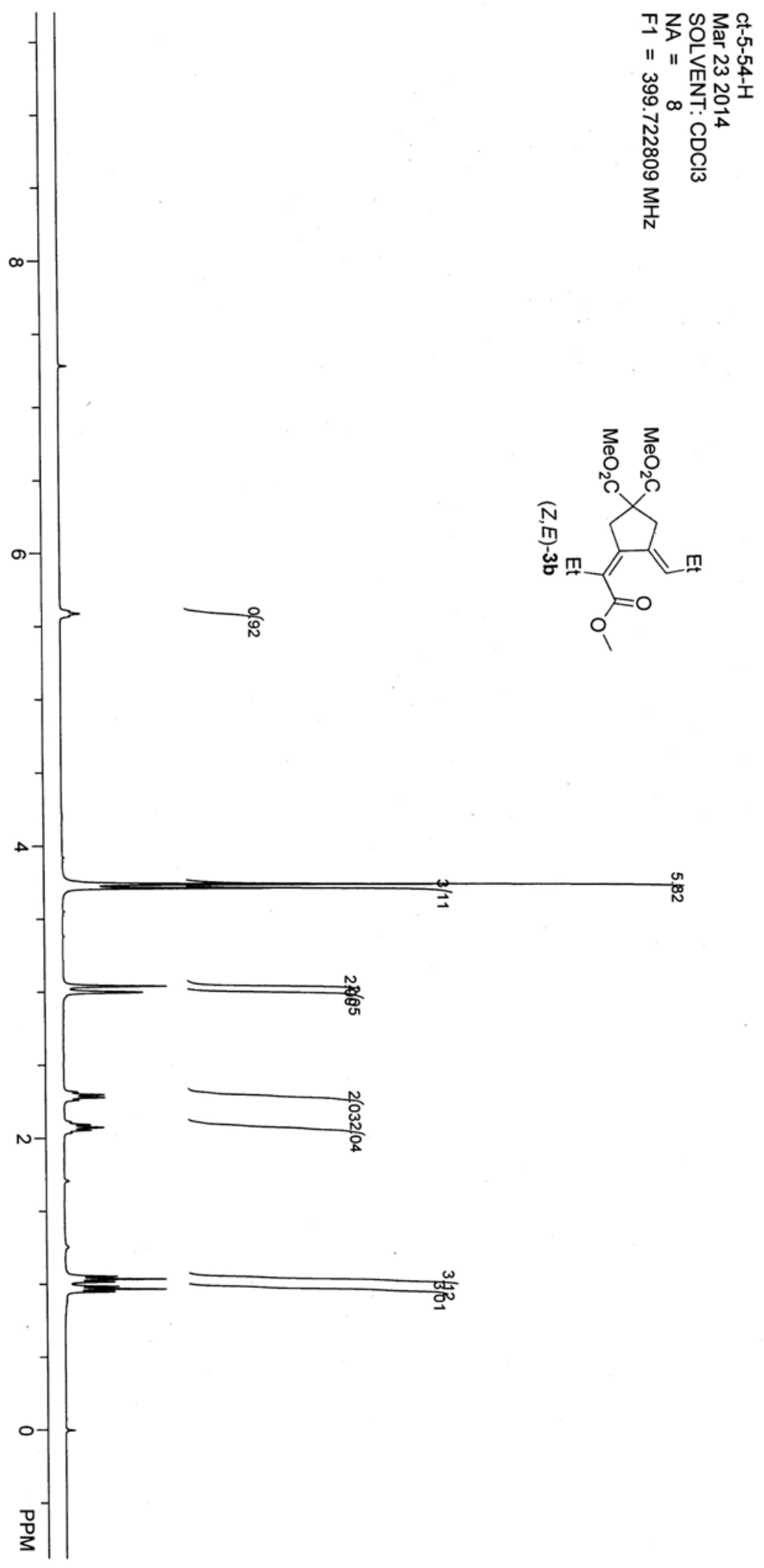

5.588
-5.570
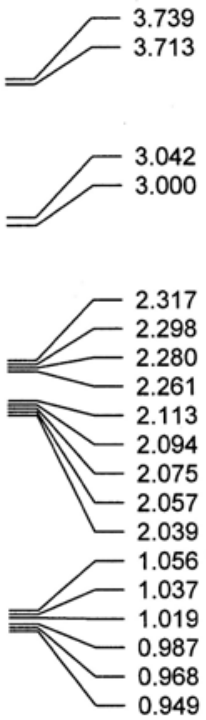

$-0.000$ 

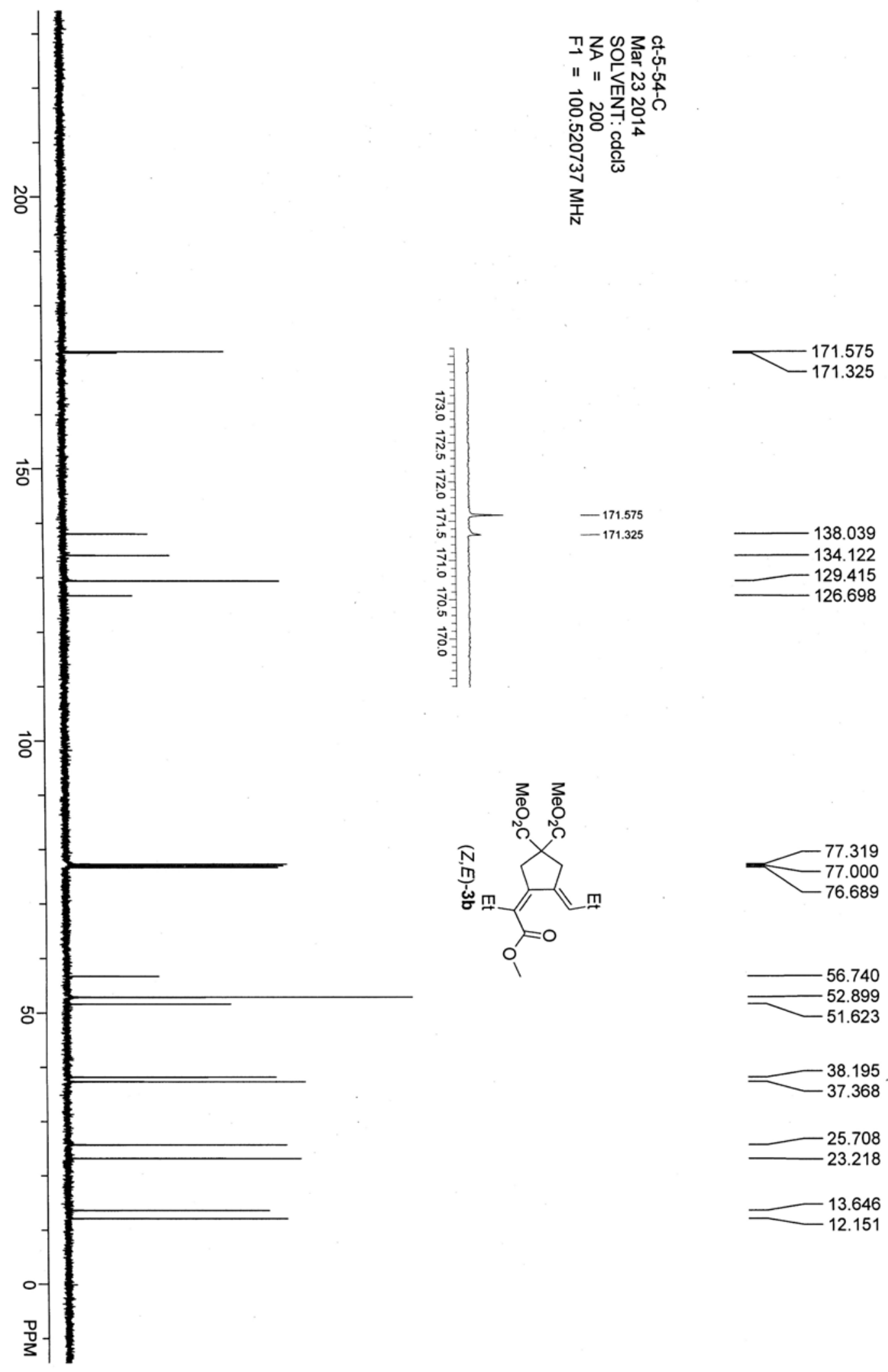

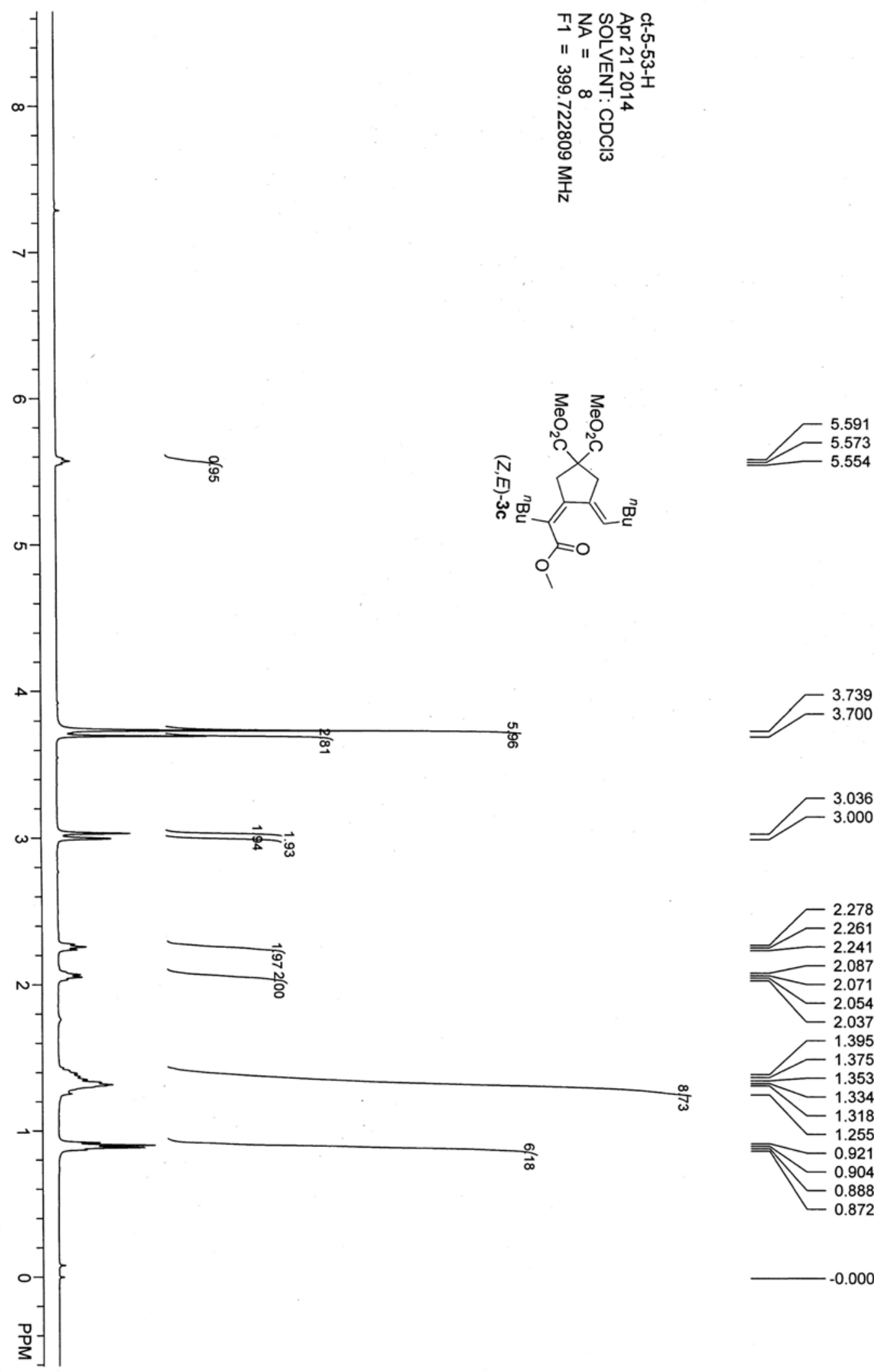

$-2.054$

2.037

$-1.395$

1.375

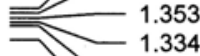

$-1.318$

$-1.255$

0.921
0.904

0.888

$-0.872$

$-0.000$ 

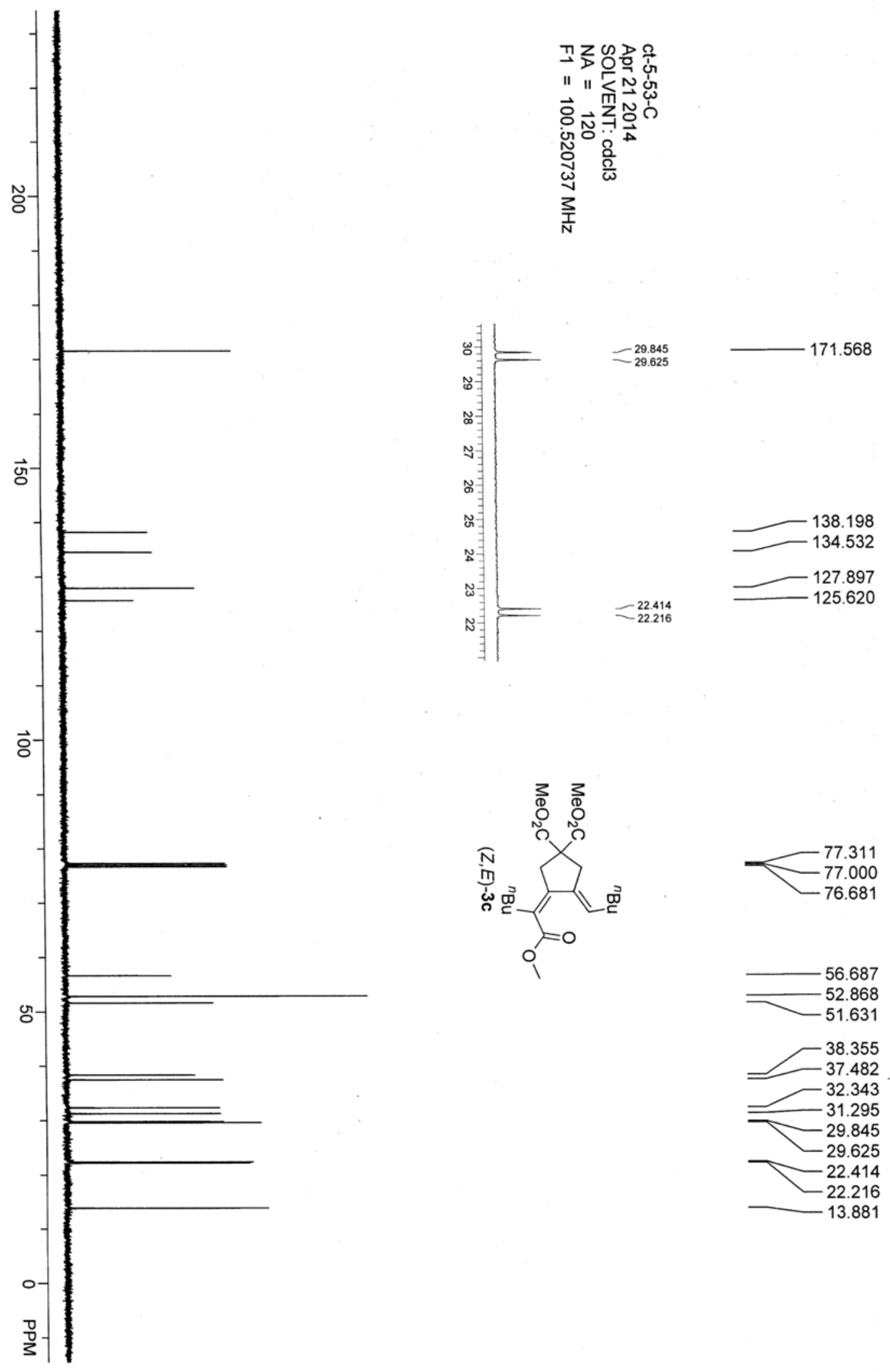

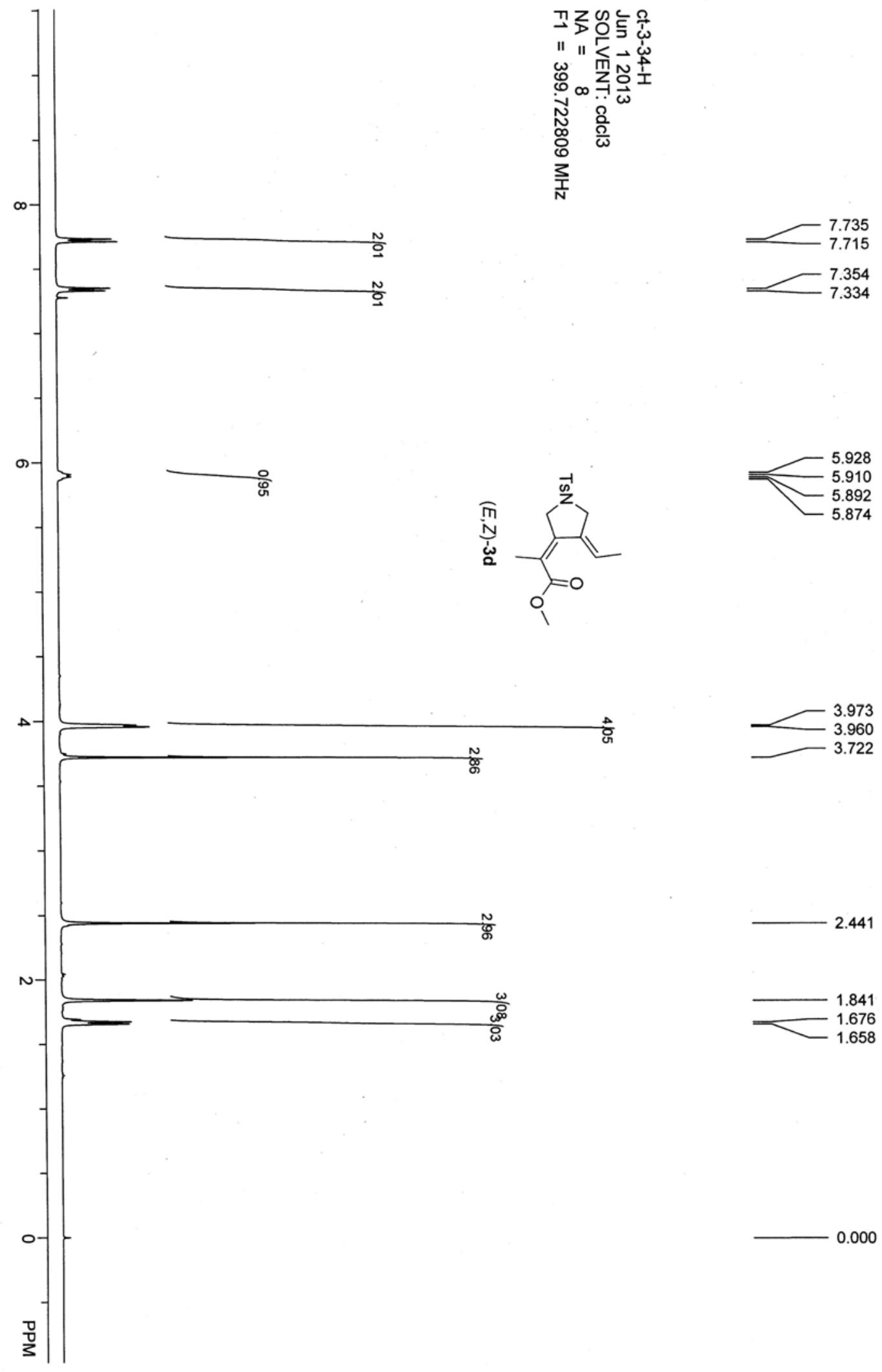

0.000 

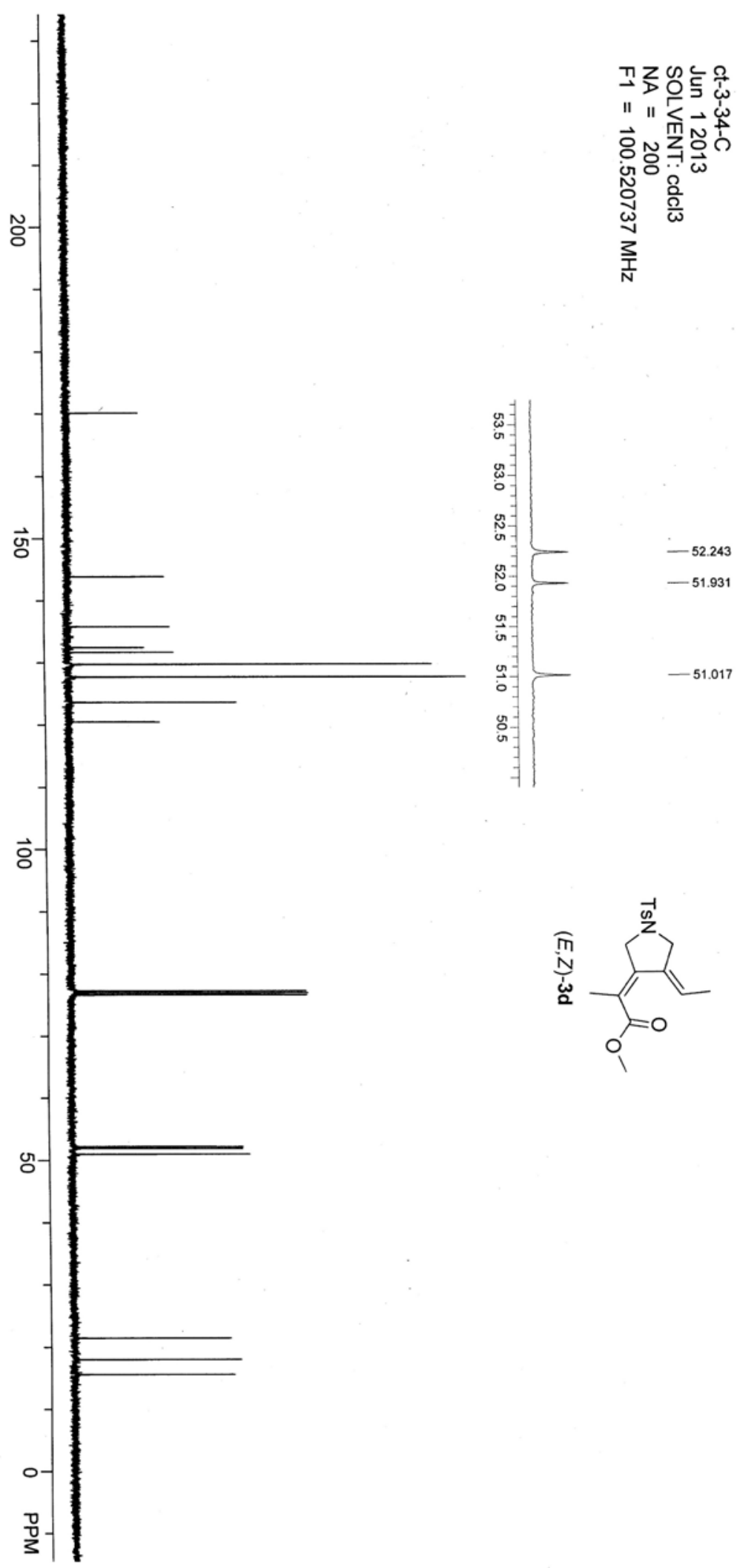

$-170.124$

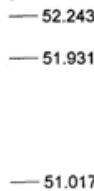

143.902

135.836

$-132.474$ 131.703

$-51.017$

129.749

$-127.692$

123.611

120.499<smiles>CC=C1C[C](C)CC1=C(C)C(=O)OC</smiles>

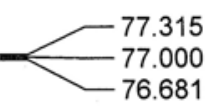

52.243

51.931

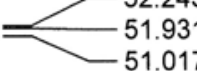

21.477

18.027

15.643

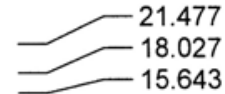



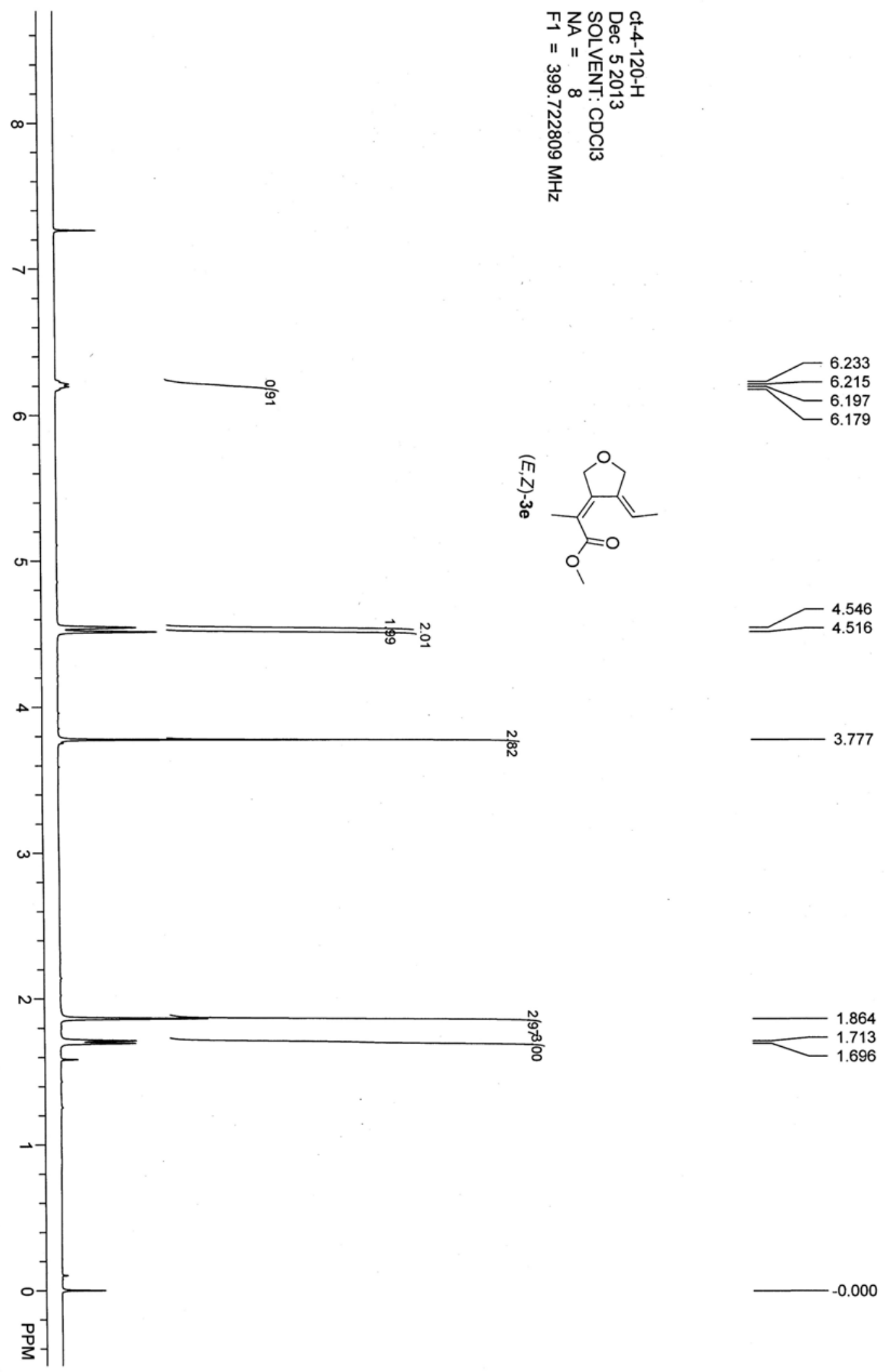


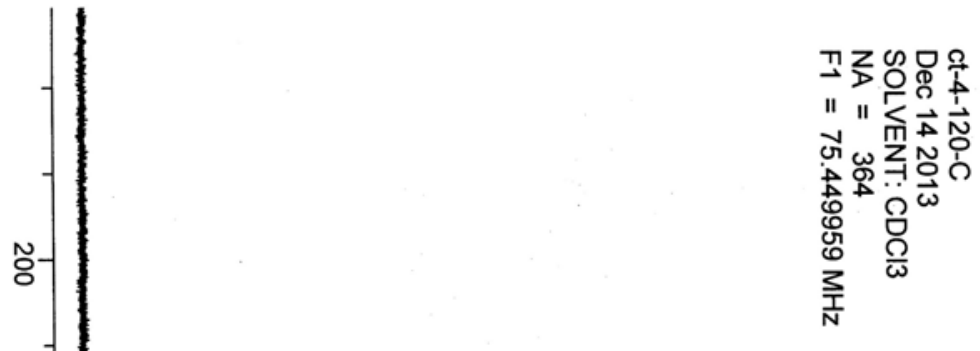

169.775

용

하
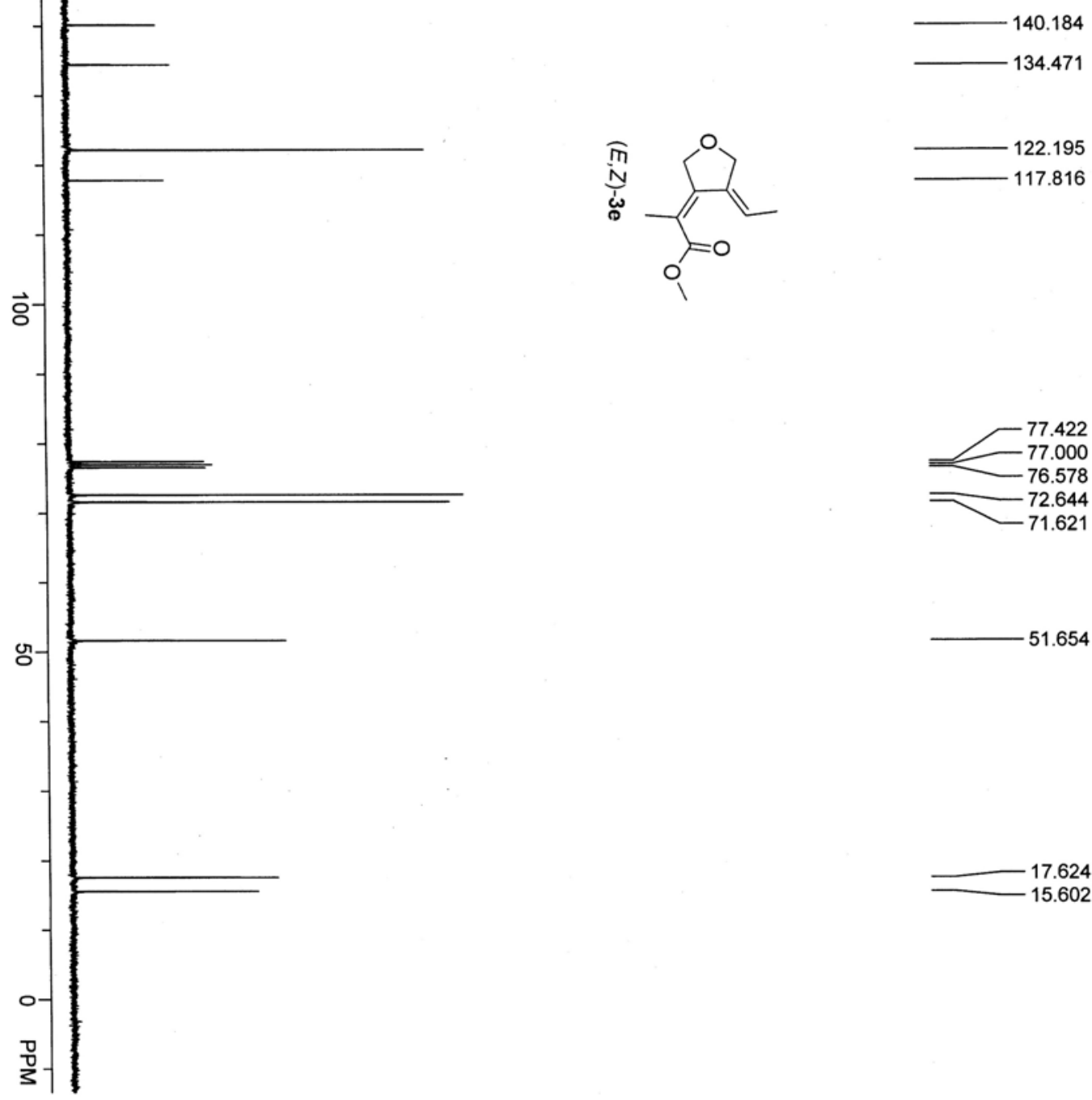

17.624
-15.602 

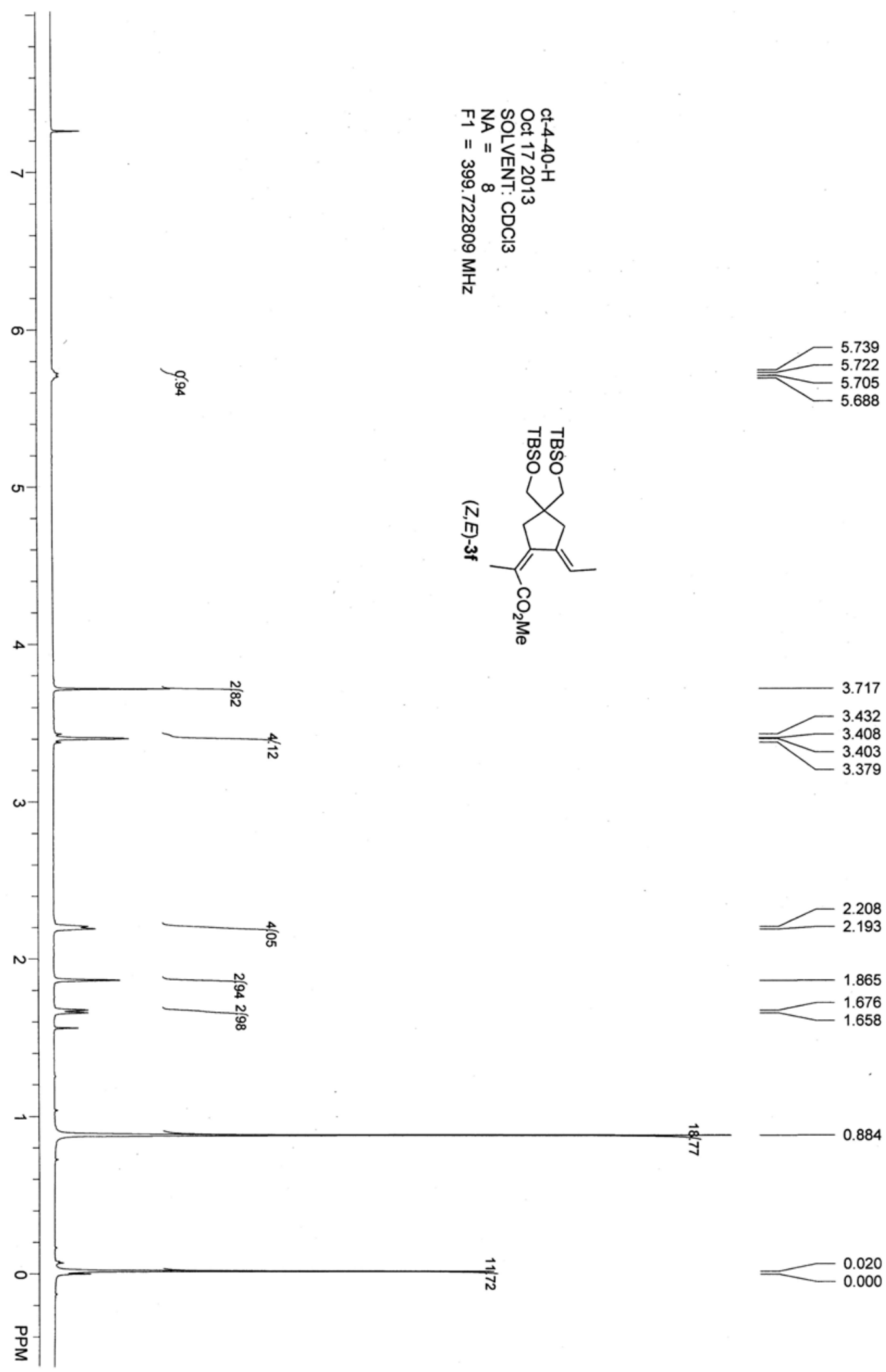


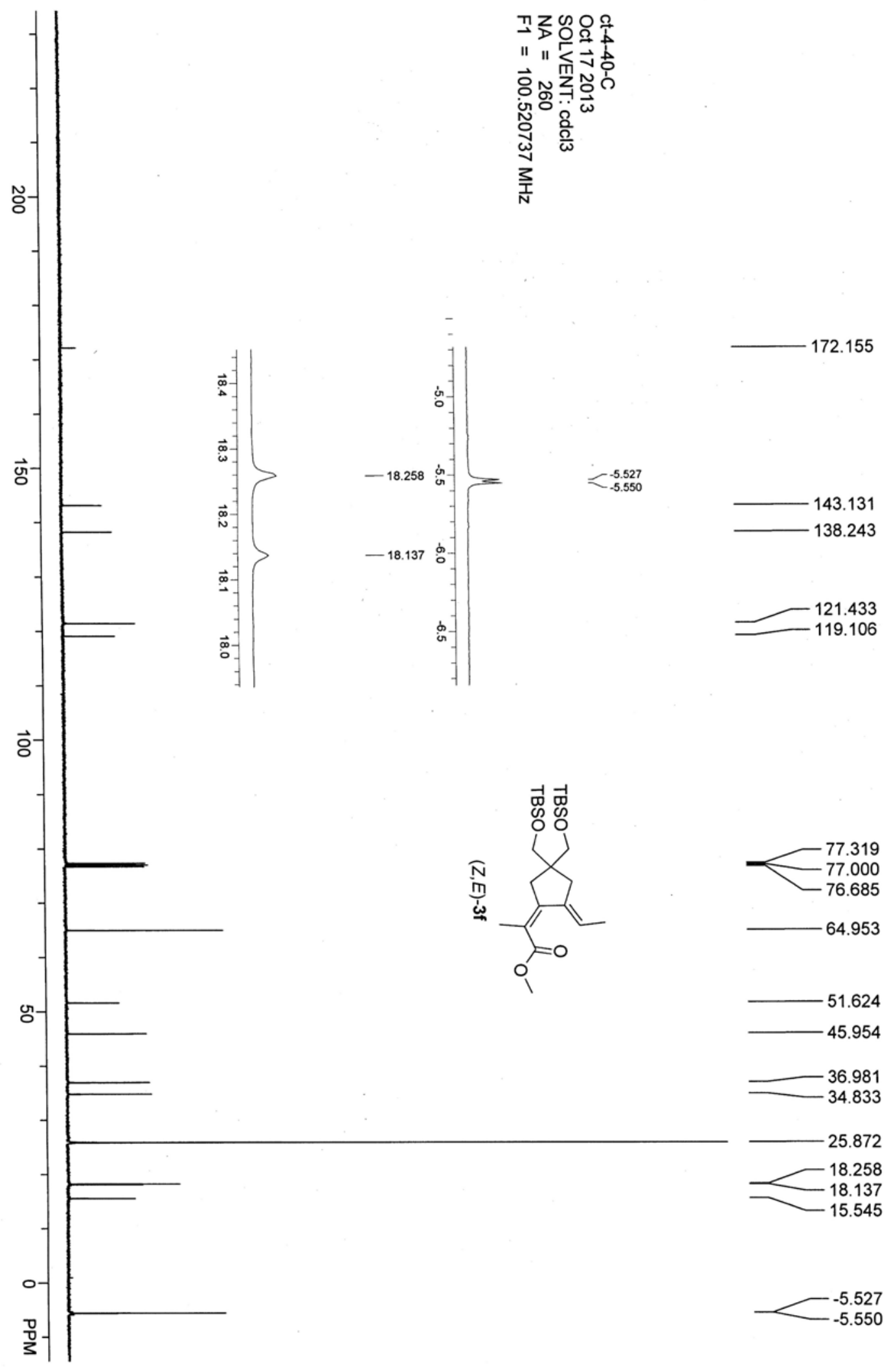




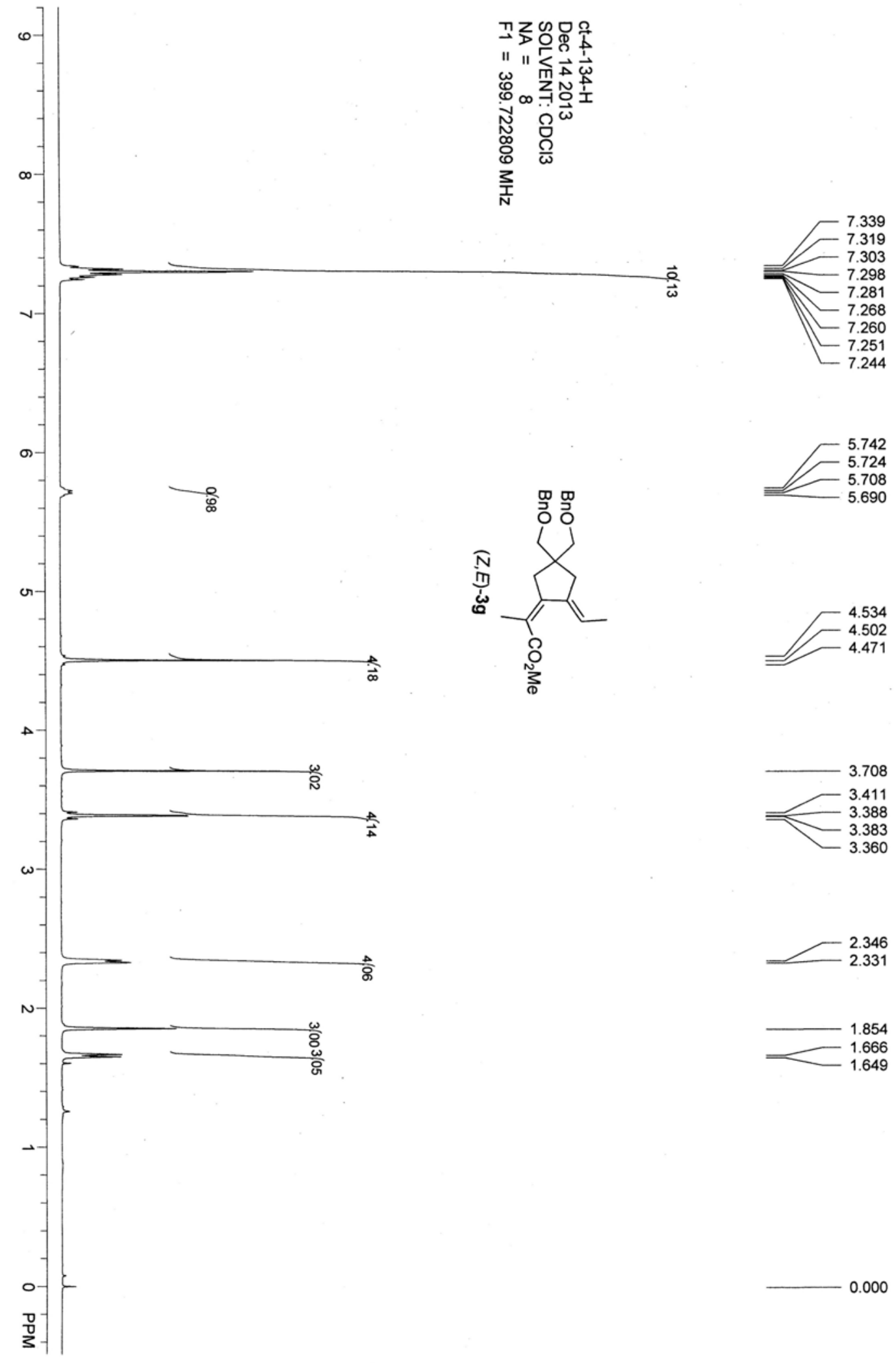




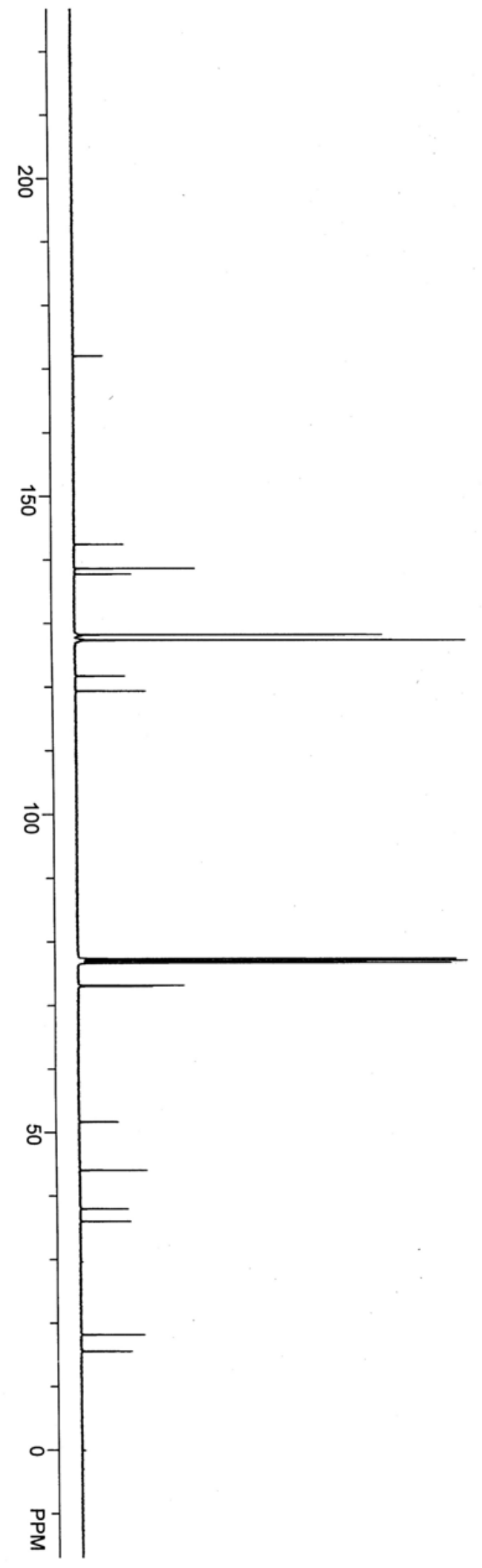

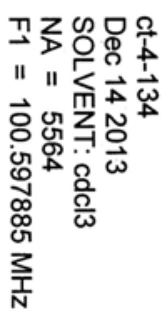

172.051
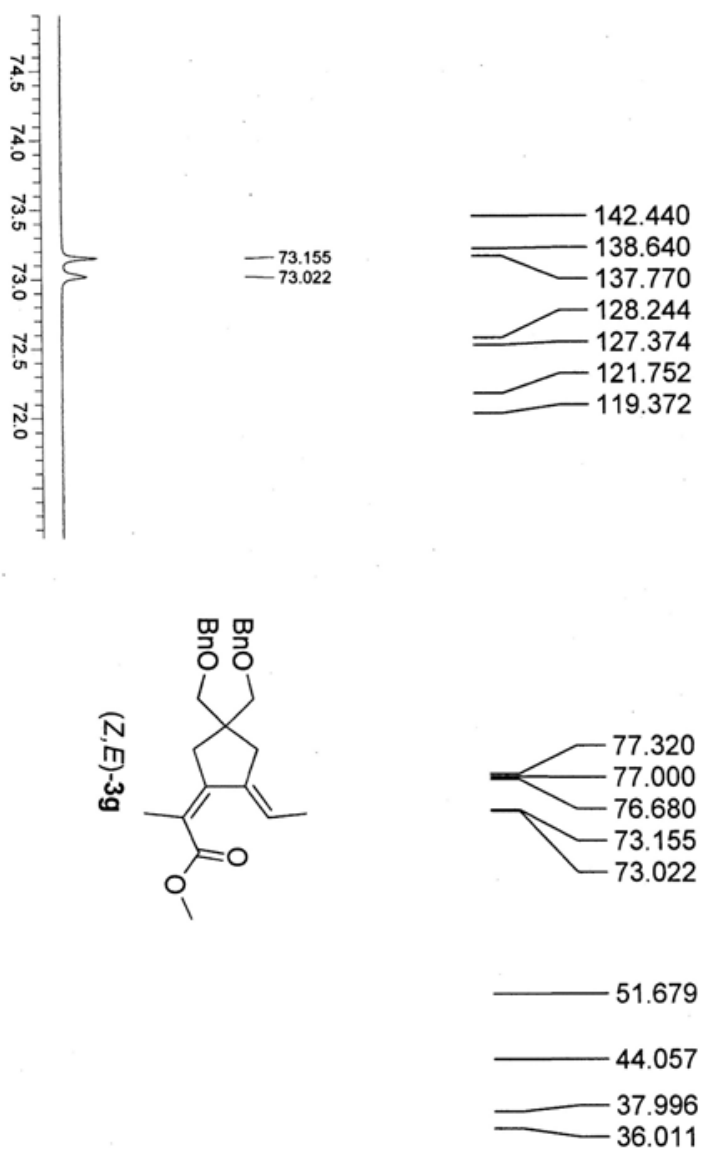

$-18.178$

15.568 

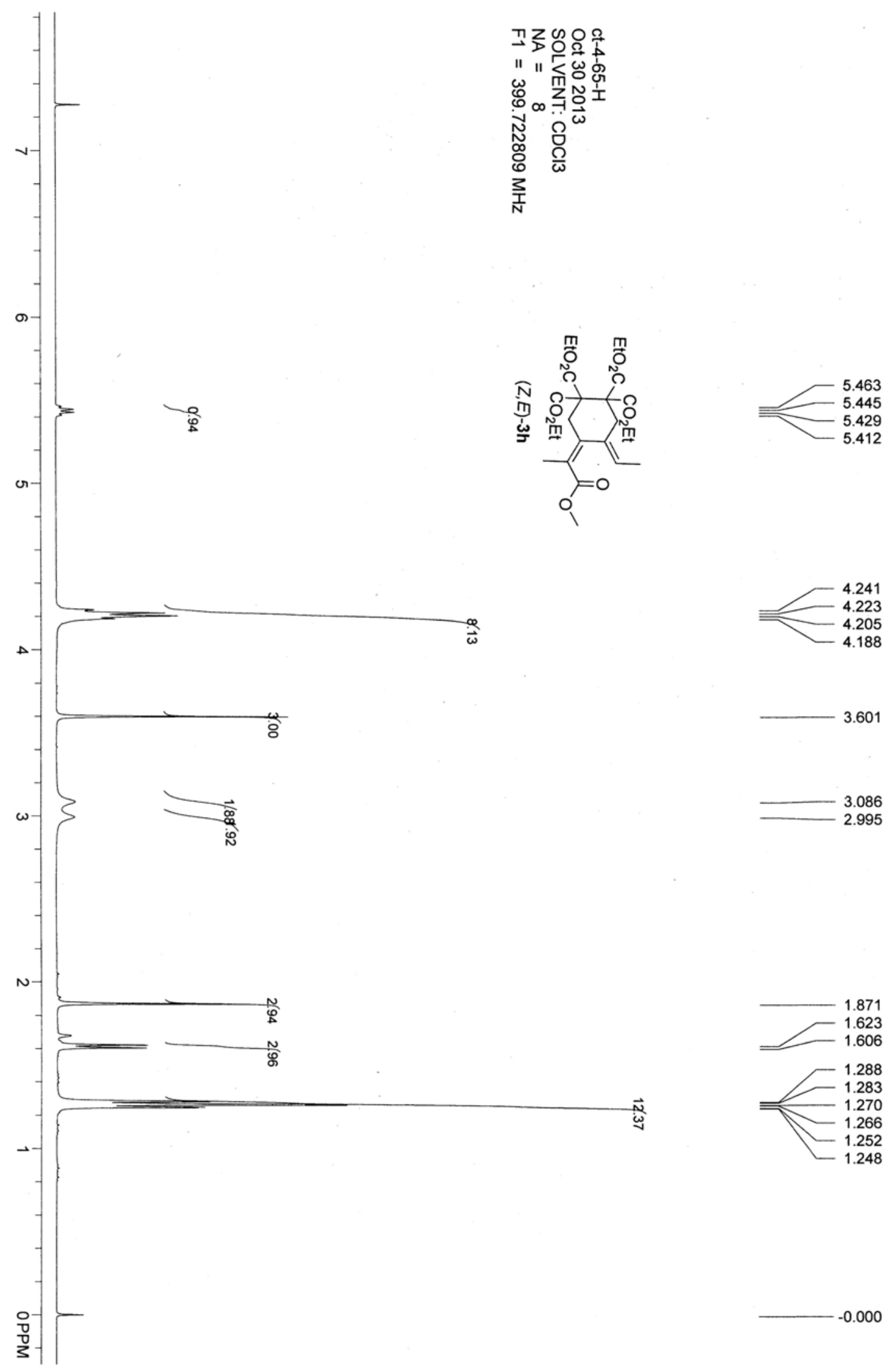

3.601

3.086

2.995

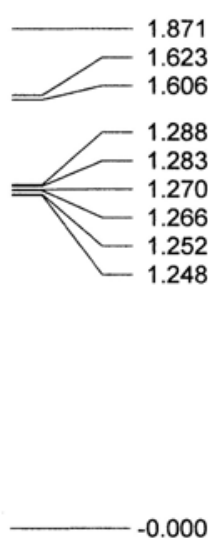




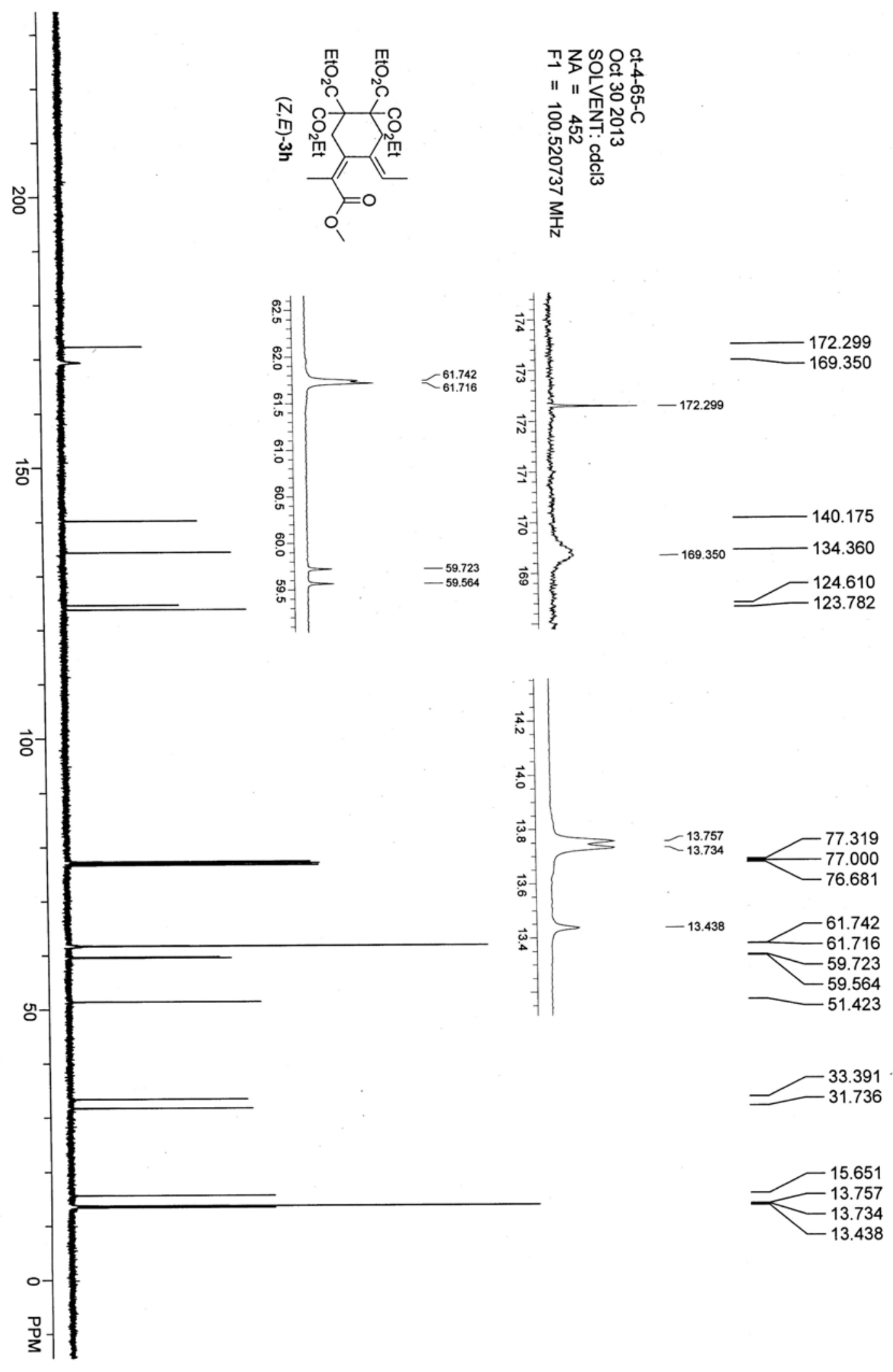



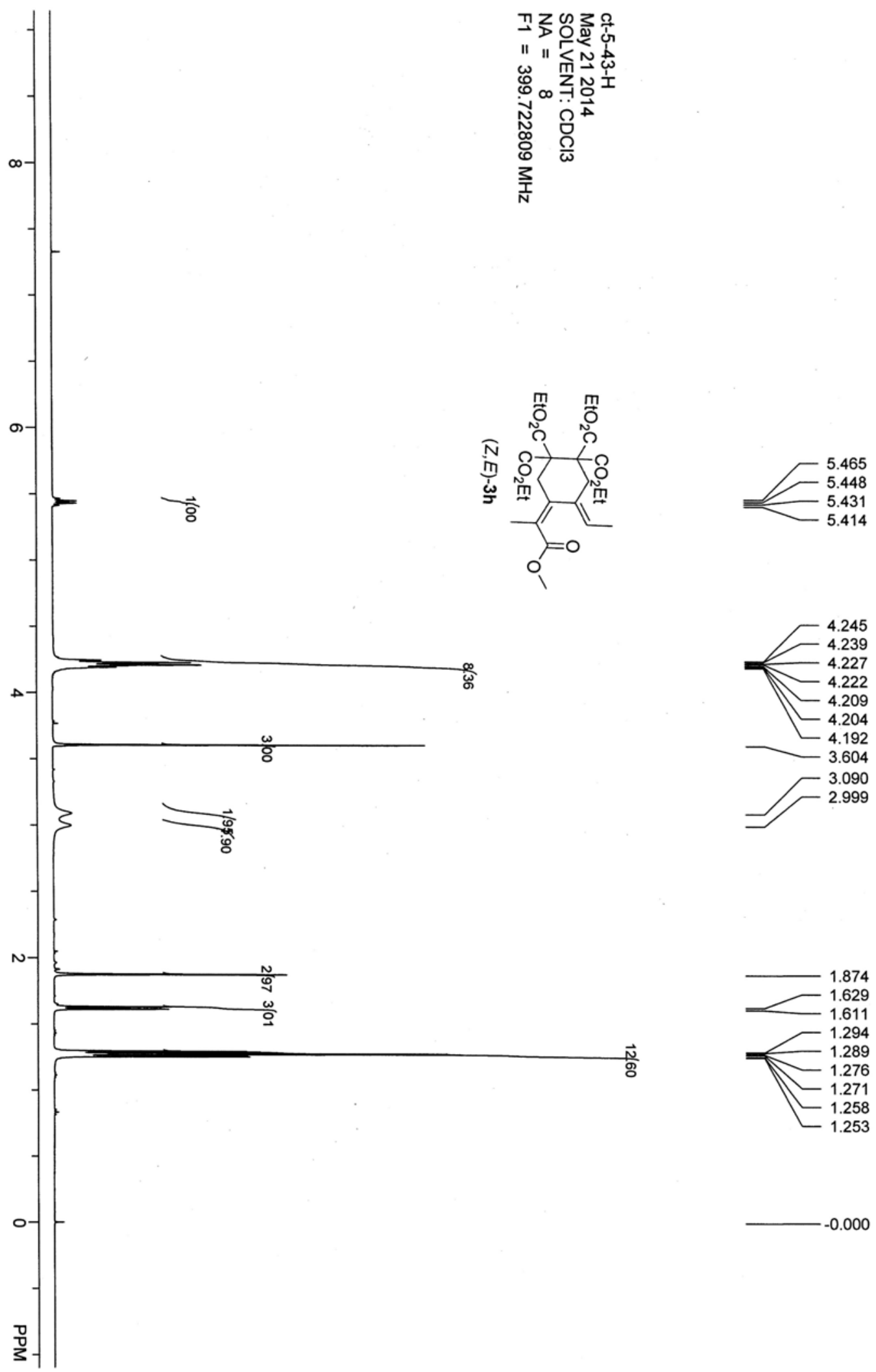

$-0.000$ 


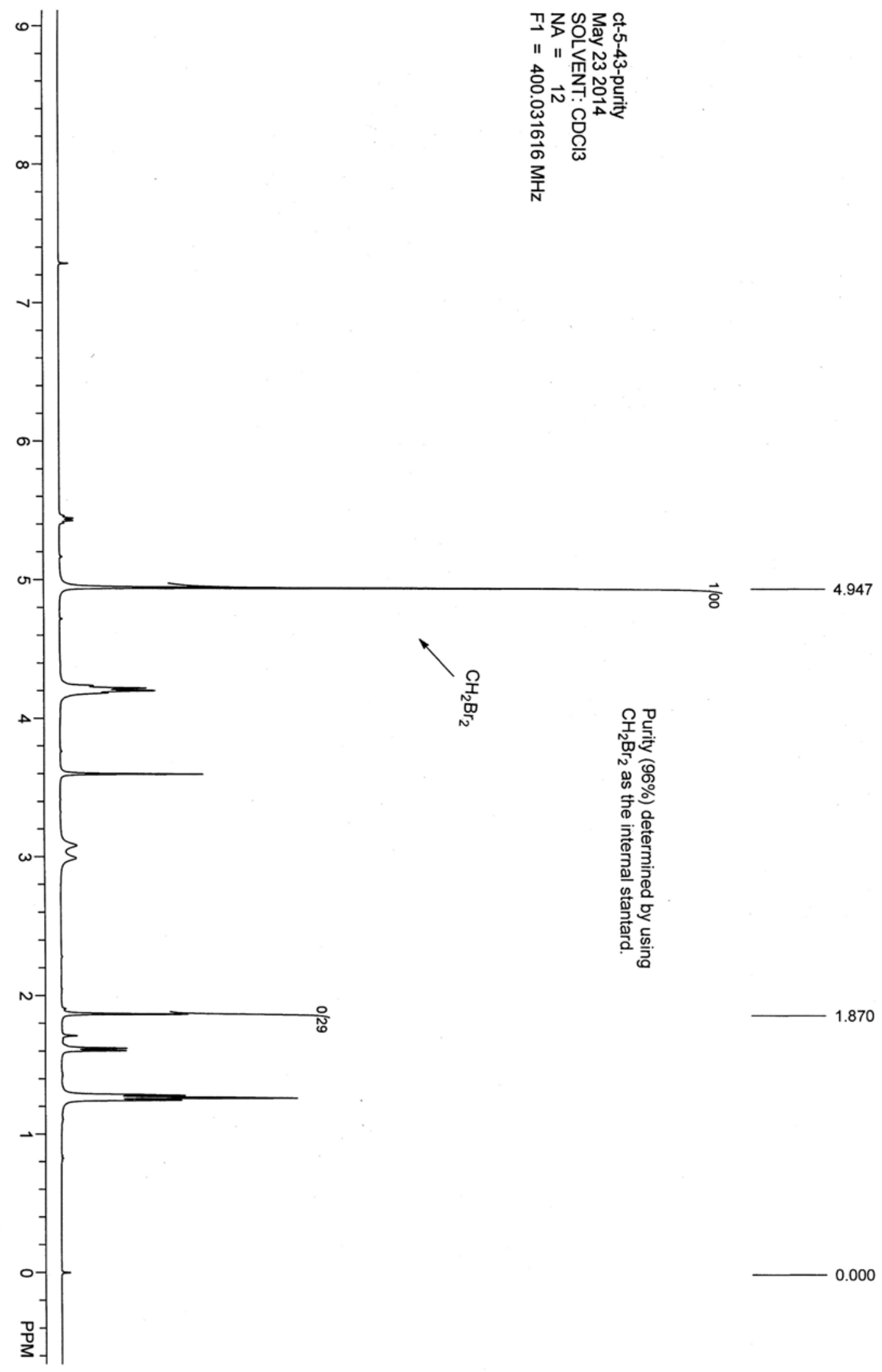




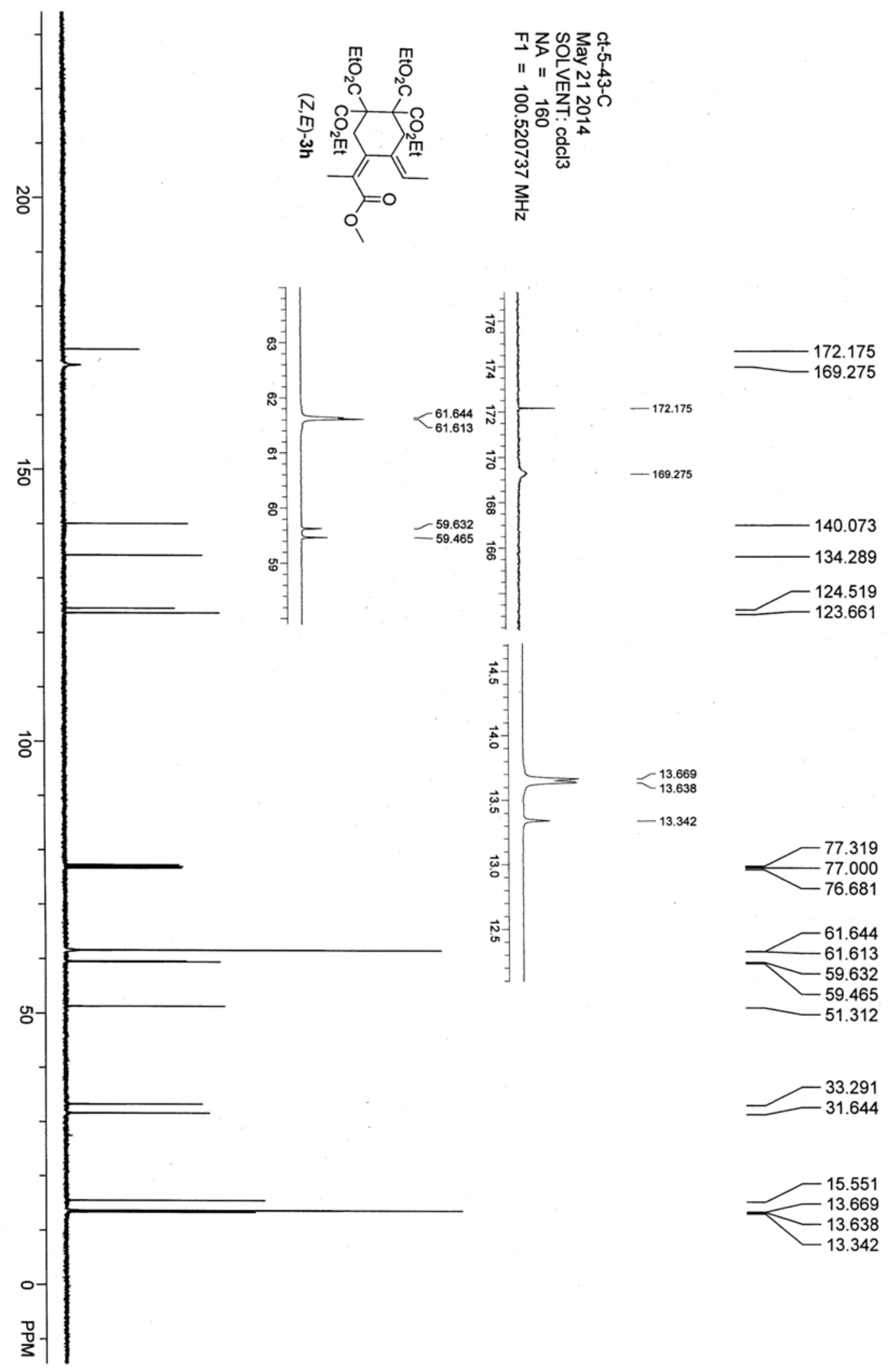



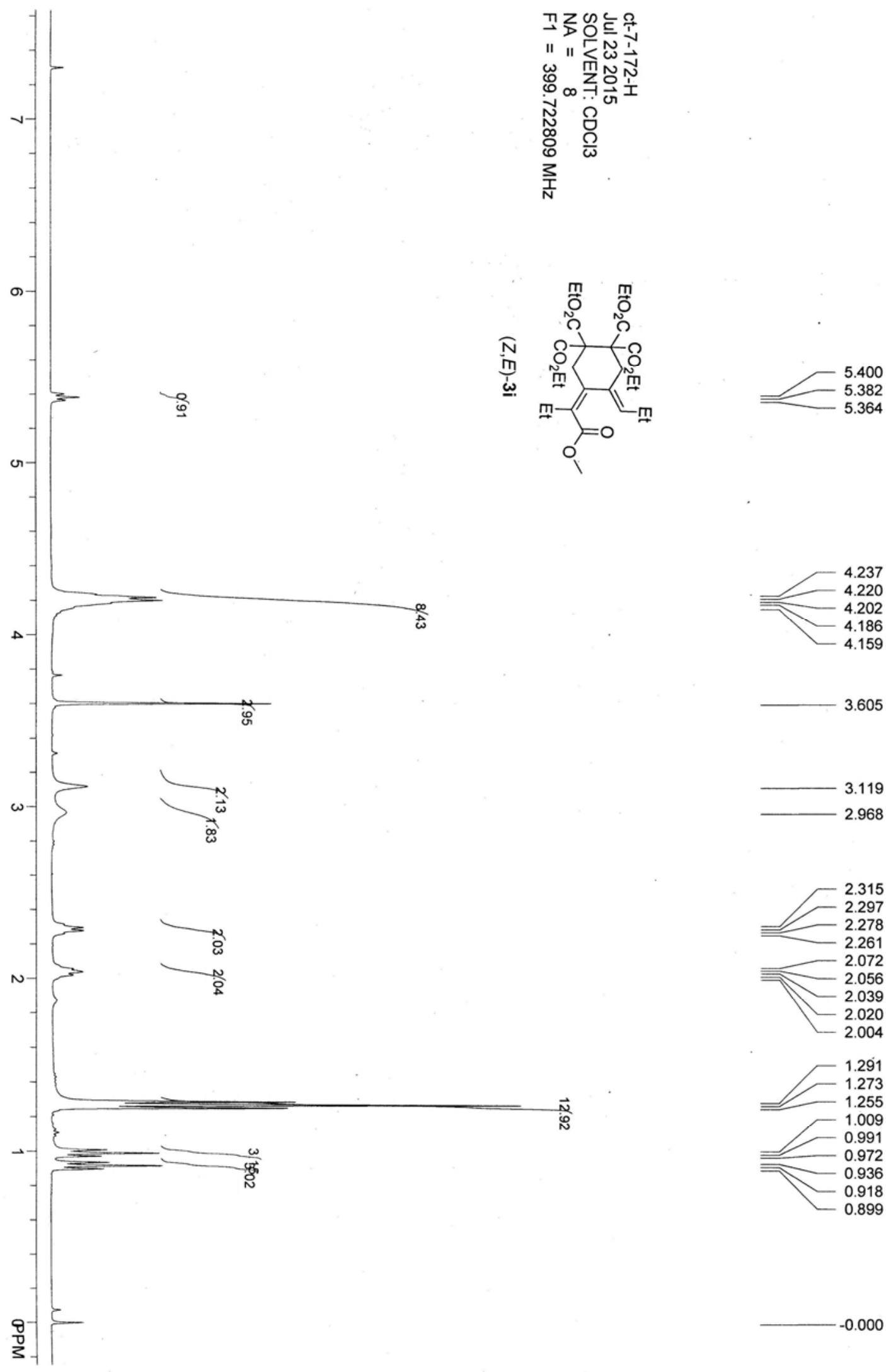

3.605

2.968

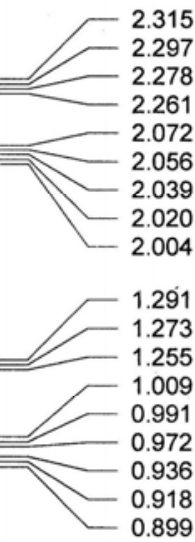

$-0.000$ 

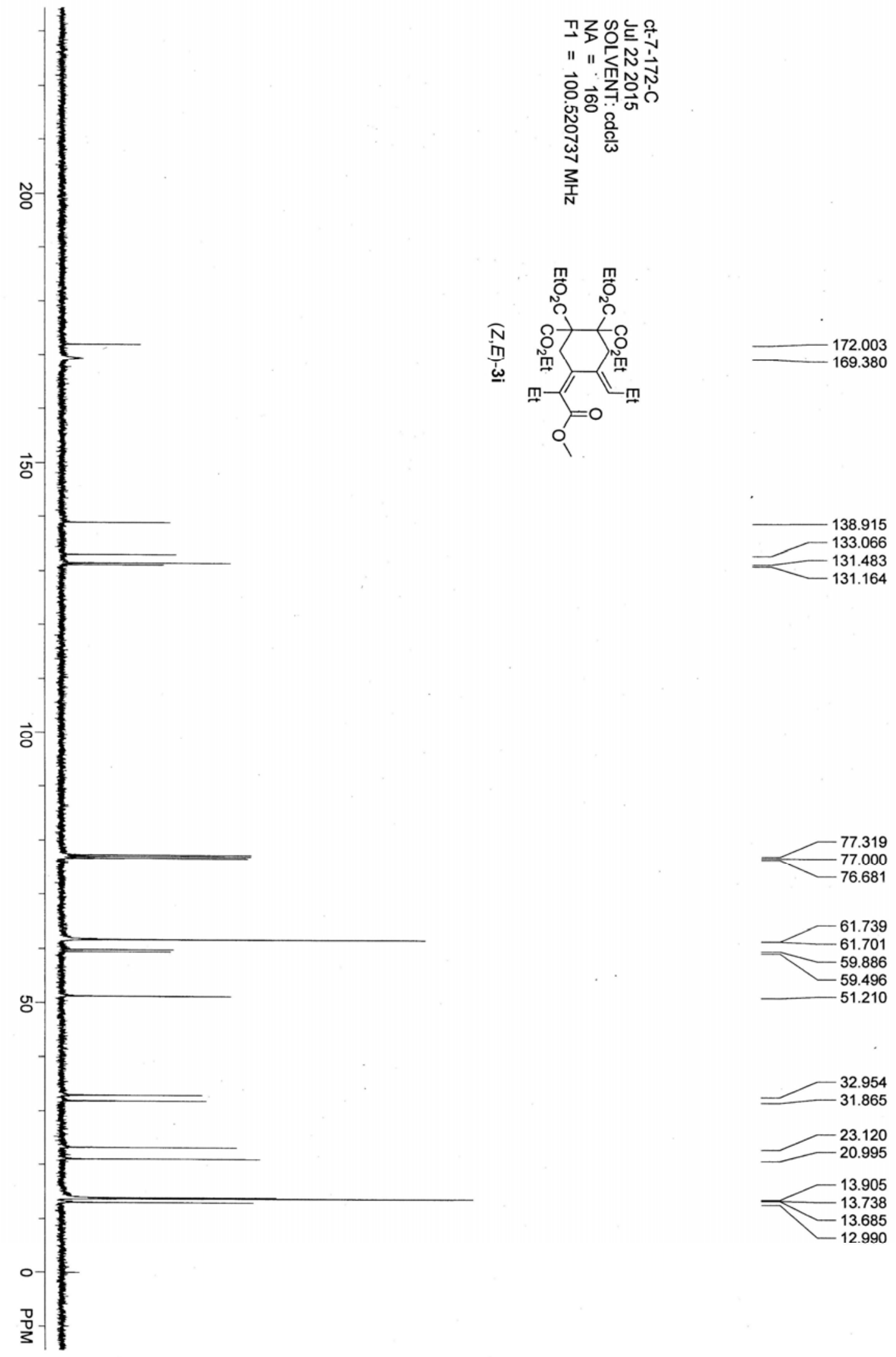

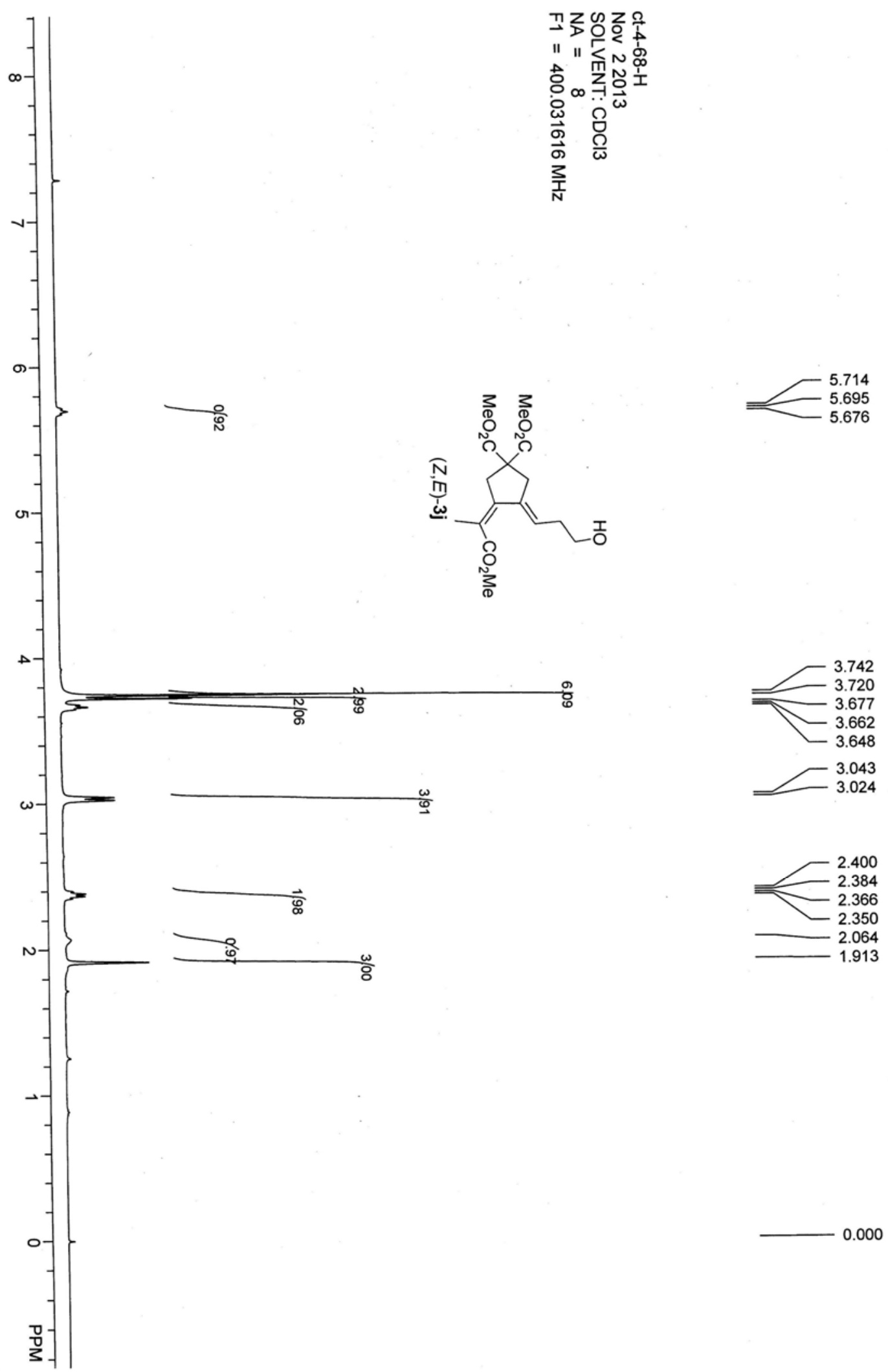

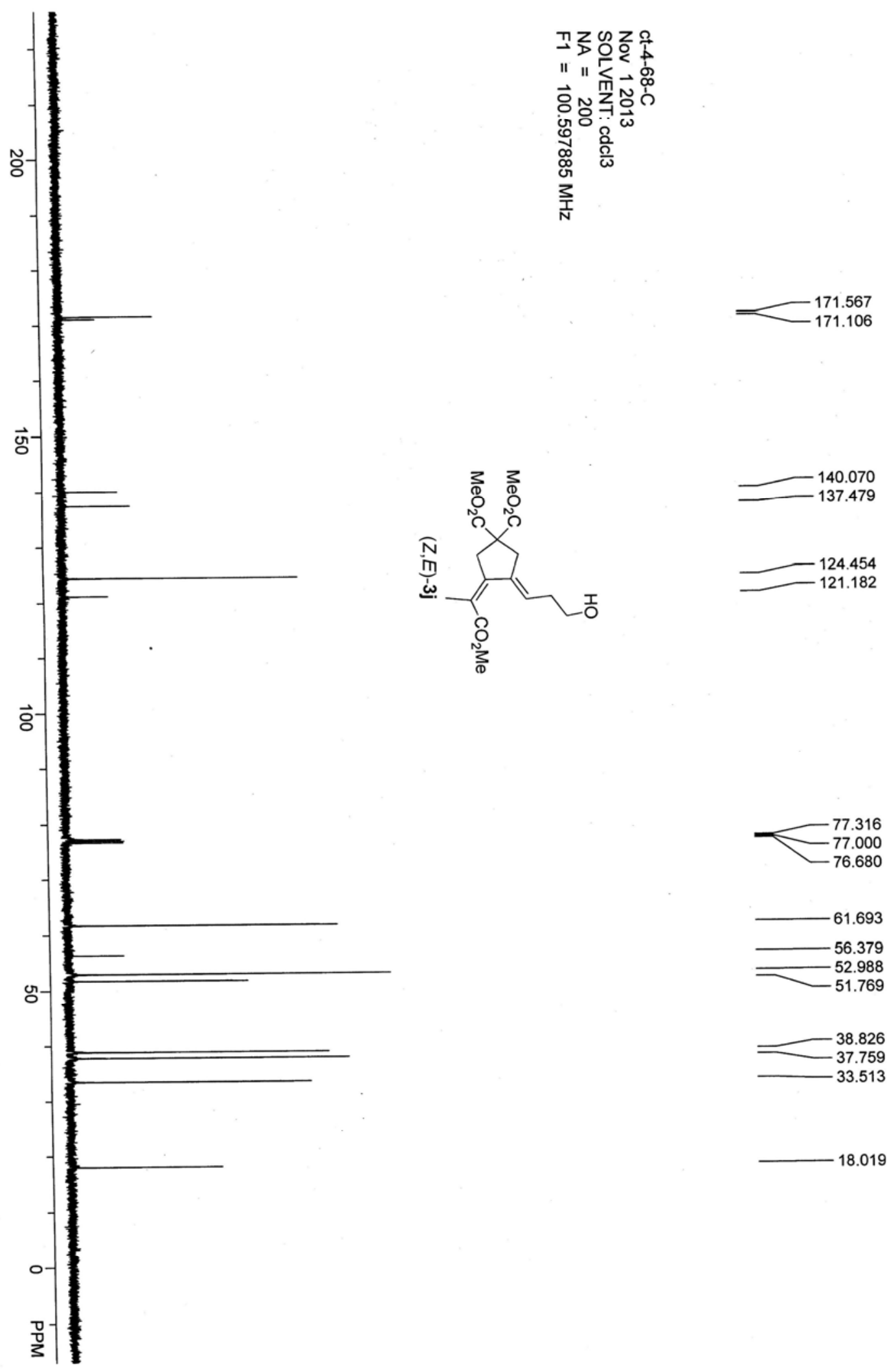

33.513

18.019 

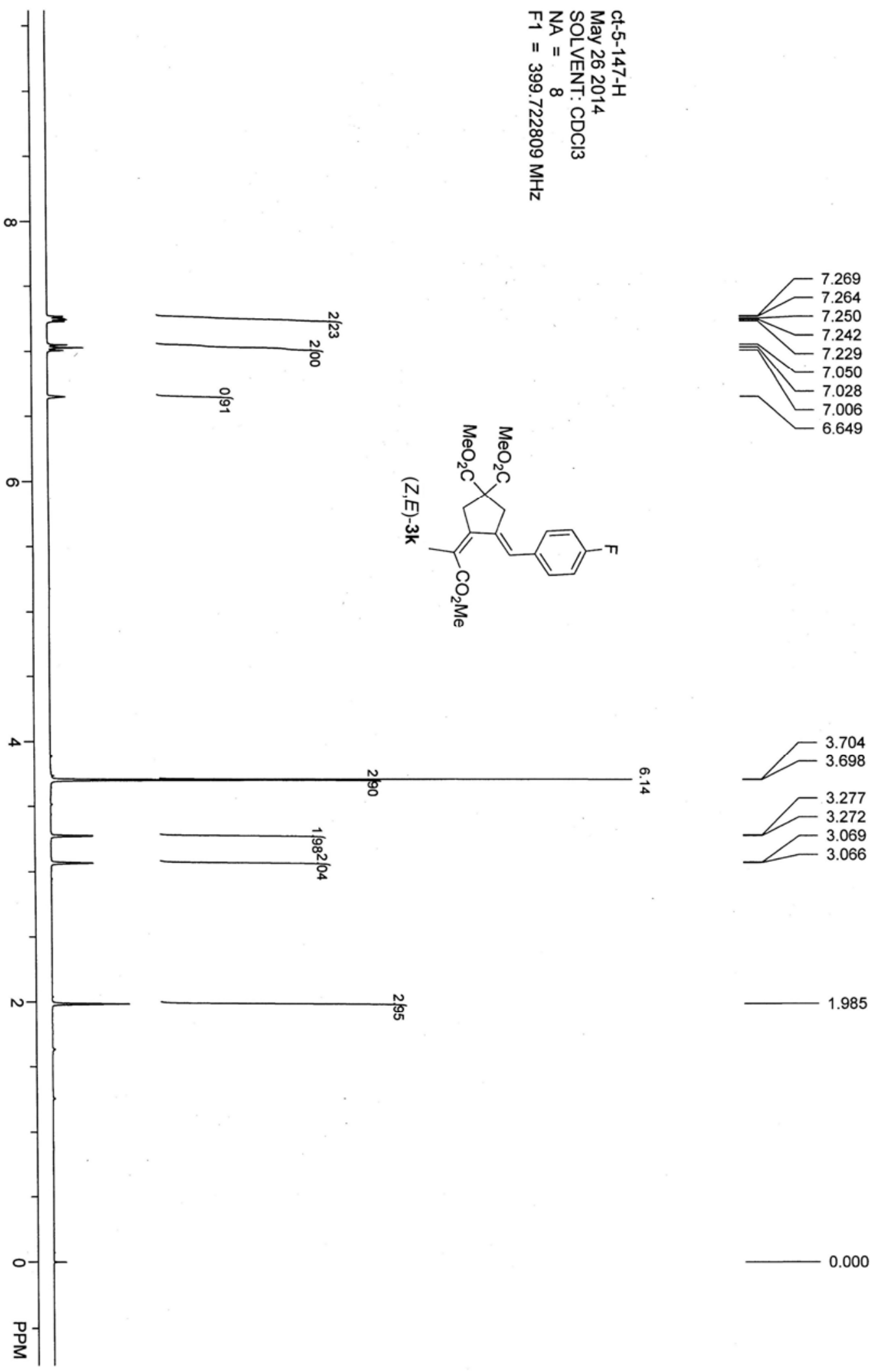

0.000 


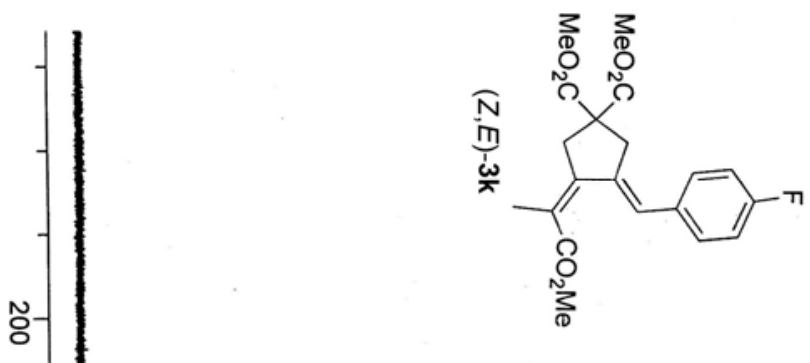

항

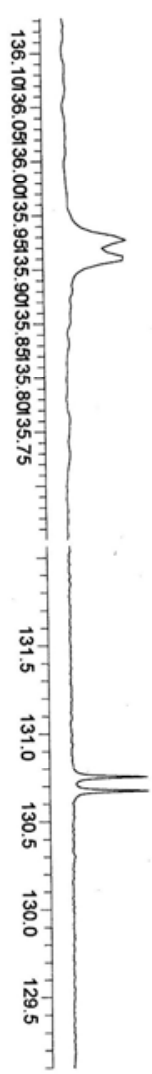

in-

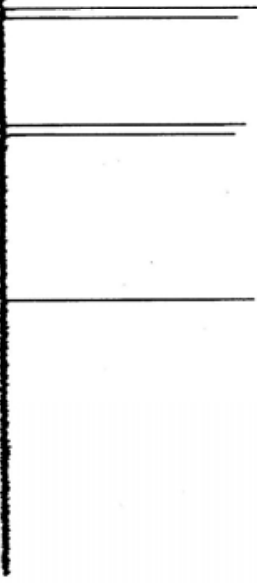

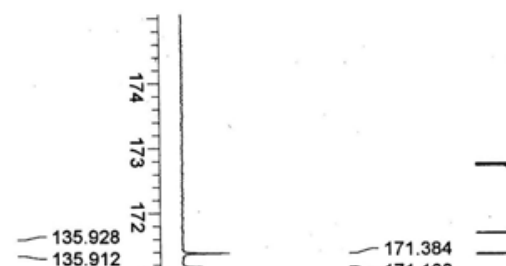

171.384
-171.168

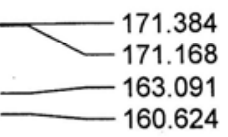

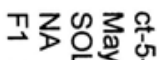

" "

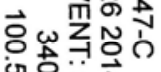

임 $\vec{A}$

嵌 $\frac{\circ}{\omega}$

곤

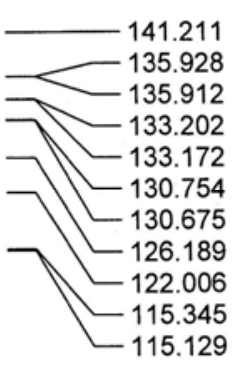

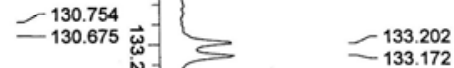

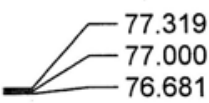

$\overrightarrow{0}$

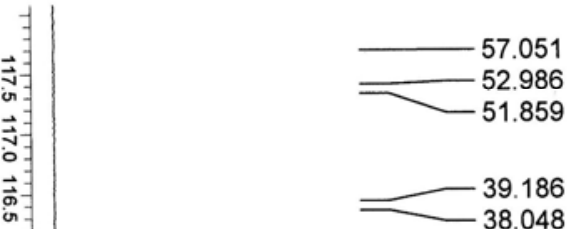

L

$-115.129$

18.342 


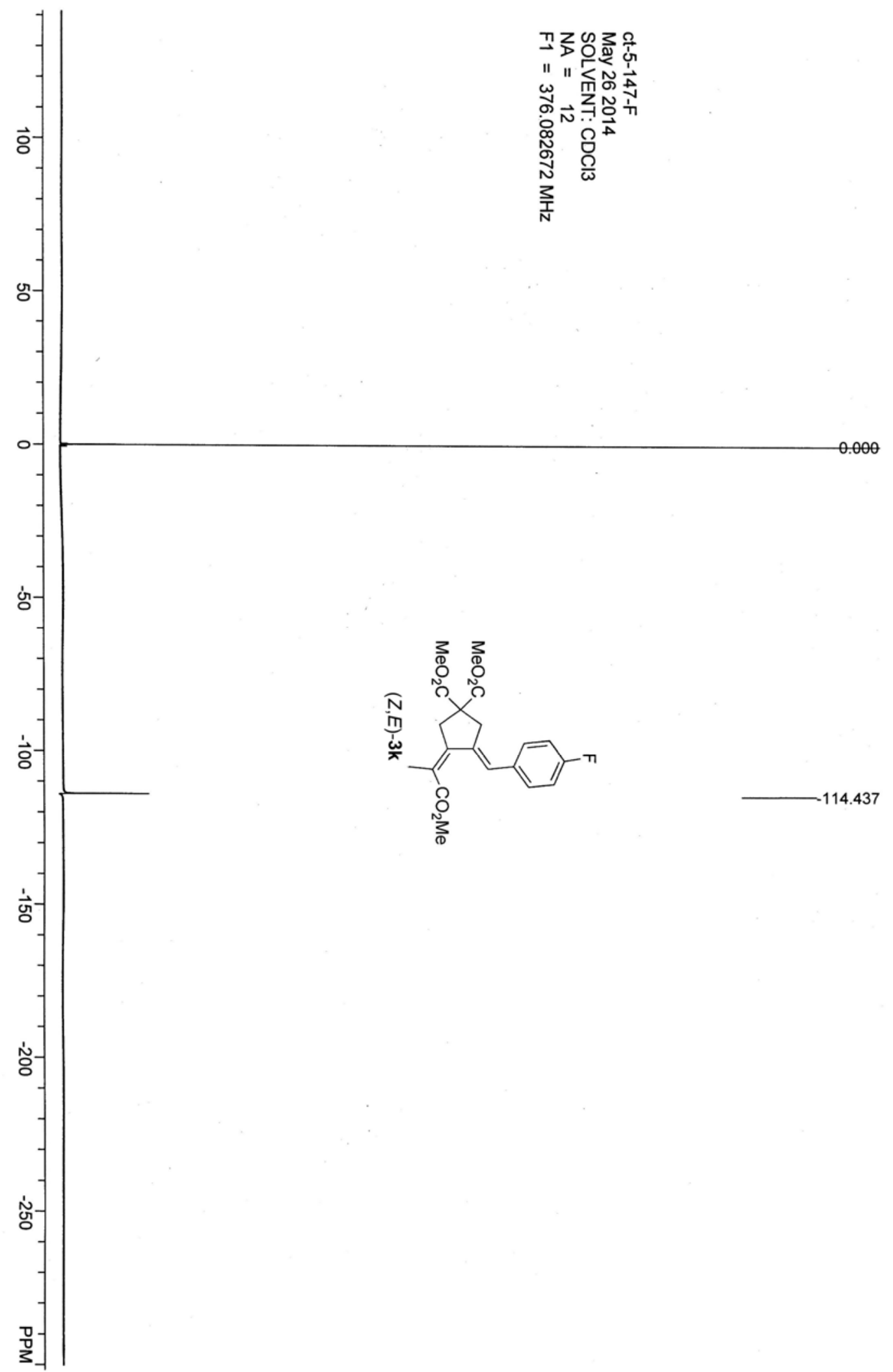



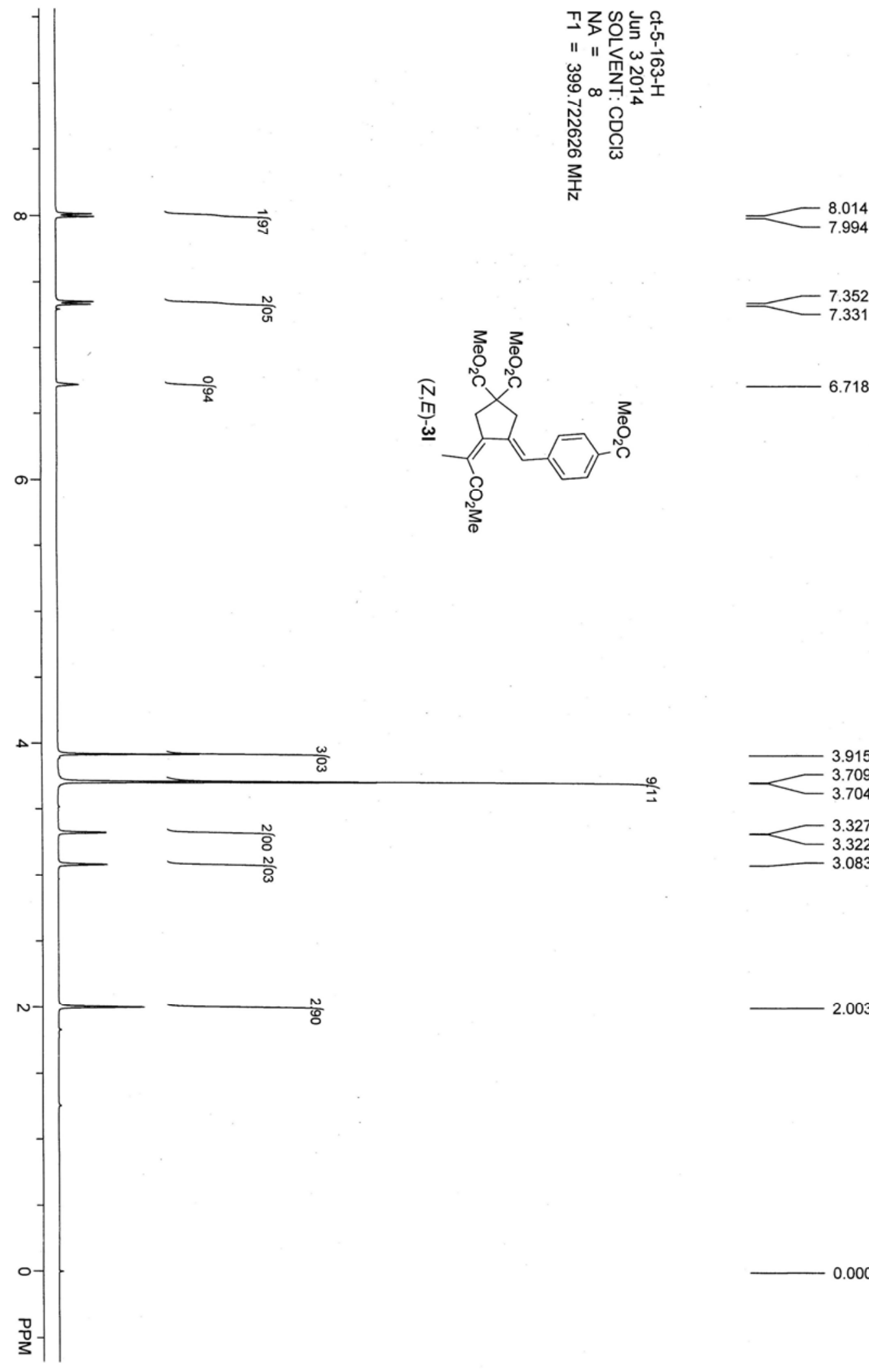

6.718

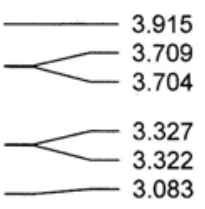

2.003 

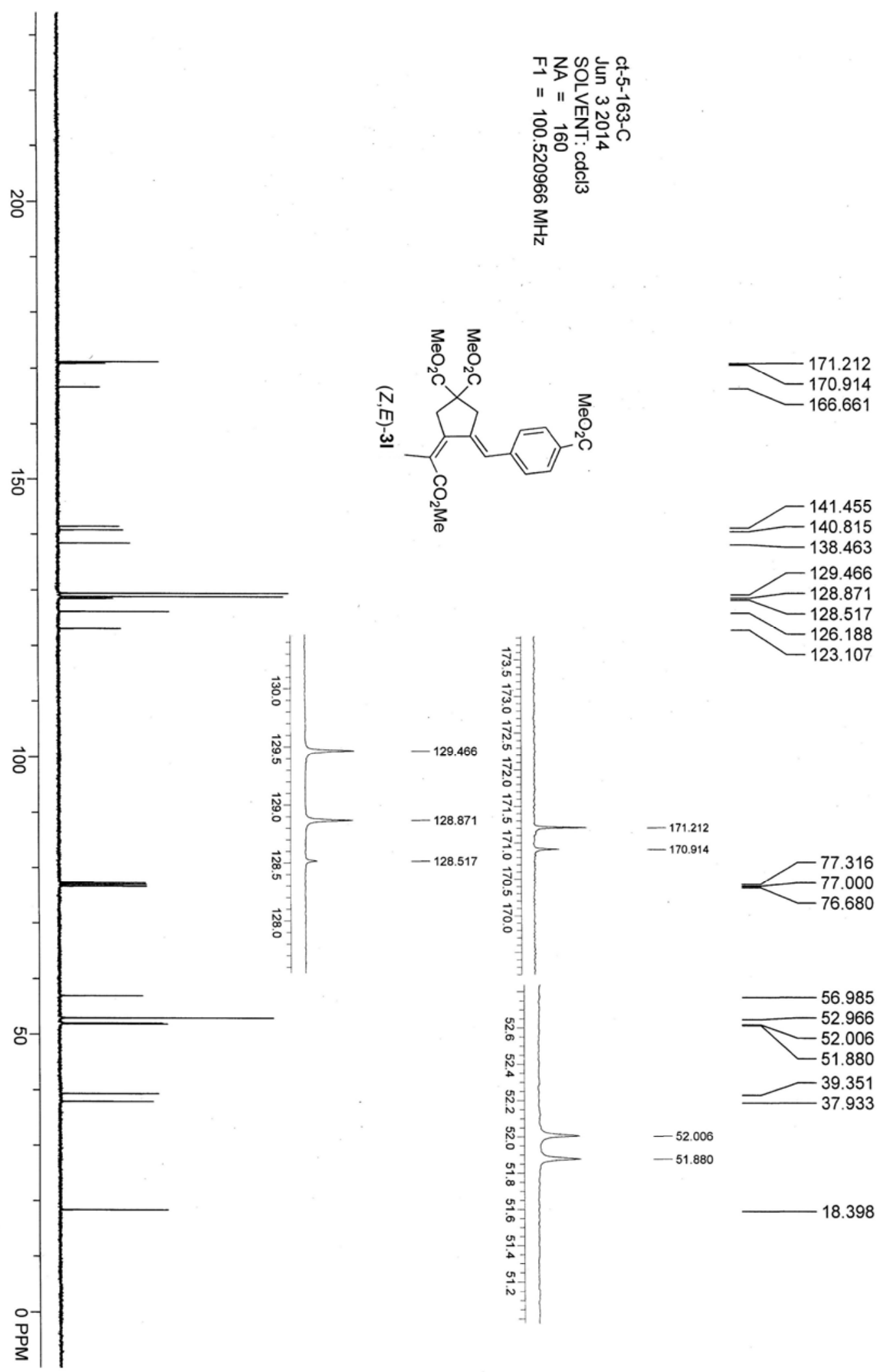

$-52.006$

$-51.880$

18.398 

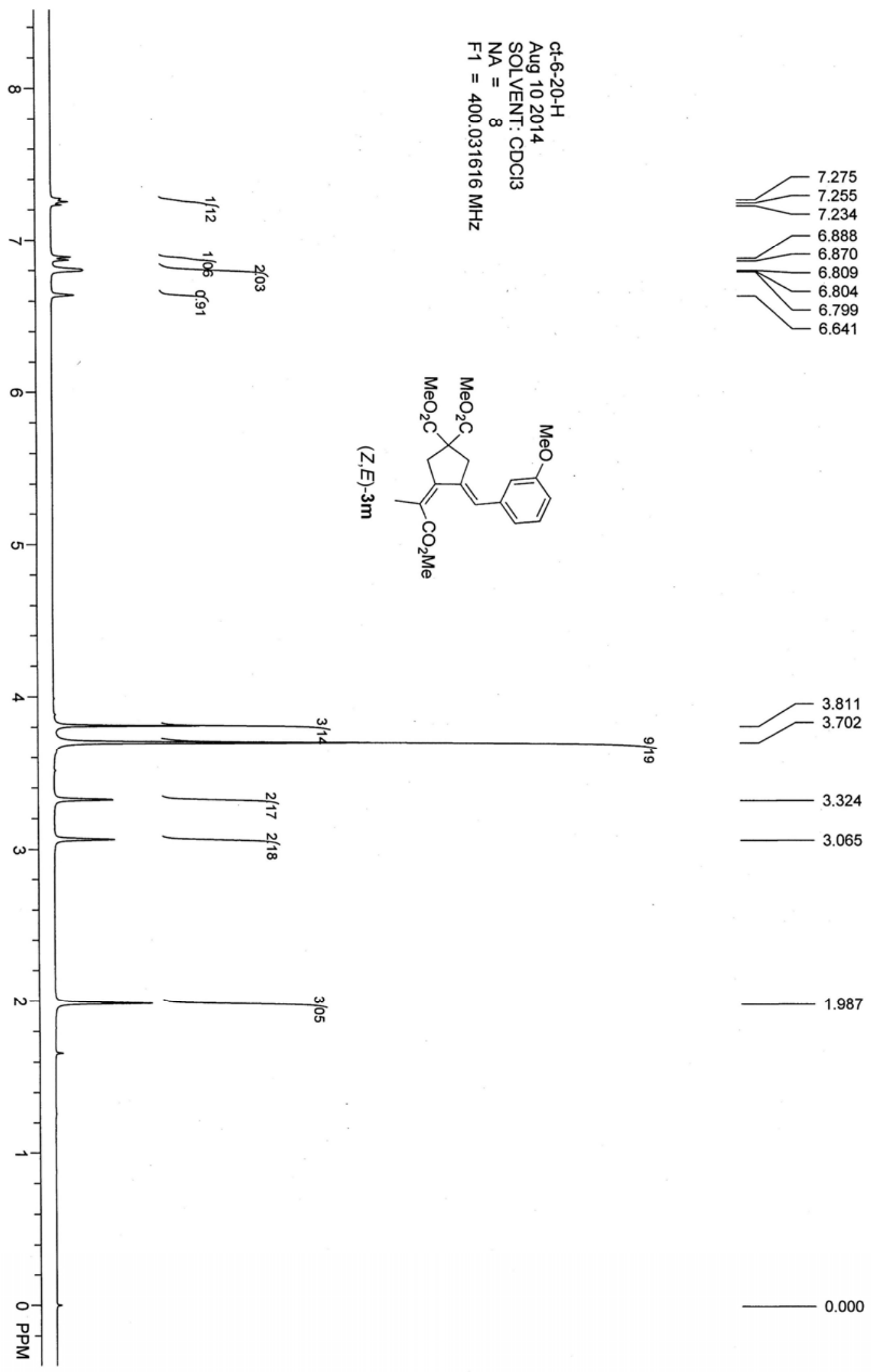

0.000 


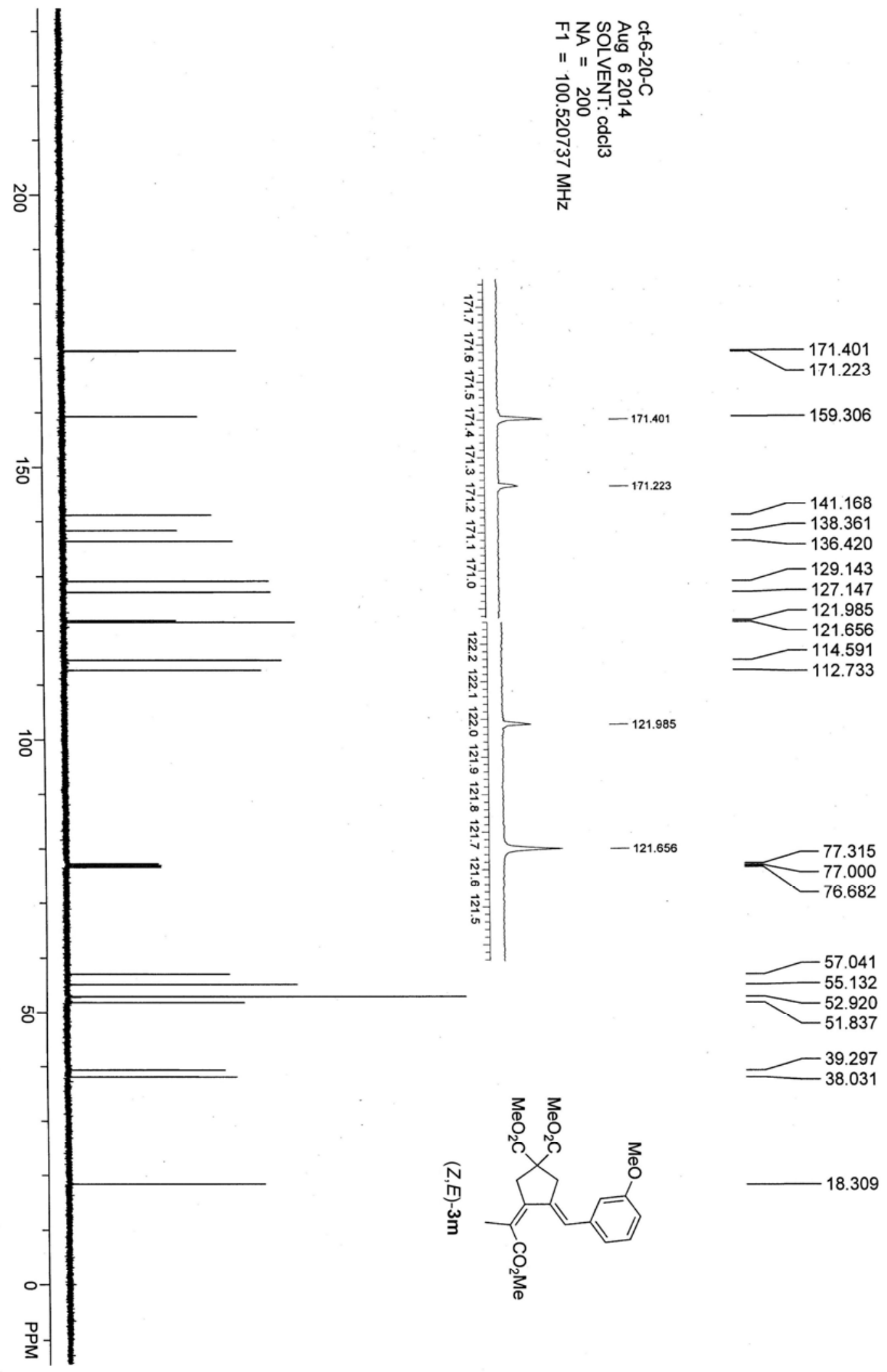



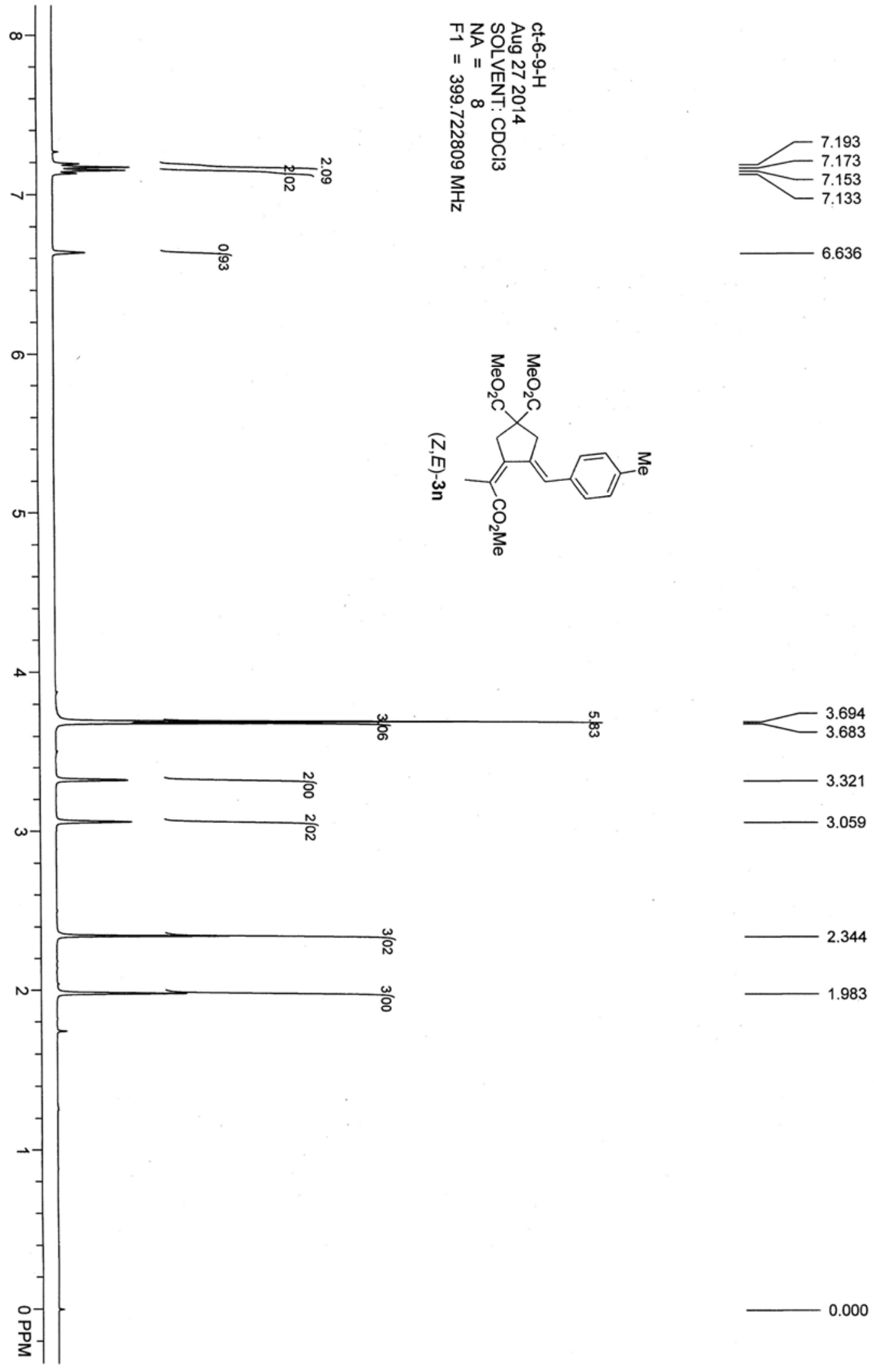

2.344

1.983 


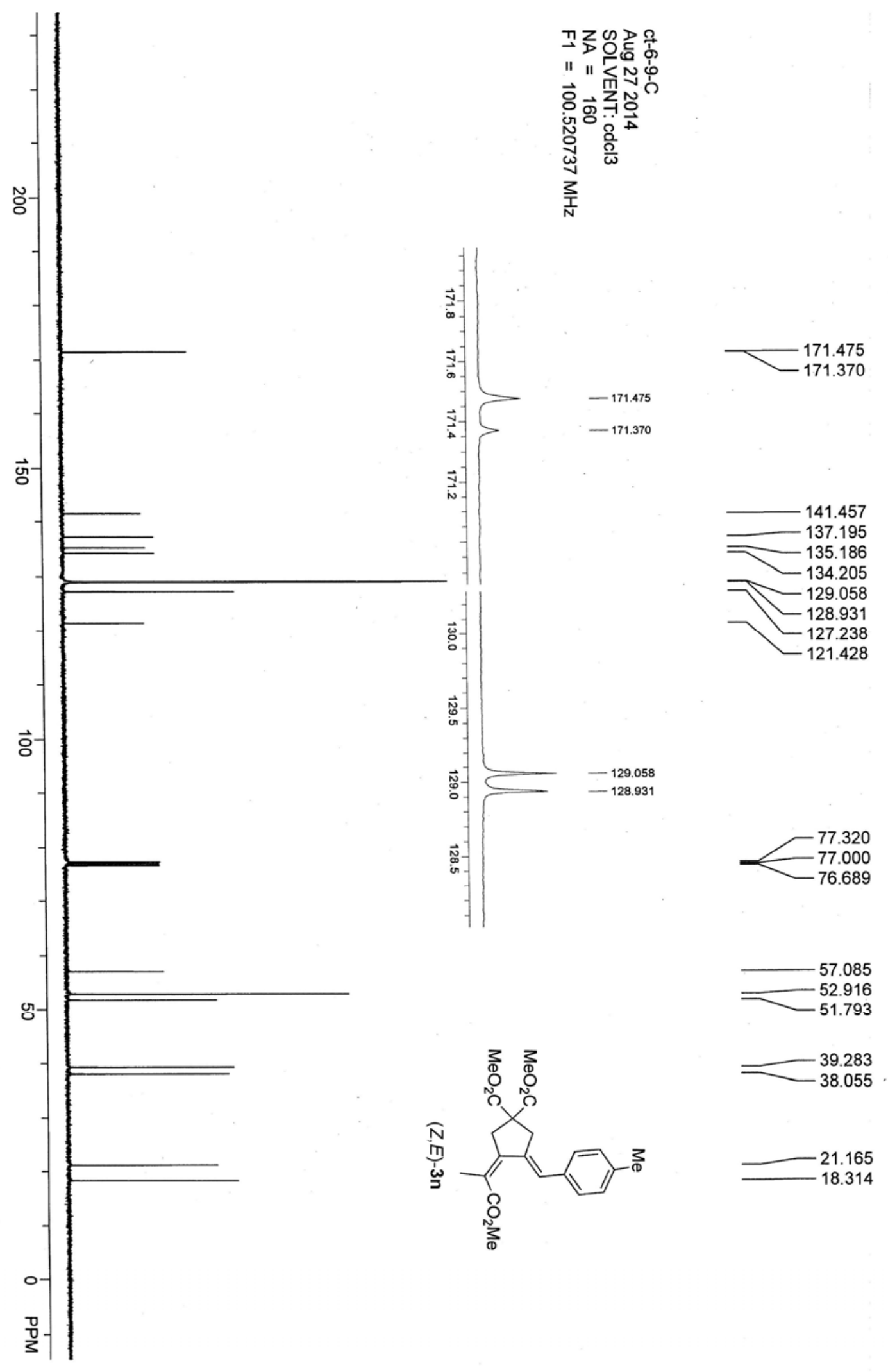



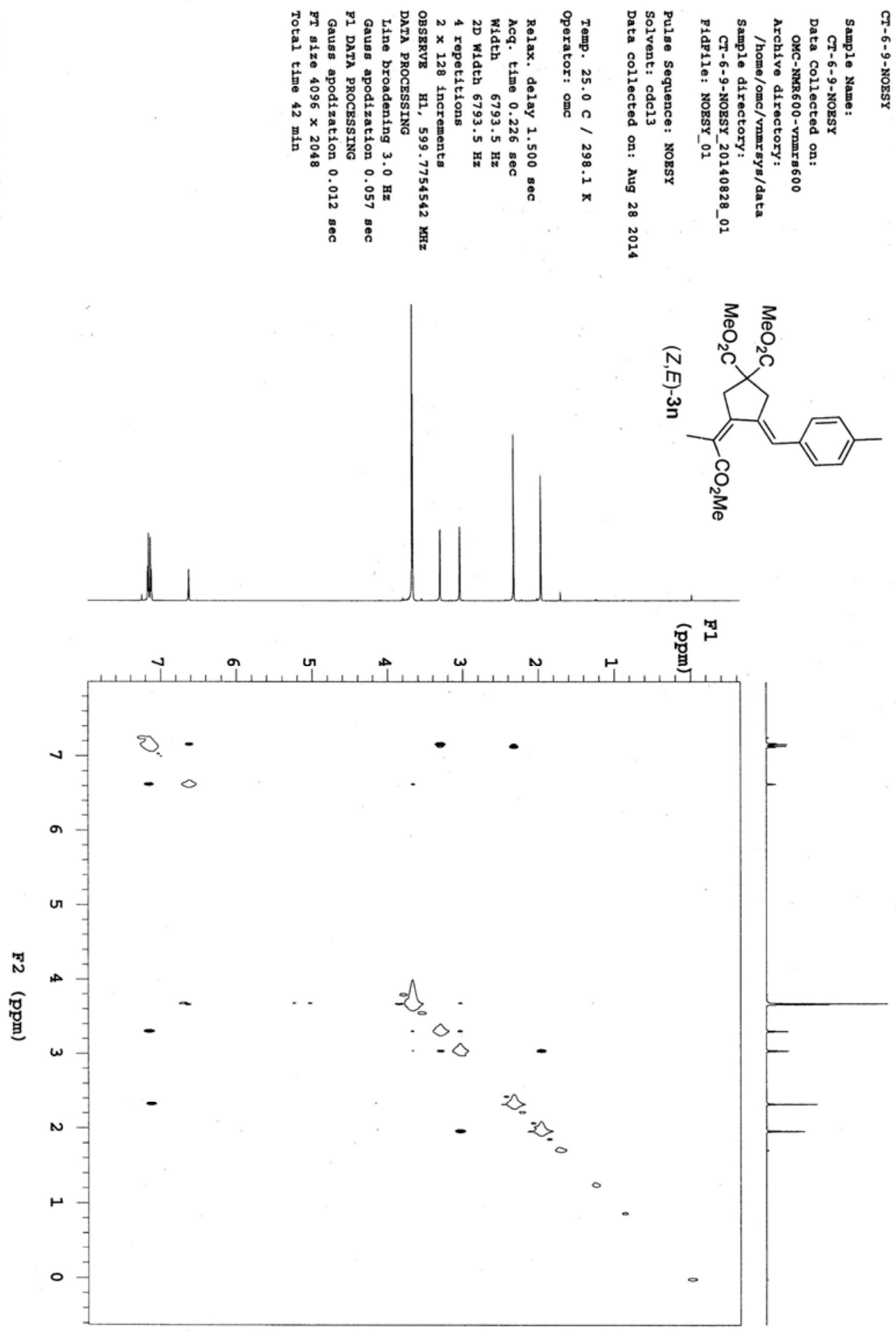

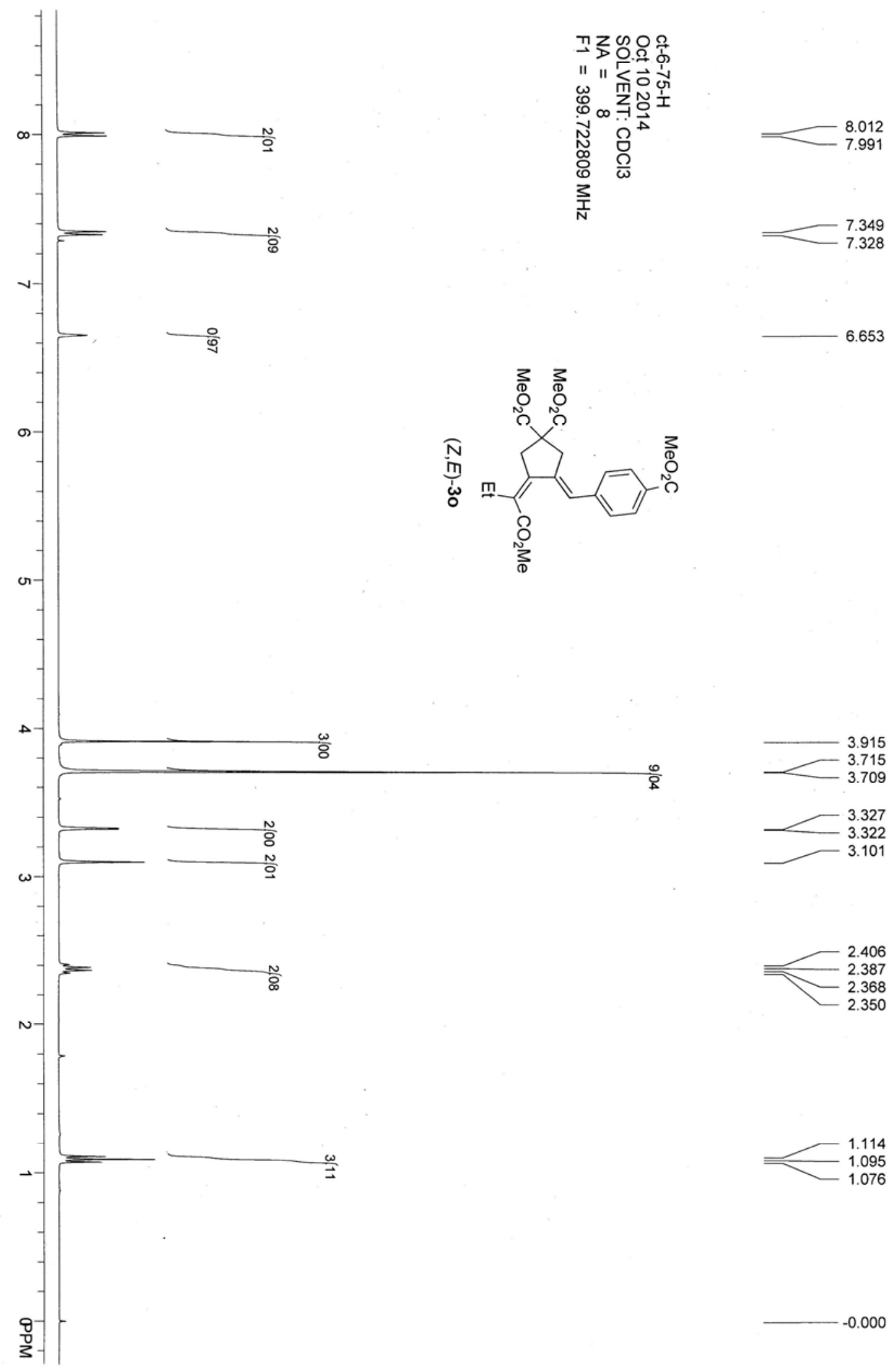


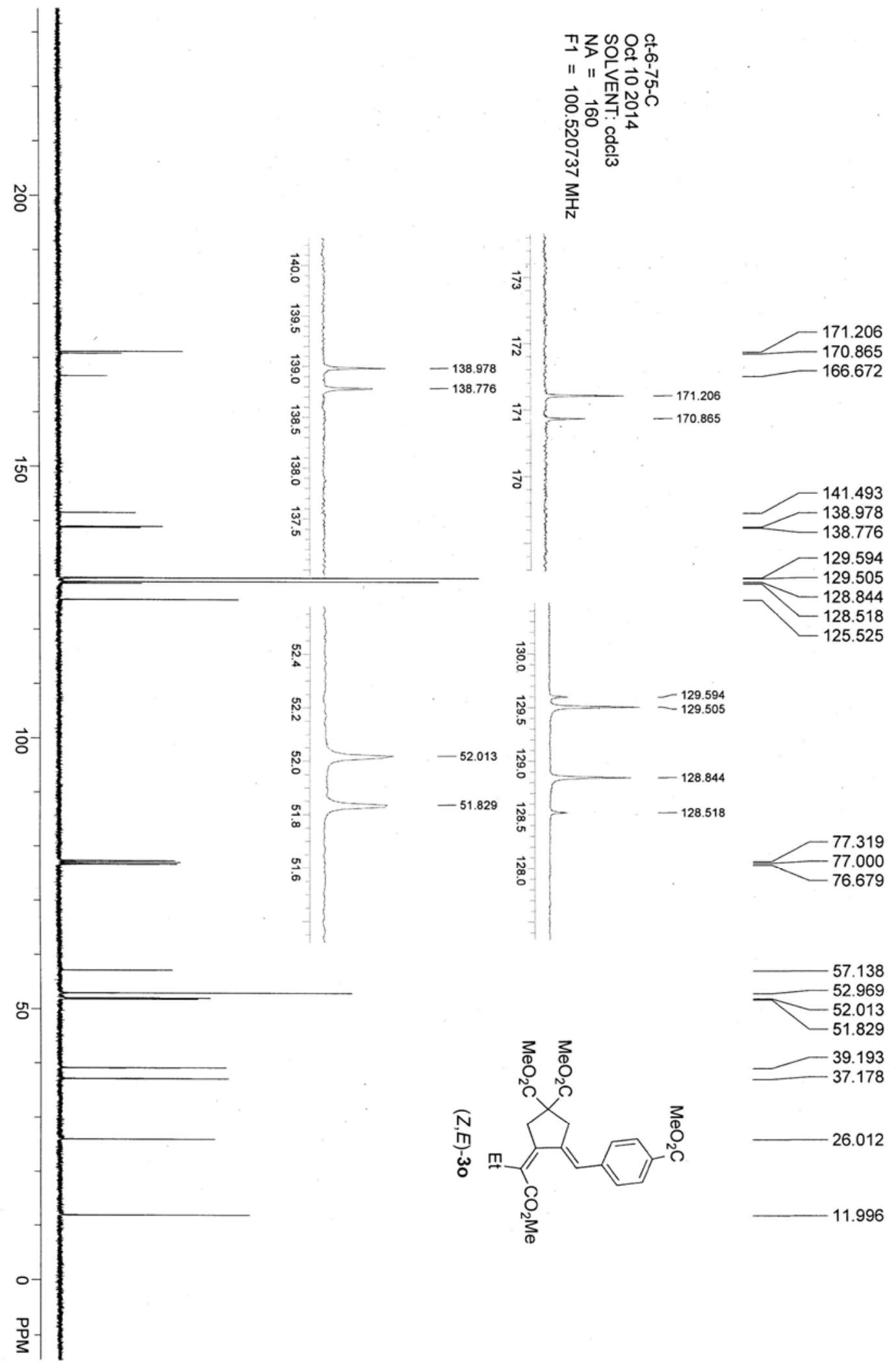



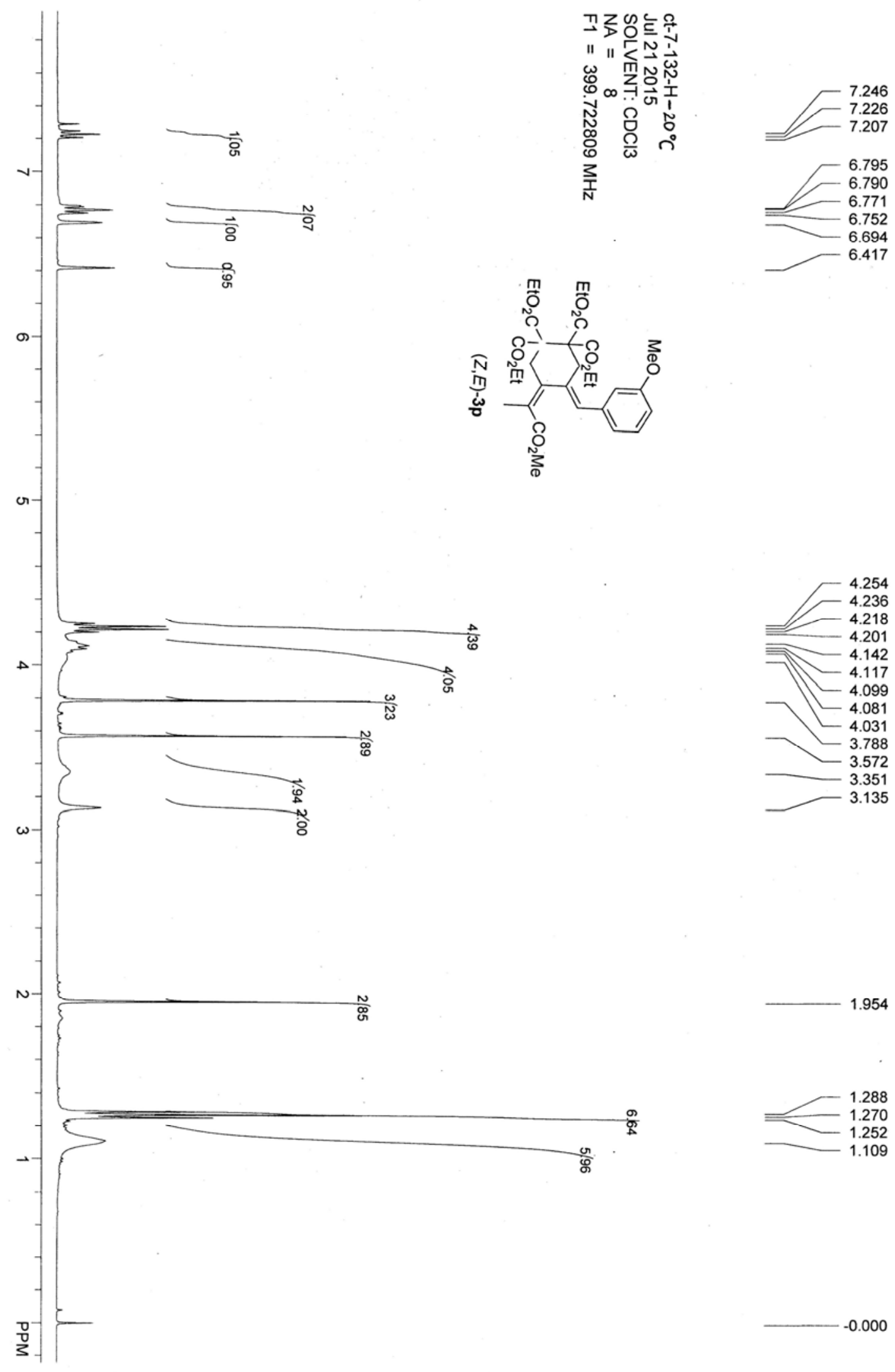

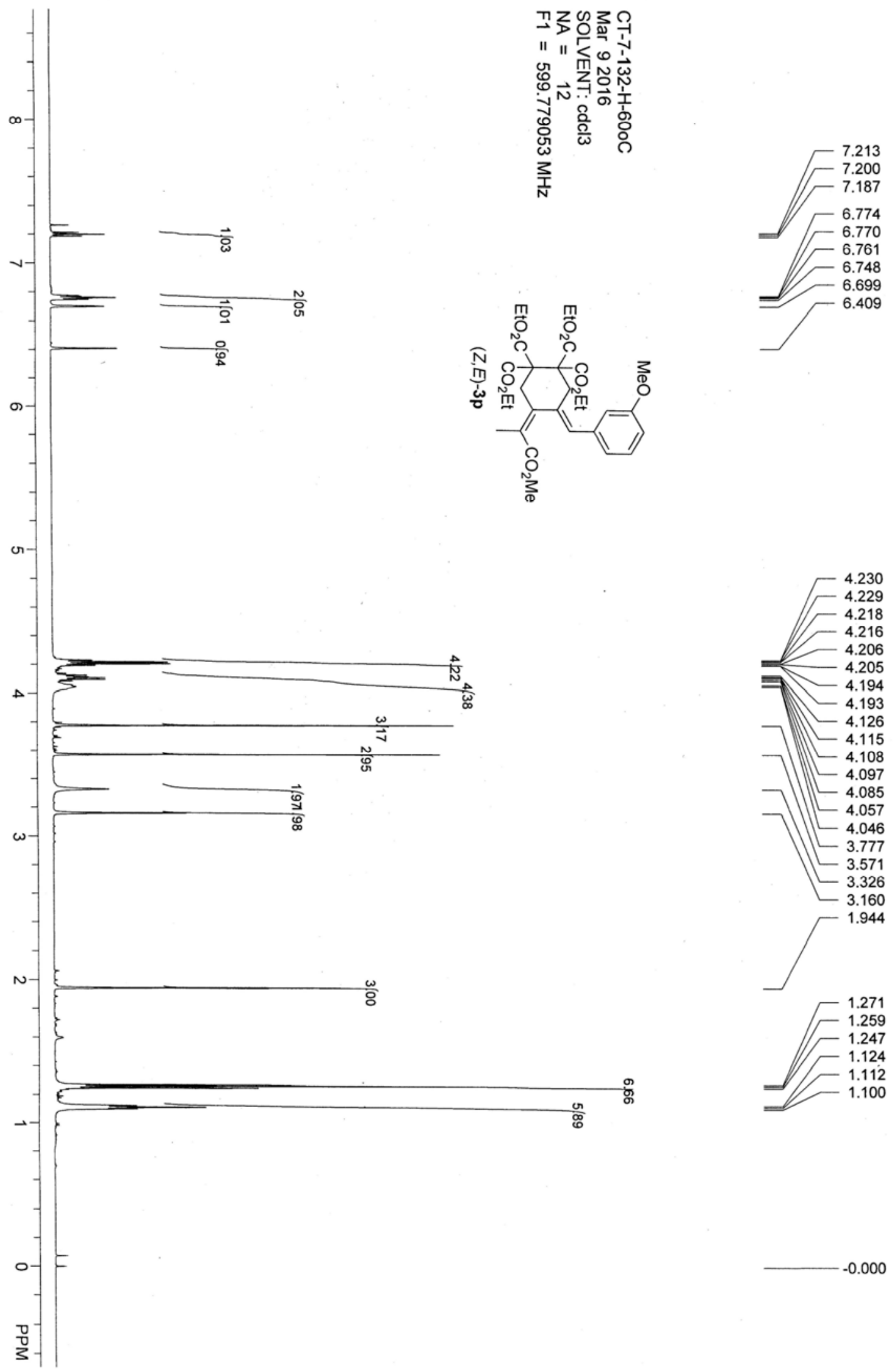


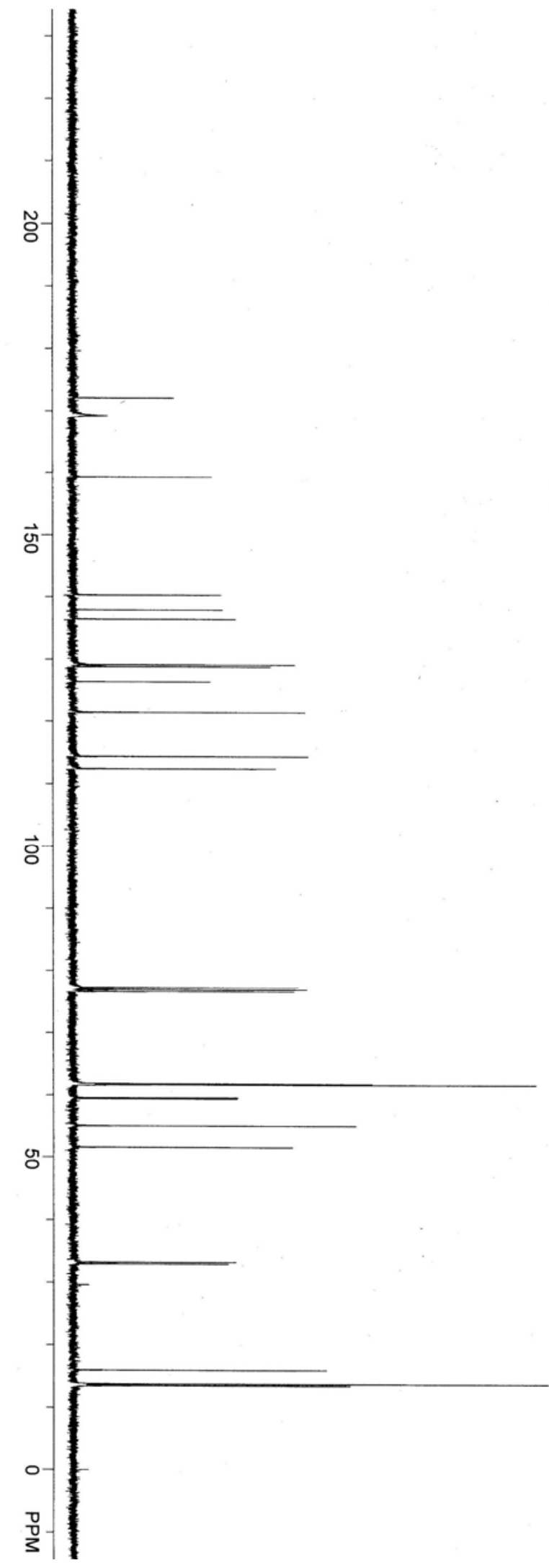

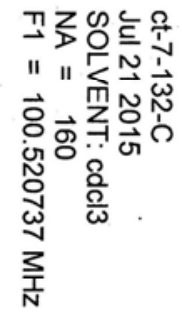
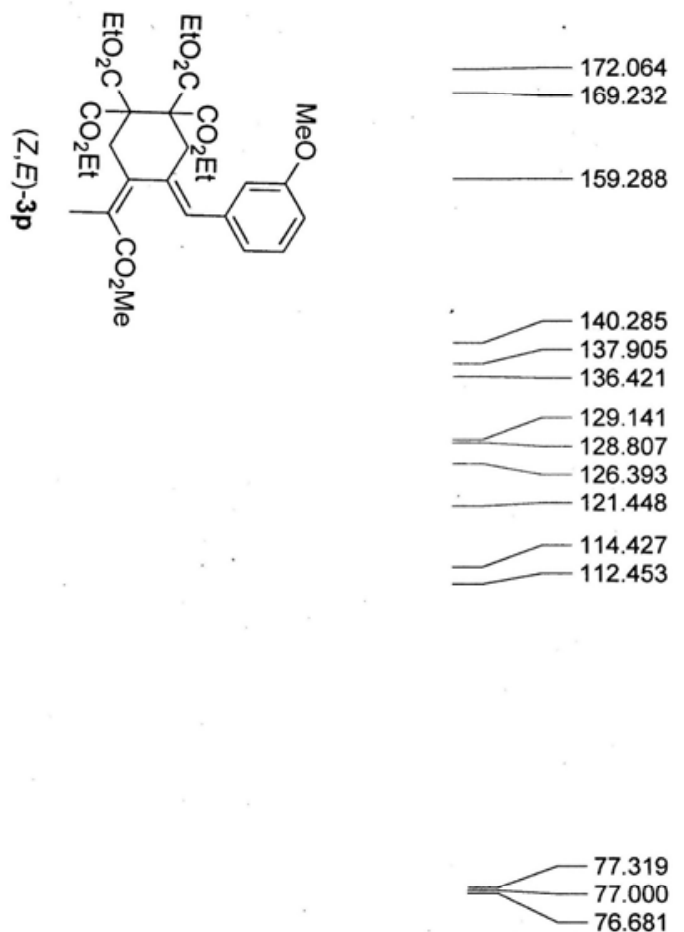

76.681

61.818

61.674

59.594

59.412

55.093

51.559

33.258

15.947

13.723

13.465

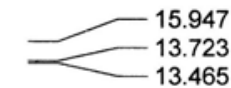



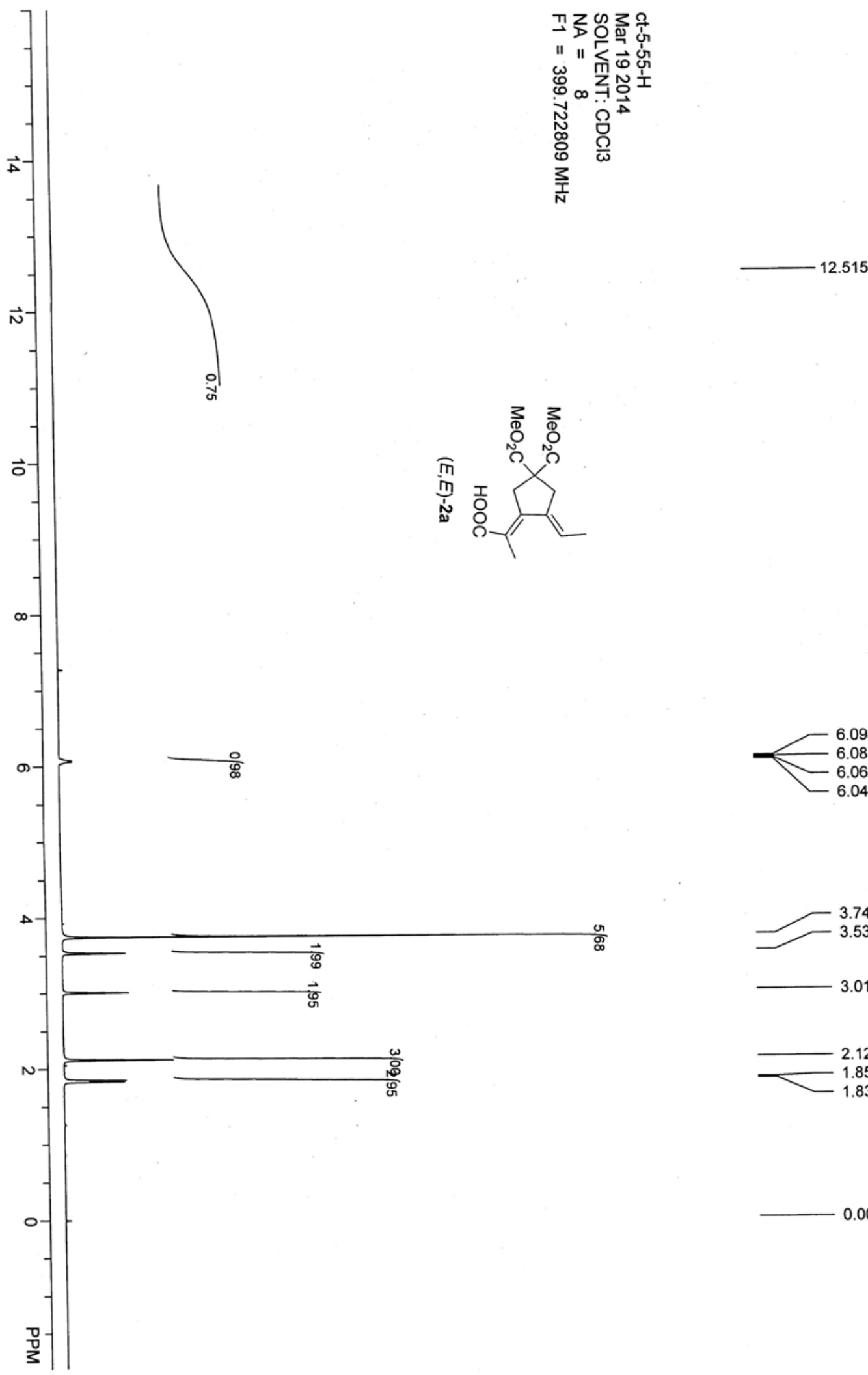

.515
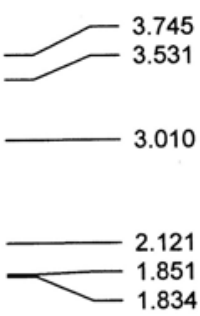

0.000 

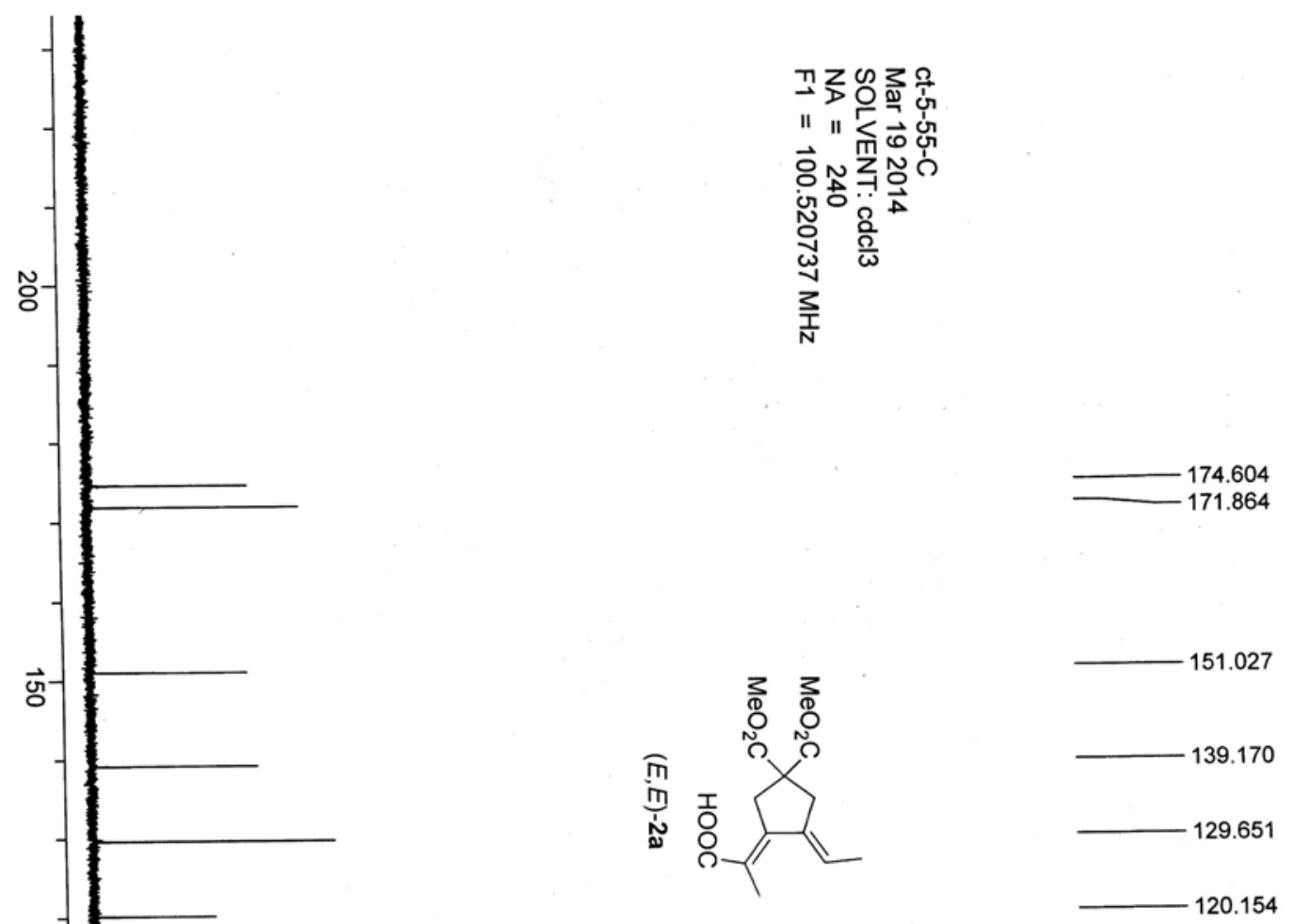

어

앙-

जु

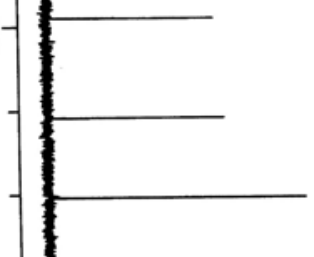

-
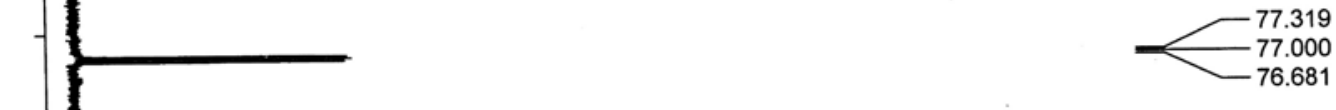

76.681
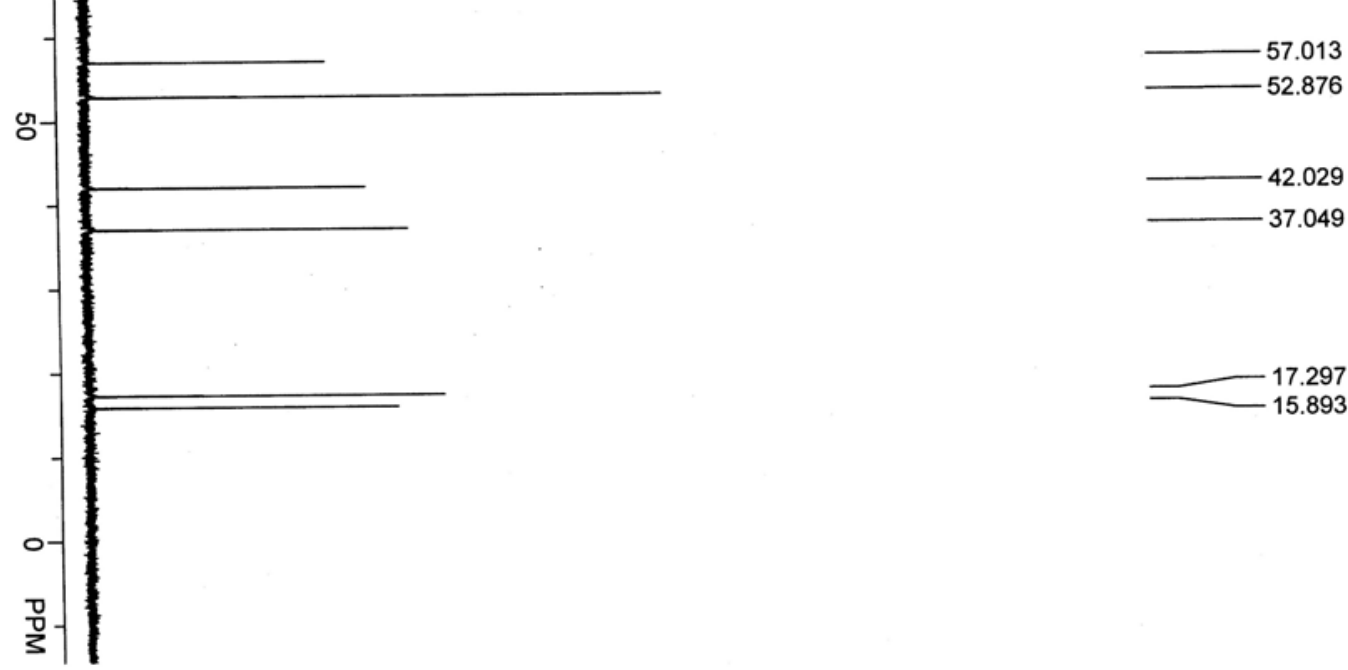

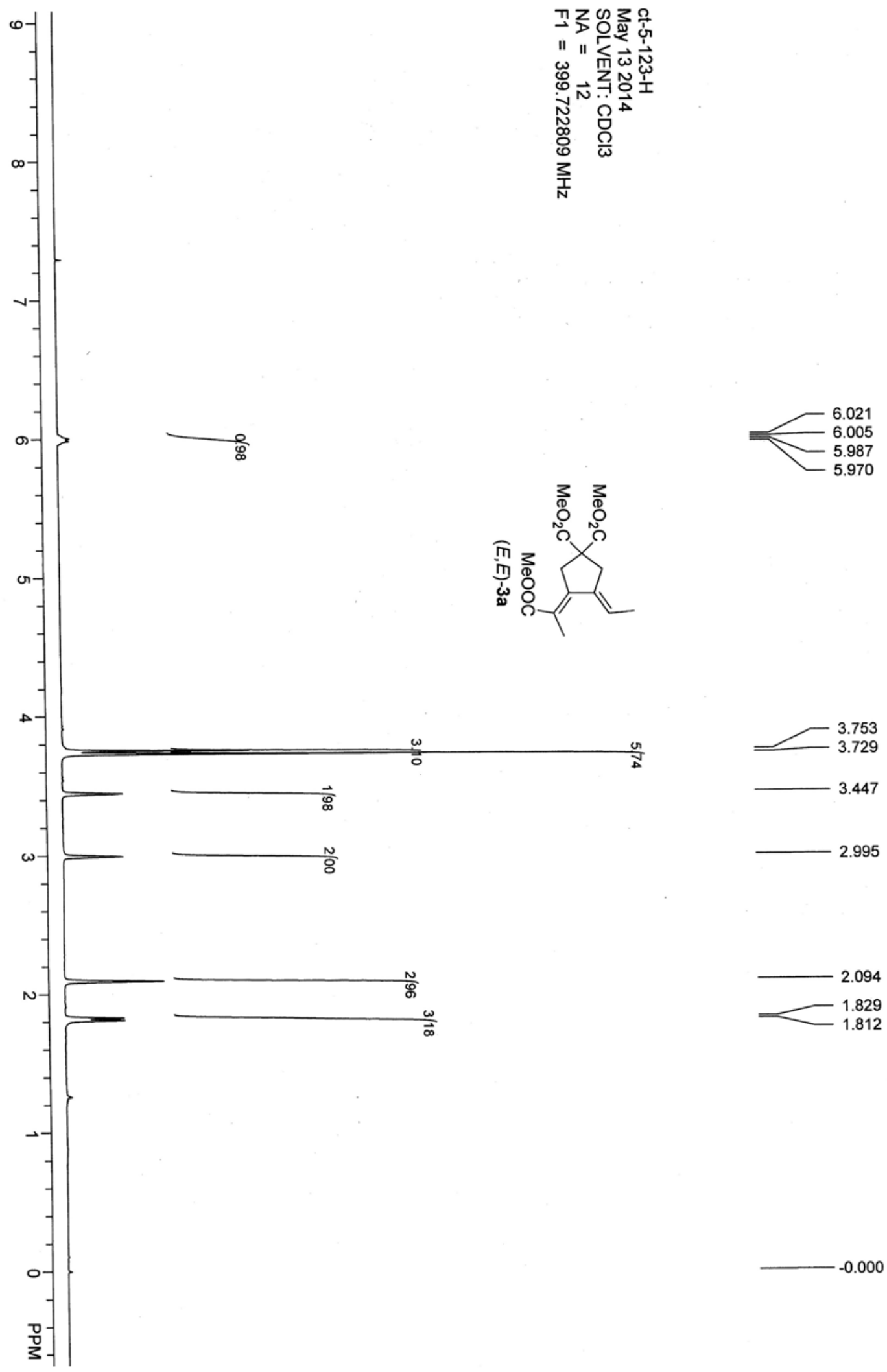
$-0.000$ 

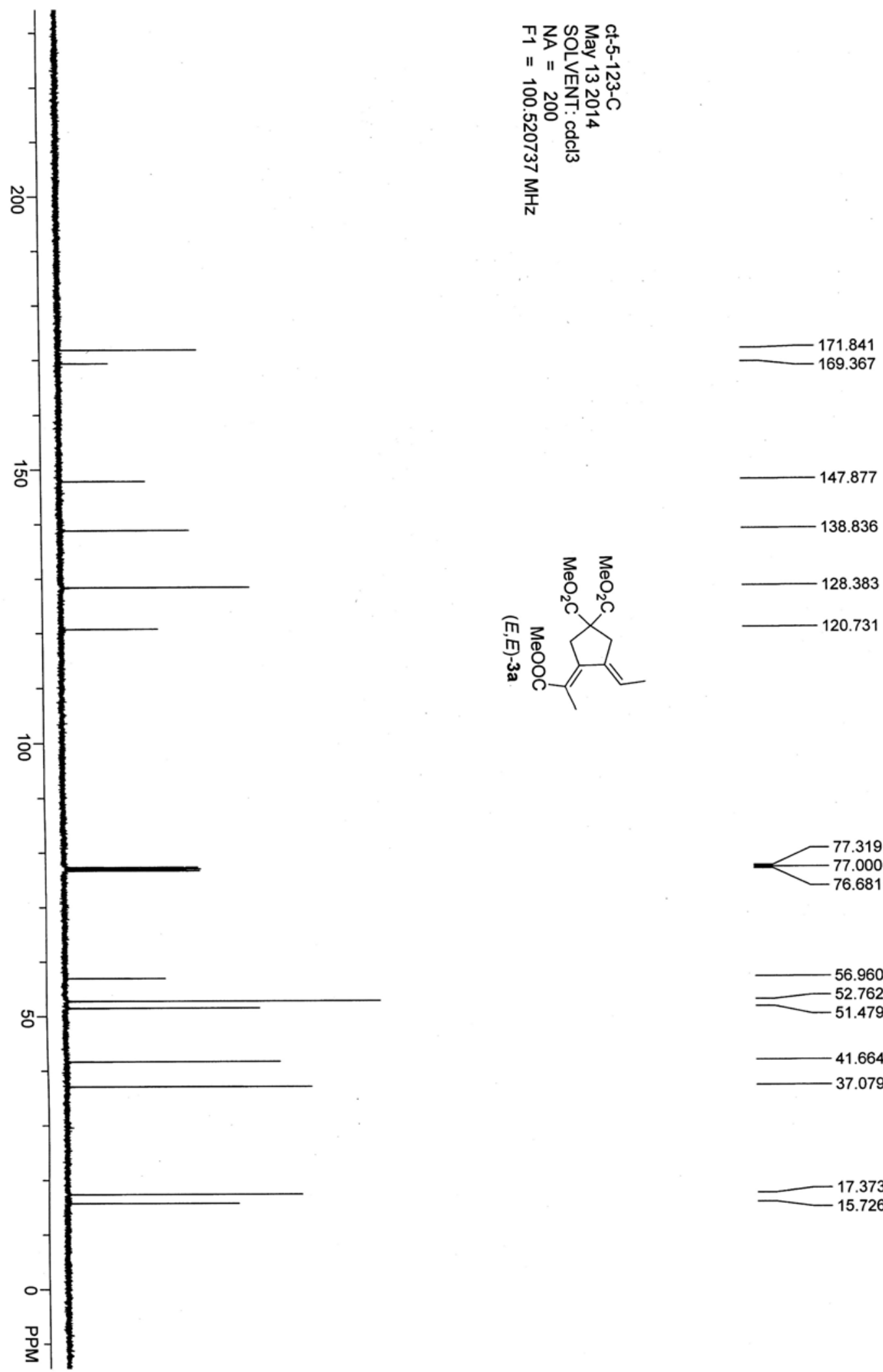

51.479
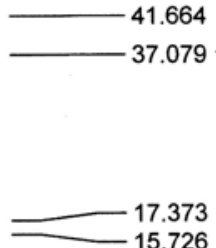

15.726 

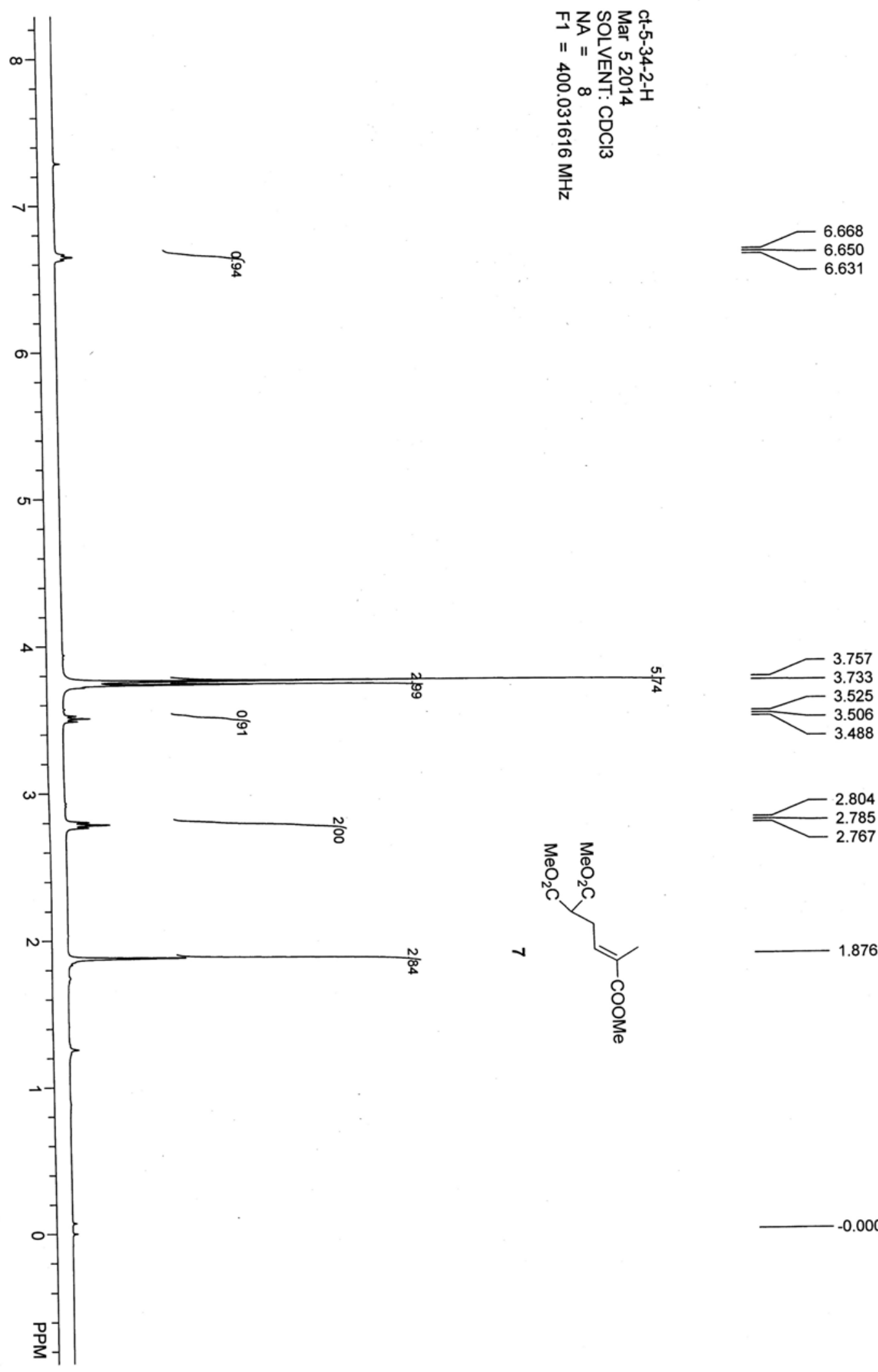

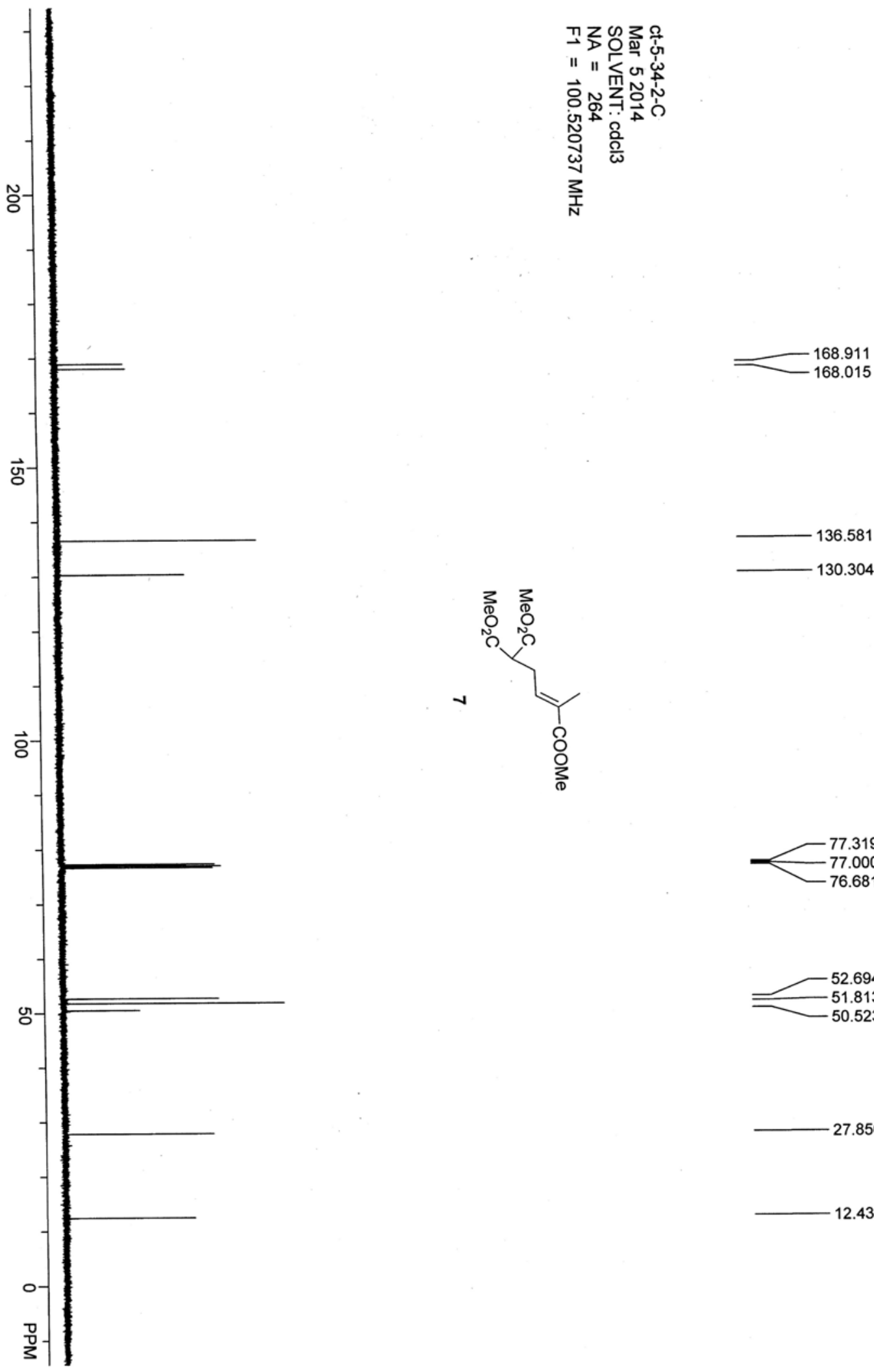

168.015
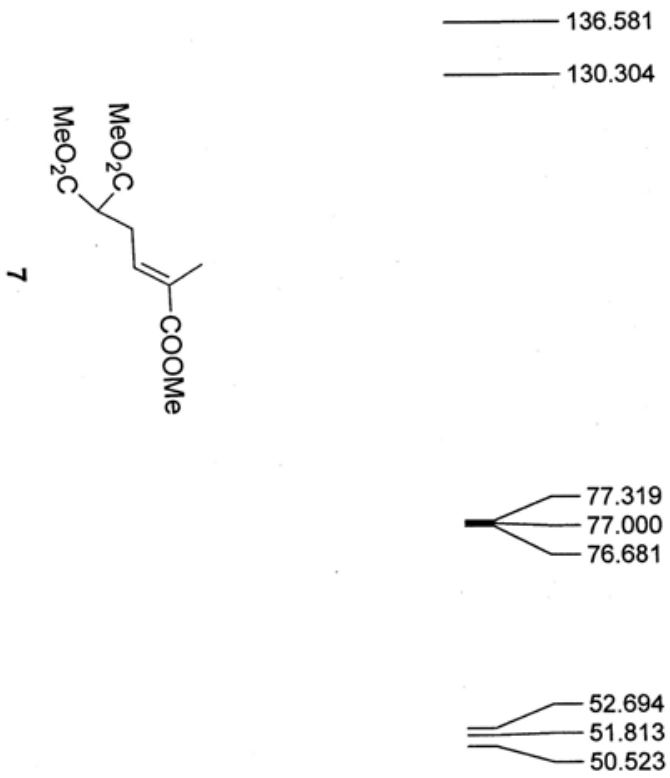

27.856

12.439 

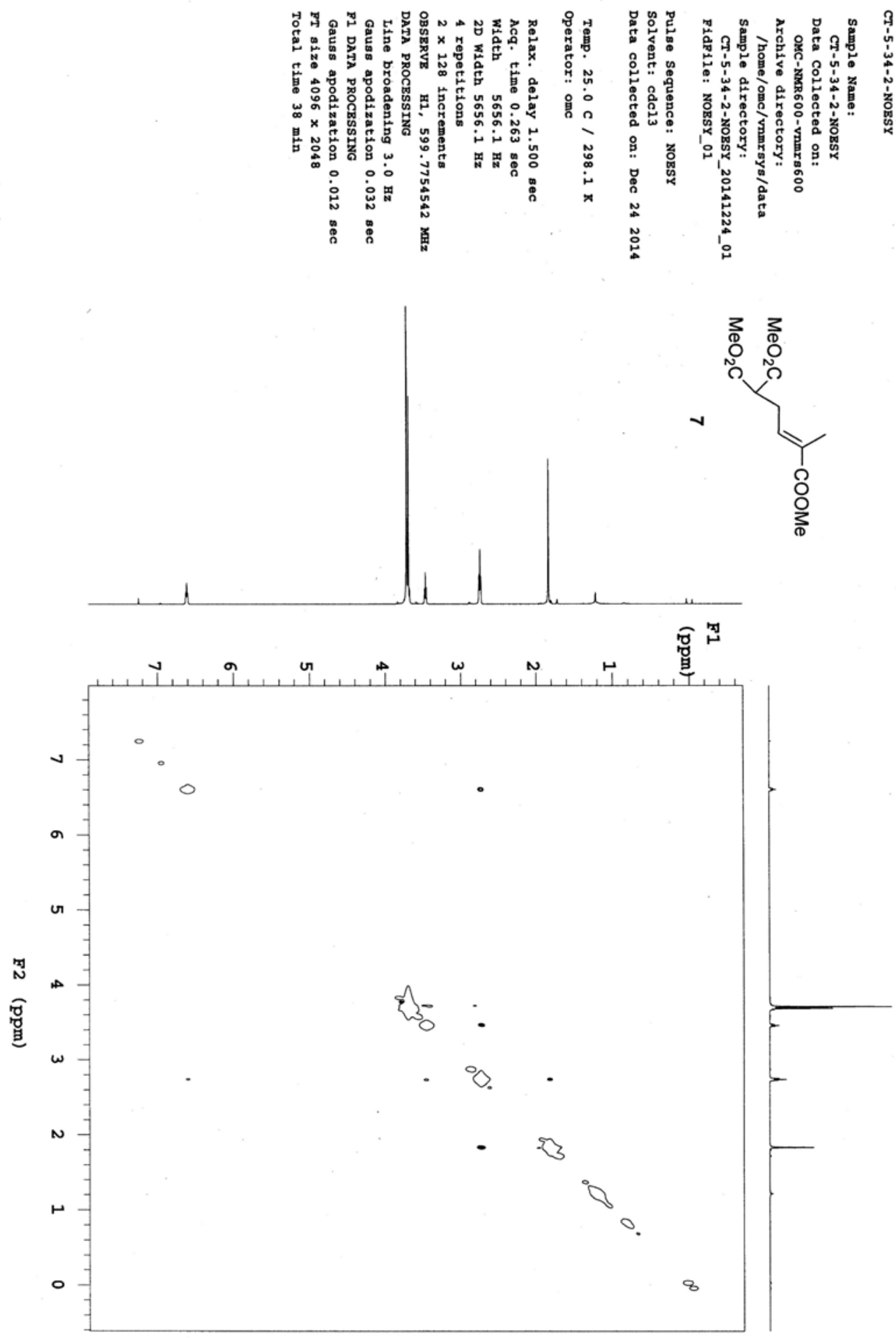


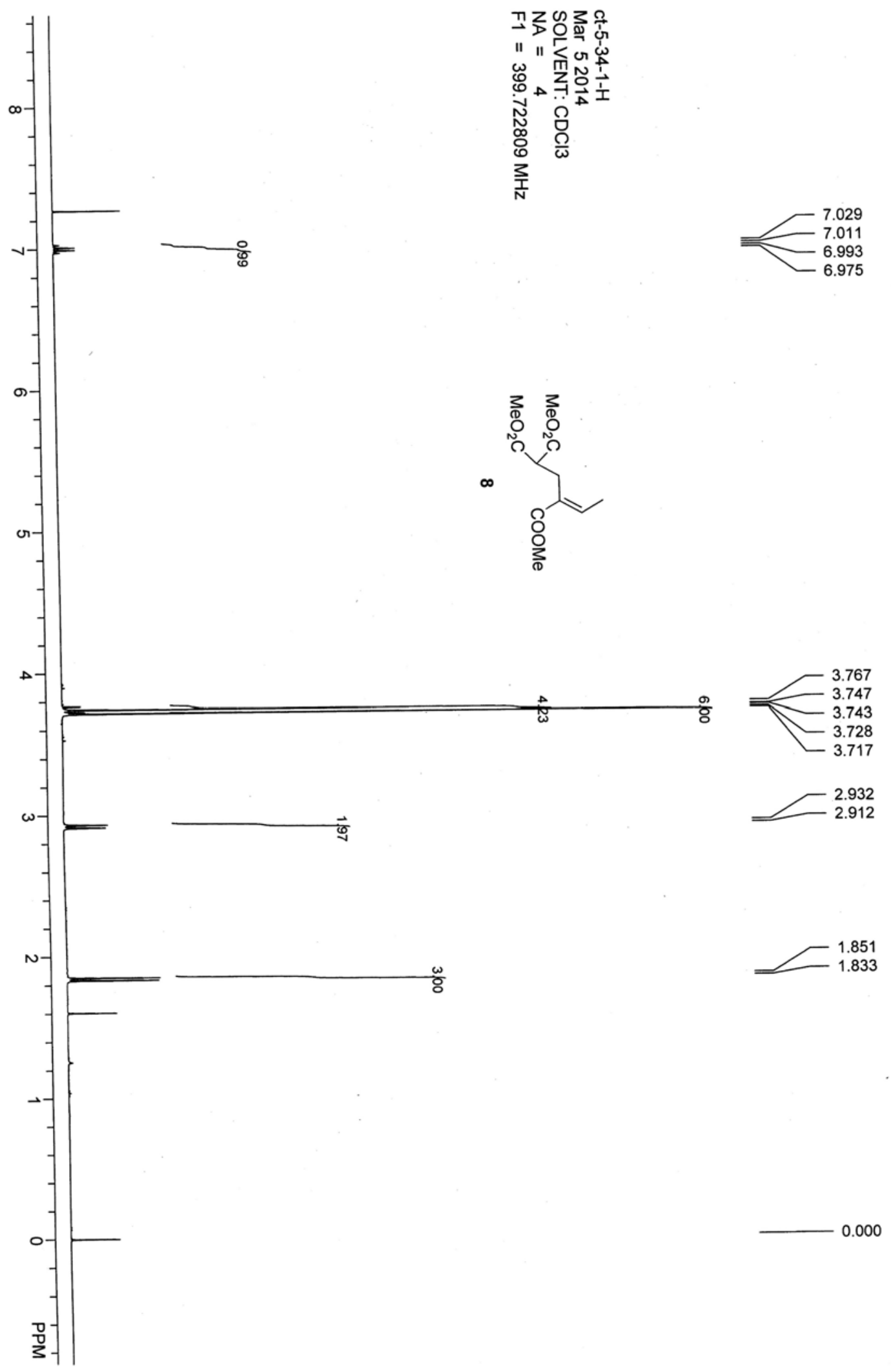



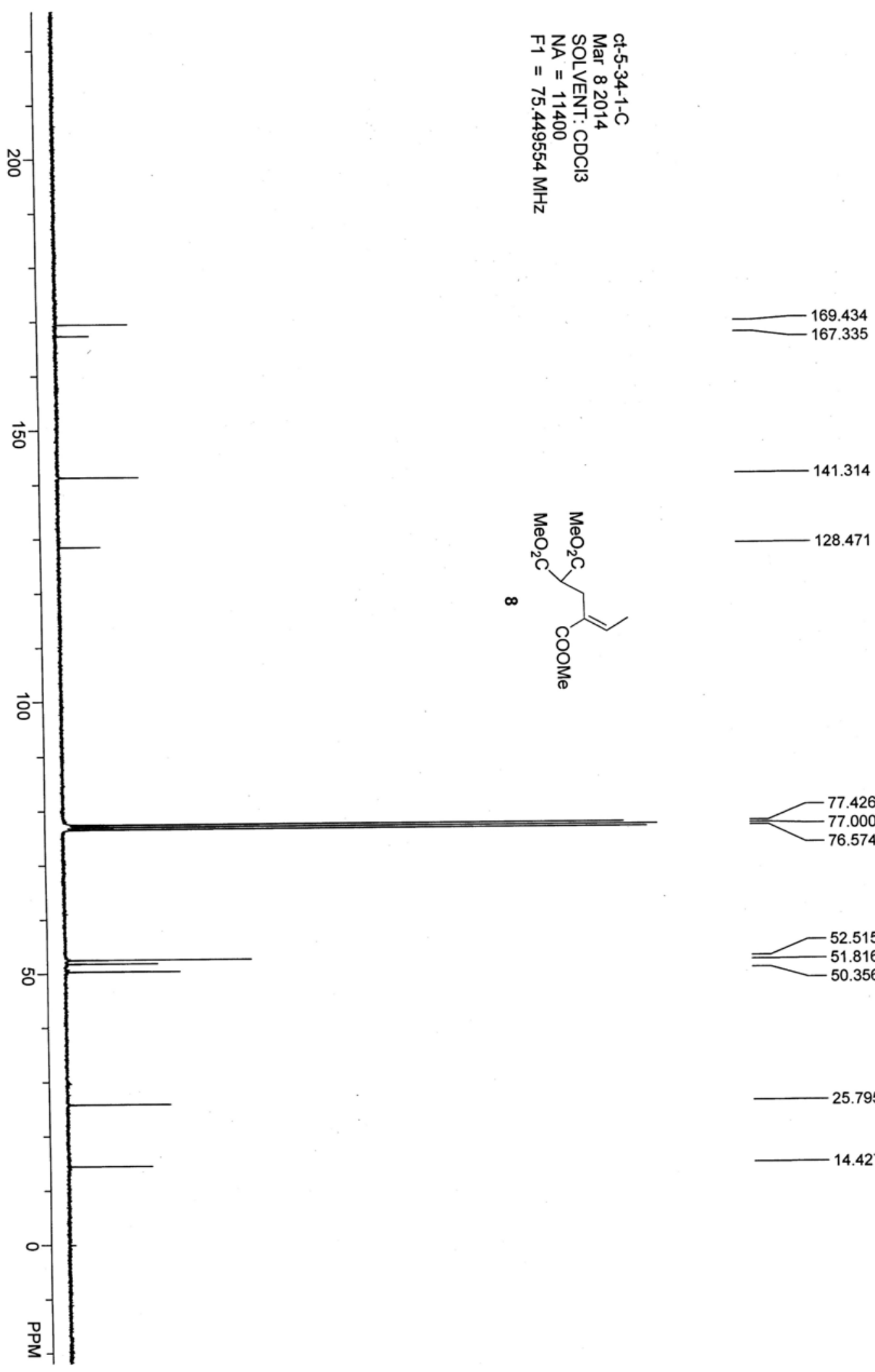

128.471
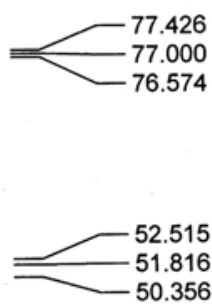

$-25.795$

14.427 

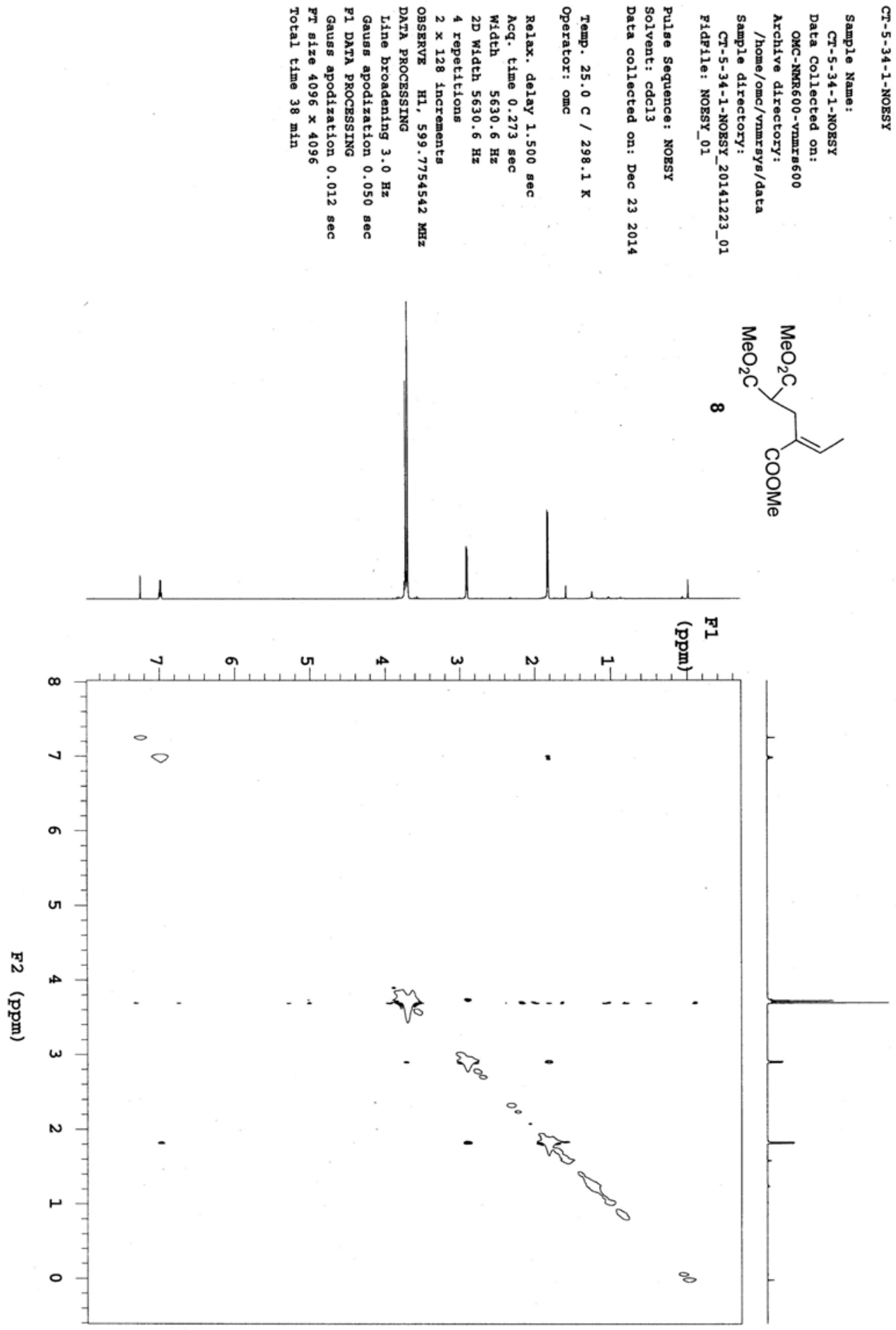

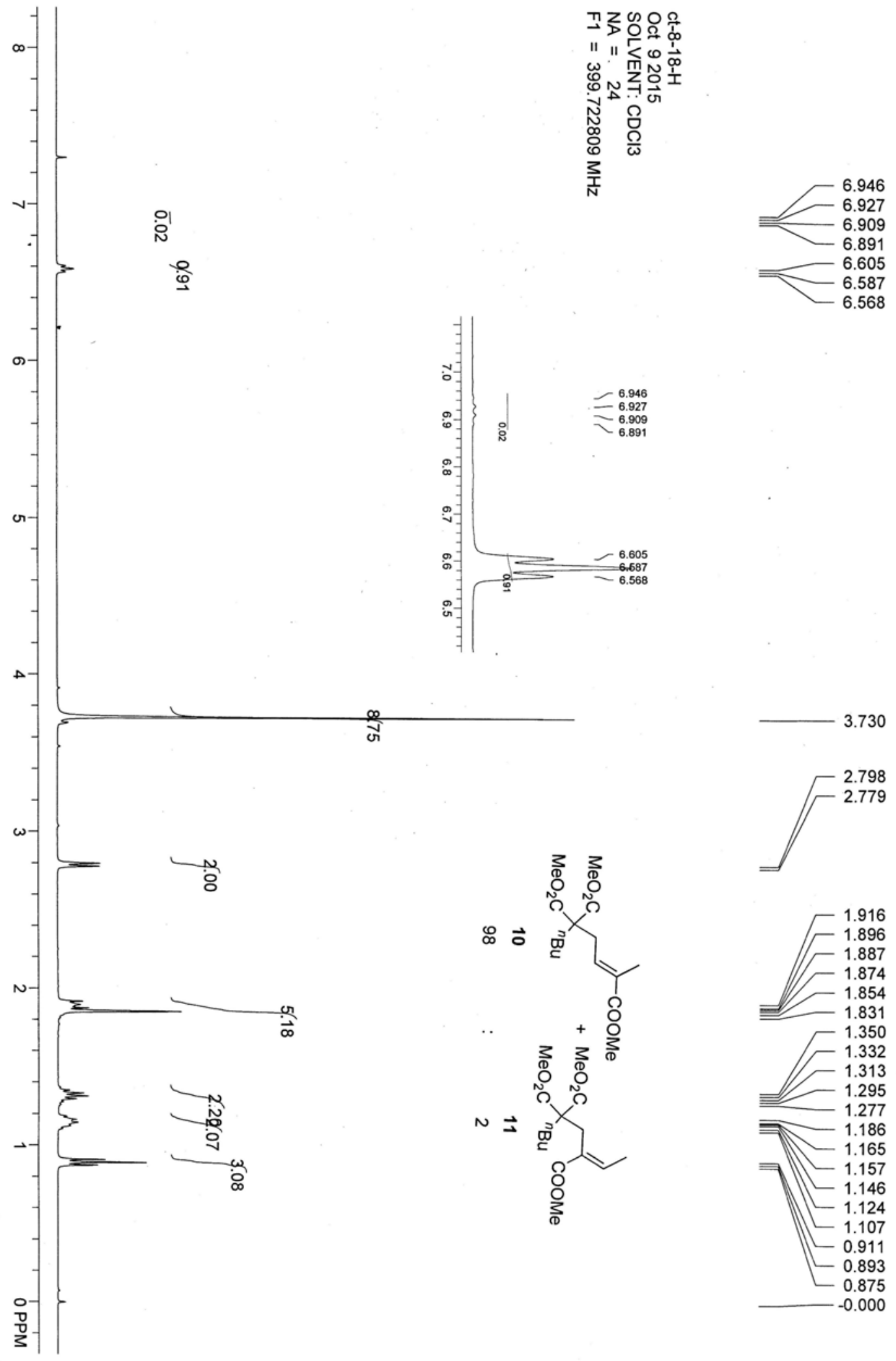

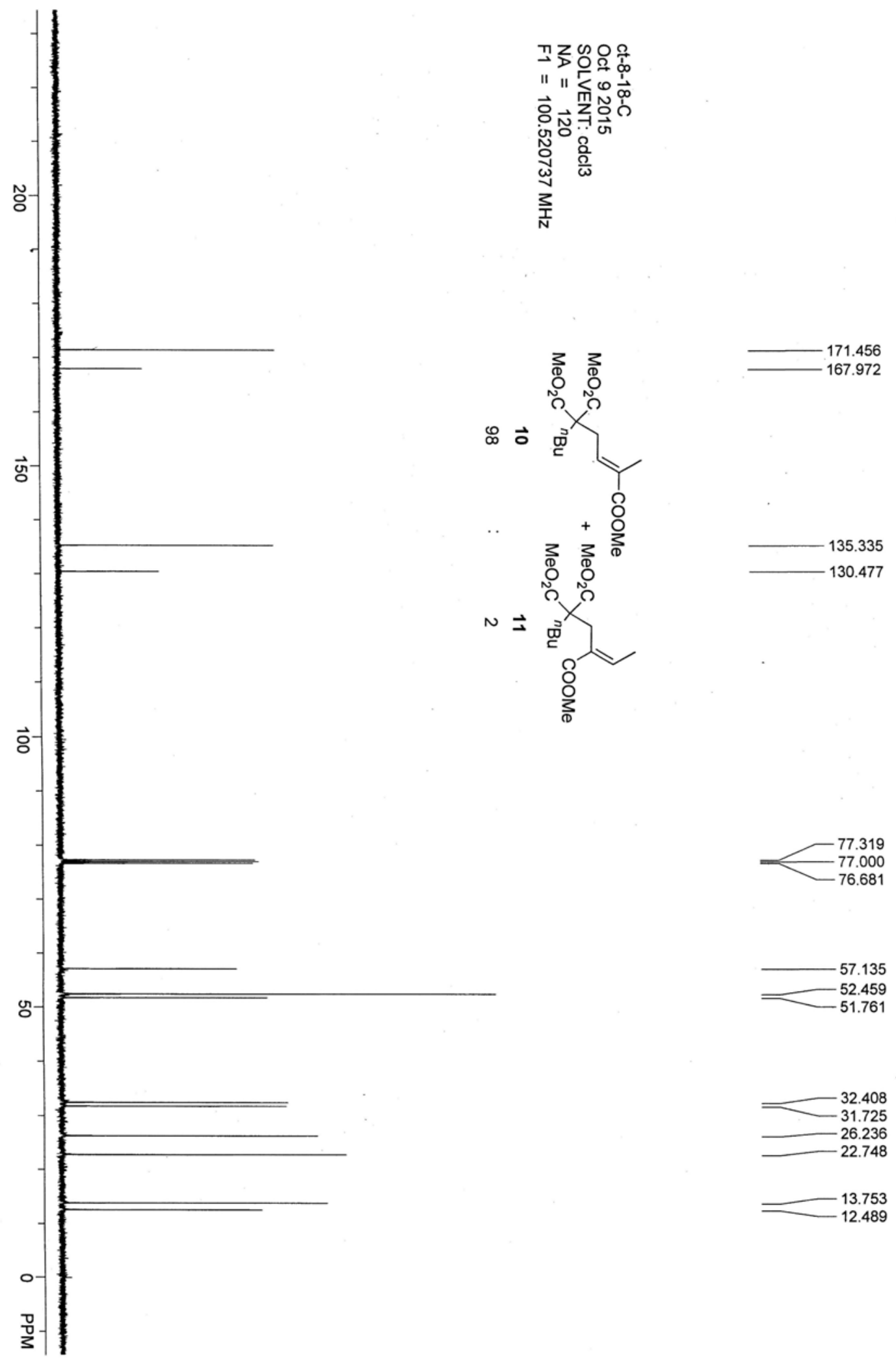

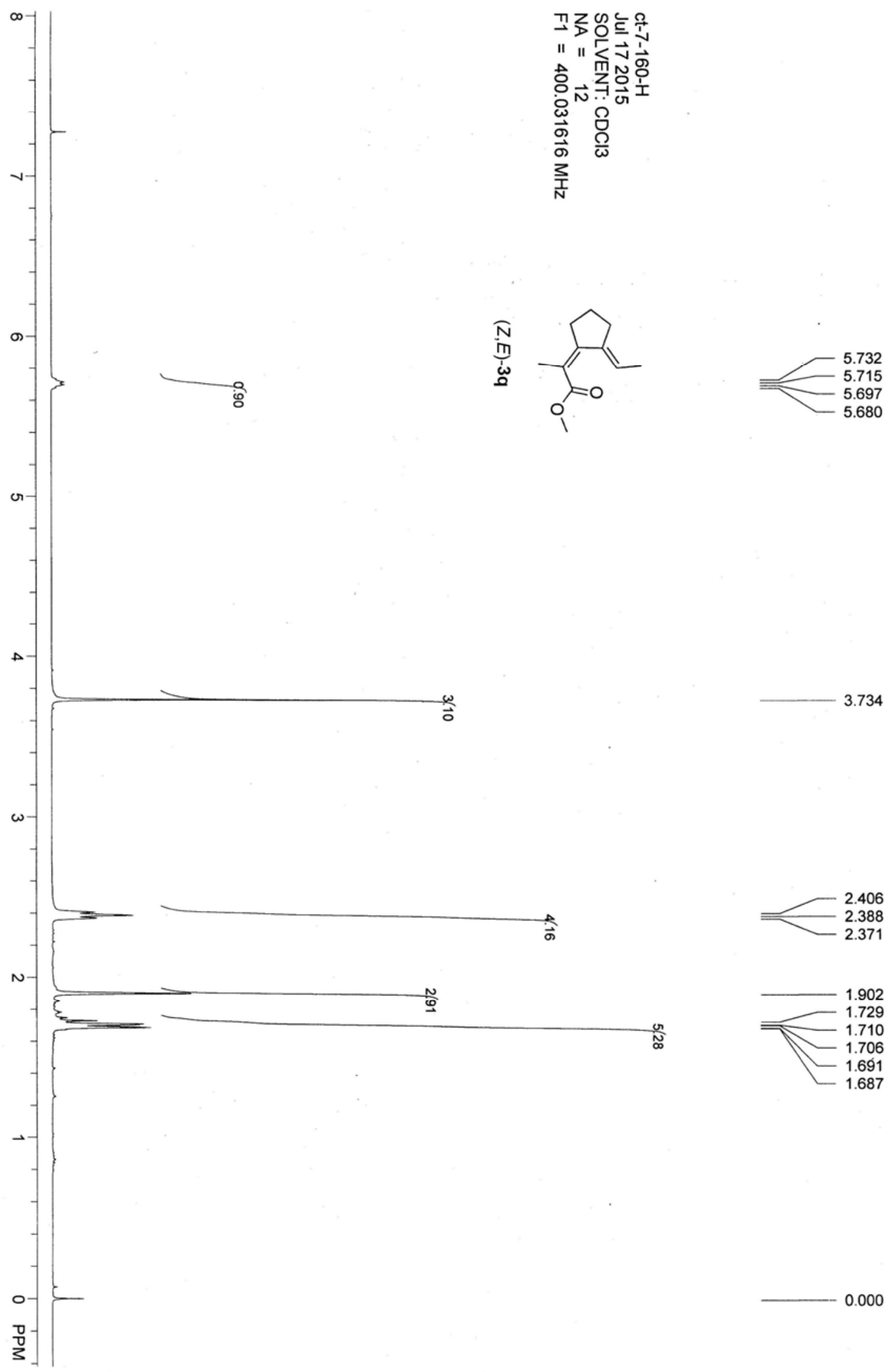

3.734

2.406

2.388

2.371

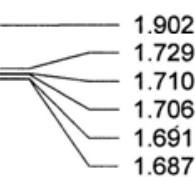

0.000 


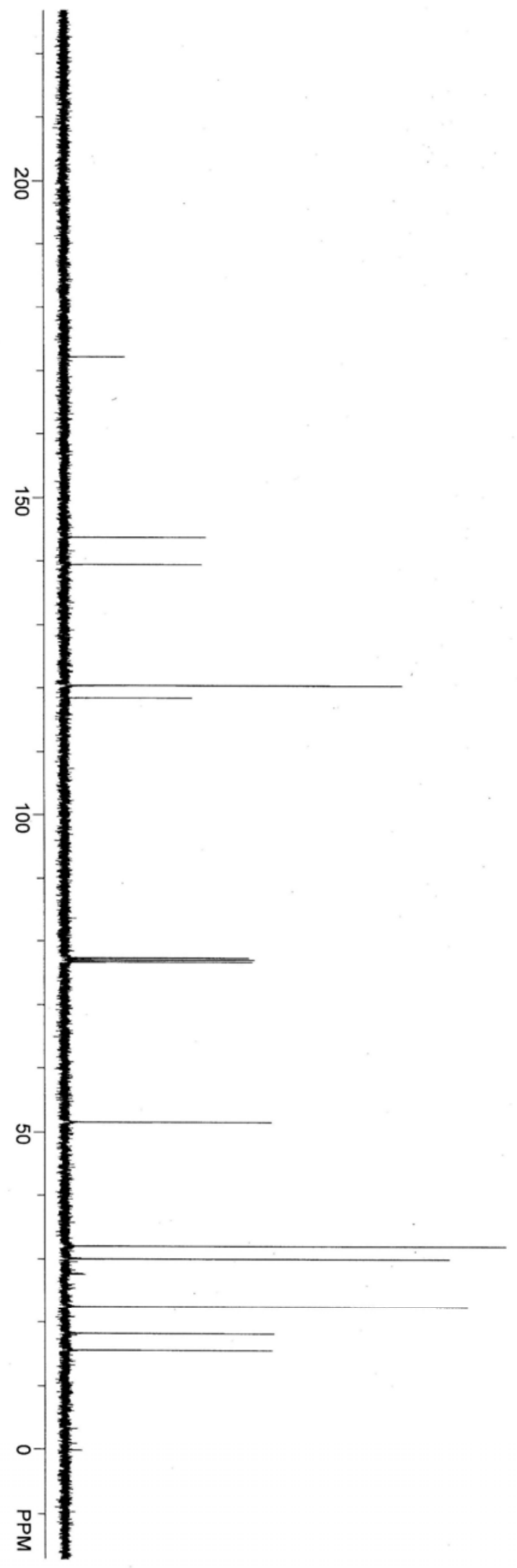

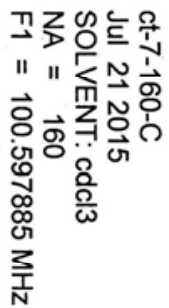

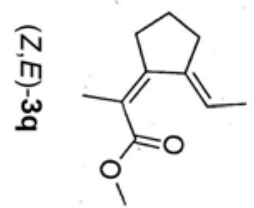
$-172.237$

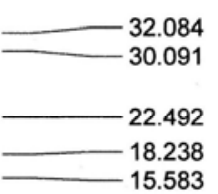



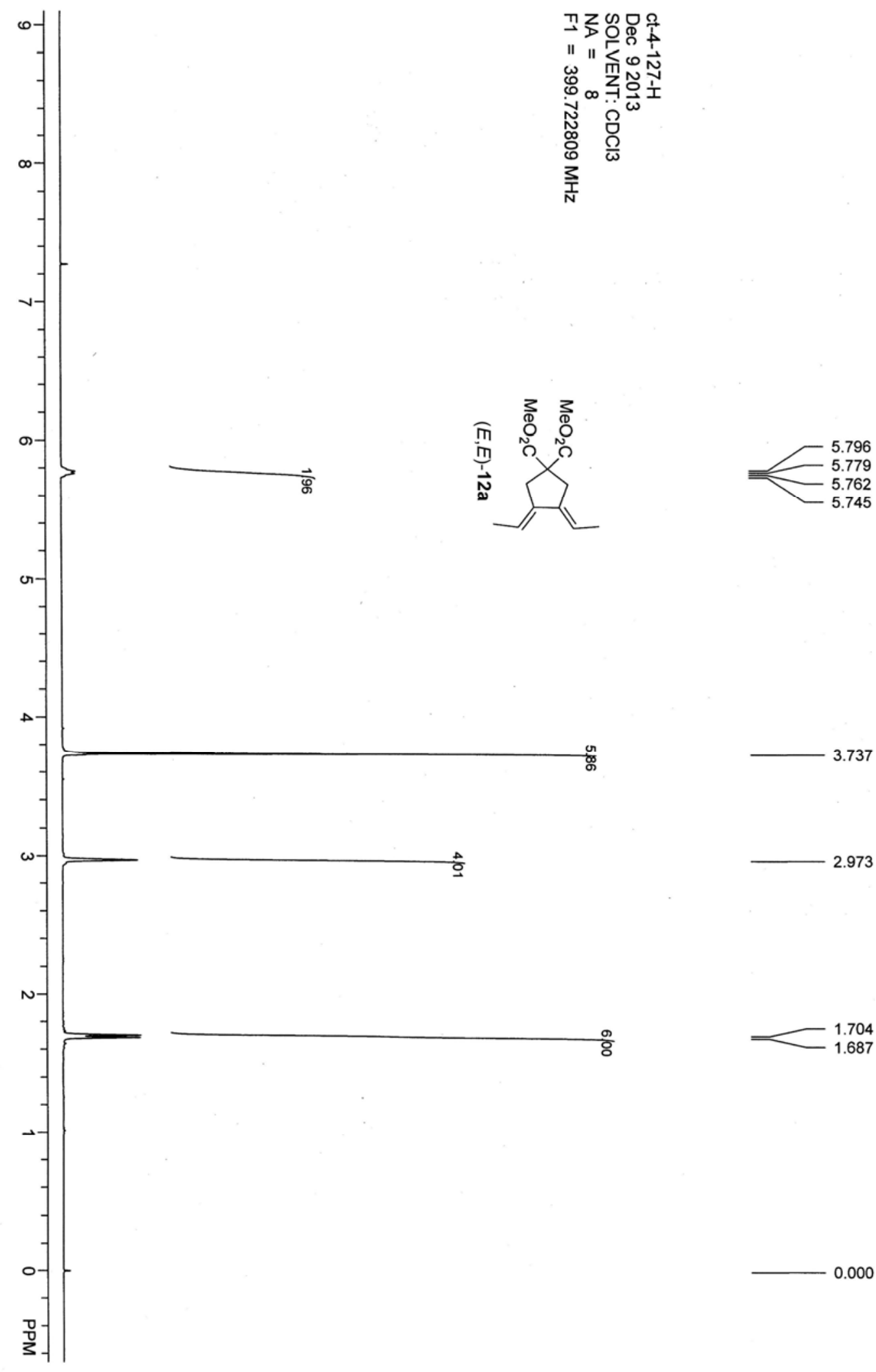

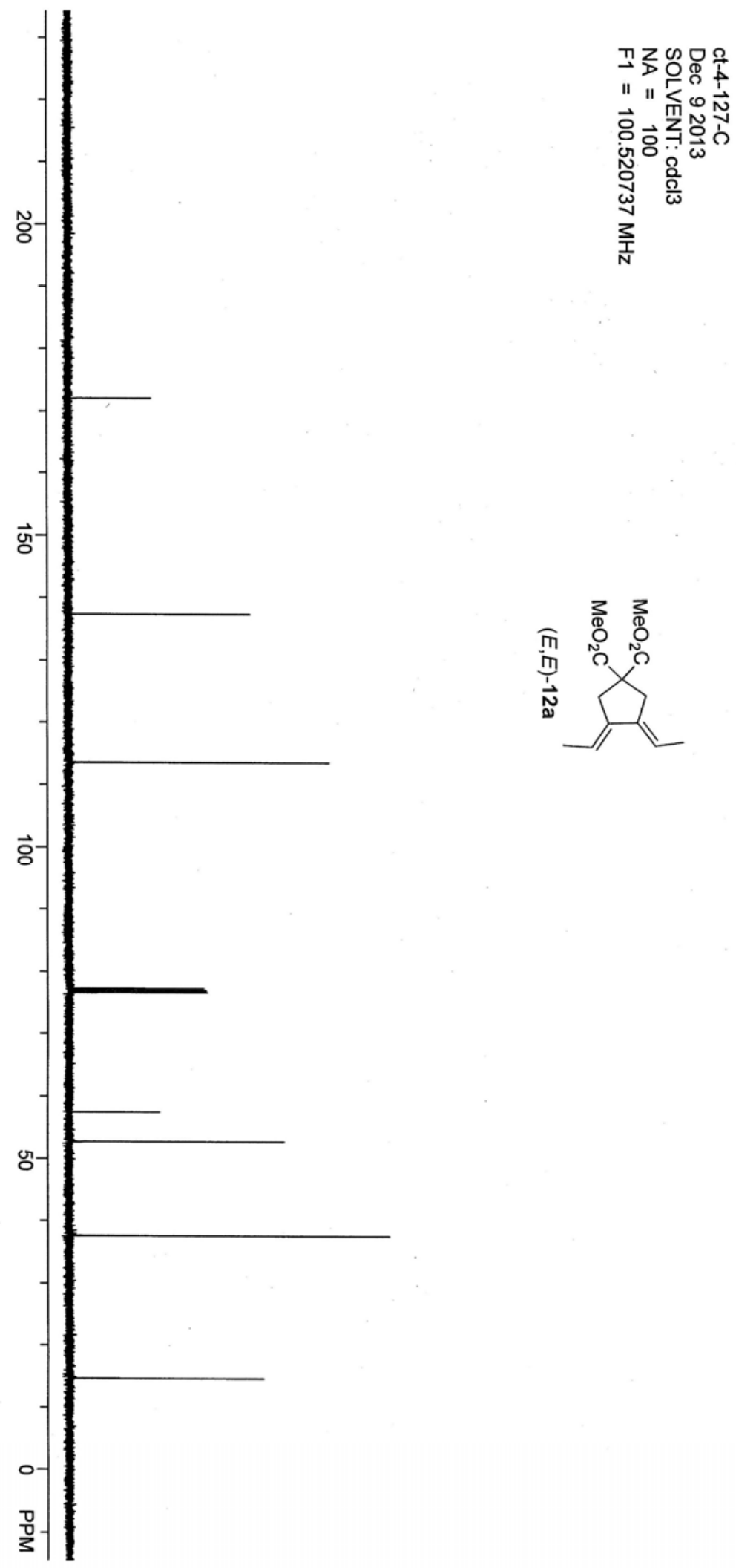

137.374
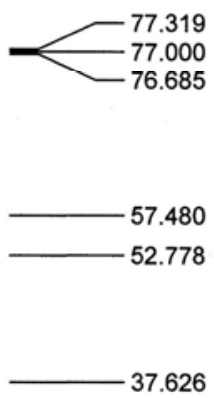

14.672 

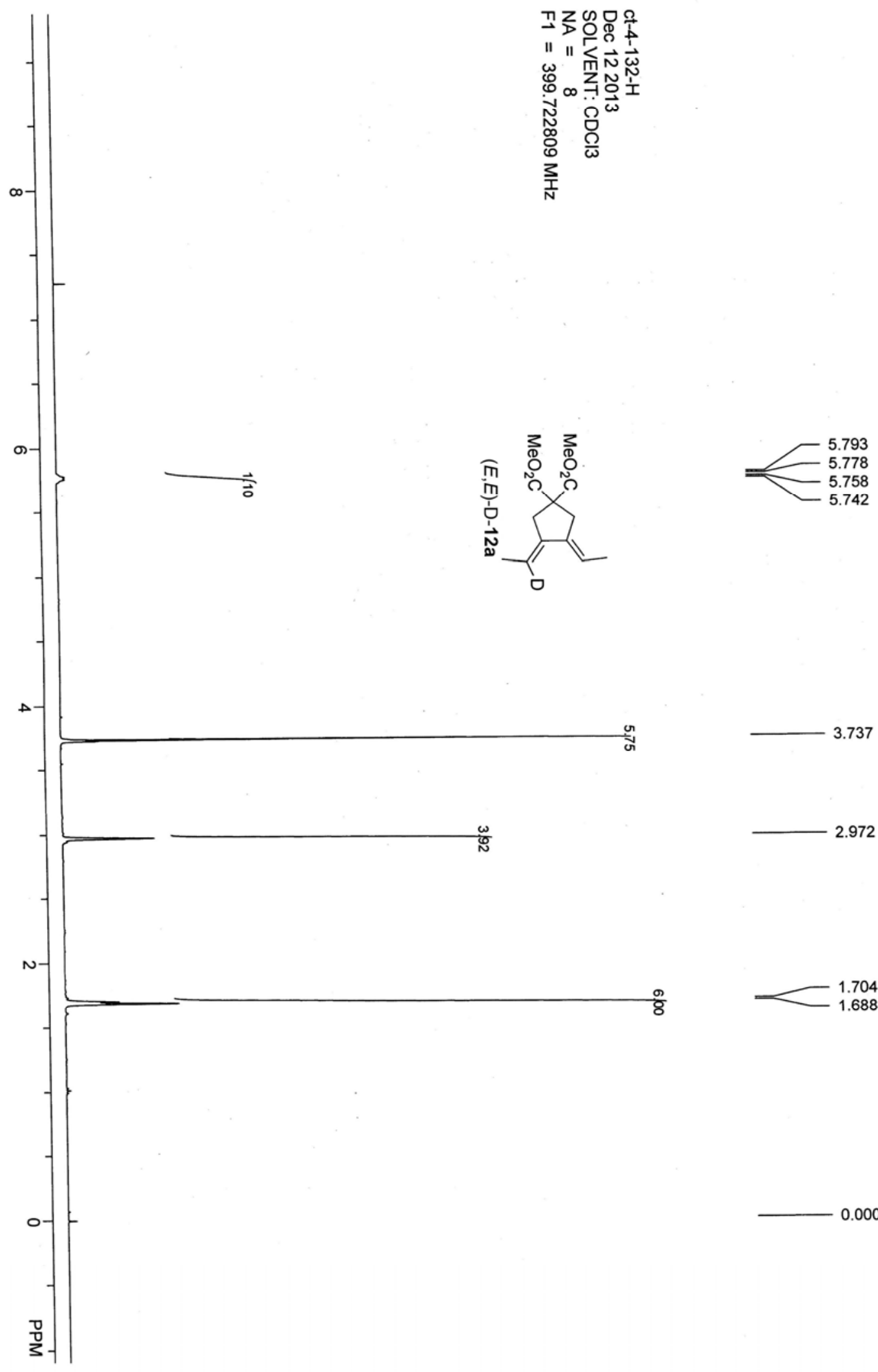

0.000 

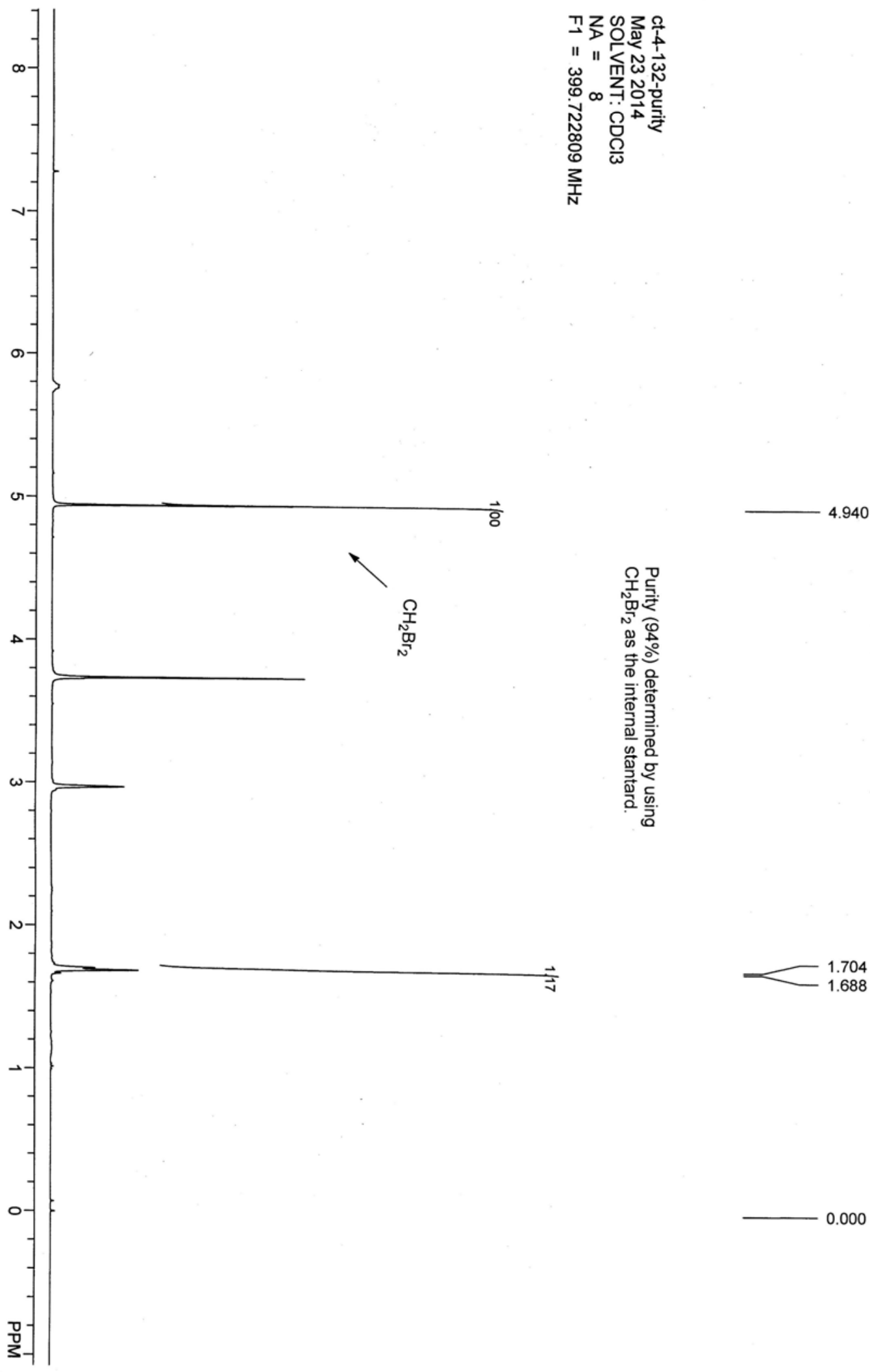


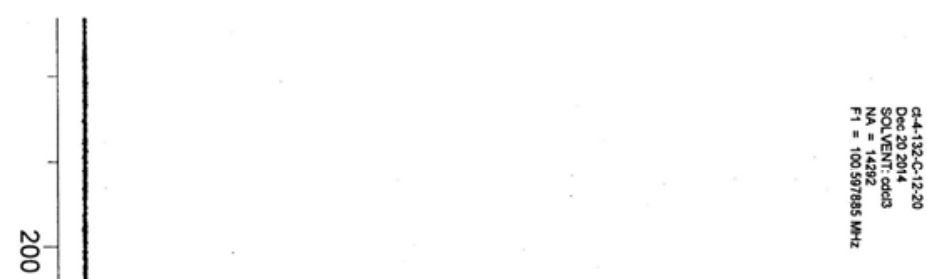

172.025

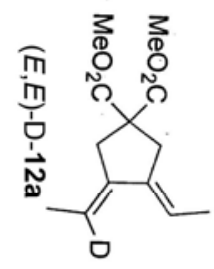

137.318
137.240

방

$\overrightarrow{\mathrm{o}}$

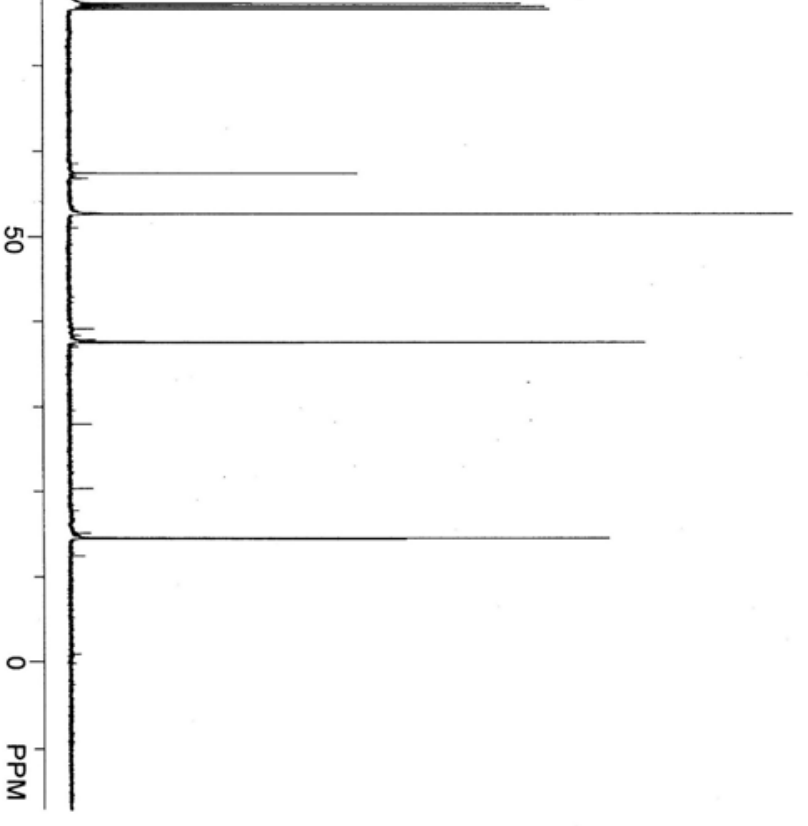

57.430

113.488 113.422 113.188

$-112.957$

77.000

$-76.683$

52.705
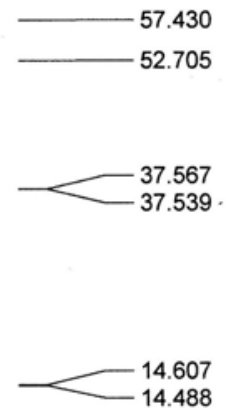


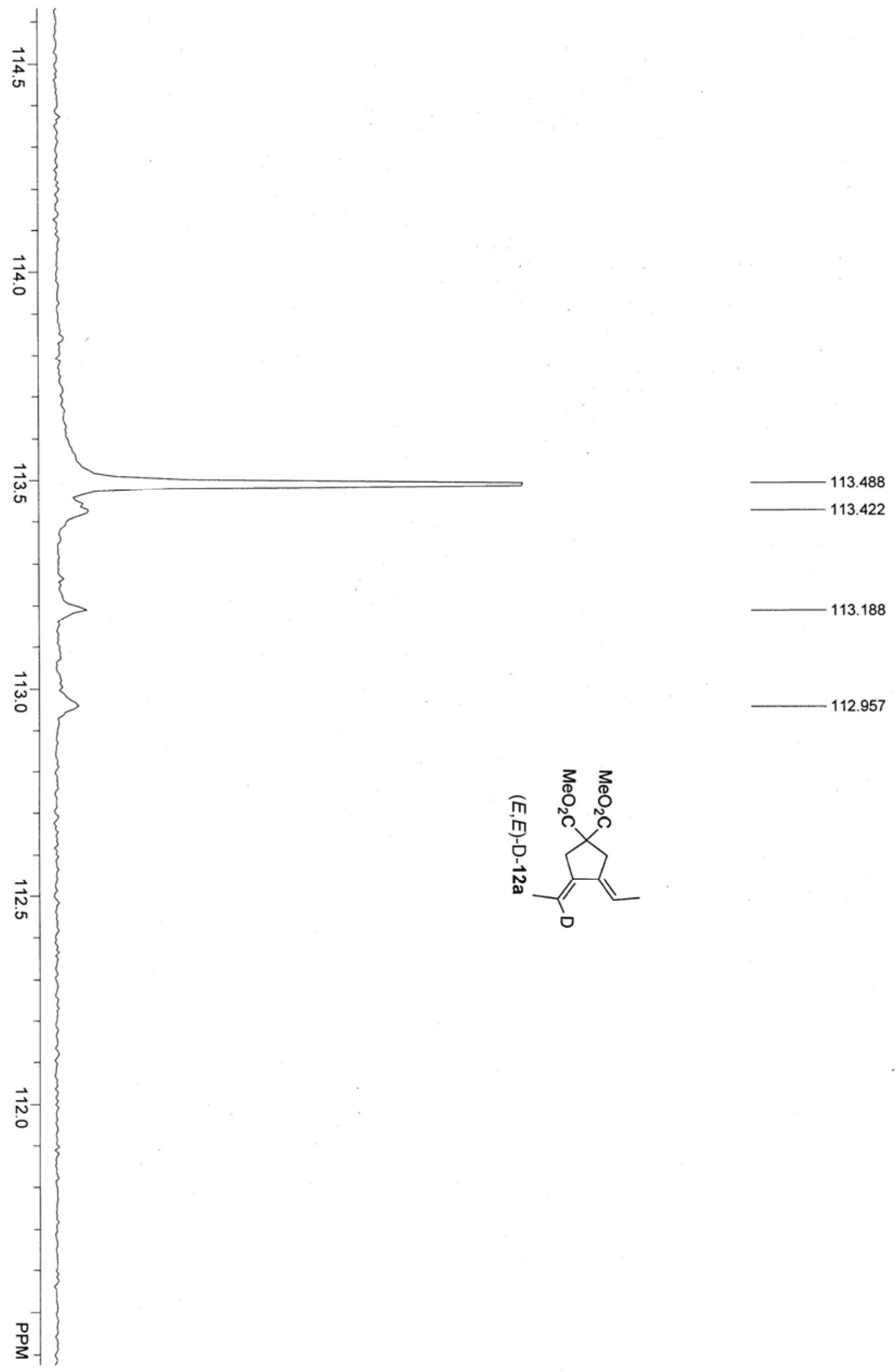

